\author{
UNIVERSIDADE FEDERAL DE JUIZ DE FORA \\ INSTITUTO DE CIÊNCIAS HUMANAS \\ PROGRAMA DE PÓS-GRADUAÇÃO EM CIÊNCIA DA RELIGIÃO
}

RONALD BELINASSI

A defesa das religiões de comunidades tradicionais de terreiro: os desafios da luta contra as formas de intolerância religiosa.

JUIZ DE FORA 


\title{
RONALD BELINASSI
}

A defesa das religiões de comunidades tradicionais de terreiro: os desafios da luta contra as formas de intolerância religiosa.

\author{
Dissertação apresentada como requisito para \\ mestrado em Ciência da Religião do Programa de \\ Pós-Graduação em Ciência da Religião, \\ Universidade Federal de Juiz de Fora.
}

Orientador: Prof. Sônia Regina Correa Lages

Juiz de Fora 


\section{Ronald Belinassi}

A defesa das religiões de comunidades tradicionais de terreiro: os desafios da luta contra as formas de intolerância religiosa.

Dissertação apresentada ao Curso de Ciência da Religião no Programa de Pós-Graduação em Ciência da Religião da Universidade Federal de Juiz de Fora (UFJF) como requisito parcial à obtenção do título de Mestre em Ciência da Religião. Área de concentração: Ciências Humanas.

Aprovada em 09 de março de 2021. 
Sônia Peguna Coviea bages

Profa. Dra. Sônia Regina Corrêa Lages - Orientadora

Universidade Federal de Juiz de Fora UFJF

Sônia Reguna Cariea bages

Profa. Dra. Zuleica Dantas Pereira Campos.

Universidade Católica de Pernambuco UNICAP

Sônia Peguna Coriea bages

Prof. Dr. Volney José Berkenbrock

Universidade Federal de Juiz de Fora UFJF 
Dedico este trabalho a todas e todos aqueles que lutam pelo respeito às religiões tradicionais de terreiro, que sofreram racismo religioso e que resistem na fé, contra os abusos daqueles que demonizam as formas tradicionais, e, caminham para demonstrar a grandeza de suas origens e a força das tradições religiosas, que já fazem parte da cultura e da diversidade religiosa no Brasil. 


\section{AGRADECIMENTOS}

Aos meus pais, Sebastiana Felipe e Emílio Belinassi Neto (in memoriam), que sempre acreditaram, me apoiaram, e fizeram críticas construtivas, dedico a vocês.

Às minhas irmãs Giselli e Mônica Belinassi e os irmãos Emílio Antônio, Welington, Wesley e Robson Belinassi, companheiras e companheiros de estrada.

À Sônia Lages, minha orientadora, que foi uma "mãezona" comigo, que acreditou em mim, teve paciência e sabedoria para guiar-me nesse trabalho.

Ao professores do departamento de Ciência da Religião da UFJF que me ensinaram a ver o fenômeno religioso como uma riqueza ímpar.

À minha esposa Sandrine Montes e aos meus filhos Isaac e Isadora, razões para minha dedicação à pesquisa.

A minha enteada Beatriz pela ajuda e a sua filha Maria recém-nascida.

À grande colaboradora e incentivadora Mônica Giraldo Hortegas.

A grande amiga e companheira e quase irmã Gislene Valério de Barros.

Aos colegas de trabalho das escolas do Estado e do Município aos quais leciono.

Aos colegas de mestrado e estudantes de Ciência da Religião da UFJF

À todas e todos os entrevistados que demostraram a força do axé, a luta pela liberdade religiosa e a resistência diante dos intolerantes.

Ao Dr. Hédio da Silva Júnior pela incansável defesa das religiões tradicionais de terreiro.

Ao Babalaô, Professor e Dr. Ivanir dos Santos pelas Caminhadas em defesa da liberdade religiosa.

In memoriam a todas e todos que faleceram devido aos desdobramentos da pandemia no Brasil e no Mundo. 
RESUMO:

A defesa das religiões de comunidades tradicionais de terreiro: os desafios da luta contra as formas de intolerância religiosa.

Em decorrência dos constantes relatos pela mídia nacional de ataques aos terreiros e aos praticantes das comunidades tradicionais de terreiro, o presente trabalho tem como objetivo analisar como o povo de santo vem resistindo ao processo de violência, isto é, à atuação de pessoas ou organizações ligadas às religiões de tradição de terreiros e as suas atitudes diante dos ataques intolerantes contra as religiões tradicionais de terreiro. Ou seja, verificaremos os processos de resistência do povo de santo aos atos violentos cometidos contra a sua fé. Sendo assim, nossa pesquisa buscou identificar, a partir da realização de entrevistas semiestruturadas e de forma qualitativa (com lideranças, assistências e frequentadores das respectivas religiões), a construção de uma resistência diante dos atos que reduzem a sua fé a sortilégios, charlatanismos ou, ainda, à pura demonização e aversão aos elementos que lembram ou remete para a fé, que, segundo os seus perseguidores, desviam as pessoas da "verdade". Através de análise das entrevistas, constatamos a existência de uma constante reação e inconformismo perante os ataques intolerantes, e de atitudes que sinalizam luta por justiça, por respeito à liberdade religiosa. Tais ações de resistência estão pautadas na força da fé das religiões tradicionais de terreiro e na constatação de que muitos dos ataques e da violência desses atos são resultado de uma das facetas do racismo à brasileira, ou seja, o racismo religioso.

Palavras-chave: Religiões tradicionais de terreiro, intolerância religiosa, guerra espiritual, racismo religioso, resistência. 


\section{ABSTRACT:}

The defense of the religions of traditional terreiro communities: the challenges of the fight against forms of religious intolerance.

Due to the constant reports by the national media of attacks on the terreiros and practitioners of the traditional terreiro communities, the present work aims to analyze how the people of santo have been resisting the process of violence, that is, the actions of people or organizations connected to traditional religions of terreiros and their attitudes towards intolerant attacks against traditional religions of terreiro. In other words, we will verify the processes of resistance of the holy people to violent acts committed against their faith. Thus, our research sought to identify, based on the realization of semi-structured interviews and in a qualitative way (with leaders, assistants and attendees of the respective religions), the construction of resistance in the face of acts that reduce their faith to charms, charlatanisms or, yet, to pure demonization and aversion to elements that resemble or refer to faith, which, according to their persecutors, lead people away from the "truth". Through the analysis of the interviews, we found the existence of a constant reaction and non-conformity in the face of intolerant attacks, and of attitudes that signal the struggle for justice, out of respect for religious freedom. Such resistance actions are based on the strength of the faith of the traditional terreiro religions and on the realization that many of the attacks and violence of these acts are the result of one of the facets of Brazilian racism, that is, religious racism.

Keywords: Traditional terreiro religions, religious intolerance, spiritual warfare, religious racism, resistance. 
Ficha catalográfica elaborada através do programa de geração automática da Biblioteca Universitária da UFJF, com os dados fornecidos pelo(a) autor(a)

\section{BELINASSI, RONALD.}

A defesa das religiões de comunidades tradicionais de terreiro : os desafios da luta contra as formas de intolerância religiosa. /RONALD BELINASSI. -- 2021.

$270 \mathrm{f}$.

Orientadora: Sônia Regina Corrêa Lages

Dissertação (mestrado acadêmico) - Universidade Federal de Juiz de Fora, Instituto de Ciências Humanas. Programa de Pós-Graduação em Ciência da Religião, 2021.

1. Religiões tradicionais de terreiro. 2. Intolerância religiosa. 3. Guerra espiritual. 4. Racismo religioso. 5. Resistência. I. Regina Corrêa Lages, Sônia, orient II. Título. 

11

1.1 PERCURSO METODOLÓGICO 15

1.2. PESQUISA QUALITATIVA 16

2.AS RELIGIOSIDADES AFRO-BRASILEIRAS E SUAS IDENTIDADES ...... 20

2.1. O QUE É IDENTIDADE? 20

2.2. AS IDENTIDADES AFRO-BRASILEIRAS 29

2.3. A QUESTÃO DA INTOLERÂNCIA RELIGIOSA COMO ATAQUE ÀS IDENTIDADES AFRO-BRASILEIRAS 56

2.4. O CANDOMBLÉ $\quad 71$

2.4.1. Os Orixás

2.5. VARIAÇÕES REGIONAIS NAS RELIGIÕES AFRO-BRASILEIRAS 79

2.6. A UMBANDA 82

2.6.1. O Kardecismo 91

2.6.2. A codificação umbandista 93

2.6.3. Organização burocrática e legitimação social da umbanda 95

2.6.4. As entidades "brasileiras" da umbanda 98

3.0 CONCEITO DE TOLERÂNCIA ….................................................... 100

3.1. AS BASES PSICOSSOCIAIS DA (IN)TOLERÂNCIA 143

3.1.1. A submissão à autoridade 143

3.1.2. A banalização do mal 144

3.1.3. Desvinculação entre o ato e suas consequências 144

3.1.4. Degradação da vítima 145

3.1.5. Processos de influência social 146

3.2. PRIVAÇÃO, MUDANÇA SOCIAL E INTOLERÂNCIA 150

4.INTOLERÂNCIA NO BRASIL CONTRA OS AFRO-RELIGIOSOS ............ 151

5.O RACISMO RELIGIOSO ................................................................ 198

6.OBSERVAÇÃO DO CAMPO RELIGIOSO E ENTREVISTAS .................... 235

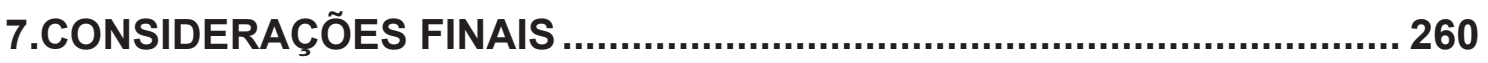

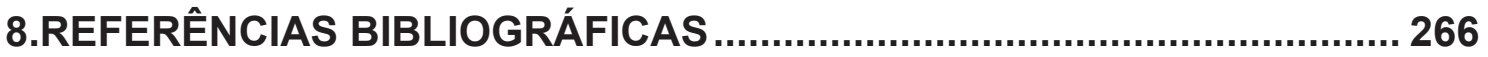

9.APÊNDICE A (Roteiro de Entrevistas) ….............................................. 270 


\section{INTRODUÇÃO}

A tarefa proposta é a questão da defesa das religiões de matriz africana contra os ataques intolerantes. A proposta tem como objetivo verificar a atuação de pessoas ligadas às religiões de matriz africana e quais as suas atitudes diante dos casos de intolerância religiosa: como se defendem, a quem recorrem e quais as respostas dadas pelos praticantes diante do contexto de "guerra religiosa" travada contra os fiéis das religiões afro-brasileiras.

A proposta requer uma análise sobre as religiões de matriz africana e o contexto de intolerância religiosa rotineira, iniciado após a evidência de expressões religiosas competitivas e motivadas pela Teologia da Batalha Espiritual, no campo religioso brasileiro, e o seu foco de livrar o Brasil das seitas não-cristãs.

O que realmente interessa é como os praticantes das religiões de matriz africana (ou o povo de santo) buscam se defender dos ataques intolerantes contra a sua fé, locais de cerimônia, símbolos e mesmo de agressões verbais ou físicas, motivadas pelo contexto de intolerância aos valores culturais aos quais remetem a fé nas religiões de matriz africana e aos objetos de religiosidade.

O cotidiano de intolerância, motivado pela explosão de casos e de problemas resolvidos durante as expressões religiosas de libertação, é um discurso utilizado para a eficiência e demonstração de poder dos neopentecostais, diante dos praticantes das religiões de matriz afro que, muitas vezes, são responsabilizados pelo surgimento de problemas relacionados às pessoas ou nas comunidades.

Essa busca pelo combate ao mal e aos seus praticantes é largamente utilizada pelas igrejas que utilizam da demonstração de poder de libertação e testemunhos. Quando acompanhava a minha mãe em visita a expressões religiosas de libertação, pude observar cura e expulsão de demônios e, até na atualidade, 
acompanho os programas televisivos que aludem aos problemas pessoais a ação dos demônios, discurso empregado com a ênfase em dramatizações comoventes e com muita competência e propriedade ao abordar os problemas, suas consequências e como esse ciclo de maldições pode ser quebrado.

A questão jurídica leva-nos a refletir sobre os impasses que ocorrem no interior da sociedade brasileira quando o tema é a questão da intolerância religiosa. Por que temos intolerância religiosa se, a princípio, vivemos e um Estado laico? Por que os praticantes das religiões de matriz africana são os que mais sofrem ataques intolerantes no Brasil?

Para obter essas respostas, necessitamos entender o histórico de lutas dos praticantes das religiões de matriz africana para a manutenção de suas raízes e da afirmação do povo negro como protagonista na construção da História do Brasil.

A desumanização do escravismo transformou-se em descaso com as populações negras e em repressão de suas crenças religiosas, desde os tempos do Brasil Colônia até os dias atuais. Antes, essa perseguição às religiões afrobrasileiras era praticada pelo Estado, que enviava as forças policiais para fechar terreiros e apreender objetos religiosos ou os praticantes que se encontravam no local. Hoje, a batalha espiritual travada por aqueles que perseguem o povo de santo chega ao extremo da expulsão de líderes religiosos, destruição de objetos dos terreiros e ataques pessoais aos praticantes com agressões verbais e físicas.

A temática da intolerância religiosa no Brasil foi abordada em um Relatório sobre Intolerância e Violência Religiosa no Brasil (2011 - 2015): Resultados Preliminares, publicado em 2016. O RIVIR estabelece o conceito de intolerância religiosa como 
Entende-se intolerância religiosa como crime de ódio que fere a liberdade e a dignidade humana, a violência e a perseguição por motivo religioso, são práticas de extrema gravidade e costumam ser caracterizadas pela ofensa, discriminação e até mesmo por atos que atentam à vida ${ }^{1}$.

A preocupação com o aumento de casos de intolerância religiosa no Brasil é evidenciada através deste documento, o RIVIR, e das constantes notícias veiculadas na imprensa brasileira. No caso das religiões de matriz africana é evidente o processo de perseguição religiosa do povo de santo.

Através deste trabalho será evidenciada a necessidade de analisarmos as apropriações dos conteúdos mágicos e rituais do campo afro-brasileiro pelos neopentecostais, principalmente a Igreja Universal do Reino de Deus (IURD), que busca demonstrar o poder na utilização desse repertório como símbolo da vitória de Cristo sobre os demônios.

Na primeira parte deste trabalho, faz-se necessário a apresentação de um percurso metodológico a respeito das motivações as quais levaram-me a empreender a pesquisa referente à resistência dos fiéis das religiões afro-brasileiras aos ataques intolerantes. Nesta parte, as explicações sobre o uso da pesquisa qualitativa; a relevância de estudar o campo afro-brasileiro, indo aos locais de religiões de matriz africana, e a utilização de um questionário, através do qual obteremos informações relevantes sobre a reação dos fiéis afro-brasileiros diante dos ataques intolerantes, são fundamentais.

No capítulo 2, apresentaremos a formação das religiões afro-brasileiras como um processo de afirmação da população africana, diante da imposição religiosa portuguesa e do trabalho forçado, como alternativa para aquele que chegava ao

\footnotetext{
1 Relatório sobre intolerância e violência religiosa no Brasil (2011-2015): resultados preliminares/Ministério das Mulheres, da Igualdade Racial, da Juventude e dos Direitos Humanos; organização, Alexandre Brasil Fonseca, Clara Jane Costa Adad. - Brasília: Secretaria Especial de Direitos Humanos, 2016. 146 p.: il. Color. $30 \mathrm{~cm}$. Página: 8.
} 
Brasil e tinha arrancado de si todas as oportunidades de viver dignamente. A alternativa à violência do sistema escravista e da falsa liberdade ao negro brasileiro após a Abolição era a proteção das comunidades de terreiros àqueles que foram entregues ao descaso e ao abandono.

No capítulo 3, elencaremos os conceitos de tolerância e de intolerância com os argumentos dos defensores da tolerância, John Locke (1983) e Voltaire (2008), e as razões para a intolerância religiosa ocorrer. A tolerância, em muitos casos, como será demonstrado, perpassa uma aceitação da diferença religiosa até o momento de demonstrar força e impor a religiosidade do mandatário, conforme os ditames da supremacia política e religiosa, desejada tanto pelos religiosos quanto pelos que anseiam por um poder totalitário e sem contestações.

Já no capítulo 4, trataremos das especificidades da intolerância contra as religiões afro-brasileiras: a abordagem desse contexto de atos intolerantes contra os afro-religiosos tem motivações na disputa pelo mercado religioso brasileiro. Mas o contexto da formação dessas religiões não foi de um estabelecimento de diversidade religiosa e sim de hegemonia da cristandade oficial do Estado brasileiro, que não aceitava a possibilidade do exercício de variações e adaptações da fé, promovendo o início de uma mentalidade demoníaca sobre o universo religioso afro-brasileiro.

Essa demonização extrapolou níveis abstratos e formou o que hoje conhecemos como atos intolerantes praticados contra o povo de terreiro, onde, no início da religiosidade, era o Estado o responsável pelas perseguições; hoje, atores denominados "cristãos fervorosos" praticam os atos intolerantes e buscam sistematizar um contexto de guerra religiosa e de batalha espiritual contra as forças malignas e seus seguidores. 
No capítulo 5, trataremos da especificidades dos ataques sofridos pelos afro religiosos e a constatação de desdobramentos do racismo contra aqueles que praticam as religiões tradicionais de terreiro, isto é, trata-se de um racismo religioso.

No capítulo 6, analisaremos a contribuição dos que lutam contra os atos intolerantes, ou seja, a reação dos seguidores das religiões de matriz africana diante dos atos intolerantes praticados por seus perseguidores. Faremos isso através de entrevistas e de questionários que buscam explicitar a opinião daqueles que defendem suas práticas religiosas contra as diversas formas de atos praticados pelos agentes que desejam subjugar e desconsiderar a contribuição das religiões de matriz africana na formação da religiosidade brasileira.

Enfim, por último, consideraremos que, sem a resistência das religiões de tradicionais de terreiro para a religiosidade dos brasileiros e até para o cotidiano do povo no Brasil, não teríamos muitos dos elementos que caracterizam a nossa cultura e identidade como nação, perderíamos a nossa essência nacional.

\subsection{PERCURSO METODOLÓGICO}

O interesse pela pesquisa surgiu a partir da realização de um curso de especialização em História e Cultura Africana e Afro-brasileira: educação para as relações étnico-raciais, promovido pela UFJF e Núcleo de Estudos Afro-brasileiros (NEAB), durante os anos de 2011 e 2012. Após uma visita a um terreiro de umbanda, na disciplina sobre religiões de matriz africana e afro-brasileira, no módulo sobre umbanda, ministrado pela professora Maria da Graça Floriano, percebi que havia um certo temor com relação às práticas e rituais de umbanda.

Sobre essa constatação visível e patente - pois o primeiro contato realizado com as religiões afro-brasileiras foi pelo livro do bispo da Igreja Universal do Reino 
de Deus (IURD) Edir Macedo e a sua obra Orixás, caboclos e guias: deuses ou demônios? observava as imagens, lia as legendas e achava absurdo o sacrifício de animais, a utilização do sangue e a raspagem do cabelo para a iniciação. Não foram utilizadas essas práticas nos rituais de umbanda.

No entanto, vi o uso do álcool e do fumo, o transe e até um momento em que ao meu lado estava um rapaz que passou por um transe, mas não tinha o controle e logo foi socorrido por ajudantes do terreiro. À medida em que a festa e as entidades se manifestavam, verificava que a utilização delas para a cura e a orientação eram visíveis e não uma utilização dos rituais para o chamamento e culto aos demônios.

A necessidade de trabalhar com essa temática partiu do interesse em cursar, na Especialização em Ciência da Religião, a disciplina Metodologia do Trabalho Científico com a questão da reação dos praticantes das religiões de matriz africana aos ataques intolerantes, promovendo o início da discussão do assunto, da escolha do orientador e de um levantamento bibliográfico inicial, o que resultou em um projeto que foi aprovado para o mestrado em Ciência da Religião.

\subsection{PESQUISA QUALITATIVA}

A opção pela pesquisa qualitativa resulta da necessidade de enquadrarmos os estudos sociais e os casos de ações de resistência aos ataques intolerantes como respostas de setores sociais, que demandam conhecimentos adquiridos do contato com esses elementos atuantes, em seus respectivos papéis de afirmação e ordenamento na sociedade em questão. Como afirmação sobre a necessidade de trabalhar com a pesquisa qualitativa e a sua aplicação nas Ciências Sociais destacamos

A pesquisa qualitativa responde a questões muito particulares. Ela se ocupa, nas Ciências Sociais, com um nível de realidade que não pode ou 
não deveria ser quantificado. Ou seja, ela trabalha com o universo dos significados, dos motivos, das aspirações, das crenças, dos valores e das atitudes. Esse conjunto de fenômenos humanos é entendido aqui como parte da realidade vivida e partilhada com seus semelhantes. O universo da produção humana que pode ser resumido no mundo das relações, das representações e da intencionalidade e é objeto da pesquisa qualitativa dificilmente pode ser traduzido em números e indicadores quantitativos (DESLANDES, 2013, p. 24).

A aplicação da pesquisa qualitativa aos fenômenos humanos está relacionada às atitudes reativas diante dos ataques intolerantes às religiões de matriz africana. objetivo do trabalho não é quantificar dados de reações aos ataques intolerantes, pelo contrário, ao buscar a opinião daqueles que sofreram ataques ou dos que atuaram na defesa dos fiéis das religiões afro-brasileiras em relação aos atos intolerantes contra a sua fé. Isso implica em um uso da pesquisa qualitativa como instrumento necessário para evidenciar a opinião dos querem reafirmar a sua crença, mesmo diante de um histórico de invisibilidade, discriminação, preconceito, ódio e até de uma demonização de suas respectivas manifestações religiosas provocados por um conjunto de atores que desejam limpar a nossa história da presença africana e afro-brasileira.

Para levar à academia as vozes resistentes aos ataques intolerantes, não existe alternativa de trabalho fora a de um ingresso ao campo afro-brasileiro e toda a sua maneira diferenciada de entender e viver de maneira integrada à natureza e a do respeito aos excluídos e perseguidos na sociedade racista brasileira. Devemos refletir sobre o trabalho de campo como uma aproximação entre observador e observado, mas sabendo que essa lógica pode ser invertida em diversos casos. Como observa

O trabalho de campo permite a aproximação do pesquisador da realidade sobre a qual formulou uma pergunta, mas também estabelecer uma interação com os "atores" que conformam a realidade e, assim, constrói um conhecimento empírico importantíssimo para quem faz pesquisa social. É claro que a riqueza desta etapa vai depender da qualidade da fase exploratória. Ou seja, depende da clareza da questão colocada, do 
levantamento bibliográfico bem feito que permita ao pesquisador partir do conhecimento já existente e não repetir o nível primário da "descoberta da pólvora", dos conceitos bem trabalhados que viabilizem sua operacionalização no campo e das hipóteses formuladas (DESLANDES, 2013, p. 75).

A proposta de ir à campo para garantir a visibilidade de atores sociais que sofreram e sofrem ataques intolerantes é um meio de garantir, aos que foram atingidos pelo aspecto intolerante, uma resposta diante do fenômeno da intolerância religiosa crescente no Brasil e, principalmente, contra os fiéis das religiões afrobrasileiras.

A intenção é demonstrar a força da fé afro-brasileira e a reação aos diversos ataques sofridos por amplos setores sociais - tanto os oficiais, no início da formação das comunidades tradicionais de terreiro afro-brasileiras, quanto na atualidade, quando, sob o disfarce de disputas por fiéis, grupos religiosos lançaram, através da Teologia da Batalha Espiritual, ataques constantes e objetivos às religiões de matriz africana.

Esses grupos reforçaram seus caixas com a constante dilapidação dos recursos financeiros dos fiéis com a questão da Teologia da Prosperidade, que diz que você, fiel, será rico pela graça de Deus e se pagar os dízimos e ofertas regularmente aos pastores. Estes estão sempre ávidos e se utilizam de recursos e estratégias que chegam a sofisticadas formas de exploração gerencial para incrementar exponencialmente o número de fiéis e as formas de arrecadar e de gerenciar os recursos arrecadados, formalizando empresas de comunicação, financeiras e tantos outros negócios para reforçar a Teologia da Prosperidade. Contudo, a principal forma de demonstração de força dos perseguidores das religiões de matriz africana está no campo político e na formação do Congresso 
Nacional, da Bancada da Bíblia e de diversos outros meandros do mundo político, chegando a colocar um presidente que se intitula evangélico.

A força da reação dos fiéis das religiões de matriz africana não se encontra na mesma estratégia usada pelos seus perseguidores, e sim na busca pela afirmação da liberdade religiosa e na defesa de seus locais de religiosidade e de ritos. $\mathrm{Na}$ justiça, tais reinvindicações chegaram até as instâncias máximas do judiciário brasileiro com o fim de preservar a fé nos orixás, voduns, inquices e entidades que representam muito mais do que expressão da fé, que já pertencem à cultura nacional e à memória dos brasileiros e brasileiras.

Ao expor a opinião daqueles que sofreram ou aos que defendem os que sofreram ataques intolerantes, não serão informados nomes ou circunstâncias que possam ferir ou prejudicar os entrevistados. Além disso, o interesse desta pesquisa foi submetido a um Comitê de Ética da Universidade Federal de Juiz de Fora, ao qual submeti o projeto e as perguntas aprovadas por este órgão para garantir a privacidade e o interesse daqueles que submeterem as questões.

O objetivo é levar ao campo acadêmico as estratégias de defesa que o povo de santo utiliza para se defender daqueles que desejam a destruição ou até mesmo a apropriação do repertório mágico como conquista e inutilização da fé dos fiéis afrobrasileiros em suas respectivas crenças.

A importância da entrevista para demonstrar a opinião daqueles que estão reagindo aos ataques dos intolerantes religiosos é justificada pela profundidade da ferramenta utilizada na pesquisa, além da importância de garantir a autonomia e contribuir com o debate sobre o problema da intolerância religiosa contra os afroreligiosos e suas demandas por justiça e respeito pela fé de matriz africana. 
A entrevista é um recurso poderoso para dar dignidade e incluir atores sociais que, devido aos ataques intolerantes sofridos, poderiam simplesmente não relatar absolutamente nada para não reviver problemas aos quais passaram e que dificilmente desejariam recordar ou mesmo dar crédito aos seus detratores e perseguidores.

Como uma técnica de comunicação, a entrevista pode ser utilizada de acordo com o espaço a se investigar e o grupo com o qual se quer trabalhar. Surge a necessidade de investigar o campo com o qual se quer trabalhar e, daí, realizar as pesquisas em forma de entrevistas defendida por Deslandes:

\begin{abstract}
Entrevista, tomada no sentido amplo da comunicação verbal, e no sentido restrito de coleta de informações sobre determinado tema científico, é a estratégia mais usada no processo de trabalho de campo. Entrevista é acima de tudo uma conversa a dois, ou entre vários interlocutores, realizada por iniciativa do entrevistador. Ela tem o objetivo de construir informações, pertinentes para um projeto de pesquisa e abordagem pelo entrevistador, de temas igualmente pertinentes com vistas a este objetivo. As entrevistas podem ser consideradas conversas com finalidade e se caracterizam pela sua forma de organização (DESLANDES, 2013, p. 79).
\end{abstract}

As entrevistas apresentam classificações, de acordo com Minayo. No entanto, a opção escolhida na classificação dos tipos de entrevistas foi a "semiestruturada, que combina perguntas fechadas e abertas, em que o entrevistado tem a possibilidade de discorrer sobre o tema em questão sem se prender a indagação formulada".

\title{
2. AS RELIGIOSIDADES AFRO-BRASILEIRAS E SUAS IDENTIDADES
}

\subsection{O QUE É IDENTIDADE?}

Quem é você? Quem sou eu? Geralmente, quando realizamos perguntas como as anteriores, estamos em busca da nossa identidade. Ao respondermos, o que pode ser fácil ou não, estamos mostrando aos outros quem somos nós e, é 
claro, nos reconhecendo, ou tentando mostrar o que buscamos demonstrar aos demais interessados na sua identidade. Haverá certeza ou não do que buscamos oferecer como identidade aberta ou, ainda, o que ocultamos dos demais para que eles não percebam exatamente quem somos.

A identidade, em muitos casos, é a descrição de uma personagem. De acordo com Ciampa (LANE \& CODO,1994, p. 60) "Todos nós - eu, você, as pessoas com quem convivemos - somos as personagens de uma história que nós mesmos criamos, fazendo-nos autores e personagens ao mesmo tempo".

A trama das personagens é um jogo de ocultação, mas que pode levar a revelações, dependendo daquilo que queremos ocultar, mas acabamos revelando.

A questão de buscar informações é algo comum, ou seja, todos buscam fontes confiáveis de informações sobre algo ou alguém, isto é, as referências nas quais busca-se analisar e interpretar os dados obtidos. Cremos que com os dados obtidos possam revelar-nos a verdade.

O nome é a forma inicial de obtenção de informações. Nosso nome é a nossa identificação e a nossa singularidade. O nome pode nos diferenciar ou nos igualar neste caso, o uso do sobrenome identifica a família ao qual pertencemos

O conhecimento de si é dado pelo reconhecimento recíproco dos indivíduos identificados através de um determinado grupo social que existe objetivamente, com sua história, suas tradições, suas normas, seus interesses etc. (LANE; CODO, 1994, p. 64).

Refletindo sobre nossa identidade, devemos considerar os grupos aos quais pertencemos e como agimos de acordo com os grupos, isto é, vamos nos diferenciando e nos igualando. Temos os grupos como nestes exemplos: os homens e as mulheres, os brasileiros e os estrangeiros, no caso que estudamos, os cristãos e os não-cristãos, dentro desses não-cristãos, os que tem a sua fé nas religiões de 
matriz africana. Enfim, "nós somos nossas ações, nós nos fazemos pela prática", como afirma Ciampa.

Ao responder à pergunta "quem sou eu?", geralmente, a tendência é uma resposta visando um aspecto representacional da noção de identidade. No entanto, ao responder dessa maneira vaga é deixado de lado o aspecto constitutivo, o de produção e, é claro, as implicações de reciprocidade entre os aspectos.

Assim, Ciampa (1994, p. 65) esclarece que a representação é o nosso ponto de partida, "considerando-a também como processo de produção, de tal forma que a identidade passe a ser entendida como o próprio processo de identificação".

Para vislumbrar a identidade como fenômeno social, Ciampa esclarece que isso é aceitável pelos cientistas sociais. O estabelecimento de uma distinção entre o objeto de nossa representação e a sua representação, ambos serão apresentados como fenômenos sociais, resultando em objetos sem características de permanência, não sendo independentes um do outro, conforme Ciampa.

Não é possível deixar de lado um conjunto de elementos (biológicos, psicológicos, sociais etc.), que caracterizam o indivíduo, identificando e, do outro modo, representar o indivíduo como uma duplicação mental ou simbólica, expressando a sua identidade, de acordo com Ciampa. Ocorre uma interpenetração desses dois aspectos e, ainda, conforme o autor, "a individualidade dada já pressupõe um processo anterior de representação que faz parte da constituição do indivíduo representado".

De uma relação paterno-filial, temos a identificação inicial, ou seja, a identidade do filho é consequência de uma anterioridade que condiciona essas relações. Através da explicação de Ciampa temos uma complexidade a ser considerada 
Uma vez que a identidade pressuposta é reposta, ela é vista como dada - e não como se dando num contínuo processo de identificação. É como se uma vez identificada a pessoa, a produção de sua identidade se esgotasse com o produto. Na linguagem corrente dizemos "eu sou filho"; dificilmente alguém dirá "estou sendo filho (LANE; CODO, 1994, p. 66).

Ele ainda afirma a respeito da temporalidade ou não da identidade

A posição de mim (o eu ser-posto) me identifica, discriminando-me como
dotado de certos atributos que me dão uma identidade considerada
formalmente como atemporal (LANE; CODO, 1994, p. 66).

Temos uma multiplicidade de papéis a cumprir que acabam por nos identificar.

No entanto, o que determina é como compareço frente aos outros como representante de mim. Assim conclui o autor: “(...) as identidades, no seu conjunto, refletem a estrutura social ao mesmo tempo que reagem sobre ela conservando-a ou a transformando".

A identidade é um passo importante na história do homem, isto é, o identificarse ou buscar uma identificação é um dado e não um dar-se que expressa um movimento social. O movimento social é a história. A história é a hominização do homem. O homem, neste caso, é um ser de possibilidades, sua essência histórica. O homem participa de uma substância humana, que se realiza como história e como sociedade, nunca como indivíduo isolado, sempre como humanidade. Contendo uma infinidade de humanidade, o homem busca a realização material no tempo e ocupando espaços, isto é, os instantes da existência de cada indivíduo visa uma concretização da totalidade, na qual ela é negada e determinada, socialmente, como parte; e o autor, resume, que: "assim, eu existo como negação de mim-mesmo, ao mesmo tempo que o que estou-sendo sou eu-mesmo."

Sendo parcela de minha humanidade, isso fornecerá ao indivíduo uma identidade que nega aquilo que sou sem estar-sendo (a minha humanidade total). Neste caso, Ciampa considera que 


\begin{abstract}
Essa identidade que surge como representação de meu estar sendo se converte num pressuposto de meu ser (como totalidade), o que, formalmente, transforma minha identidade concreta (entendida como um dar-se numa sucessão temporal) em identidade abstrata, num dado atemporal - sempre presente (entendida como identidade pressuposta reposta) (LANE; CODO, 1994, p. 69).
\end{abstract}

Estamos diante dos outros como representação e de acordo com o autor isto ocorre de três formas:

1) Representante de mim;

2) Desempenhando papéis;

3) Reitero a apresentação de mim.

Ora, também podemos representar os outros e essa expressão do "outro" que também sou eu, consiste na "alterização" da minha identidade, na identidade pressuposta e no desenvolvimento de um ser em processo ou uma metamorfose.

O homem do vir-a-ser não pode ser confundido com uma semente. Nem, muito menos, está liberado de suas condições históricas, ou seja, não é possível dissociar o estudo da identidade do indivíduo do da sociedade.

Não devemos confundir etapas históricas, ou seja, o estudo da questão da identidade é colocado de maneira diferente em diferentes sociedades. O homem não está dissociado da sociedade, essa dissociação é o problema do homem moderno.

A questão da identidade e a sua busca remete-nos a um projeto político. Tal projeto deve incluir a questão da identidade do homem na nossa sociedade, a necessidade de uma construção coletiva e democrática perpassa a capacidade racional de uma construção consciente e realizada por todos nós.

Os entraves para essa transformação estão no intelectualismo desnecessário que leva a um imobilismo e, de um outro lado, a concepção de identidade como permanência e estabilidade patologizando a mudança e a transformação. 
A identidade é movimento, é transformação, é metamorfose, enfim, é uma infindável transformação, ou seja, é sermos um em um outro, para chegarmos a ser um.

$\mathrm{Na}$ introdução do texto de Woodward, há um exemplo de luta atual de identidades no conflito nacionalista extremado e divisionista do que restou da antiga lugoslávia elaborada pelo escritor e radialista Michael Ignatieff.

A história sobre o conflito dos Balcãs, no final do século passado, é, também, uma história sobre identidades. No caso, identidades diferentes, a dos sérvios e a dos croatas. Esses povos viveram juntos por cinquenta anos sob o regime de Tito, na lugoslávia. Pelo relato identificado por Ignatieff, o miliciano sérvio queixa-se de que os croatas pensam que são melhores que os sérvios e conclui: "Somos todos lixos dos Balcãs" (SILVA, 2000, p. 8).

O desenrolar dessa história mostra que essas identidades são marcadas pelas diferenças e da negação de sérvios pelos croatas e vice-versa. Assim, sustentada pela exclusão, isto é, ao afirmar que os croatas se achavam europeus finos, o miliciano sérvio inferiorizava-se. No entanto, ele iguala todos os ocupantes dos Balcãs como inferiores aos demais europeus.

Como observou Woodward (2000, p. 10): “(..), a construção da identidade é tanto simbólica quanto social." A autora também destaca diferentes identidades têm por base a história e a produção de novas identidades, por sérvios e croatas perpassam uma redescoberta de valores do passado, ou seja, a reprodução desse passado glorioso em momentos de crise e, obviamente, de uma redescoberta do passado como parte de construção da identidade. 
Essa discussão sobre identidade tem uma tensão entre perspectivas essencialistas e perspectivas não essencialistas. A autora define sobre essas questões relacionadas a identidade sérvia

Uma definição essencialista da identidade 'sérvia' sugeriria que existe um
conjunto cristalino, autêntico, de características que todos os sérvios
partilham e que não se altera ao longo do tempo. Uma definição não-
essencialista focalizaria as diferenças, assim como as características
comuns e partilhadas, tanto entre os próprios sérvios quanto entre os
sérvios e outros grupos étnicos. Uma definição não essencialista prestaria
atenção também as formas pelas quais a definição daquilo que significa ser
um 'sérvio' têm mudado ao longo dos séculos (SILVA, 2000, p.12).

As questões a serem analisadas pela autora neste capítulo são:

1. Conceitualizações para compreender como a identidade funciona;

2. Em muitos casos a identidade reivindica essencialismos sobre o pertencimento ou não de um determinado grupo identitário, nas quais a identidade é taxada como fixa ou imutável.

3. Algumas dessas reivindicações estão baseadas na natureza, neste caso, a versões de identidade étnica, na questão da 'raça' e relações de parentesco. No entanto, essas reivindicações têm como base uma versão essencialista, um passado glorioso de representação imutável.

4. A identidade é relacional e a diferença é apresentada por uma marcação simbólica com relação a outras identidades, isto é, no caso de afirmação de identidades nacionais, por exemplo, o uso de uniformes, a bandeira nacional ou mesmo os hábitos ou vícios.

5. A identidade está vinculada a condições materiais e sociais. Neste caso, um grupo rotulado como inimigo ou tabu, proporcionará ao grupo em questão exclusão e desvantagens materiais. 
6. O social e o simbólico, são dois processos diferentes, mas eles ajudam na construção e na manutenção das identidades. Como é esclarecido a marcação simbólica e diferenciação social por Woordward:

A marcação simbólica é o meio pelo qual damos sentido a práticas e a relações sociais, definindo, por exemplo, quem é excluído e quem é incluído. É por meio da diferenciação social que essas classificações da diferença são 'vividas' nas relações sociais (SILVA, 2000, p.124).

7. Ao conceitualizar identidade devemos examinar os sistemas classificatórios que mostram como as relações sociais são organizadas e divididas, isto é, dois grupos em oposição, o "nós e eles".

8. As diferenças podem ser marcadas e outras obscurecidas, isto é, ao afirmar a identidade nacional as diferenças de classe e de gênero são omitidas.

9. As identidades não são unificadas. Há contradições para serem negociadas. Ocorrem discordâncias entre o nível coletivo e o nível individual.

10. As pessoas assumem suas posições de identidade e se identificam com elas. Para Woodward, o nível psíquico deve entrar na explicação da formação da identidade, assim como, o simbólico e o social.

O corpo estabelece as fronteiras que definem quem somos nós, isto é, é a base biológica e a forma essencial da identidade. Entretanto, os movimentos étnicos ou religiosos ou nacionalistas reivindicam na base cultural ou de uma história comum o fundamento de sua respectiva identidade.

A identidade é um conceito central, isto é, no plano global, as preocupações centrais são com identidades nacionais e as identidades étnicas; nas questões 
locais preocupam-se com a identidade pessoal e, sendo mais específico, relações pessoais e política sexual.

Para entender a questão da representação, a autora cita Hall, que diz que para se analisar os sistemas de representação é necessário analisar a relação entre cultura e significado. A abordagem de um "circuito da cultura", que expõem sistemas de representação para as identidades produzidas pelos sistemas. A representação engloba práticas de significação e os sistemas simbólicos, na qual os significados são produzidos, proporcionando a posição deles como sujeito. A autora enfatiza

É por meio dos significados produzidos pelas representações que damos sentido à nossa experiência e àquilo que somos. Podemos inclusive sugerir que esses sistemas simbólicos tornam possível aquilo que somos e aquilo no qual podemos nos tornar (SILVA, 2000, p.17).

A representação, inserida no processo cultural fornece identidades individuais e coletivas. No caso dos sistemas simbólicos, eles possibilitam o fornecimento de respostas às questões centrais dos indivíduos. A utilidade dos discursos e dos sistemas de representação para os indivíduos estão nas possibilidades de se posicionar e de determinar atos de discursos com produção de sentidos.

A mídia, através dos anúncios eficazes, traz imagens de identificação para o consumidor, desde que essas imagens produzam significados e identidades. Em suma, o foco é a representação para as identidades.

Os Estudos Culturais, principalmente a teoria do cinema, têm focado no conceito de identificação. Conceito este que origina na psicanálise, que consiste no processo de identificação com os outros, quer seja pela ausência de uma consciência da diferença ou da separação ou por similitudes. A produção de significados perpassa relações de poder, peculiarmente, a decisão de incluir ou de excluir. Enfim, a cultura molda identidades pelas suas subjetividades. Essa gama de 
sistemas simbólicos expõem as divisões e as desigualdades, reforçando os estigmas e exclusões. Essa questão demonstra o poder da cultura para reforçar estigmas e padrões de exclusão nas mãos de pessoas que, na maioria das vezes, reforçam desigualdades e demonizam setores historicamente excluídos. As religiões de matriz africana têm a força da cultura a seu favor, mas e quando essa cultura sofre a pecha de cultura inferior ou ligada às forças das trevas?

A sociedade brasileira sofre um processo de estigmatização do diferente e de uma verdadeira perseguição ao que não é considerado padrão ou aceito pela maioria do povo.

Os ataques intolerantes, apesar de serem denunciados e evidenciados pela imprensa nacional ou local, não há um esforço da mídia nacional para a retirada do estigma de religiões demoníacas ou de religiões inferiores e, ainda, de aproveitadores. Programas televisivos para alertar a população das consequências de atos intolerantes, ocorrem com escassez, diante da gravidade e da frequência dos ataques aos afro-religiosos.

\subsection{AS IDENTIDADES AFRO-BRASILEIRAS}

De acordo com Prandi (2000), entre os séculos XVI e XIX, foram trazidos mais de cinco milhões de africanos para o Brasil na condição de escravos. devido ao escambo, isto é, o cativeiro era uma prática comum aos africanos, bem antes da exploração colonial do Novo Mundo. Portanto, o tráfico de africanos para o outro lado do Atlântico proporcionava enorme lucratividade para os traficantes, que trocavam mercadorias originárias das Américas (tabaco, aguardente etc.) por

africanos capturados nas guerras e na caça praticada pelos próprios africanos e incentivadas pelos europeus. Para Prandi: "Os povos da África Negra são 
classificados, grosso modo, em dois grandes grupos linguísticos: sudaneses e bantos" (PRANDI, 2000, p. 53).

A chegada desses grupos ao Brasil foi organizada da seguinte forma

Nos primeiros séculos do tráfico, chegaram ao Brasil preferencialmente africanos bantos, seguidos mais tarde pelos sudaneses, cujo tráfico acentuou a partir da queda do império de Oió, destruído pelos fons do Daomé e depois dominados pelos haussás (PRANDI, 2000, p. 54).

A necessidade econômica do Brasil Colônia determinava a finalidade do uso da mão de obra escrava:

Assim, até a metade do século XVIII, grande parte da população negra importada destina-se aos engenhos de açúcar de Pernambuco e da Bahia, mas, com a descoberta do ouro em Minas, no século XVIII, há um deslocamento do tráfico para as Minas Gerais, correspondendo ao chamado Ciclo do Ouro. (PRANDI, 2000, p. 55).

O crescimento das cidades oportunizou mudanças significativas no trabalho escravo, ou seja, aumentaram as formas de arrecadação com os trabalhos desempenhados por escravos nas cidades. Como demonstra:

À medida que cresciam as cidades, sobretudo as litorâneas, já na virada para o século XIX, desenvolveu-se um mercado de serviços urbanos desempenhando pelos africanos escravos e baseado numa nova forma de espoliação, em que os escravos ofereciam suas habilidades profissionais a quem delas precisava, recebendo pagamento em dinheiro, destinado ao senhor do escravo, no todo ou em grande parte (PRANDI, 2000, p. 55).

De acordo com Prandi (2000), os denominados "escravos de ganho", juntamente como os "emancipados" e "africanos trazidos pelo tráfico ilegal, libertados pelo governo e por ele empregados (CONRAD, 1985, p. 171/186), ou seja, a escravidão não se restringia ao mundo rural ou nas áreas de extração de metais preciosos, ela encontrava-se, agora, nas cidades, onde ocorreram mudanças significativas com uma maior dinamização e diversificação das atividades relacionadas ao escravo no Brasil Colônia. 
A questão do negro e a sua identidade é lembrada por Prandi (2000) como uma forma de apagamento de suas raízes africanas

Uma vez em terras brasileiras, a própria política oficial da Coroa, em certos períodos, propiciava o apagamento das origens culturais, não estimulando, com o receio de sublevação, o agrupamento de escravos de mesmas origens, embora em outras épocas buscasse agregá-los para melhor os controlar (PRANDI, 2000, p. 56).

A diferença desta regra da política oficial da Coroa estava nas grandes cidades, como destaca

Nas grandes cidades, onde predominam africanos de importação mais recente, especialmente tratando-se de escravos de ganho que viviam aglomerados em habitações coletivas, havia a tendência dos negros, fossem eles libertos ou escravos, de se agregarem em função de suas etnias ou nações, vivendo com seus parentes, agregados e também seus escravos, estes em geral da mesma nação do senhor negro. O estudo "Viver e morrer no Meio dos Seus" de Maria Inês de Oliveira, sobre Salvador no século XIX, mostra exatamente isso (PRANDI, 2000, p. 56).

A assimilação do negro à cultura brasileira é notada quando

\begin{abstract}
Entre os africanos nascidos no Brasil há mais tempo, entretanto, já poucos falavam sua língua e mantinham costumes originais. No interior e nas cidades para onde a importação de africanos era mais antiga, menos vestígios culturais permaneciam intocados. Os casamentos entre nações, a miscigenação com o branco e com o índio, a adoção da cultura nacional promoveram com intensidade o apagamento das diferentes culturas africanas. Quanto mais distante do tempo estamos, mais intenso terá sido o processo de absorção do africano à cultura brasileira em formação, menos marcas culturais específicas terão sobrado (PRANDI, 2000, p. 56).
\end{abstract}

Ao analisar o fim do tráfico africano (1850) e a força de um novo produto impulsionador da economia, o café, Prandi considera que essas mudanças promoveram um rendoso mercado interno de escravos, vindos de áreas econômicas em declínio e adquiridos pelo novo mercado dos plantadores de café. E conclui que o rearranjo geográfico transforma a situação do negro no Brasil, que vai ficando distante da África e mais perto do Brasil.

Ao utilizar os argumentos de Bastide sobre a formação das nações, Prandi (2000) considera que o governo colonial fomentava essa estratégia no intuito de 
dividir para reinar, pois as conspirações foram denunciadas de antemão aos senhores pelos escravos de outras etnias.

Prandi (2000) relata mais sobre a formação das nações, citando Bastide, no qual:

Enfim, organizavam-se em associações de lazer, de ajuda mútua, mantendo casas nos subúrbios, onde se escondiam as cerimônias religiosas propriamente africanas e onde se preparavam as revoltas (BASTIDE, 1974, p. 13).

O fim da escravidão traz para a população negra o desafio da incorporação à sociedade brasileira, deixando as suas raízes para trás. Prandi (2000) busca explicar esse contexto através dos estudos de Bastide, no qual as referências das nações dos africanos caíram em desuso. Os negros generalizados como o tipo "negro", sem incorporar suas raízes. No entanto, as nações foram preservadas, de acordo com Prandi, como tradições culturais, candomblé no Brasil, santeria em Cuba e vodus no Haiti.

A cultura africana sofre um processo de diluição na formação da cultura nacional, que de acordo com Prandi (2000), abrangendo: língua, culinária, música, artes, valores sociais, representações míticas e religiosidade. Excetuando, a questão da religiosidade, as instituições africanas passaram por um processo de apagamento étnico e um rótulo de africano, sem dar conta das especificidades e das diferenças. Prandi afirma que:

\footnotetext{
Em outras palavras, a preservação daquilo que é africano requeria apagar ou disfarçar exatamente a origem e a marca negra, num processo de branqueamento que atingiu todas as áreas, do qual a umbanda é o exemplo emblemático, e que somente foi limitadamente revertido a partir dos anos 60 , quando a diferença, o pluralismo cultural e a valorização das origens étnicas passaram a constituir a orientação dos produtores e consumidores culturais, num movimento de âmbito cultural que foi bastante expressivo no Brasil (PRANDI, 2000, p. 59).
} 
A reconstituição cultural mais bem-acabada do negro no Brasil, segundo Prandi, foi a religião afro-brasileira com a capacidade de preservar-se até os dias de hoje. O contexto histórico dessa possibilidade de formação da religião afro-brasileira foi por volta da metade do século XIX, quando escravos, negros libertos e descendentes viviam em cidades o que proporcionou mudanças significativas como integração, liberdade de movimento, capacidade de organização e contato com tradições e culturas recentes face a leva de sudaneses ao Brasil.

A religião negra, segundo Prandi (2000), possui vários nomes, ou seja, na Bahia se chamou candomblé; em Pernambuco e Alagoas, xangô; no Maranhão, tambor-de-mina e, no Rio Grande do Sul, batuque, e foi organizada em grupos de "nações", ou "nações de candomblé".

Prandi (2000) aponta as vertentes dos candomblés da Bahia: ketu, ijexá e efã, todos de origem nagô ou iorubá; o candomblé de culto aos ancestrais, candomblé de egungum; o candomblé jeje ou jeje-mahi e os candomblés bantos: angola, congo e cabinda.

Já em outros Estados, como no Maranhão, o tambor denominado mina-jeje de tradições dos jejes daomeanos e da denominação mina-nagô. No Estado de Pernambuco, recriaram a nação egbá, que também é nagô. No Rio Grande do Sul, nações iorubanas oyó e ijexá. Em Alagoas, a expressão religiosa xambá, nagô, hoje praticamente extinta.

A reconstituição da religião africana na Bahia, de acordo com Prandi, foi estruturado como a família iorubá, ou seja, a família-de-santo. O candomblé tem a sua estrutura baseada nesta família ioruba: "O grupo religioso é dirigido por um chefe, masculino ou feminino, com autoridade máxima, e o orixá do fundador do 
grupo é o orixá comum daquela comunidade, para qual é levantado o templo principal" (PRANDI, 2000, p. 61).

O critério de tempo de iniciação é o fundamento para determinar a hierarquia nas casas de candomblé. De acordo com Prandi:

As mulheres mais velhas, isto é, iniciadas há mais tempo (e no Brasil o sétimo ano de iniciação ganhou o estatuto de ano que marca a senioridade) chamam-se de egbômi que em iorubá significa "minha irmão mais velha" e que nada mais é que o tratamento que as esposas mais antigas, e por conseguinte mais importantes, do chefe usam entre si (PRANDI, 2000, p. 61).

De acordo com Prandi (2000), as esposas mais velhas chamam as recéminiciadas de iaô, ou jovem esposa. O uso dessas designações reservadas às mulheres, com o passar do tempo, passaram a ser usados com os iniciados masculinos.

Do governo das cidades, segundo Prandi (2000), o candomblé copiou os postos de mando na religião, que ficou organizado da seguinte forma

O conselho do rei de Oyó, cidade de Xangô, inspirou a criação do conselho
de obás ou mogbás em terreiros deste orixá. O general balogun
transformou-se em cargo de alta hierarquia no culto a Ogum. As mulheres
encarregadas de administrar o provimento material da corte do rei
inspiraram as ialodês dos candomblés. A mulher encarregada de zelar pelo
culto a Xangôn no palácio do rei de Oyó, e por isso mesmo chamada Ekeji
Orixá, que significa a segunda pessoa do orixá, foi certamente o modelo do
cargo das equédis, que são as mulheres que não entram em transe e que
vestem e dançam com os orixás incorporados em suas sacerdotisas e
sacerdotes (PRANDI, 2000, p. 62)

A religião africana não sofre separação da sociedade, daí, de acordo com Prandi (2000), muitos aspectos das sociedades africanas foram reconstituídos e reelaborados, dado o contexto da influência da organização dos padrões íberobrasileiros, que prejudicou a formação da família africana aqui no Brasil.

A desestruturação da família africana, prejudicou a formação da identidade sagrada através de uma linhagem biológica. Daí ela ser substituída por uma 
concepção mítica de linhagens, ou seja, para Prandi, "cada indivíduo descende de um orixá, que é considerado seu pai e a quem deve culto" (PRANDI, 2000, p. 62). Independente da família biológica, o orixá de cada um só pode ser revelado pela consulta de um oráculo, ou seja, em terras brasileiras, os pais e mães-de-santo, têm a prerrogativa do poder adivinhatório, o que proporcionou uma depreciação do babalaô. No entanto, o conceito de um segundo orixá que conduz o indivíduo, "o adjunto ou junto, que na África era o da mãe biológica e aqui é identificado através do oráculo (PRANDI, 2000, p. 62).

Foi formada uma África simbólica, que, segundo Prandi (2000), era um local onde o negro poderia proteger das agruras da sociedade branca. Contudo, após a abolição e o processo de integração do negro na sociedade em formação, a adesão ao candomblé tornou-se escolha pessoal.

Já após a primeira metade do século $X X$, o candomblé deixa de ser, de acordo com Prandi, prerrogativa do negro, abrindo-se para todos aqueles que procuravam, independente das origens étnicas e raciais. Ainda segundo Prandi (2000), uma versão branqueada do candomblé foi criada no início do século, a umbanda.

Um movimento de recuperação das raízes culturais que questionava as verdades da civilização ocidental, ou seja, uma volta para as culturas tradicionais. De acordo com Prandi (2000), esse retorno possibilitou uma valorização da Bahia e, sobretudo, da cultura dos candomblés. No entanto, a Bahia não foi suficiente nessa busca pelas raízes

Numa segunda etapa, os brasileiros, agora de todas as origens, voltaram-se em direção à África contemporânea em busca de fontes supostamente mais originais que aquelas preservadas no Brasil pelos descendentes dos escravos, originando-se um movimento que chamei de africanização do candomblé, que nada mais expressa que a valorização das fontes africanas 
exatamente no momento em que ao candomblé adere uma camada de brancos escolarizados (Prandi, 1991; 1996), isto é, quando se faz universal, constituindo-se numa cultura para todos (PRANDI, 2000, p. 63).

A valorização da cultura negra no Brasil, de acordo com Prandi (2000), ocorreu juntamente com os movimentos de minorias, principalmente o movimento negro, avivando-se nos afrodescendentes a questão da origem e da identidade. Os questionamentos sobre a condição africana e afrodescendente, depois de séculos integração forçada, mestiçagem e branqueamento, tem sido objeto de reflexões por populações negras e mulatas.

A superioridade dos nagôs é enfatizada por Prandi: "Como se tudo que é negro remetesse aos povos nagôs, como se todos os deuses fossem orixás" (PRANDI, 2000, p. 64).

Prandi (2000) cita o ensaísta e poeta norte-americano Steven White, que ao analisar poetas brasileiros negros, mostra

(...) como a procura de uma identidade negra, africana, de origem, acaba remetendo à necessidade de se reinventar um passado através da própria religião, que é fonte brasileira por excelência da memória das origens africanas (White, 1999) (PRANDI, 2000, p. 64).

Prandi (2000) conclui que a construção da identidade ocorre não de uma instância originária étnica e racial africana, e sim a partir da cultura brasileira, pois o passado recuperável é o que foi incorporado em nosso processo de construção civilizatório, num passado que passa pela condição de reinvenção. A rotina de suplícios e de humilhações não impediram a reconstrução de suas tradições religiosas e a necessidade de suportarem as agruras do cotidiano fortalecendo a construção de sua religiosidade.

De acordo com Morais (2012), as religiões afro-brasileiras contribuíram para a formação da identidade nacional, como também de base para a constituição de uma identidade negra. No entanto, o estigma da feitiçaria permaneceu como um rótulo 
para religiões que guardam a marca do mistério e do ocultismo, que para a maioria da população e lembrado como algo perigoso e temeroso. Daí a repressão em períodos que culminam até o fim da década de 1970, pelos agentes do Estado. Hoje ocorre uma postura diferenciada do Estado em relação a essas religiões. Conforme Morais (2011), citando Giumbelli (2008), o reconhecimento da religiosidade afrobrasileira ocorreu através de viés culturalista, que permitiu o status no tratamento de patrimônio cultural. O tombamento de terreiros é uma forma de proteção do Estado para as religiões de matriz africana.

Arrancados do continente africano e enviados forçadamente para o Novo Mundo, os africanos que passaram a compor a mão de obra que atuaria na construção do Brasil, via trabalho escravo, não trouxeram apenas a sua força de trabalho para atuarem nestas terras, uma vez aqui, separados de suas famílias e trocados os seus nomes para servirem aos senhores donos de suas vidas, tinham a missão de reerguer-se da situação traumática e reconstruírem as suas vidas, agora no Brasil Colônia.

A história de lutas do povo de santo contra a intolerância religiosa demonstra a capacidade de resistência do negro no Brasil, desde a montagem dos quilombos, e, na atualidade, a manutenção e preservação de seus locais religiosos, como se fossem modernos quilombos em meio a uma sociedade embranquecida e estigmatizadora das africanidades e da religiosidade de matriz africana.

No entanto, ao mesmo tempo que nega a ancestralidade africana e a mistura racial, a sociedade embranquecida não vive sem o trabalho do negro e muito menos renúncia aos conhecimentos ancestrais e da cultura afro-brasileira, demonstrando a vantagem das religiosidades afro-brasileiras e da presença do negro na formação do nosso país. 
O desconhecimento sobre o universo das religiões afro-brasileiras e todas as suas contribuições para a nossa formação cultural é uma barreira para a nossa democracia laica e com respeito à diversidade religiosa. O nosso campo religioso brasileiro está impregnado de contribuições afro-brasileiras e de uma força da tradição africana que ajudou na formação das identidades afro-brasileiras. Essa tradição, conforme Gonçalves e Oliveira (2011), é uma fonte de legitimação das religiões de matriz africana, tanto que esse termo matriz, lembra o autor é para confirmar a origem da tradição africana presente nas religiosidades que buscam a reafirmação de suas tradições africanas positivas, dada a especificidade da sua cosmovisão e de elementos que ajudariam na formação de uma sociedade mais democrática e igualitária, a saber: valorização da coletividade, respeito à diversidade de gêneros, cuidados e respeito aos mais velhos e a sua sabedoria e, por fim, relações mais equilibradas e de respeito ecológico.

As religiões de origem africana no Brasil, até o século XVIII, parecem ter sido calundu, termo de origem banto, que ao lado de batuque ou batucajé designava dança coletiva, cantos e músicas com instrumentos de percussão, invocação de espíritos, possessão, adivinhação e cura mágica. Os calundus, também, antecederam às casas de candomblé do século XIX e aos atuais terreiros de candomblé (SILVA, 2005, p. 43).

Devemos considerar as religiões afro-brasileiras, estruturadas a partir do século XIX e formadas a partir do repertório étnico dos escravos africanos e seus descendentes, com o tempo essas religiões passaram a aceitar outras etnias como membros e buscam na atualidade uma universalização. Essas religiões recebem diferentes nomes regionais, como: Candomblé na Bahia; Batuque, no Rio Grande do 
Sul; Xangô, em Pernambuco; Tambor-de-Mina, Maranhão e Pará; cabula, região do

Espírito Santo; Macumba, do Rio de Janeiro; a Umbanda e a Quimbanda;

A história do desenvolvimento dessas religiões é por dissidências e não por união, dada as especificidades dessas religiões, não há uma liderança unificada que responda por todos os terreiros, pois cada pai de santo (babalorixá) ou mãe de santo (lalorixá) exerce a liderança religiosa para o respectivo grupo sob seu controle, e, em muitos casos, são concorrentes no mercado religioso-mágico da fé nas entidades africanas e afro-brasileiras. Não há um livro ou escritura sagrada única para validar a fé no panteão afro-brasileiro, mas a questão da oralidade, da ancestralidade e do poder dos babalorixás e das ialorixás dão autoridade aos que lideram os terreiros e carregam os "segredos guardados" nos dizeres de Prandi, (2005):

O candomblé é religião minoritária, de poucos fiéis e muitos clientes. Ouvese com frequência que é religião muito trabalhosa, mas boa para comer e dançar. De fato, comida e dança, são elementos vitais dos ritos, e trabalho é o que não falta. Entrar para o candomblé impõem a necessidade de aprender grande quantidade de cânticos e danças, palavras e expressões, modos de se comportar e de se relacionar com os deuses, com os humanos e com os objetos sagrados, além de receitas culinárias, fórmulas mágicas e listas intermináveis de tabus - tanta coisa, que parece não ter fim. $E$ não tem mesmo. Tudo vai sendo aprendido aos poucos, tudo cercado de uma aura de mistério, cada coisa como um segredo novo. E sempre há mais para entender e memorizar a cada etapa da iniciação que nunca termina. Os mais jovens devem aprender ouvindo, observando e imitando os mais velhos, numa rigorosa disciplina baseada na hierarquia iniciática. Descobrem depois que, em algum lugar, pode existir uma cantiga que se perdeu, uma invocação que foi esquecida, uma fórmula ritual que foi corrompida pelo tempo. E não são poucos os que se convencem de que tudo precisa de ser pacientemente recuperado para que se restitua ao axé, a força sagrada dos orixás, seu antigo poder, sua extrema capacidade de mover e mudar o mundo. Para quem inicia a travessia, tudo é novo e misterioso, a começar pela língua ritual de origem africana, que se decora, mas pouco se traduz. São um sem-fim os mistérios a decifrar, outros tantos a recuperar. O devoto do candomblé aprende, desde cedo, que são muitos os segredos guardados (PRANDI, 2005, p. 10/11).

De acordo com Moura (2000), em sua obra, Candomblé - religião de corpo e alma, temos: 
Os seguidores das religiões que nos legaram algumas populações negroafricanas, sequestradas para as Américas pelas brutalidades do escravagismo, vivenciam, inspirados por suas divindades - orixás, voduns, inquices - a crença de que a vida é o bem supremo. (...) A recompensa por uma existência vivida em plenitude não se situa numa eterna bemaventurança, na contemplação infinda do Divino, após a morte. Na concepção dos nagôs, o Ayê, o mundo em que estamos, não é o vale das lágrimas, mas das venturas (...) Passar do plano supraterrestre do Órun para a realidade material do Ayê não é uma imposição cármica, uma expiação de faltas passadas, mas uma escolha, ditada pelo Ori de cada um, isto é, a cabeça, sede de todo conhecimento, de todo arbítrio e que, por isto mesmo, tem de ser constantemente louvada, zelada, cultuada (MOURA, 2000 , p. 8).

As comunidades tradicionais de terreiro apresentam diferenças quanto ao modo de organização de suas manifestações religiosas. Isso acaba resultando em uma situação de disputa interna sobre a questão do que é ou não autêntico, africano ou distanciando-se do africano, ou ainda, do que é puro ou impuro.

Nos estudos sobre a Umbanda paulista (NEGRÃO, 1996, p. 27/28), na sua obra Entre a Cruz e a Encruzilhada, critica a forma paradigmática do Candomblé e de autenticidade evidenciadas nos trabalhos de Roger Bastide. Já para a Umbanda e a Macumba, Bastide, apresenta-as como formas degradadas das religiões afrobrasileiras. Negrão demonstrou a existência de terreiros de Umbanda organizados desde a década de 20 do século passado e de uma forte repressão policial sobre esses terreiros que os levavam a se registrarem como centros espíritas kardecistas para fugirem da criminalização aos quais eram vítimas.

Citando Renato Ortiz, que entende a Umbanda como resultado de influências culturais católicas, afro-brasileiras e kardecistas, fundindo-se em algo novo e sem o predomínio de nenhum dos seus elementos constitutivos, um sobre o outro. No entanto, como o próprio título de sua obra indica "A Morte Branca do Feiticeiro Negro" foi consolidado um apreço aos elementos constitutivos brancos e ocidentais sobre o negro e mágico (NEGRÃO, 1996, p. 30). 
De acordo com Prandi (1998), a história das religiões afro-brasileiras pode ser dividida em 3 situações:

(...) primeiro, o da sincretização com o catolicismo, formando as modalidades tradicionais como o candomblé, xangô, tambor de mina e batuque; segundo, o do branqueamento na formação da umbanda nos anos 20 e 30; terceiro, da africanização, na transformação do candomblé em religião universal, isto é, aberta a todos, sem barreiras de cor ou origem racial, africanização que implica negação do sincretismo, a partir dos anos 60 (PRANDI, 1998, p. 151/152).

O problema da questão da preservação e da busca de uma religião originária e pura levam-nos a questões de aceitação e perda de uma identidade e uma identificação com costumes ou práticas obtusas e inconclusas, proporcionando conflitos e dissidências dentro do campo afro-brasileiro.

Ainda, de acordo com Prandi:

Até os anos 1930, as religiões negras poderiam ser incluídas na categoria das religiões étnicas ou de preservação de patrimônios culturais dos antigos escravos e seus descendentes, enfim, religiões que mantinham vivas tradições de origem africana (PRANDI, 1998, p. 152).

Para Prandi (1998, p. 153), as religiões afro-brasileiras foram moldadas pelas condições sociais diversificada e apresenta facetas de valorização de elementos constitutivos ou a negação deles, abraçando o catolicismo, às vezes, ou rejeitando-o.

Sobre o sincretismo, as religiões afro-brasileiras formaram-no com o catolicismo e, ainda, de acordo com Prandi ocorreu, de forma menos acentuada, também com as religiões indígenas. A prática dos santos foi ajustada aos panteões africanos. Por certo, ao admitir a possibilidade sincrética, não devemos deixar de lado, a constatação da premissa, na qual a origem das religiões de bantos, iorubás e fons, são de cultuar ancestrais, originados das famílias e suas linhagens. Porém, ao se depararem com a violência do sistema de escravização formado nas Américas, o 
culto ancestral foi dissolvido e passou por reelaborações, dado ao novo contexto de imposição e massacre de suas origens e, principalmente, de sua fé nos ancestrais.

No novo contexto, ao negro que sofreu a violência da diáspora, restava lutar pela sobrevivência, em uma sociedade imposta pelo branco que infligia formas de submissão aos quais passava pela destruição da identidade africana e da imposição de uma realidade na qual consistia na catolicização, desde sua retirada do continente africano até o momento de sua morte. Na rotina da sociedade branca dominadora restava para o negro ser brasileiro. Mas ser brasileiro obrigatoriamente levava a submissão de seu crer ao mundo católico predominante no Brasil Colônia (PRANDI, 2000, p. 1545).

O movimento de reafricanização é inicial e recente, de acordo com Prandi (2000). A elucidação desse processo é esclarecida pelo autor em uma nota, na qual consta

\footnotetext{
Trata-se do movimento de africanização do candomblé, que procura desfazer o sincretismo com o catolicismo e recuperar elementos rituais perdidos na diáspora negro-africana, além de reaprender a língua iorubá. Entre suas importantes lideranças destacam-se Mãe Stella Azevedo do Axê Opô Afonjá da Bahia e Mãe Sandra Medeiros Epega do llê Leuiwyato de São Paulo (PRANDI, 2000, p. 155).
}

Para entender essa reafricanização, Prandi alerta-nos sobre a questão do branqueamento das religiões afro-brasileiras e sua expressão na formação da Umbanda no Brasil. Evocando a penetração dos estudos do kardecismo na sociedade brasileira, já no início do século passado e resultando na formação da religião de Umbanda ou também como espiritismo de umbanda. A formação deste, segundo Prandi (2000, p. 156) ocorreu dado às dissidências do espiritismo kardecista que não aceitava a presença de guias negros e caboclos em suas sessões. 
Nascendo de uma dissidência, porém permeada de uma cultura branca europeizada e fortemente realocadora de manifestações africanas em suas sessões que buscava, de uma maneira ou outra, limpar suas giras de manifestações que remetessem aos usos de tradições e ritos africanos ou que lembrassem estas realidades. Esse processo é denominado "branqueamento", isto é, ao impedir uso de tambores, álcool, fumo, pólvora e entre outros manifestações, tenta-se oferecer ao cidadão mediano e branqueado, uma forma de manifestação aceitável aos padrões europeus e uma ocultação de elementos que, dado ao fato de sofrerem uma forte repressão do governo, principalmente o período da ditadura Vargas (1937-1945).

De acordo com Prandi, estas mudanças ocorreram devido à influência do espiritismo kardecista na montagem da organização e funcionamento do espiritismo de umbanda.

Esse "branqueamento", tal como o "sincretismo" inicial das religiões de comunidades tradicionais de terreiro, perpassam estratégias de defesa dessas manifestações diante de uma sociedade fortemente racista e branqueada como a sociedade brasileira.

Como afirma Munanga (2006, p. 53), “(...) O nó do problema está no racismo que hierarquiza, desumaniza e justifica a discriminação existente." Enfim, o racismo no Brasil para (Munanga) foi criado "com base na negação dele".

A religião espiritismo de umbanda foi criada de acordo com os moldes sociais em que "todos os brancos e negros no Brasil acreditam na 'mistura racial' como fundante da sociedade brasileira" (MUNANGA, 2006, p. 52).

Ao abordar a umbanda como uma religião branqueada e modificada ao sabor do status quo dos dominadores culturais, Prandi conclui que 
Assim, até o final dos anos 50, a história das religiões afro-brasileiras é uma história de apagamento de características de origem africana e sistemático ajustamento à cultura nacional de preponderância europeia, que é branca. Mas, no processo de branqueamento, muitas práticas rituais e concepções religiosas negras impuseram-se na sociedade branca (PRANDI, 2000).

O ajustamento e a moldagem aos padrões dominantes, nem sempre significam o apagamento e destruição de uma cultura rotulada como inferior ou demonizada como a cultura africana. A sociedade é branqueada, mas isso não significa a superação e a destruição da cultura e influência da cultura negra na cultura brasileira. Ao analisarmos a superação das comunidades tradicionais de terreiro afro-brasileiras diante dos ataques intolerantes e de sua desproporcional magnitude na atualidade, tendo em vista, o uso e abuso de poderes políticos e jurídicos para impedir as religiões de realizarem suas giras e tocarem seus tambores, ou entrando no mérito do sacrifício ou não de animais, na diversidade de religiões afro-brasileiras, percebemos que, por mais que tentem apagar, menosprezar, diluir ou minimizar a influência religiosa afro-brasileira, deparamos com uma resistência significativa e louvável que não provém de setores dominantes, mas de uma superação ao establishment branco, com ações dos próprios afroreligiosos e da contribuição do Movimento Negro atual.

Devemos considerar os conceitos de Birman, que evocam a questão dos ritos de possessão e dois grandes marcos: "os terreiros de "umbanda" que "trabalham" fundamentalmente com "espíritos" versus aqueles de "candomblé" que "trabalham com "orixás"." Continuando sobre as constatações da autora acima ela demonstra um contraste através de duas analogias

(...) o candomblé é ritualmente estruturado, a umbanda é ritualmente mais flexível; o primeiro é um culto "mais africano", o segundo é "mais brasileiro"; o primeiro guardaria valores comunitários da sociedade africana de origem, o segundo apresentaria comportamentos associados a valores provenientes da sociedade inclusiva. 
Esses contrastes, desenvolvidos na obra de Bastide, são apontados pelos mais diversos autores que, de forma geral, além de reconhecê-los, estabelecem um valor hierárquico entre estes. O culto mais flexível, (de certo modo visto como de menor valor) que parece manter uma relação de continuidade com a vida social de seus integrantes, é invariavelmente apresentado como pertencente à umbanda, enquanto o culto que segue um modelo menos flexível, mais estruturado e com uma certa distância em relação à sociedade - mais africano - (e de maior valor) é identificado como candomblé (BIRMAN, 1995, p. 25/26).

O trabalho de Birman (1995, p. 26) deixa claro que há diferenças entre o candomblé e a umbanda e que elas são ressaltadas pelos diversos autores da literatura existente. No entanto, para ela o que não fica claro é: "o sentido que estas possuem para aqueles que vivem a experiência religiosa do seu interior.”

Ao constatar que os afro-religiosos não se apegam as questões da multiplicidade do campo da possessão e devem compromissos com os seres de outra esfera para melhor enfrentar os desafios diários. E, ainda, ao mudar de uma casa religiosa para outra, busca-se realizações pessoais e não artifícios teóricos que só dizem respeito aos acadêmicos e suas teorias. Na prática, os afro-religiosos querem transformações que incidem sobre eles próprios (BIRMAN, 1995, p. 27/28).

Ocupar-se com as suas obrigações com os espíritos ou com os orixás demonstra, de certa forma, uma busca por vínculos superiores e não a mera realização de pulsões instintivos e necessidades materiais imediatas. Essa ligação uma vez efetivada dificilmente é rompida com a pecha de "demonização" ou até mesmo com os ataques intolerantes direcionados aos símbolos, casas religiosas ou aos próprios frequentadores. A fé dos afro-religiosos, mesmo com todos os ataques, funciona como a principal forma de reação aos ataques intolerantes ao seu modo de crer e viver. O axé transforma a vida do indivíduo e dá forças para resistir aos piores cenários possíveis de imaginar ou viver, dado o histórico de violência direcionada aos praticantes das religiões de comunidades tradicionais de terreiro. Não há temor pela vida ou mesmo pela destruição da religião, ao longo de toda sua história, desde 
o surgimento até os dias atuais os ataques foram diversos e a fé nos orixás e nos espíritos só fortalecem os adeptos de religiões afro-brasileiras.

De fato, constatamos que a umbanda tem sofrido um decréscimo nos seus praticantes de acordo com os números do censo de 2010: "Segundo dados do Censo de 2010, o número de umbandistas hoje no Brasil, 110 anos depois de sua fundação, chega a 432 mil. Uma queda de $20 \%$ em relação ao Censo de 19912".

A mudança interna dos afro-religiosos deve ser considerada na atualidade, conforme Birman:

A distinção que se mostra mais importante entre os cultos, do ponto de vista
destas pessoas que passaram para o candomblé, é aquela referida como
"feitura", "raspagem". "A umbanda não raspa" significa algo mais que uma
especificidade de culto - para essas pessoas é uma qualidade diferencial
que diz respeito à esfera de poderes sobrenaturais junto à qual a umbanda
não detém competência. Aqueles capazes de manipulá-la são igualmente
capazes de alterar os componentes que integram a pessoa, dar-lhes a
outros entes, modificar a relação que entretêm com os antigos (BIRMAN,
1995, p. 31)

Quais as ações de resistência verificadas na atualidade? Como os afroreligiosos se organizam? Como o Movimento Negro tem contribuído para a preservação das manifestações afro-religiosas?

Ao nos depararmos com estas questões, devemos levar em conta não o histórico de intolerância, mas a reação ao histórico dos afro-religiosos e de suas formas de organização contra uma avalanche de críticas, preconceitos e ataques, desferidos, constantemente, contra a fé dos praticantes das religiões de comunidades tradicionais de terreiro.

As notícias sobre atos intolerantes geralmente têm mais relevância do que os momentos de valorização e preservação da fé nas religiões de matriz africana. A humildade, a sinceridade, o mundo tal como é abordado pelos afro-religiosos não

\footnotetext{
${ }^{2}$ Disponível em: <https://www.bbc.com/portuguese/brasil-44297088> Acesso em 13 jun. 2019.
} 
são colocados em horário nobre nas redes de televisão brasileiras. Dificilmente temos atos e manifestações de apoio às religiões afro-brasileiras, são raros os momentos que os praticantes das religiões de comunidades tradicionais de terreiro têm direitos de respostas, aos ataques desferidos as suas formas de cultuar os orixás e entidades louvadas tem demonstrado uma faceta do perverso "racismo à brasileira", como nos lembra Hédio Silva Junior, em seu precioso artigo (SILVA, 2007, p. 303).

A organização do povo de santo remonta à sua formação enquanto religiões estruturadas, ou seja, anteriores às atuais formas de perseguição aos afroreligiosos. No entanto, o africano arrancado e jogado no solo brasileiro utilizado na base de sustentação do sistema escravista colonial, já enfrentava o problema do não reconhecimento de sua identidade, em sociedades ibéricas que definiam como demonstra Munanga:

A lei de pureza de sangue vigente em Portugal e Espanha dos séculos XIV$\mathrm{XV}$, que deu origem ao antissemitismo, que é uma subvariante do racismo, não precisou da raça no sentido moderno da palavra. No entanto, a lei da pureza de sangue na Península Ibérica não era tão diferente das leis de Nuremberg durante o regime nazista (MUNANGA, 2006, p. 54).

O africano estigmatizado, forçado a sustentar um sistema idílico da superioridade dos europeus sobre os demais povos da terra e, obviamente, da religião "verdadeira" sobre as manifestações inferiores e que remetiam ao não reconhecimento e perseguições da religiosidade dos arrancados do seu solo e de sua ancestralidade sagradas na África.

$\mathrm{Na}$ construção de uma religiosidade em outro solo que não o seu, não podemos adotar critérios de pureza religiosa. As condições nas quais remontam as manifestações aos ancestrais e nos orixás promove mudanças e adaptações necessárias ao novo contexto em questão. Um lugar onde não era tratado como ser 
humano dotado de liberdade e muito menos de sabedoria para cultuar, o ambiente sincrético proporciona adaptações que depende da região e do grupo, grosso modo, linguístico formador da religião em questão. Os grupos linguísticos africanos no caso são os bantos e sudaneses. Utilizo dos estudos de Hall (Hall, 2003, p. 26), na qual cita Benedict Anderson, que diz que as nações são "comunidades imaginadas", um "sujeito imaginado" é citado, neste caso, para lembrarmos dos rótulos aplicados ao africano que chega ao Brasil e é rotulado de origem banto ou sudanesa. Mas, na verdade, a origem dos africanos que foram arrancados de suas diversas regiões é simplesmente com rótulo da África como declara Hall

Sabemos que o termo "África" é, em todo caso, uma construção moderna, que se refere a uma variedade de povos, tribos, culturas e línguas cujo principal ponto de origem comum situava-se no tráfico de escravos (HALL, 2003, p. 31).

Enfim, os critérios de pureza são pulverizados no Novo Mundo devido aos diversos contatos de povos aqui em novas condições.

As novas possibilidades do Novo Mundo levam ao que Hall denomina de "crioulização", isto é:

(...), mas a lógica colonial em funcionamento aqui é evidentemente uma "crioulização" ou do tipo de "transcultural", no sentido que Mary Louise Pratt dá ao termo, seguindo a tradição de alguns dos melhores textos teóricos culturais da região. Através da transculturação "grupos subordinados ou marginais selecionam ou inventam a partir dos materiais a eles transmitidos pela cultura metropolitana dominante". É um processo de "zona de contato", um termo que invoca "a co-presença espacial e temporal dos sujeitos anteriormente isolados por disjunturas geográficas e históricas (...) cujas trajetórias agora se cruzam (HALL, 2003, p. 31).

Hall, também, chama à atenção aos conceitos de diáspora e da noção derridiana de differance

O conceito fechado de diáspora se apoia sobre uma concepção binária de diferença. Está fundado sobre a construção de uma fronteira de exclusão e depende da construção de um "Outro" e de uma oposição rígida entre o dentro e o fora. Porém, as configurações sincretizadas da identidade cultural caribenha requerem a noção derridiana de differance - uma 
diferença que não funciona através de binarismos, fronteiras veladas que não separam finalmente, mas são também places de passage, e significados que são posicionais e relacionais, sempre em deslize ao longo de um espectro sem começo nem fim. A diferença, sabemos, é essencial ao significado, e o significado é crucial à cultura (HALL, 2003, p. 33).

O que move Hall ao estudar a questão da cultura negra não é aceitação simplista do negro na sociedade inglesa e sim a dificuldade de aceitação do negro da diáspora em uma sociedade marcadamente machista, racista e impositiva de uma suposta superioridade branca ao aceitar os cidadãos do extinto Império Colonial Inglês (HALL, 2003, p. 12). O ambiente não é agradável e muito menos passível de uma compreensão do outro, em uma Inglaterra do pós lutas de independência dos povos submetidos ao domínio colonial inglês. De acordo com Hall, o essencialismo não confere uma automática libertação da subjugação dos detentores do poder (HALL, 2003, p. 12/13). No afã de libertar-se das amarras do sistema de dominação e de das discussões simplistas sobre as estruturas econômico-sociais, ele confere aos Estudos Culturais uma importância ao proporcionar a formação de um intelectual orgânico, ou seja, pessoas comprometidas com uma formação intelectual que proporcionaria mudanças sociais e econômicas (HALL, 2003, p. 14). A identidade negra tem valor estratégico na luta contra o racismo.

Temos com Hall uma luta contra o economicismo do marxismo clássico, devido à sua perspicaz observação de uma dedicação pequena por parte do marxismo ao cultural, ao simbólico e à ideologia, bem como de um certo eurocentrismo implícito no modelo de transformação capitalista de Marx (HALL, 2003, p. 16).

As religiões de comunidades tradicionais de terreiro não apresentam as normas e a rigidez de um ritual cristão, ou seja, para Birman “o sagrado 'incorporado' 
entre os homens, ali, falando, comendo, bebendo, aconselhando, dançando." Temos "uma cena de possessão". O contato "direto", como ela afirma com o sagrado (BIRMAN, 1995, p. 4).

Para reforçar essa diferença de vivência com o sagrado enfatizamos

Já chamei atenção para a diferença que as religiões possessão instauram na sua relação com a esfera sobrenatural. A presença desta na Terra parece abrir espaço nos cultos que exploram - através das relações com o corpo, com a comensalidade, com a festa - dimensões dionisíacas bem distantes das religiões do Verbo - onde prevalecem a interioridade, a ausência de ritos e pouco encantamento (BIRMAN, 1995, p. 6).

Estas demonstrações de um sagrado festivo e encantado não são evidenciadas como religião certa ou mesmo como um sagrado autêntico. As acusações de ilegitimidade destas manifestações levam aos casos de intolerância religiosa com acusações de bruxaria, magia negra ou manifestações do demônio. Atritos e lutas têm levado alguns desses casos para a divulgação na imprensa e bem como em tentativas de resolução em órgãos da Justiça brasileira. Mas os casos de violência contra os praticantes das religiões de comunidades tradicionais de terreiro têm sofrido um acréscimo significativo nos últimos anos ${ }^{3}$.

A questão da violência contra os afro-religiosos é escancarada e a resposta do Estado para assegurar o direito à liberdade religiosa tem sido desanimadora e, muitas vezes, deixa transparecer que os praticantes das religiões de comunidades tradicionais de terreiro estão abandonados e desamparados, mas não por falta de reação diante dos ataques contra as suas formas de crer e viver na sua fé ${ }^{4}$.

Dentro do próprio campo das religiões de possessão, segundo Birman, há diferenças e elas podem opor manifestações de umbanda e de candomblé pais-23400711

3 https:/oglobo.globo.com/sociedade/denuncias-de-ataques-religioes-de-matriz-africana-sobem-47-no-

4 https://g1.globo.com/rj/rio-de-janeiro/noticia/2019/07/17/brasileiro-recebe-premio-do-governo-dosestados-unidos-pela-luta-contra-a-intolerancia-religiosa.ghtml 
Contudo, no âmbito mesmo das religiões de possessão, encontramos diferenças significativas entre suas práticas e entre os ethos que veiculam. Não é em todos os cultos de possessão que a presença do sobrenatural se faz desse modo. Dentro de certos limites, é possível opor alguns "dionisíacos" a outros, digamos, "quase-ascéticos". Grosso modo, essa oposição corresponde, num plano, à diferença entre cultos de umbanda e cultos de candomblé; e noutro plano, entre cultos de possessão praticados por mulheres e cultos praticados por homens (BIRMAN, 1995, p. 6).

A formação da identidade e o reconhecimento de práticas e ritos oficiados por gêneros diferentes é o objetivo de Birman em sua obra. No entanto, o que pretendemos é evidenciar as circunstâncias que levam a demonização e mesmo os constantes ataques aos religiosos de comunidades tradicionais de terreiro.

Uma forma de demonstrar essa falta de legitimidade e, ao mesmo tempo, a desconsideração de um determinado terreiro - ou até mesmo deslegitimá-lo diante dos demais de maneira pejorativa - é a utilização do termo Macumba, como notamos na nota utilizada por Birman (1995) para explicá-la

\begin{abstract}
Macumba, por sua vez, é termo de uso genérico em referência a todas as formas de culto "afro". É geralmente empregado pelos religiosos de maneira irônica e jocosa, como forma de indicar o reconhecimento que se possui a respeito do estigma que recai sobre essas atividades religiosas. Há sempre no uso do termo macumba o reconhecimento de que este representa o polo da religião visto como "impuro" e sujeito a estigma, em oposição a outras práticas religiosas situadas no polo legítimo e vistas como "puras" e "genuínas". Estou usando o termo macumba tendo presente que, em sentido restrito, é o que na literatura se opõe a candomblé ortodoxo; e, em termos amplos, procurando enfatizar o reconhecimento dessa polaridade e principalmente do estigma que recai sobre a totalidade do povo-de-santo. Percebe-se entre os religiosos que quando querem fazer uma referência não mais jocosa, mas que sublinhe um uso educado da língua e, por meio desta, o reconhecimento do valor desses cultos, referem-se a eles como "espíritas", e assim dizem: "o espiritismo é uma religião muito bonita", incluindo-se nessa denominação de "espírita" as macumbas de todos os matizes (BIRMAN, 1995, p. 7).
\end{abstract}

O uso jocoso e até popular do termo macumba leva a uma depreciação da religião tanto interna, quanto externamente. No meio externo, a desqualificação dos rituais afro-brasileiros resulta nos atos de intolerância perpetrados por fanáticos religiosos estimulados por discursos beligerantes da teologia da "Batalha Espiritual" 
contra o diabo e seus seguidores, identificados, neste caso, com os afro-religiosos e suas formas de cultuar o sagrado.

A fé nas religiões de comunidades tradicionais de terreiro, especificamente, o lado impuro é identificado com o mal, exus e pombagiras, personificam o lado negativo da religiosidade afro-brasileira? A divisão entre o que é puro, mais africano, e lado impuro, o lado afastado das comunidades tradicionais de terreiro que sofrem influências diversas, resultando em uma impureza na forma de cultuar.

Não devemos considerar as comunidades tradicionais de terreiro como religiões tradicionais, que expressam determinados formas de manifestações padronizadas e coordenadas por uma hierarquia maior e fora de suas respectivas casas religiosas. Apesar das tentativas de centralização e de uma determinada padronização das religiões afro-brasileiras, devemos identificar tais formas religiosas como autônomas e independentes entre si, com atesta Birman (1995, p. 14)

Dissemos que esses cultos de possessão, com frequência pensados como religiões autônomas e independentes entre si, possuem, no entanto, vinculações que deixam entrever um princípio na base da sua estruturação que impõe uma relação de interdependência uns dos outros e uma certa coerência ao conjunto.

Os estudos sobre as religiões africanas no Brasil têm focado na busca de critérios e da separação de religiosidades que pareciam uns com os outros. Portanto, foram verificadas, como atestou Birman (1995, p. 14), diversas heranças culturais, cada qual com a sua especificidade. Mas, a certeza de "uma impossibilidade de encontrá-las tal como deveriam ter sido antes de se transformarem em pequenos indícios de culturas que se perderam”.

A base religiosa ou melhor um padrão tentado pelos primeiros pesquisadores e muitas vezes defendido como uma regra a seguir é a experiência religiosa dos negros iorubás. 
O que devemos deixar claro é que não queremos desqualificar a importância e a organização dos diversos candomblés e muito menos colocá-los em patamares inatingíveis de pureza e autenticidade sobre a sua formação, que de certa forma, sofreu influências dos povos aos quais relacionavam e montaram uma estrutura religiosa que tenta chegar ao patamar de pureza africana, mas já não é tal como foi encontrado ou oriundo do continente africano. A africanização, neste caso, seria um desejo de perfeição ritual. No capítulo pensando a diáspora: reflexões a terra no exterior sugere que

\footnotetext{
A alternativa não é apegar-se a modelos fechados, unitários e homogêneos de "pertencimento cultural", mas abarcar os processos mais amplos - o jogo da semelhança e da diferença - que estão transformando a cultura no mundo inteiro. Esse é o caminho da diáspora, que é a trajetória de um povo moderno e de uma cultura moderna. Isso pode parecer a princípio igual mas, na verdade é muito diferente - do velho "internacionalismo" do modernismo europeu (HALL, 2003, p. 47)
}

No caso de escolhas entre as diversas religiões de possessão, Birman (1995, p. 17) esclarece que ocorre uma permeabilidade na qual o indivíduo escolhe a casa religiosa, mas a recíproca de ser escolhido pela casa pode acontecer. São manifestações religiosas que pertencem a um plano real, mas na mesma casa temos dimensões: uma natural e a outra sobrenatural. A violência contra os afroreligiosos decorre de uma visão estigmatizada do praticante no plano real e de seus desdobramentos no sobrenatural. Os símbolos, as casas com seus assentamentos, os tambores e as suas respectivas músicas rituais provocariam um furor aos elementos que visualizam tais atitudes como demoníacas. O caso da possessão provoca a total ojeriza, deboche e irritações daqueles que detestam a religiões afrobrasileiras e passam das ofensas para a agressão e a respectiva acusação de demonização por parte dos intolerantes que os desferem seus ataques. 
Essa relação dos afro-religiosos com o mundo sobrenatural, de acordo com Birman (1995, p. 18), depende do que é ofertado ao indivíduo: a crença desse "outro mundo" na sua realidade, as regras impostas ao praticante, coloca limites gera benefícios aos fiéis das religiões afro-brasileiros. Já o outro lado, os intolerantes, estigmatizam os caminhos traçados pelos praticantes das religiões de comunidades tradicionais de terreiro como caminhos que conduzem à perdição, ao inferno e que essas pessoas estariam sendo servidores do mal no plano físico. Já Birman acredita que a multiplicidade de religiosidades significa a presença de uma diversidade de "espécies" sobrenaturais em nosso meio por meio dos "braços" que diferenciam as práticas religiosas e nas diversas formas de manifestação da possessão.

Para delimitar linhas e nações Birman enfatiza que os afro-religiosos lidam com forças de uma sobre natureza requerendo a compreensão de um mundo encantado e diferenciado do mundo cartesiano e materialista dos intolerantes

\begin{abstract}
A multiplicidade no plano da natureza seria, pois, responsável pela multiplicidade de formas de culto. O mundo invisível é variado, divide-se em inúmeras "linhas" e "nações", e essa variedade é a mesma que se apresenta nos terreiros, que se organizam diferencialmente de acordo com suas filiações a tipos e espécies diversos.

No lugar de um mundo humanamente fragmentado vê-se um mundo que inclui uma sobrenatureza como um dos fatores que atuam na criação de suas diferentes espécies. Duplos sobrenaturais e divinos são constantemente mencionados para explicar as características dos seres e o pertencimento destes a certas "linhas" e "nações".
\end{abstract}

Não podemos acusar de crendices sem sentido ou de charlatanices a fé que produz sentido e esperança para aqueles que, muitas vezes, estão jogados à própria sorte, devido ao abandono do Estado nas periferias das cidades brasileiras ou até desacreditados e humilhados por uma sociedade que não aceita sequer a existência do diferente de suas próprias visões e convicções. Nestes momentos de escalada da desumanidade em nossa sociedade, a fé é uma garantia para acalmar e abrandar os conflitos e intolerâncias aos que buscam respostas aos seus 
sofrimentos com os seres de um campo religioso diverso, porém articulado e coerente para aqueles que frequentam.

Muitas vezes, ao serem submetidos a determinadas provações ou situações constrangedoras, como foi citado por Birman, a história de vida de Dona Jandira, que ao não acatar as exigências do seu orixá de cabeça teria graves problemas e até a possibilidade de morte, demonstra a questão do ser escolhido para uma determinada função que é ao santo que corresponde ao "dono de sua cabeça". Não estamos aqui discutindo sobre escolhas religiosas, essa questão de Dona Jandira está além da possibilidade de avaliações, ela remete ao plano sobrenatural para a ação e reflexão dos fiéis. Como confirma Birman, essas instituições religiosas não são somente humanas. "Ou melhor, são também humanas e terrenas" (BIRMAN, 1995, p. 22).

O aspecto da mudança de Dona Jandira está pautado por razões humanas que sofreram fortes influências da esfera sobrenatural a qual ela vincula-se de forma essencial. Neste caso, a mudança ocorreu de uma "linha" para outra. Não foi uma exclusão do passado e sim um reordenamento de sua vida conforme as exigências dos seus orixás. Portanto, de acordo com Birman, "a umbanda se mostrou insuficiente diante da força do orixá do candomblé."

Para entender as nações e linhas devemos analisar diversos estudos sobre essa temática e inicialmente, teremos essa configuração

\footnotetext{
A nação bantu trouxe seus inquices e bacurus; a nação iorubá chegou com seus orixás e a ancestralidade; e a nação fon, seus voduns. Embora estas divindades possam ter algumas semelhanças, existem entre todas elas grandes diferenças de comportamento, de personalidade, de dança, de vestimenta, de alimentação, de comunicação. Enfim, são divindades distintas, de locais distintos, porém com um mesmo ideal: ajudar o ser humano a ser mais feliz! (KILEUY; OXAGUIÃ, 2009, p. 38)
} 
A busca de uma origem e de uma originalidade africana tem sido um fator importante para o estabelecimento do candomblé, principalmente, como religião para todos ou uma religião universal, voltada para um público geral.

A aceitação do candomblé ou das demais formas de religiosidade afrobrasileiras nas demais unidades da federação tem enfrentado dificuldades e ataques sistemáticos nas suas respectivas casas e templos, os tempos de intolerância religiosa sistemática e avassaladora e a repercussão deles nos meios midiáticos leva-nos a perguntar sobre a reação dos afro-religiosos diante desta situação. A reação verificada está na sua peculiaridade de religiosidade não proselitista, participante da cultura e manifestações culturais, e, acima de tudo, a busca de uma universalidade na solução de problemas, mesmo para aqueles que os perseguem e os demonizam. A busca de uma pacificação, um caráter não beligerante, mesmo em meio a uma guerra declarada, onde lideranças de terreiros são expulsas e obrigadas a saírem das respectivas comunidades aos quais pertencem, denota uma reação através da demonstração da superioridade de atitude e não na contraofensiva baseada na reciprocidade de tratamento.

\subsection{A QUESTÃO DA INTOLERÂNCIA RELIGIOSA COMO ATAQUE ÀS IDENTIDADES AFRO-BRASILEIRAS}

A luta por respeito, dignidade e tolerância, agora, passou a ser contestada por setores descomprometidos com a formação de uma sociedade democrática. Pois, de acordo com Bento (2003), o branqueamento, ou seja, a noção de que o negro se sente descontente por ser negro, ou, ainda, de que o branco, ou tudo que é oriundo de seu berço civilizatório, isto é, do continente europeu, é modelo universal para a humanidade. Tudo isso reforça a supremacia econômica, política e social da elite 
branca brasileira, sobre os não-brancos e demonstrações de racismo, como no caso da estigmatização das religiões de comunidades tradicionais de terreiro e de suas práticas religiosas.

Ao buscar uma sociedade mais tolerante ao povo de santo, será necessário enfatizar a retomada da democracia, do diálogo, do respeito e, principalmente, do cumprimento das leis no Brasil. Pois o desrespeito às leis está jogando o país ao obscurantismo das soluções radicais, da intolerância, do racismo e da perpetuação do descaso e da desigualdade às minorias, incluindo, nesta situação, os praticantes das religiões de comunidades tradicionais de terreiro e a sua religiosidade, que precisam de ser conhecidos e reconhecidos por mais e mais cidadãos para que não seja estigmatizada, perseguida e depreciada, como ocorre nesse lamentável cenário religioso e social do Brasil da atualidade.

Os casos de ações intolerantes contra os praticantes das religiões afrobrasileiras levam-nos a refletir sobre esse problema que causa estranheza e dificuldades de lidar com essa questão da busca de um diálogo ou mesmo de uma convivência mais tolerante entre aqueles que atacam, ou seja, que utilizam de ataques contra os fiéis das religiões de comunidades tradicionais de terreiro, como esclarece Silva (2015, p. 9): “O termo ‘ataque' está sendo usado aqui no sentido de investida pública de um grupo religioso contra outro" e aqueles que sofrem os ataques intolerantes e buscam uma reação a estes casos, que de acordo com Silva (SILVA, 2015, p.10) "antes apenas um esboço isolado e tímido de algumas vítimas, agora se faz em termos de processos criminais levados adiante por pessoas físicas ou instituições públicas, como ONGs e até mesmo a Promotoria Pública.”

Esse problema da falta de tolerância, como ressalta Silva (2015, p. 9) "podemos incluir nesse processo também algumas igrejas mais antigas, as quais, 
talvez por influência das mais recentes, estão adotando posições cada vez menos tolerantes em relação às religiões afro-brasileiras", que atinge o outro grupo religioso justificando sua agressão com base nas ações de expulsão e luta contra o mal e o demônio, determina uma situação calamitosa e uma série de impasses.

No período colonial, no Brasil, a intolerância era institucionalizada pela Igreja Católica através do Tribunal do Santo Ofício e suas perseguições e execuções. Após a independência do Brasil, continuavam as relações entre o poder político e a religião católica. Tanto que no Império, através de uma Lei em 1830 havia a punição para: "A celebração, propaganda ou culto de confissão religiosa que não fosse o oficial (art. 276)" (CAMPOS; RUBERT, 2014, p. 296). Essa era a imposição do catolicismo como religião do Estado. No entanto, os negros preservavam suas práticas que foram recriadas no Brasil devido a influência de outros contextos culminando num sincretismo religioso.

A partir de 1889, depois da Proclamação da República, ocorre a separação entre a Igreja Católica e o Estado e a introdução da laicidade, tanto que, na Constituição de 1891, foi abolido o conceito de religião oficial e introduzido a liberdade de qualquer tipo de crença. Mas, as religiões não cristãs, sofreram preconceitos, discriminações e repressões por parte do Estado, pois as religiões mediúnicas ou de possessão, não eram reconhecidas como religião. Esse status inferior não impediu que os praticantes do espiritismo e das religiões afro-brasileiras usassem como forma de se enquadrar na noção de religião o princípio da caridade.

As religiões com práticas mediúnicas enfrentaram dificuldades de manifestações no espaço público devido as atuações intolerantes do Estado, com base em teorias raciológicas, principalmente visando embranquecer a sociedade brasileira, pois no Código Penal de 1890 (vigorou até 1942) havia a previsão de 
punições para: capoeiragem, curandeirismo, vadiagem e espiritismo. As práticas das religiões de comunidades tradicionais de terreiro estavam enquadradas no Código Penal como "Crimes contra a Saúde Pública". Percebemos que o direito configura em uma etapa de controle social sobre as manifestações espíritas e afro-religiosas em acusações de: baixo espiritismo, exercício ilegal da medicina, macumba, candomblé ou magia negra.

Na década de 1940, o novo Código Penal, também admite repressões, ao impor regras ao funcionamento dos centros, como o estabelecimento de sede própria e não permitir a possessão nas sessões públicas. Isso demonstra o Estado interferindo, através das normas, nas formas de organização de manifestações religiosas.

A Constituição de 1988 assegura o princípio de laicidade do Estado, reconhece as manifestações afro-brasileiras e reconheceu a importância das religiosidades afro-brasileiros com o tombamento do terreiro da Casa Branca, localizado na Bahia. Também para garantir a liberdade de crença e coibir a intolerância religiosa, "o Código Penal de 1940 com a Lei n 9459/1997, considera crime a prática de discriminação ou preconceito contra religiões, como aponta no artigo 20; também consta no mesmo Código, no capítulo I Dos Crimes Contra o Sentimento Religioso, art. 208, punição ao ultraje a culto e impedimento de ato a ele relativo" (CAMPOS, 2014, p. 298).

Entretanto, apesar da laicidade e de um conjunto de leis assegurando a liberdade religiosa, ocorre uma persistência dos casos de intolerância religiosa, principalmente, contra as religiões de comunidades tradicionais de terreiro.

O advento das religiões neopentecostais proporcionou um aumento nos casos de intolerância religiosa contra as religiões de comunidades tradicionais de terreiro. 
Segundo Ari Pedro Oro (1997): "Estas religiões se utilizam dos meios de comunicação para divulgar a ideia de que a grande causa dos males deste mundo é atribuída à presença do demônio, o qual está associado aos deuses das religiões afro-brasileiras".

Antes de verificarmos essa batalha espiritual iniciada pelos neopentecostais contra as religiões de comunidades tradicionais de terreiro, devemos considerar as mudanças e as permanências no campo religioso brasileiro.

Para Silva (2007), esse ataque das religiões neopentecostais às religiões afro-brasileiras não é apenas uma estratégia para alcançar as populações de baixo nível socioeconômico, consumidoras desses repertórios religiosos, é consequência do papel das mediações mágicas e a experiência do transe religioso que se encontram entre os neopentecostais no contato com o repertório afro-brasileiro.

A mudança está na introdução neopentecostalismo no campo religioso brasileiro, as permanências estão no uso de elementos de outras religiões, ressemantizandos-os, como também numa exacerbação no uso de publicações no Brasil e até no exterior. Enfim, ressemantiza-se termos das religiões afro-brasileiras (trabalho, encosto, descarrego etc.) para sustentar seu discurso, ou seja, como Oro (2004) defende-se, um "neopentecostalismo macumbeiro".

Os efeitos do neopentecostalismo no campo religioso brasileiro atual foi a introdução de uma batalha espiritual utilizando um forte apelo midiático e político. Isso levou a um incremento dos casos de intolerância religiosa envolvendo ataques violentos aos praticantes das religiões de comunidades tradicionais de terreiro (SILVA, 2007).

A questão da intolerância religiosa contra as religiões de comunidades tradicionais de terreiro é um tema recorrente na mídia nacional, o crescimento 
vertiginoso dos casos de agressões, verbais ou físicas; as invasões de terreiros e tantas outras formas de intolerância tem diversas motivações e elas foram sistematizadas e organizadas, segundo alguns critérios, de acordo com Silva

\begin{abstract}
1) ataques nos cultos neopentecostais ou por divulgação proselitista; 2) invasões de terreiros e agressões físicas aos membros; 3 ) ataques às cerimônias religiosas afro-brasileiras realizadas no espaço público 4) ofensiva aos símbolos de herança africana ligados as religiões afrobrasileiras; 5) ataques perpetrados por políticos evangélicos ou por representantes dos interesses das igrejas na política; 6) as reações dos adeptos das religiões afro-brasileiras nas esferas políticas e judiciais; (SILVA, 2007, p. 10)
\end{abstract}

Dentro da questão relacionada às religiões neopentecostais, a divulgação proselitista e a Teologia da Guerra Espiritual, que, segundo Oro (2015, p.35), "foi desenvolvida nos Estados Unidos e foi adaptada à realidade cultural e religiosa brasileira". Os neopentecostais acreditam que estão livrando o Brasil das garras do demônio e de seus representantes aqui na terra, que seriam, no caso, as religiões mediúnicas, ou seja, as religiões afro-brasileiras e o kardecismo, pois para o principal representante da Igreja Universal do Reino de Deus (IURD) Edir Macedo, “a Umbanda, Quimbanda, Candomblé e o espiritismo de um modo geral, são os principais canais de atuação dos demônios, principalmente em nossa pátria" (MACEDO, 1987, p. 113)

$\mathrm{Na}$ intenção de buscarmos as razões para essa intolerância às religiões afrobrasileiras devemos entender como essas denominações modificaram o discurso no Brasil. De acordo com Silva (2015, p. 192), "O pentecostalismo surge no Brasil com a fundação em 1910 da Congregação Cristã, em São Paulo, e, no ano seguinte, da Assembleia de Deus, em Belém", caracterizavam-se como igrejas de dons carismáticos, o sectarismo e o ascetismo, conforme Mariano (2003, p. 31).

${ }^{5}$ SILVA, Vagner Gonçalves da. (Org.) Intolerância Religiosa: impactos do Neopentecostalismo no Campo Religioso Afro-brasileiro - 1. ed. .1. reimp. - São Paulo: Unesp, 2015, p.42. 
Ainda segundo Silva (2015), a questão dos malefícios causados pelas divindades do panteão afro-brasileiro já fazia parte desta etapa inicial do sistema teológico e doutrinário do pentecostalismo no Brasil.

A segunda etapa do movimento pentecostal ocorreu entre as décadas de 1950 e 1960, surgiram da Cruzada Nacional de Evangelização, liderada pela Igreja do Evangelho Quadrangular; a formação das igrejas: a Brasil para Cristo (São Paulo, 1955); Deus é Amor (São Paulo, 1962) e Casa da Benção (Belo Horizonte, 1964) assumindo características comuns a essas igrejas: cura divina e estratégias de proselitismo e conversão de multidões para Cristo.

Na terceira fase do movimento pentecostal, iniciada na década de 1970, é a fase "neopentecostal", pois, de acordo com Silva, ocorreu nessa etapa

\begin{abstract}
Abandono (ou abrandamento) do ascetismo, valorização do pragmatismo, utilização da gestão empresarial na condução dos templos, ênfase na teologia da prosperidade, utilização da mídia para o trabalho de proselitismo em massa e de propaganda religiosa (por isso chamadas de "igrejas eletrônicas") e centralidade da teologia da batalha espiritual contra as outras denominações religiosas, sobretudo as afro-brasileiras e o espiritismo (SILVA, 2007, p. 208)
\end{abstract}

Nas duas primeiras fases do pentecostalismo, devido à busca da cura divina para demonstrar o poder de Deus sobre as doenças, identificadas com o diabo, e, por consequência, com o candomblé e a umbanda, realizava-se a cura e o ritual da benção aos doentes. Contudo, Silva (2007, p. 195) aponta para o início do acirramento da batalha espiritual e da escolha das religiões afro-brasileiras na publicação do livro Mãe-de-santo (1968), do missionário canadense Walter Robert McAlister, fundador da Igreja Pentecostal de Nova Vida no Rio de Janeiro, em 1960. O prefacio do livro já indica a diferenciação no tratamento com as religiões afrobrasileiras 
Esta é a incrível história de uma baiana, cuja marca de faca, em seu braço direito, predestina-a desde o nascimento a ser mãe-de-santo, servindo os orixás e sacrificando aos exus a partir dos nove anos de idade. Nesta quarta edição, reestruturada, você vai sentir a repugnância experimentada por Georgina Aragão dos Santos Franco, ao ser enclausurada num quarto fétido, cheirando sangue seco, sangue este com que Ihe cobriram o corpo inteiro, ao "fazer o santo". Adivinhará depois toda sua alegria e euforia, quando finalmente descobriu não mais pertencer sua alma ao diabo, pois o sangue de Jesus Cristo passou a ser em sua vida mais forte e poderoso que quaisquer oferendas, vodos ou obrigações. Estou convencido de que você voltará muitas vezes a ler esse livro, como também o passará às mãos de amigos, parentes ou conhecidos que seguem as seitas afro-brasileiras. Aliás, este é um livro, que todo brasileiro deve ler (SILVA, 1983, p. 5) ${ }^{6}$.

A identificação de temas centrais da batalha espiritual por Silva (2015, p. 196) mostra-nos a conotação belicosa do missionário com as religiões de comunidades tradicionais de terreiro: "1) identificação das divindades do panteão afro com o demônio; 2) libertação pelo poder (maior) do sangue vivo de Jesus (em oposição ao sangue "seco" ou "fétido" da iniciação ou oferendas) e, em consequência da libertação; 3) a conversão."

Em um artigo sobre a IURD, Oro (2015, p. 37) enfatiza a aceitação do panteão afro-brasileiro pelos pastores da Igreja: "no que tange às entidades afrobrasileiras, a IURD não a nega, mas muda o seu significado." A demonstração de poder do pastor sobre os demônios é a principal arma de conversão e de manipulação dos estratos sociais que buscam a religião como forma de se protegerem das armadilhas do mal e das dificuldades atribuídas a ele.

O funcionamento de uma sessão de exorcismo da IURD, por exemplo, pode ser demonstrado em etapas: 1) invocação dos demônios; 2) manifestações nos fiéis dos demônios; 3) o pastor faz perguntas ao demônio e, geralmente, recebe como resposta que são exus ou pombagiras. Além da identificação, o demônio responde

${ }^{6}$ SILVA, Vagner Gonçalves da. (Org.) Intolerância Religiosa: impactos do Neopentecostalismo no Campo Religioso Afro-brasileiro - 1. ed. .1. reimp. - São Paulo: Unesp, 2015. p.195 
sobre o mal que está proporcionado à vida daquela pessoa; e finalmente, 4) ocorre a expulsão do demônio.

No entanto, a obra que mais demoniza as religiões afro-brasileiras pertence ao principal líder da IURD, Edir Macedo, o livro Orixás, Caboclos e Guias: deuses ou demônios, onde Silva menciona uso das imagens de uma iniciação no candomblé para depreciá-la e atemorizar o leitor sobre a ritualística demoníaca dos candomblecistas

Mas o impacto maior decorre da reprodução fotográfica de inúmeras cenas de rituais secretos de uma iniciação, como o orô (momento do sacrifício do animal sobre a cabeça do iniciado). Essas cenas são, de fato, o "calcanhar de Aquiles" dos cultos afros, sobretudo quando retiradas de seu contexto, visando criar a imagem dessas religiões como "sangrentas", "selvagens" ou "primitivas" (SILVA, 2015, p. 202).

Para piorar a situação o autor do livro Orixás, Caboclos e Guias associa o sacrifício ritual do candomblé ao crime e a magia negra como demonstra

\begin{abstract}
Entretanto, seu autor está convencido que as religiões afro-brasileiras estão por trás de todas essas manifestações, daí colocar fotos de pessoas assassinadas como animais em rituais (tendo o corpo coberto por sangue) e de pessoas deitadas num quarto de iniciação (tendo sobre o corpo o sangue ritual dos animais) (SILVA, 2015, p. 203).
\end{abstract}

A questão de usar imagens para chocar as pessoas sobre algo terrível, espantoso ou desumano virou rotina nas redes sociais e nas mídias em geral. Neste caso, percebemos uma exacerbação no uso de imagens e de notícias sensacionalistas para provocar repulsa ou condenação de minorias, como no caso do candomblé e de sua iniciação que foi demonizada pelo líder da IURD em seu livro Orixás, Caboclos e Guias: deuses ou demônios.

Contudo, o sacrifício não tem a função de comunicação com demônios, como declara Silva

Nas religiões afro-brasileiras o simbolismo do sacrifício animal representa a "morte" da vida anterior da iniciada e o seu nascimento para uma vida nova com e no seu orixá. Pela morte do animal, homens e deuses se aproximam (SILVA, 2015, p. 228). 
Sobre sacrifício e a relação entre animais, humanos e o divino Silva define que

$\mathrm{Na}$ constituição da pessoa humana em contato com o divino podemos concluir, portanto, que catolicismo, neopentecostalismo e candomblé enfatizam termos diferentes de uma mesma tríade formada por homens, deuses e animais. No primeiro, celebra-se a morte do Cordeiro de Deus em nome dos homens; no segundo, a morte do demônio nos homens por meio do sangue do Cordeiro; no candomblé, a morte dos animais (cordeiros) em nome dos deuses e dos homens (SILVA, 2015, p. 229).

Ao acreditarem que o mundo está desorientado e rodeado pelos demônios, os neopentecostais creem que a qualquer custo devem batalhar contra o mal e as suas hostes devem ser vencidas, rapidamente, sem dó ou piedade para com os serviçais do inimigo, como declara Silva (2015, p. 12): "Insuflados por essa crença membros das igrejas neopentecostais muitas vezes invadem terreiros visando destruir altares, a quebrar imagens e a "exorcizar" seus frequentadores, o que geralmente termina em agressão física".

As festas em locais públicos é um problema maior para os fiéis das religiões de comunidades tradicionais de terreiro e neste caso Silva relata

Quando as atividades religiosas (festas de orixá, oferendas, procissões etc.)
são feitas em lugares públicos (praias, matas, cachoeiras, ruas, largos e
ginásios), os adeptos ficam mais expostos a ataques, que englobam desde
a simples distribuição aos presentes de panfletos com propaganda contra
esses cultos até a tentativa de interrupção forçada dos rituais (SILVA, 2015,
p. 14).

Nos espaços públicos, o transe, ao qual o fiel das religiões afro-brasileiras está submetido é muitas vezes motivo de deboches por parte dos transeuntes que não entendem o que significa e não veem que o outro está em sua prática religiosa. Até os próprios neopentecostais e outras denominações cristãs quando professam, também, a sua fé em local público, sofrem com os deboches e olhares negativos quanto à expressão de fé ao público. Tudo isso demonstra uma crescente onda de intolerância religiosa no Brasil. 
Os símbolos da herança africana, as africanidades, mesmo que não tenham referência nas religiões afro-brasileiras, passaram a ser rechaçados e combatidos. $O$ samba passou a ser malvisto e escola de samba é a "escola do capeta", de acordo com Silva (2015) "Informação de Leandro Braga, maestro dirigente da organização na lista de discussão Samba e Choro, 2004 (www.samba-choro.com.br)". A desqualificação dos símbolos e sua apropriação pelos evangélicos, também, é uma forma de retirar a ancestralidade e a espiritualidade africana como no caso da capoeira, Silva (2015, p. 15) relata: "capoeira de Cristo, evangélica ou gospel, em cujas letras não há referências aos orixás ou santos católicos."

Em outro caso temos outra apropriação e utilização de símbolos da herança africana de acordo com Silva

\begin{abstract}
Outro exemplo é o "acarajé do Senhor", feito por mulheres evangélicas que querem dissociar esse alimento das religiões afro-brasileiras (o acarajé é uma comida votiva de lansã) e da imagem das baianas que tradicionalmente $\mathrm{o}$ comercializam vestidas com suas saias brancas $\mathrm{e}$ colares de contas (guias), uma indumentária típica dos terreiros e conhecida nacionalmente (SILVA, 2015, p. 16).
\end{abstract}

A divergência sobre a inclusão da temática "História e Cultura Afro-brasileira" e a inclusão de materiais didáticos relacionados as religiões afro-brasileiras para abordar a questão da tolerância religiosa, da diversidade cultural, da laicidade, do humanismo e da alteridade. As polêmicas sobre a escolha do material didático que na época foi recomendado pelo MEC narra casos polêmicos sobre a "Coleção História Paratodos, Ensino Fundamental, editora Scipione, de autoria de Maria da Conceição Carneiro de Oliveira", principalmente

No volume indicado para a segunda série, no capítulo "Nossas Raízes Africanas", a autora trata da formação das religiões afro-brasileiras, inclusive com exercícios pedindo para as crianças pesquisarem sobre a história dos orixás. Uma coordenadora pedagógica evangélica de Belfort Roxo, Rio de Janeiro, protestou junto à editora alegando que o livro fazia apologia das religiões afro-brasileiras e que não seria adotado em sua escola, onde a maioria dos alunos e professores, segundo ela, era 
evangélica. A mesma coleção também gerou protesto na Câmara da cidade de Pato Branco, Paraná, onde um vereador e pastor evangélico denominou a obra de "livro do demônio" e pediu a cassação da coleção (SILVA, 2015, p. 16/17).

A coleção foi "recomendada pelo Guia do Plano Nacional do Livro Didático (PNLD-2004)". Essa situação gerada pelo inconformismo de determinados cidadãos que professam a fé evangélica e se sentem prejudicados quando é abordado a temática da História e Cultura Africana e Afro-brasileira denota a força proselitista dos evangélicos, a indisposição com a nossa própria história, ou seja, não aceitamos a nossa própria condição multiétnica e, portanto, somos racistas e aceitamos a teoria da batalha espiritual, vendo o demônio em tudo e em todos.

Sobre as candidaturas evangélicas, de seus aliados e do apoio aos mesmos a causas antagônicas ao campo afro-brasileiro, como, por exemplo, Silva relata

No Rio Grande do Sul, por pressão desses políticos e com o apoio das sociedades protetoras dos animais, o Código Estadual de Proteção aos Animais tem sido acionado na tentativa de coibir os sacrifícios rituais do candomblé (SILVA, 2015, p. 17).

Diante dos ataques, as reações dos fiéis afro-brasileiros que eram inexpressivas têm crescido, o que não é um movimento articulado, com representação política e de comunicação de massa, para frear ou diminuir os impactos negativos do proselitismo neopentecostal via igrejas eletrônicas.

Ocorre a formação de movimentos de defesa das religiões afro-brasileiras e ações na Justiça de babalorixás e das lalorixás contra pastores e as suas igrejas.

O caso de mãe Gilda foi observado por Silva

Gilda (Gildásia dos Santos e Santos), do Axé Abassá de Ogum, em Itapuã, Bahia, que em 1992 participou em Brasília de um protesto contra o governo Collor, tendo sido fotografada pela revista Veja ao lado de um despacho ${ }^{7}$. Posteriormente, essa imagem foi usada numa edição de 1999 da Folha Universal8 (publicação da IURD) ao lado da manchete "Macumbeiros

\footnotetext{
${ }^{7}$ Nota 31. Veja 26.9.1992.

${ }^{8}$ Nota 32. Folha Universal, ano VII, n.390, set-out 1999.
} 
Charlatões Lesam a Bolsa e a Vida dos Clientes - O Mercado da Enganação Cresce no Brasil, mas o Procon Está de Olho (SILVA, 2015, p. 20).

A situação deteriorou-se quando ocorreu a invasão do terreiro por um grupo da Igreja Deus é Amor, de acordo com o autor

Este fato e a invasão de seu terreiro por membros da Igreja Deus é Amor, que tentaram "exorcizá-la", levaram a mãe-de-santo a decidir pela ação judicial contra seus agressores e difamadores. Mãe Gilda faleceu em seguida, aos 65 anos, de um infarto fulminante, em consequência, segundo sua família, desses acontecimentos, que a abalaram profundamente ${ }^{9}$ (SILVA, 2015, p. 20).

O impasse foi resolvido conforme relata Silva

Em 2004, a Justiça condenou a Igreja Universal e sua gráfica a indenizar a família da ialorixá em 1,372 milhões de Reais pelo uso indevido de sua imagem (um Real por cada exemplar do jornal publicado com a matéria) ${ }^{10}$. O caráter emblemático deste caso levou nesse mesmo ano a Câmara de Vereadores de Salvador a transformar a data de falecimento da ialorixá, 21.1.2000, em "Dia Municipal de Combate à Intolerância Religiosa (SILVA, 2015, p. 20/21).

A necessidade de reação frente aos ataques intolerantes e a sua lógica perversa de perseguir o povo de santo tem levado à superação das divergências entre candomblecistas e umbandistas e, também, entre as nações, como os candomblés queto e angola.

A busca de um ecumenismo, ou seja, de um movimento ecumênico tem sido uma saída estratégica de resistência do povo de santo aos ataques intolerantes. Como salienta Silva (2015, p. 23): "Por meio desse movimento ecumênico, os cultos afro-brasileiros podem, inclusive, encontrar a solidariedade de igrejas evangélicas

\footnotetext{
${ }^{9}$ Nota 33 A Tarde, 7.7.2005.

${ }^{10}$ Nota 34 Em 2005, a sentença proferida em julgamento de segunda instância reduziu este valor para 960 mil Reais o teto praticado pelo Tribunal de Justiça do Estado (A Tarde, 12.1.2003; 7.7.2005)
} 
que discordam e condenam os ataques realizados pelas denominações neopentecostais mais intolerantes ${ }^{11 "}$.

O problema da intolerância religiosa ao povo de santo no país da crença do mito da igualdade racial, não podemos esperar outra coisa que ataques aos fiéis das religiões afro-brasileiras e tudo sob supervisão das autoridades estabelecidas no atual contexto de intolerância, preconceito, racismo e muitas formas de opressão das minorias no Brasil.

De acordo com Junior (2015, p. 303) "a intolerância religiosa que historicamente se abate sobre as religiões afro-brasileiras conforma uma das facetas do racismo brasileiro". A Justiça no Brasil Colônia defendia o escravagismo, não tolerava a negação de Deus, punia a feitiçaria e coisificava o escravo. Após a Independência do Brasil, na fase imperial, proibia-se o ensino no primário e secundário ao escravo no Município da Corte e punia a celebração, propaganda ou culto de confissão religiosa que não fosse a oficial (Igreja Católica). No período republicano, em sua fase inicial, punia os crimes de capoeiragem, curandeirismo e espiritismo. No Código Penal de 1940 foram mantidos os delitos de curandeirismo e charlatanismo.

De acordo com Silva

Enfim, o desenvolvimento das religiões afro-brasileiras foi marcado pela necessidade de criar estratégias de sobrevivência e diálogo frente às condições adversas. Foram perseguidas pela Igreja Católica ao longo de quatro séculos, pelo Estado republicano, sobretudo na primeira metade do século $X X$, quando este se valeu de órgãos de repressão policial e de serviços de controle social e higiene mental, e, finalmente, pelas elites sociais num misto de desprezo e fascínio pelo exotismo que sempre esteve associado às manifestações culturais dos africanos e seus descendentes no Brasil. Entretanto, desde pelo menos a década de 1960, quando essas religiões conquistaram relativa legitimidade nos centros urbanos, resultado dos movimentos de renovação cultural e de conscientização política, da

\footnotetext{
${ }^{11}$ Nota 42. Sobre esse aspecto é interessante consultar o "Relatório Elaborado pela Igreja Presbiteriana do Brasil. Visando o Esclarecimento de seus Membros Referentes à Fé e Prática da Igreja Universal do Reino de Deus." (http://www.cacp.org.br/iurd.htm)
} 
aliança com membros da classe média, acadêmicos e artistas, entre outros fatores, não se tinha notícia da formação de agentes antagônicos tão empenhados na tentativa de desqualificação. Portanto, ainda que incipiente, a união de religiosos afro-brasileiros, movimento negro, ONGs, acadêmicos, pesquisadores, políticos, advogados, promotores públicos, entre outros, parecem apostar mais uma vez na capacidade de resistência e reação dessas religiões contra um assédio proporcionalmente muito mais eficaz e, a julgar por seu estado atual e crescimento numérico, duradouro (SILVA, 2015, p. 23/24).

As religiões de comunidades tradicionais de terreiro estão mais propensas à atuação de pessoas de fora do seu meio religioso que contribuam para a sua aceitação como expressão religiosa, legalmente, como escreve Junior

A Constituição de 1988 imprime ao Estado um caráter rigorosamente laico, vedando, em seu art. 19, inciso I, que o mesmo, de um lado, estabeleça alianças ou relação de dependência com qualquer culto; e, de outro, que embarace o funcionamento de culto de qualquer natureza (JUNIOR, 2015, p. 313).

Na questão dos direitos e garantias fundamentais da Constituição de 1988,

fica estabelecido, de acordo com Junior

Não é demais lembrar que as associações constituídas com a finalidade de promover o culto religioso são tuteladas por vários dispositivos do famoso art. $5^{\circ}$, dos direitos e garantias fundamentais.

$\mathrm{O}$ mesmo art. $5^{\circ}, \mathrm{VI}$, consagra o princípio da liberdade de crença, da liberdade de culto e da liberdade de liturgias e de organização religiosa, insertas no catálogo constitucional das liberdades públicas, sendo que o Supremo Tribunal Federal há muito fixou o entendimento segundo o qual a decisão sobre a organização religiosa insere-se nas prerrogativas privativas da autoridade religiosa. Corolário da liberdade de crença, a disciplina do ensino religioso, embora prevista no texto constitucional, foi condicionada pela matrícula de caráter facultativo, consoante preconizado no art. $210, \S$ $1^{\circ}$. Ademais, depurando o alcance da liberdade de crença, o art. $5^{\circ}$, inciso VIII, proíbe a privação de direitos fundada em credo religioso, (...) (JUNIOR, 2015, p. 313).

Aqui, o autor deixa claro que há outros elementos de defesa do povo de santo, além do remédio constitucional

- O Código Penal, que pune o ultraje a culto e impedimento ou perturbação de ato a ele relativo (art. 208).

- O Código de Processo Penal, que inscreve o ministro religioso no elenco das pessoas às quais é deferido o direito à prisão especial (art. 295).

- A lei n. 4898/65, que pune o abuso de autoridade decorrente de atentado à liberdade de associação, à liberdade de consciência e de crença e ao livre exercício de culto religioso (art. 4, alíneas "d" e "e"). 
- A lei n. 7716/89, que pune a prática, a incitação e a indução à discriminação ou ao preconceito por motivo de religião, entre outros (art. 20).

- A lei n. 8212/91, que equipara, para fins previdenciários, o ministro religioso aos trabalhadores autônomos (art. 12, inciso V, alínea "c") (JUNIOR, 2015, p. 313/314).

A intolerância não terá freios se a aplicação das leis for branda com aqueles que praticam atos intolerantes. Portanto, os legisladores deverão impor leis mais rígidas aos intolerantes de qualquer denominação religiosa. Um exemplo dessa união contra a intolerância religiosa foi, de acordo com Oro,

O episódio do "chute na santa" - o "chute" desferido pelo pastor da Igreja Universal Sergio Von Helder contra a imagem de Nossa Senhora Aparecida, em 12 de outubro de 1995 - mobilizou a seu favor, sem grande esforço, a mídia e inúmeros segmentos da sociedade nacional12 (ORO, 2015, p. 51)

\subsection{O CANDOMBLÉ}

Os terreiros transformaram-se em núcleos privilegiados de encontro, lazer e solidariedade para negros, mulatos e pobres em geral, neste espaço afirmaram a sua identidade cultural. Nesses espaços, também, defenderam-se da exclusão e perseguição, aos quais os sofriam os ex-cativos e os marginalizados da sociedade excludente construída pelos governantes da República oligárquica.

A família-de-santo é a forma de organização dos terreiros e isso foi passado pela da tradição oral do candomblé.

$\mathrm{Na}$ iniciação a pessoa passa a pertencer a um terreiro e de sua família-desanto, assume um nome religioso (africano) e um compromisso eterno com seu deus pessoal e ao mesmo tempo com seu pai ou mãe-de-santo (SILVA, 2005).

\footnotetext{
12 Nota 30 F. Pierucci assinala que não é todo conflito religioso que provoca uma controvérsia pública e envolve uma grande diversidade de atores sociais como o chamado "chute na santa". Nele envolveram-se "além de jornais e jornalistas, entre outros intelectuais da informação, escritores, produtores e divulgadores culturais, apresentadores de programas de rádio e televisão, músicos, bandas de pop music, rock, rap e carnaval, novos play leaders, humoristas, atores e outros profissionais das artes e espetáculos, juristas, juízes, corregedores, representantes do ministério público, sociólogos, antropólogos, comentaristas políticos, assistentes sociais, psicanalistas, médicos, terapeutas, líderes sindicais etc. A lista é pós-moderna" (Pierucci, 1996, p. 281). Para um inventário das matérias publicadas na imprensa brasileira sobre o episódio "chute na santa'. Ver A. Corten, 1996, p. 217.
} 
A organização social dos terreiros estruturou-se através de uma hierarquia de cargos e funções que foi refeita para reunir, num mesmo local, diferentes modelos de religiões africanas.

Já a organização espacial dos terreiros reuniu local de moradia e de religiosidade em um mesmo espaço, reinventou, em escala pequena, os padrões africanos. Na África as habitações coletivas, principalmente dos iorubas, recebiam o nome de egbes ou compounds. O compound era um conjunto de casas pequenas construídas lado a lado na forma de quadrado ou retângulo, as portas e janelas ficavam voltadas para o pátio interno do conjunto.

No terreiro de candomblé os negros reproduziram no nível mítico alguns desses padrões de moradia e de religiosidade. Exu continuou guardando a entrada e os demais orixás, com seus quartos individuais, sintetizaram a divisão de práticas por família. No barracão do terreiro funcionava o encontro religioso e as festas públicas, reproduzindo o pátio interno do compound (SILVA, 2005).

No candomblé, a nação, numa alusão significativa de que os terreiros, além de tentarem reproduzir os padrões africanos de manifestações, possuíam uma identidade grupal (étnica) como nos reinos da África.

Os sudaneses predominaram no século XIX, época de mudanças das condições urbanas e diminuição das perseguições às religiões. Já no período colonial, os bantos foram majoritários e sofreram com os rigores das perseguições religiosas. Desse processo resultaram dois modelos de manifestações: o rito jejenagô e o angola.

O rito jeje-nagô abrange as nações nagôs (queto, ijexá etc.) e as jejes (jejefon e jeje-marrin), enfatiza o legado das religiões sudanesas. 
Nos terreiros, onde o rito jeje-nagô é praticado, geralmente cultuam-se orixás, voduns, erês (espíritos infantis) e caboclos (espíritos indígenas). Onde prevalece o culto aos orixás são conhecidos como candomblé queto; os de culto aos voduns são os candomblés jeje.

Nos terreiros partidários da "pureza" ritual, a religiosidade dos caboclos e o sincretismo com os santos católicos é malvisto e em muitos casos abolido. Nessa nação os atabaques são percutidos com varinhas (os aguidavis) e as canções para os orixás são realizadas em dialeto africano.

No rito angola, o cerimonial congo cabinda enfatiza a herança das religiões bantos. Nessa nação, cultua-se os inquices (deuses dos bantos), os orixás, os voduns, os vunjes (espíritos infantis) e os caboclos. No candomblé angola, os atabaques são percutidos com as mãos e as cantigas possuem muitos termos em português (SILVA, 2005).

A questão da ancestralidade africana, como critério para pertencer à religião, foi abolida, e os orixás tornaram-se deuses adorados por toda uma população que passou a tê-los como entidades espirituais regentes, independentemente de sua cor ou origem (SILVA, 2005).

O resgate das africanidades presente no candomblé e a busca de uma tradição e legitimidade, conforme Gonçalves e Oliveira (2011), tem deixado as religiões sincretizadas e assimiladas desprestigiadas pelo apreço ao berço da tradição africana que é motivo de busca do movimento negro como construção da identidade negra e africana na atual formação do mercado religioso de comunidades tradicionais de terreiro.

Continuando os esclarecimentos sobre as questões das nações no candomblé devemos utilizar os escritos de Batista para fornecer o embasamento 
teórico necessário para a estruturação da diversidade religiosa de comunidades tradicionais de terreiro e a sua formação

No processo de organização dos agrupamentos e casas de santo do candomblé no Brasil, o termo empregado para a identificação desses agrupamentos religiosos que surgiram das aglutinações que se referiam às suas origens era "nação". Nas relações endógenas às casas de santo e nações do candomblé, nação é um termo tradicionalmente mais antigo que comunidade. A maior utilização do termo nação demonstra, em especial, também as diferenças religiosas e políticas entre os agrupamentos de candomblé, como angola, jeje e ketu. No entanto, para efeito das relações recentes com o poder público, comunidade é um termo jurídico e político que favorece tais relações, enquanto o termo nação implica numa ideologia de concorrência das nacionalidades africanas com as ideologias do nacionalismo brasileiro (BATISTA, 2014, p. 36).

A nação está ligada a origem do africano e a sua classificação de acordo com a região étnica para identificação do escravizado aqui no Brasil. A busca das raízes do candomblé por Morais está evidenciada

No candomblé, a maneira de cultuar as divindades foi distinguida pelos negros de acordo com os modelos de rito classificados como nação, numa alusão aos grupos étnicos africanos (Lima, 1974). Para o Brasil, foram trazidos negros que viviam em localidades de duas regiões subsaarianas. Da região que engloba toda a área abaixo da linha do Equador vieram os bantos, e da região que vai do Senegal à Nigéria, no Golfo do Benin, ou seja, a África Ocidental, vieram os iorubás. Esses últimos predominaram no tráfico negreiro durante o século XIX. Deles surgiram as nações de candomblé nagô (como queto, ijexá) e jeje (como jeje-fon, jeje-marrin). Os grupos bantos forma maioria durante o período colonial e deram origem às nações de rito angola (como angola-congo, moxicongo). Das nações angola, nagô e jeje, os termos adotados - seja o nome das divindades ou de rituais - nos terreiros nagôs são os mais conhecidos (MORAIS, 2000, p. 34).

Para enfatizar o reconhecimento e a diferença de religiões, a autora evidencia

as nações e as linhagens e todo o processo de reconstrução de uma África mítica, cultuada e transformada na família de santo que identifica e revaloriza o filho ou filha afiliados aos respectivos terreiros que Ihes proporciona identidade, valorização e um constante aprendizado nos mistérios e no recebimento do axé

Enquanto na África os orixás eram cultuados por pessoas de um mesmo grupo ou família, no Brasil a relação de parentesco sofre alterações. Por meio do processo de iniciação, os devotos ficam ligados por laços de 
parentesco mítico. Cada terreiro distingue-se do outro pela nomenclatura baseada em diferenças rituais e pelo vocabulário africanizado usado em cerimônias e atividades cotidianas. Esses rótulos diferenciadores são as nações, que aludem às possíveis ligações com o continente africano. Ao termo linhagem pode ser dado o significado de árvore genealógica. Se uma pessoa pertence a um terreiro, ela pertence a uma linhagem, a uma família de santo, que é a família espiritual formada dentro de cada terreiro. Um pai ou mãe de santo, ou seja, a pessoa que o iniciou no candomblé. Apesar desse pertencimento, os terreiros atuam de forma autônoma. Em uma casa de candomblé a autoridade máxima é o pai ou a mãe de santo. Mesmo as entidades representativas dos terreiros, como associações e federações, não interferem nas casas de culto. Essas entidades visam a defesa coletiva dos terreiros (MORAIS, 2000, p. 37).

\subsubsection{Os Orixás}

As religiões africanas tinham em comum a crença num ser supremo, chamado Olodumarê entre os iorubas, de Mavu e Lissa entre os jejes e de Zambi entre os bantos. As semelhanças entre os deuses africanos e entre estes e os santos católicos deu origem aos sincretismos, de acordo com Silva (2005).

Exu é uma das figuras mais controvertidas do panteão das religiões dos afrodescendentes e o mais humano dos Orixás.

Exu é o orixá mensageiro entre os homens e os deuses. Na África, está associado ao poder da fertilização e à força transformadora das coisas. O ogó é o instrumento de madeira esculpido em forma de pênis e adornado com cabaças e búzios que representam os testículos e o sêmen, segundo Silva (2005).

"O dia de Exu é a segunda-feira, dia das almas no calendário católico. A sua comida preferida é o galo, farofa de dendê, pimenta e cachaça” (SILVA, 2005, p. 71). A manifestações religiosas a Exu era visto como demoníaco pela Igreja já na África e no Brasil colonial. Essa divindade foi associada ao demônio, devido a sua imagem com chifres, rabo e patas de bode. "No rito jeje o deus mensageiro é Elebará e no rito angola é Aluviá (masculino) e Pombagira (feminino)" (SILVA, 2005, p. 71). 
Ogum é o orixá da guerra e do fogo, também era ferreiro e herói civilizador africano devido ao conhecimento dos segredos da forja necessários para a fabricação de instrumentos metálicos para a agricultura, bem como, as armas de guerra. Seus símbolos são a espada e ferramentas como a enxada e a pá.

No seu mito, segundo Silva (2005), Ogum era filho do rei Odudua, que fundou Ifé, cidade responsável pela expansão e divulgação da cultura iorubana no continente africano. No Brasil, é associado a Santo Antônio e a São Jorge (Rio de Janeiro). No rito jeje, é o vodum Doçu, também sincretizado com São Jorge. No rito angola, é Inconce ou Roxo Mucumbe.

"Oxóssi é o orixá da mata. Caçador, retira dela seu sustento e o de sua tribo. $\mathrm{Na}$ África era cultuado pelas famílias reais da cidade de Keto, na qual fora rei" (SILVA, 2005, p. 72). No rito jeje é Azacá. No rito angola é Mutacalombo e Congombira. Na Bahia, Oxóssi foi sincretizado como São Jorge. No Rio de Janeiro com São Sebastião, e, em Pernambuco é associado a São Miguel.

Obaluaiê ou Omulu ou Xapanã é o temível orixá das epidemias, da varíola e demais doenças contagiosas e de pele. Segundo, Silva (2005) é um orixá muito temido no Brasil, devido ao temor de espalhar doenças, e, também, de permitir a cura. Trazendo as marcas das doenças no próprio corpo e por este motivo veste-se com chapéu em forma de manto feito de palha-da-costa para que ninguém veja seu corpo. O sincretismo mais frequente e de São Lázaro como também São Roque. No rito jeje é Acossi Sapatá e no rito angola, Cavungo e Cafunã.

Ossaim é o grande sacerdote das folhas, grande feiticeiro, que por meio das folhas pode realizar curas, trazer progresso e riqueza. Esse orixá é fundamental no Candomblé, visto que sem folhas, sem a sua presença, nenhuma cerimônia pode 
realizar-se, pois ele detém o axé que desperta o poder do "sangue" verde das folhas $^{13}$.

Para Silva (2005), Ossaim é o deus das folhas, das ervas e dos medicamentos feitos a partir delas. Seu domínio é a mata e o seu culto tem papel fundamental no candomblé devido a importância das folhas. Divindade que possui apenas uma perna, Ossaim foi associado com alguns "encantados", como caipora e o saci-pererê. No rito angola o Inquice das folhas é chamado Catendê e no rito jeje é Aguê. O sincretismo de Ossaim no catolicismo é variado: São Benedito, São Roque e São Jorge.

Xangô é o orixá que em sua vida na terra foi o rei de Oyó, que, de acordo com Silva (2005), era uma das principais cidades iorubanas. É o senhor dos raios e do trovão, que solta fogo pela boca. Seu símbolo é o machado de duas faces e a coroa. Associado a São Jerônimo que tem aos pés um leão, símbolo da realeza entre os iorubás. No rito jeje o vodum Badé-Quevioso controla os astros, os raios, trovões e tempestades. No rito angola é Zaze. É sincretizado por São Pedro, o "porteiro do céu" (SILVA, 2005, p. 78).

Oxum, para Silva (2005), é a deusa da água doce, lagos, fontes e cachoeiras. $\mathrm{Na}$ África está relacionada a fertilidade das mulheres e a subsistência das comunidades. É sincretizada por Nossa Senhora da Conceição. No rito jeje é Eowa ou Aziritoboce, já no rito angola é Quissambo ou Samba.

lemanjá é a deusa das águas, mãe de todos os outros orixás. "Na África era divindade de um rio, porém, para fugir do marido, desembocou no mar, onde vive com sua mãe Okun" (SILVA p. 78). No Brasil é cultuada no mar e associada aos "encantados" das águas, de origem indígena. É a Rainha do Mar, Janaína, Mãe

\footnotetext{
${ }^{13}$ Disponível em: $<$ https://ocandomble.com/os-orixas/ossaim/>
} 
D’água, Sereia, lara etc. No rito jeje é Abé e no rito angola Mãe Danda (Dandalunda) ou Quissimbe. Sincretismo com Nossa Senhora e festa e louvações em datas variadas.

"lansã ou Oyá a deusa dos ventos, raios e tempestades, domínio que divide com seu marido Xangô" (SILVA, 2005, p. 79). O culto dos mortos (egungun) está relacionado a lansã. A devoção às almas está presente no catolicismo popular e religiosidade africana. Está associada a Santa Barbará. No rito jeje é Sobô e no rito angola Bumburucema ou Matamba

“Oxalá orixá da criação. Modelou com o barro o corpo dos homens sobre o qual Olodumarê (O Ser Supremo) soprou para dar vida" (SILVA, 2005, p. 80). Oxalá foi designado por Olodumarê para criar todo o mundo e recebeu o "saco da criação" e o poder de realização (axé). No entanto, esqueceu-se de fazer as oferendas a Exu que vingou provocando-Ihe uma enorme sede. Desesperado, ele se embriaga com vinho de palmeira e adormece.

Olodumarê designa Odudua, que espalha a substância do saco da criação sobre a superfície da água até formar um monte. Neste monte uma galinha foi ciscando e espalhando terra até cobrir a superfície das águas e foi formada a cidade de Ifé. Oxalá é associado a Jesus, filho do criador. Na Bahia e feita a lavagem da Igreja de Senhor do Bonfim este sincretismo está relacionado ao mito da visita do velho Oxalá a seu amigo Xangô, rei de Oyó. De acordo com Silva (2005) no rito jeje a criação foi realizada por Mavu (princípio feminino) e Lissa (princípio masculino). Já para os angolas, ainda, para o autor a criação ficou a cargo de Zambi ou Lemba. 


\title{
2.5. VARIAÇÕES REGIONAIS NAS RELIGIÕES AFRO-BRASILEIRAS
}

As variações regionais do rito jeje-nagô, são, de acordo com Silva (2005): Candomblé da Bahia; Batuque do Rio Grande do Sul e o Xangô de Pernambuco. Todos eles receberam a influência iorubá. No entanto, realizaram adaptações e influências locais.

O Tambor-de-Mina encontra-se nas regiões do Maranhão e do Pará, foi; segundo Silva (2005), criado por influência dos jejes. Ainda para o autor o nome mina é devido a referência a origem dos escravos, que ficavam aguardando o embarque nos navios negreiros em um forte português chamado São Jorge da Mina, localizado na África Ocidental. Os praticantes do Tambor-de-mina cultuam os voduns, divindades jejes, assim como os "encantados". Na Casa das Minas, terreiro fundado em São Luís do Maranhão, na metade do século XIX, os voduns são cultuados respeitando as famílias mitológicas a que pertencem, como deixa claro Silva

\begin{abstract}
A família Davice é formada pelos voduns chamados nobres (reis e rainhas) da corte real do Daomé. É considerada a principal família mitológica do terreiro e hospeda as demais: a família de Savaluno (constituída pelos voduns adorados na região ao norte do Daomé); a família Dambirá (a dos voduns da terra, das doenças e da peste); e a família de Quevioso e de Aladanu (a dos voduns dos raios, dos trovões, do ar e das águas). Esta última família é considerada de origem nagô (iorubá) pelos jejes, por os voduns que a ela pertencem, quando incorporam alguém, não falam, pois teme-se que se eles falassem revelariam segredos dos nagôs aos jejes (SILVA, 2005, p. 84).
\end{abstract}

Há, nos rituais da Casa das Minas, a devoção aos santos católicos, de acordo com Silva (2005), os membros do terreiro, antes das homenagens aos deuses africanos, rezam ladainha para os santos. Os santos não falam e não incorporam.

Às divindades não-africanas, também, são dedicadas as práticas dos praticantes do tambor-de-mina, que, segundo Silva, são 
(...) os "encantados" de diversas origens míticas: os caboclos da mata (como Tabajara e Corre-Beirada); os fidalgos ou nobres portugueses e franceses (como Rei Sebastião e Dom Luís, rei de França); e os turcos ou mouros (como Rei da Turquia). O culto a esse vasto panteão também é chamado de tambor-da-mata ou terecô e geralmente é visto, pelos praticantes do culto aos voduns, como uma reprodução imperfeita das práticas religiosas jejes mais ortodoxas, onde apenas o culto às divindades africanas é admitido, como na Casa das Minas (SILVA, 2005, p. 84/85 apud FERRETI, M, 1993).

Na região do Pará, as práticas aos voduns e das entidades da mata, ainda segundo o autor, tem o nome de babassuê, batuque-de-Santa-Barbará ou barbasuêra, devido a importância da santa que é a padroeira de muitos terreiros.

Cabula influência das práticas bantos, região do Espírito Santo. Pra Silva (2005), segundo análise do bispo D. Nery, a cabula era praticada por negros e contava com a presença de alguns brancos. A manifestação religiosa parece ter desaparecido, formando outras denominações. O ritual era em alguma residência ou nas matas e era denominada de mesa, nas quais as principais a de Santa Maria e Santa Bárbara. O responsável pela mesa era o embanda e os auxiliares eram os cambones. Os adeptos eram chamados de camanás e a reunião era conhecida por engira.

As reuniões eram secretas e feitas à noite, os praticantes da cabula usavam roupas brancas e dentro da mata, preparavam uma mesa e faziam uma fogueira. Cantos preparatórios pediam licença aos espíritos. Nos ritos utilizavam vinho, mastigava-se raiz e aspirava o fumo do incenso. Aos que passariam pela iniciação utilizava-se o ritual de passar três vezes por debaixo das pernas do embanda, para confirmar a obediência ao novo pai. Emba, era um pó sagrado, que serviria para a limpeza espiritual e preparar para o local para a tomada do Santé, ou seja, o recebimento do espírito protetor. A prova do iniciado para ter um Santé era entrar na mata com uma vela apagada e voltar ela acesa, sem ter usado de meios para 
acendê-la, e não era apenas a vela acesa, deveria trazer, também o nome do espírito protetor. Para concluir (SILVA, 2005, p. 86) finaliza com a descrição de Nery: "Alguns desses espíritos eram conhecidos como Tatá Guerreiro, Tatá flor da Carunga, Tatá Rompe-Serra e Tatá Rompe-Ponte (cf. NERY, 1963)”.

Macumba do Rio de Janeiro, de acordo com Silva (2005), ela aproximava-se da cabula, tanto que o responsável pela prática era conhecido por embanda, umbanda ou quimbanda, ou auxiliares, cambono ou cambone. As iniciadas eram chamadas de filhas-de-santo, devido à influência do rito jeje-nagô, ou médiuns, dado a contribuição do kardecismo. Nas sessões de macumba procurava-se cultuar o maior número de linhas possível, quanto maior o conhecimento do pai-de-santo sobre elas, mais poderoso era considerado, ou seja, ao dominar a diversidade de entidades como orixás, inquices, caboclos e santos católicos agrupavam-nas em falanges ou linhas, com diversos nomes, isto é, "a linha da costa, de Umbanda, de Quimbanda, do Congo, do Mar, de Caboclo, linha Cruzada, etc. (cf. RAMOS, 1940, p. 124)."

Candomblé de Caboclo, de acordo com Silva (2005), as manifestações religiosas dos caboclos está presente na religiosidade banto, os caboclos têm o mesmo status dos orixás, daí a origem do candomblé de caboclo. Eles são os espíritos dos "donos da terra" e representam os índios que viviam antes da dominação branca e a chegada dos escravos africanos. Em muitos terreiros os caboclos são classificados em dois tipos: os "caboclos de pena" (uso do cocar) e os "boiadeiros", contato com os brancos e os hábitos deles.

Catimbó, Pajelança e Cura, conforme Silva (2005), essas religiosidades predominam pelo Norte e Nordeste do Brasil, devido a influência indígena, é uma religião mágico-curativa. O catimbó é liderado pelo mestre (chefe), pela rainha, que 
o acompanha, e pelos discípulos. Almeja-se nas sessões a invocação dos espíritos dos mestres que podem ser: indígenas, africanos ou católicos. A função dos mestres

é curar doenças, receitar remédios e exorcizar os maus espíritos do corpo das pessoas.

Na pajelança da Região Amazônica, de acordo com o autor, incorporam-se: espíritos dos mestres humanos, animais reais ou fantásticos (mãe-do-lago, cobra grande). Utiliza-se nesses ritos a jurema (bebida sagrada, feita de uma casca da árvore), na qual o pajé tinha visões e sonhos. Para concluir, de acordo com Silva (2005, p. 91): “Até o século XVIII as reuniões para beber a jurema eram vistas como reuniões de feitiçaria e muitos índios foram presos por essa prática (cf. Cascudo, 1988)".

\subsection{A UMBANDA}

A umbanda, de acordo com Silva (2005), teve origem nas décadas de 1920 e 1930 por kardecistas de classe média, no Rio de Janeiro, São Paulo e Rio Grande do Sul misturando tradições religiosas afro-brasileiras e declarando ao público em geral que essa "mistura" visava a sua aceitação legitimada e, enfim, formar uma nova religião.

A formação da umbanda, ainda, de acordo com o autor, recebeu a contribuição dos elementos formadores do universo religioso popular, principalmente das práticas bantos. A cabula, por exemplo, o chefe, denominado embanda - um possível nome de origem da religião que se formou de acordo com a ação desses líderes. Os cargos e elementos litúrgicos da cabula foram preservados na umbanda, como o de cambone, auxiliar do chefe religioso, ou enba (ou pemba), pó sagrado usado para "limpar" o local onde é realizado os rituais. "Também na macumba o 
termo umbanda designava o chefe do culto e uma de suas linhas mais fortes (cf RAMOS, 1940, p. 121, 179)" (SILVA, 2005, p. 107).

A questão das raízes africanas estão, de certa forma, dentro da Umbanda como uma força espiritual oriunda das origens africanas desta religião presentes pincipalmente no seu elo africano maior, que são os espíritos daqueles escravizados, ou seja, os preto-velhos ou pretas-velhas, atuantes na cura e orientação daqueles que os buscam nas casas de Umbanda. Como atesta Morais

\footnotetext{
A herança africana se faz presente em rituais de magia, no louvor às divindades, nos termos usados para designar os postos hierárquicos, em parte do vocabulário do culto e, em particular, numa entidade que representa os ancestrais africanos: o preto-velho (MORAIS, 2000, p. 42)
}

A umbanda surgiu em um contexto, segundo Morais, marcado pela afirmação do nacional, crescimento de uma sociedade urbana e industrial. Reunindo elementos africanos, indígenas e europeus, reproduz no campo religioso a fábula das três raças formadoras da sociedade brasileira, não reproduzindo o parentesco mítico do candomblé e formando uma organização burocratizada, tal como nas sociedades modernas. Ela não nega o Brasil, muito pelo contrário, busca-se as raízes do país. Ao vislumbrar a mistura de elementos e de realçá-lo a umbanda estava afinada com a nova elite intelectual da época, que percebia em nossa mistura não um empecilho, ao contrário uma grande oportunidade para o progresso e a superação das dificuldades.

Influenciada pela religiosidade europeia, a umbanda recebeu contribuições do catolicismo e do espiritismo, principalmente, com a questão da reencarnação, defendida por Allan Kardec, diferenciando-a das demais religiões de comunidades tradicionais de terreiro e até mesmo, do catolicismo. Para Morais (2000), Roger Bastide (1971) tem a nova opção religiosa como uma continuidade da macumba 
carioca, após sofrer influência, também, da doutrina kardecista. Ela também considera a contribuição Cândido Procópio Ferreira de Camargo (1961), pesquisador da umbanda em São Paulo, que ressalta a nova religião como um continuum do kardecismo, e o dirigente, ao buscar credibilidade e legitimação respaldava suas ações no kardecismo ou nos fundamentos africanos. Ao ressaltar a valorização da brasilidade, de acordo com Maria Isaura Pereira de Queiroz (1989), pelos intelectuais e dos grupos que valorizam a questão da diversidade de nosso patrimônio cultural na época de formação da umbanda, Morais fornece pistas de uma conexão entre intelectualidade e formadores da nova religião, afinados com a construção de uma fé brasileira e de uma mistura que dá certo e funciona com equilíbrio. A valorização da nacionalidade, mesmo que absorvendo os elementos do sincretismo, como aponta, Vagner Gonçalves da Silva (1994) confere a umbanda uma religiosidade genuinamente brasileira.

Já Renato Ortiz (1978) observou o nascimento da nova religião como um fenômeno pertencente ao cenário de transformações na sociedade brasileira que refletem no social, econômico e identitário. Segundo Ortiz, ocorre um rompimento com o simbolismo do passado e reinterpretações do tradicional, burocratizando e normatizando rituais.

O que aponta Lísias Nogueira Negrão (1996) é o reforço dessa tentativa de normatizar e decodificar ficou sob a responsabilidade das federações umbandistas, a partir do final da década de 1930. Para Morais (2000), há duas vertentes dentro da nova religião, uma que se aproximava de elementos africanos e a outra que permeia suas ações com base nas ações de elementos cristãos. No entanto, a natureza sincrética religiosa não possibilita que essas vertentes estejam estanques, a mistura é a essência da religião de umbanda. 
A umbanda, tal como o kardecismo, procura provas científicas da existência do sagrado, das entidades e da reencarnação; conforme Morais (2000). A base teórica dos argumentos está na grande quantidade de textos religiosos publicados. Neste caso, ela cita Queiroz (1989), que afirma o surgimento de uma outra hierarquia na umbanda além dos chefes de terreiro, ou seja, a dos sábios, que possuem conhecimento religioso e transmitem em livros e folhetos. A preocupação com a origem da umbanda e de dar uma credibilidade à religião, levou os teóricos umbandistas a enfatizarem o enaltecimento de uma origem mágica e ligada ao orientalismo, isto é, uma origem do sânscrito, língua sagrada pela qual descendem as demais línguas do mundo. Conforme enfatiza Morais

A sua etimologia remete ao termo "aum-bandha", que significa "o limite no limitado". O prefixo "aum" está ligado à magia e é considerado sagrado por mestres orientalistas. De acordo com essa mesma versão, defendida durante o Primeiro Congresso de Espiritismo de Umbanda, em 1941, a religião já era praticada no Brasil desde o século $\mathrm{XVI}$, sendo, depois do catolicismo, o culto mais antigo em território nacional. Os escravos africanos teriam trazido essa prática religiosa para o país, (...) (MORAIS, 2000, p. 44).

Uma outra vertente buscava verificar as origens da umbanda, tendo a África como local do surgimento da religião, o que é notabilizado

\begin{abstract}
Essa corrente era vinculada à Federação Umbandista do Rio de Janeiro, fundada por Tancredo da Silva Pinto, que teve grande influência na disseminação do culto pelo Brasil, inclusive em Minas Gerais. A versão, difundida em livros de Tancredo, considera africana a origem da palavra umbanda. O termo seria oriundo de uma tribo banta, os lunda-quiocos, situados no Sul de Angola. As fontes sagradas da origem aparecem descritas por meio de uma linguagem mitológica em que a antiguidade do homem se confunde com a antiguidade da religião. Assim, como explica Ortiz (1978), a África transforma-se em berço da humanidade e as descobertas arqueológicas tornam-se provas cientificas sobre as quais se fundamenta o argumento das origens religiosas (MORAIS, 2000, p. 45)
\end{abstract}

Além do mito de criação da religião essa versão apresenta um protagonista da nova religião, no caso, Zélio de Moraes, como atesta Morais

De acordo com essa versão, em 15 de novembro de 1908, em Niterói (RJ), o jovem Zélio de Moraes, com seus 17 anos, recebeu o Caboclo das Sete 
Encruzilhadas, durante uma sessão espírita em um centro kardecista. Essa entidade não teria tido o respaldo dos dirigentes do centro para se manifestar da forma como queria e, por isso, marcou uma sessão espírita para o dia seguinte na casa de Zélio, em São Gonçalo. No horário estipulado, o caboclo se manifestou novamente e, dessa vez, informou aos presentes que ali se criava uma nova religião que se denominaria umbanda. Estava fundado o primeiro terreiro de umbanda, a Tenda Espírita Nossa Senhora da Piedade, de onde descenderam outros sete terreiros instalados, de 1930 a 1937, na cidade do Rio de Janeiro (MORAIS, 2000, p. 45).

Zélio organiza a prática religiosa fundando a primeira federação de umbanda no ano de 1939, inspirado nos modelos das associações kardecistas, isto é, a União Espírita da Umbanda no Brasil. Essa ação federalista proporcionará um incremento deste modelo de organização entre os umbandistas, pois havia uma demanda por assistência jurídica no caso de perseguições dos agentes do Estado aos templos umbandistas.

A organização busca por legitimação da religião, através da racionalização de mitos e ritos, submetendo-os a formas racionalizadas, ou seja, uma teologia umbandista elaborada pelos líderes das federações, vislumbrando uma nacionalização da religião umbandista, organizando congressos, nos quais demonstravam o crescimento da umbanda pela sua estrutura organizacional. Essa forma de racionalizar a religiosidade e de higienizá-la é na verdade uma demonstração da aproximação dele aos valores da sociedade ocidental, principalmente, no mote inconteste da caridade, ao qual configura um viés de "alto espiritismo", combatendo os fatores que aproximam do "baixo espiritismo", realizando a "limpeza" da religião, retirando-lhe aspectos que o tornariam degradados, isto é, o sacrifício de animais, o uso de pólvora, tambores e a bebida alcoólica e do fumo. Todos esses aspectos ligados ao universo mágico e religioso dos afro-religiosos.

Essa distinção entre "alto" e "baixo" espiritismo está explicado por Negrão 
O "alto" espiritismo seria, portanto, religião protegida pelo Estado, culto semelhante aos demais e livre, inspirado nos nobres princípios da caridade, envolvendo pessoas instruídas de elevada condição social. O "baixo" espiritismo seria a prática de "sortilégios", de feitiçaria e curandeirismo enquadráveis no Código Penal, despido de moralidade e motivado por interesses escusos, envolvendo pessoas desclassificadas socialmente e ignorantes. É obvio que as práticas mágico-religiosas de origem negra se enquadravam dentro desta última categoria (NEGRÃO, 1996, p. 57).

A umbanda federalizada estava mais próxima da condição de aceitação das regras impostas para serem aceitas pela sociedade e enquadradas na lógica de uma religiosidade palatável para a elite que organizava o Estado brasileiro nos moldes da branquitude.

O conhecimento do africano era considerado atrasado e eivado de perniciosas práticas combatidas duramente pela repressão policial da época, de acordo com os códigos impostos aos brasileiros que refletiam a oficial perseguição às religiões afro-brasileiras, desde o Brasil Colônia até o período republicano, levando os praticantes o enquadramento de crimes tipificados e elencados nas legislações dos períodos colonial, monárquico e do início da República.

Devemos elaborar um não distanciamento da lógica racista e branqueadora dos atores sociais dominantes da ação do Estado, da mídia da época e de parcelas desejosas de uma modernidade forçada no Brasil, como atesta Negrão

Tínhamos, portanto, de um lado uma "religião-ciência", o alto e verdadeiro
espiritismo. De outro, a "magia-superstição" do baixo e falso espiritismo. Um
reunindo adeptos "bem de fortuna" e instruídos, outro, ilegítimo e que era ou
deveria ser, por ele reprimido. Um que carregava brancos cultivados da
mais "alta sociedade" outro dirigido por "pretos boçais" e "mulatos
pernósticos" exploradores de uma plebe multirracial sem qualificação
(NEGRÃO, 1996, p. 59).

A questão da aproximação do kardecismo era, para os umbandistas, uma forma de defenderem as suas atividades e retirar-lhes o rótulo de "falso", "suposto" ou "baixo espiritismo", ao qual, segundo Negrão (1996, p. 73), estavam agrupadas as religiões de raízes africanas, objeto de intensa repressão oficial, conservadores e 
progressistas, do início da República brasileira, defensores do capital e do trabalho, juntos contra o que consideravam retrogrado e obscurantista.

A busca de um reconhecimento legal foi um instrumento largamente utilizado pelos umbandistas, que registravam suas respectivas casas para evitar problemas com os agentes policiais destacados para a função de batidas específicas no combate aos crimes de charlatanismo ${ }^{14}$, curandeirismo ${ }^{15}$ e exercício ilegal da medicina $^{16}$.

Determinados crimes do início da República permanecem ativos no Código Penal, apesar da famosa e tão comentada liberdade religiosa, o enquadramento como crime, permanece para todos e rótulo de religiões enganadoras e promotoras de inculcar artifícios curativos são sempre aquelas que metem medo no indivíduo por lidar com forças que não são compreendidas e o que é pior, preferem demonizálas e taxar-lhes de perpetuadoras do mal, enganadoras, falsárias e mormente sujas e arcaicas.

A liberdade de crença ${ }^{17}$ é na verdade um artifício legal para mostrar aos demais países do mundo que não temos intolerância religiosa e que somos um povo que convive bem com todas as formas de manifestações religiosas e não ocorre problemas relacionados ao ódio e incômodo com a religião contrária a religião cristã, ou seja, enquanto a religiosidade é cristã, não há problemas para o praticante de determinada fé. Mas, o histórico de intolerância com as religiões de comunidades tradicionais de terreiro impele ao esforço de demonstrar que o Estado, a sociedade e na História do Brasil, desde a época Colonial aos dias atuais, verifica-se uma

\footnotetext{
14 Disponível em: <https://www.jusbrasil.com.br/topicos/10602387/art-283-do-codigo-penal-decreto-lei-284840>

${ }^{15}$ Disponível em: https://www.jusbrasil.com.br/topicos/10602358/art-284-do-codigo-penal-decreto-lei-2848-40>

${ }^{16}$ Disponível em: https://www.jusbrasil.com.br/topicos/10602464/art-282-do-codigo-penal-decreto-lei-2848-40>

${ }^{17}$ Disponível em: https://www.jusbrasil.com.br/topicos/10730845/art-5-inc-vi-da-constituicao-federal-de-88>
} 
perseguição aos afro-religiosos. Ao demonstrar o ódio do Estado Novo aos afrobrasileiros Negrão confirma a higienização das forças estatais nesse tipo específico de repressão

No campo religioso os cultos afro-brasileiros, em todo o Brasil, tiveram a primazia, talvez a exclusividade da ira do Estado Novo, ainda em nome do combate ao arcaísmo e a ignorância. O não tão moderno, mas certamente arbitrário e autoritário regime, tanto por sua aliança com a hierarquia católica, como pelos seus compromissos com a medicina institucional em que assentava sua política previdenciária, lançou-se decididamente contra as formas arcaicas e heterodoxas de práticas curativas (NEGRÃO, 1996, p. 70)

Aos umbandistas restavam neste caso aproximar-se do kardecismo e revestirse de estatutos e formas de atuação próximas do estilo federativo e organizacional dos kardecistas. Conforme a constatação de Negrão (1996, p. 67), "A partir de 1929 começamos a encontrar terreiros de Umbanda junto a cartórios de registros de títulos e documentos, se bem que desde então até o final da década de 40, travestidos de centros espíritas".

A formação da Umbanda como religião dá margem a diversas versões. No entanto, a versão apresentada por Negrão vislumbra uma busca de uma padronização

\begin{abstract}
A padronização inicial de seus ritos e seus prenúncios de institucionalização datam da década de 20 , quando kardecistas de classe média, atraídos pelos espíritos de caboclos e pretos-velhos que se incorporavam nos terreiros de macumba do Rio de Janeiro, neles adentraram e assumiram sua liderança. É possível que ele tenha ocorrido em outros Estados, sobretudo no Rio Grande do Sul. Em São Paulo houve também movimentação semelhante, embora a partir de influências cariocas. Imediatamente os adventícios passaram a moldá-la à sua imagem e semelhança: branca, cristã, ocidental. Extirpam-se dos cultos os rituais mais primitivos ou capazes de despertar os pruridos da classe média (matanças de animais, utilização ritual da pólvora e de bebidas alcoólicas), moralizamse os "guias", educando-os nos princípios da caridade cristã em sua leitura kardecista, racionalizam-se as crenças tendo-se por base a teodiceia reencarnacionista e organizam-se as primeiras federações que associam terreiros até então totalmente fragmentados (NEGRÃO, 1994, p. 113).
\end{abstract}

O Primeiro Congresso de Espiritismo de Umbanda, realizado no ano de 1941, buscava utilizar o nome espiritismo para rechaçar o rótulo de macumba, 
estigmatizado por remeter ao atraso e ao status de ignorância ao qual os líderes federativos buscavam extirpar com a organização e a nacionalização das normas e condutas a serem seguidas pelas casas dos que estavam presentes nesse Congresso. Sobre a origem dos participantes, o autor salienta a participação de congressistas dos estados das regiões Sul e Sudeste, principalmente dos Estados, São Paulo e Rio Grande do Sul. Ao constatar essa organização deste Congresso pelos Estados que apresentavam melhorias nos índices de desenvolvimento da Nação, constatamos uma direção voltada para a tendência europeizante da religião. Três intelectuais analisaram está situação, de acordo com Negrão

\begin{abstract}
As interpretações sociológicas sobre o nascimento da umbanda assentamse, como não poderia deixar de ser, em sua tríplice condição de religião nacional, surgida e consolidada no momento da expansão do sistema urbano industrial do segundo quartel do século, justamente nos centros urbanos mais importantes das regiões mais desenvolvidas do país. Roger Bastide, em sua análise que privilegia as relações raciais, considera a macumba como expressão mágica da marginalidade do negro no período pós Abolição2; já a umbanda, seria expressão ideológica da integração do mesmo à sociedade de classes nascente. Cândido Procópio Ferreira de Camargo, analisando-a também na mesma perspectiva integracionista, mas tendo o kardecismo como modelo (Camargo, 1961), interpreta-a como forma de adaptação do migrante rural ou de pequenas cidades à vida nos grandes centros urbanos. Radicalizando a interpretação, em sua perspectiva estruturalista, Renato Ortiz (1991) a percebe como uma "exigência" de uma sociedade moderna, racionalizada e moralizada (NEGRÃO, 1994, p. 114).
\end{abstract}

Negrão (1994) faz uma análise das perspectivas sociológicas e aponta as suas insuficiências, isto é, faltava adentrar nos terreiros e não reproduzir os preconceitos das teses do Primeiro Congresso (1941) e o que é pior o preconceito dos noticiários jornalísticos da época, isso tudo, no caso de Roger Bastide. Já Renato Ortiz, tem como base autores umbandistas e repete os mesmos erros do mestre. No entanto, o autor, faz uma análise positiva dos estudos de Cândido Procópio Ferreira de Camargo e sua análise da noção do "continuum mediúnico" (CAMARGO, 1961) "constituído entre o polo branco, o kardecismo, e o polo negro, a 
umbanda, com inúmeras fórmulas intermediárias (casos concretos de terreiros) entre eles" (NEGRÃO, 1994, p. 114). No entanto, Negrão, critica a ênfase de Camargo no kardecismo, não permitindo uma melhor análise da umbanda em seus estudos.

Já os estudos de Negrão parte da análise da realidade dos terreiros de umbanda do Estado de São Paulo. Não existe uma dominação das Federações sobre os terreiros neste Estado, o que acontece é uma criatividade dos pais-desanto, uma umbanda criativa e vivida no cotidiano dos terreiros pesquisados.

Sobre as federações não há uma dominante que unifique os representantes religiosos. Das mais de trinta organizações disputando a filiação de mais de 10000 terreiros, só na Capital do Estado de São Paulo.

As origens afro-brasileiras da umbanda remontam, conforme Silva (2005), ao culto às entidades africanas, aos caboclos (espíritos ameríndios), aos santos do catolicismo popular e, finalmente, às entidades adicionadas ao panteão que foram acrescentadas por influência do kardecismo. Para entender a umbanda é necessário compreender as influências do kardecismo.

\subsubsection{O Kardecismo}

Chegou ao Brasil por volta da metade do século XIX. Criado na França por Allan Kardec (pseudônimo de Léon Hippolyte Dénizart Rivail), essa doutrina filosófica e religiosa fez pouco sucesso em seu país de origem. No entanto, no Brasil obteve boa aceitação pelas classes médias e depois pela população em geral.

A doutrina do kardecismo estabelece a existência de um Deus criador, de acordo com Silva (2005), que, de certa maneira, está distante dos homens como na tradição judaico-cristã. Auxiliando a humanidade e ajudando na evolução, através da 
caridade e do amor ao próximo, temos os "guias" (os desencarnados ou espírito dos mortos).

Para Silva (2005), a reencarnação é um dos pontos centrais desse sistema religioso. As sucessivas encarnações dos espíritos permitem-lhes através do livrearbítrio, evoluir no bem ou involuir através do robustecimento do apego ao corpo material pelas vias do vício. De acordo com a "lei do carma" (de inspiração hinduísta), a cada reencarnação na Terra os espíritos colhem os frutos das boas ações ou "pagam pelas más. Essas ações definem a formação dos espíritos "de luz" ou "das trevas". A Terra é um planeta de aprendizado, expiação (pela via do sofrimento), "solidariedade e caridade (para com os que sofrem)."

Jesus Cristo, de acordo com Silva (2005), representado no evangelho de acordo com a doutrina espírita, é considerado espírito superior (a maior entidade encarnada) e exemplo de sacrifício e abdicação bases para o aprimoramento espiritual.

A mediunidade, segundo o autor, (o contato com o mundo invisível dos espíritos) é uma habilidade necessária ao homem para sua evolução espiritual. A religião proporcionaria os meios para o desenvolvimento dessa capacidade para entrar em contato com os desencarnados e seus conselhos.

No kardecismo é utilizada a aplicação dos métodos e explicações cientificas para a compreensão dos fenômenos sobrenaturais. Com isso, os fenômenos espirituais (a possessão, a vida após a morte etc.) seriam explicados pela dedução, das leis de ação e reação, causa e efeito, enfim a compreensão através de um discurso racional e religioso.

No kardecismo, os mistérios têm explicações científicas e o transe, por ser praticado por pessoas com um nível educacional maior, passou a ser aceito. 
A ciência e a razão do kardecismo proporcionaram uma valorização da escrita e da leitura. O uso de livros (psicografados pelos médiuns, com conteúdo doutrinário e uma base na moral) difundiu a religião na classe média instruída.

O nível organizacional do movimento espírita foi articulado pelas federações, que ajudou na mobilização e o desenvolvimento da religião.

Finalmente, para Silva (2005), o kardecismo, autodenomina-se uma religião cristã que legitima a possessão dos espíritos e diante dos fenômenos mágicos procura justificá-los por um discurso racional, acabou colaborando como mediador para a formação da umbanda, influenciando e sistematizando a nova religião.

\subsubsection{A codificação umbandista}

Nas sessões espíritas kardecistas, segundo Silva (2005), ocorriam manifestações de entidades ligadas as divindades africanas e indígenas, ou seja, ocorria uma absorção dos valores kardecistas pelas entidades supracitadas e atuação delas em rituais. A história do Centro Espírita Nossa Senhora da Piedade e do grupo de kardecistas liderados por Zélio de Moraes, por volta da metade da década de 1920, em Niterói. Mais tarde, ocorreu a transferência desse centro para o Rio de Janeiro, onde se localiza até hoje.

Para Diana Brown, que investigou sobre as origens da umbanda

(...) Muitos integrantes deste grupo eram, como Zélio, kardecistas insatisfeitos, que empreenderam visitas a diversos centros de "macumba" localizados nas favelas dos arredores do Rio e de Niterói. Eles passaram a preferir os espíritos e divindades africanas e indígenas presentes na "macumba", considerando-os mais competentes do que os altamente evoluídos espíritos kardecistas na cura e no tratamento de uma gama muito ampla de doenças e outros problemas. Eles achavam os rituais da "macumba" muito mais estimulantes e dramáticos do que os do kardecismo, que comparados aos primeiros Ihes pareceriam estáticos e insípidos. Em contrapartida, porém, ficavam extremamente incomodados com certos aspectos da "macumba". Consideravam repugnantes os rituais que envolviam sacrifícios de animais, a presença de espíritos diabólicos (exus), 
ao lado do próprio ambiente que muitas vezes incluía bebedeiras, comportamento grosseiro e a exploração econômica dos clientes (Brown, 1985, p. 11) (SILVA, 2005, p. 111).

De acordo com o autor, ao enfatizarem a atuação das divindades africanas e indígenas, atrasadas para os kardecistas, eles proporcionaram a criação de uma das características mais marcantes dessa religião. Os caboclos e pretos-velhos, representantes dos espíritos dos índios brasileiros e dos escravos africanos, tornaram-se protagonistas da nova religião, ajudando na formação de uma religiosidade que incluía todos as raças e classes sociais do povo brasileiro.

A umbanda, para Silva (2005), passou a ser uma forma religiosa intermediária entre as religiões populares africanas/indígenas e o kardecismo com suas concepções: carma, evolução espiritual e comunicação com os espíritos. No entanto, as formas populares africanas foram purificadas, isto é, retiraram os elementos estigmatizantes: sacrifício de animais, bebidas alcoólicas, o fumo, as danças frenéticas e a pólvora.

O discurso racional e científico do kardecismo, conforme Silva (2005), utilizando (cf. ORTIZ, 1978, p. 155) serviria, também, como legitimador do uso de elementos estigmatizados, isto é, a bebida alcoólica utilizada na ação vibração anestésica e fluídica e os seus elementos constitutivos propiciariam a limpeza de fluidos pesados dos frequentadores da sessão.

No caso da fumaça do fumo ou dos incensos, como um gás, usado na destruição dos fluidos nocivos transformando-os em fluidos favoráveis. Já a explosão da pólvora, deslocaria o ar, atingindo os espíritos perturbadores.

A umbanda teria uma origem anterior às próprias religiões africanas, no caso uma magia universal com origem do conhecimento esotérico e cabalístico dos povos egípcios e os hindus. 
Ocorreu a atribuição de uma origem na Lemúria, o continente perdido, ou ainda, a palavra umbanda da fusão de termos de origem no sânscrito ${ }^{18}$.

\subsubsection{Organização burocrática e legitimação social da umbanda}

A partir da década de 1920, do centro de umbanda de Zélio de Moraes temos a fundação da umbanda. Contudo, não é possível identificar o centro de Zélio como o primeiro e único terreiro que irradiaria a nova religião.

No final da década de 1930 e início da de 1940, o movimento umbandista passa a estabelecer uma ideologia nacional, mesmo com a perseguição do período do Estado Novo (1937-1945) às religiões afro-brasileiras, com forte repressão policial.

Ao buscar uma minimização das influências africanas, a umbanda, segundo Silva (2005), liderada por setores da classe média, buscava o embranquecimento da macumba, e, ao colocar um pouco dos valores africanos no kardecismo, adequando a moral kardequiana com a força das religiões afro e dos segmentos marginalizados da sociedade brasileira (ex-cativos, caboclos, prostitutas - os excluídos), a umbanda proporcionava a continuação da sociedade embranquecida no além, abarcando e adequando a diversidade nacional à espiritual.

A organização dos terreiros de umbanda precisava seguir um estatuto à maneira das associações civis, estabeleciam cargos, funções, horários, formas de ingresso, direitos e deveres dos associados.

\footnotetext{
18 Significado de Sânscrito - adjetivo, substantivo masculino: Nome de uma língua antiga que foi utilizada na Índia. A história do sânscrito divide-se em dois períodos. $\mathrm{O}$ antigo sânscrito é a língua em que foram escritos os Vedas, livros sagrados dos hindus. O antigo sânscrito é também chamado sânscrito védico ou simplesmente védico. A maior parte das obras em sânscrito do segundo período, o período clássico, trata de assuntos não religiosos.
} 
A hierarquia religiosa era menos complexa que no candomblé. A liderança, de acordo com Silva (2005), era do pai ou mãe-de-santo, auxiliados por pai ou mãepequena, cambonos e tocadores de atabaques e, ainda, pelo corpo de médiuns, os filhos-de-santo ou filhos de fé.

Inspiradas nas federações kardecistas, a umbanda criou as suas próprias.

No ano de 1939, Zélio e outras lideranças umbandistas "fundaram no Rio de Janeiro a primeira federação de umbanda, a União Espírita da Umbanda do Brasil”, que promoveu o "Primeiro Congresso do Espiritismo de Umbanda" (1941), no Rio de Janeiro, cujo objetivo era traçar as principais diretrizes da religião.

As federações tinham por objetivo

(...) fornecer assistência jurídica aos seus filiados contra a perseguição policial, patrocinar cerimônias religiosas coletivas, organizar eventos de divulgação da religião e, na medida do possível, impor alguma regulamentação sobre as práticas rituais e doutrinárias através da administração de cursos e da fiscalização das atividades dos terreiros filiados (SILVA, 2005, p. 115).

A umbanda, segundo Silva (2005), apresentava uma variedade de tendências doutrinárias que provocou as primeiras dissidências. No Primeiro Congresso um dos temas centrais era a busca de uma umbanda "pura", "branca", através da eliminação dos elementos africanos maléficos (quimbanda). Na década de 1950, os setores oriundos dos extratos mais baixos da população, geralmente negros e mulatos, começaram a contestar o distanciamento da umbanda das práticas africanas.

Já no Segundo Congresso de Umbanda, ocorrido no Rio de Janeiro (1961), de acordo com Silva (2005), o crescimento da religião foi nítido devido aos milhares de devotos que, lotaram o estádio do Maracanãzinho, com representantes de dez estados brasileiros e com a presença de políticos estaduais e municipais. 
Na década de 1960, a umbanda ampliou a sua organização e legitimação perante a sociedade. Ela foi beneficiada pelo clientelismo eleitoral e ajudada pela ditadura militar, como afirma Diana Brown

A umbanda passou bem nas mãos da ditadura militar instituída em 1964. Diferentemente da ditadura anterior, sob Vargas, este novo governo militar não negou aos umbandistas seus direitos políticos enquanto umbandistas nem a liberdade da prática religiosa. Ao contrário, a ditadura apoiou os ganhos políticos e sociais alcançados nos 15 anos anteriores e auxiliou a sua institucionalização. Foi sob a ditadura militar que o registro dos centros de umbanda passou da jurisdição policial para a civil [em cartório], que a umbanda foi reconhecida como religião no censo oficial, e que muitos dos seus feriados religiosos foram incorporados aos calendários públicos locais e nacionais, de caráter oficial (BROWN, 1985, p.37).

No Terceiro Congresso de Umbanda (1973), ocorreu a afirmação definitiva da religião como uma das que mais crescem e com uma forte atuação na assistência aos necessitados. A caridade e a ajuda espiritual aconteciam nos centros ou instituições como escolas, creches, ambulatórios etc.

A religião recebeu mais adeptos devido a publicidade em programas de rádio, jornais e publicações próprias, os incentivos para divulgação contaram com o apoio de políticos umbandistas e dos simpatizantes.

A legitimação social, permissão legal e apoio institucional de órgãos governamentais resultaram na possibilidade da realização de festas em espaços públicos.

O dia 31 de dezembro, no Rio de Janeiro, no qual muitos umbandistas vão às praias para levar presentes para lemanjá, foi proclamado, em 1967, como “Dia dos Umbandistas" (SILVA, 2005, p. 117).

No Estado de São Paulo, devido à popularidade da festa de lemanjá, no dia 8 de dezembro (dia de Nossa Senhora da Conceição, com quem é sincretizada), a Prefeitura de Praia Grande construiu uma estátua em homenagem a lemanjá com 
cinco metros de altura. A festa de lemanjá faz parte do calendário turístico da cidade atraindo umbandistas e simpatizantes.

Outras festas da umbanda, como o 13 de maio, data da Abolição da Escravatura que passou a ser feita em homenagem aos pretos velhos, ou a do dia 23 de abril, homenagem a São Jorge (orixá Ogum), muito festejado por todo o Brasil.

2.6.4. As entidades "brasileiras" da umbanda

$\mathrm{Na}$ umbanda, as entidades apresentam diferentes significados de suas finalidades africanas no candomblé, como também diferenças com relação ao kardecismo.

Para o candomblé, as divindades africanas são deuses que tutelam um clã, linhagem ou cidade, ou, ainda, deuses pessoais.

No kardecismo, as entidades recebidas no corpo daqueles que estão aptos para receber os espíritos dos mortos, isto é, os médiuns. Tanto os espíritos dos mortos quanto aos médiuns cumprem um papel fundamental no espiritismo que é a caridade e a ajuda aos vivos e aos mortos, ou seja, a caridade como princípio universal.

De acordo com Silva (2005, p. 120), "na umbanda, as entidades situam-se a meio caminho entre a concepção dos deuses africanos do candomblé e os espíritos dos mortos dos kardecistas."

As entidades no candomblé foram agrupadas buscando preservar as origens africanas. Já na umbanda, as entidades foram organizadas de acordo com a teoria das linhas, segundo Silva

(...) existem sete linhas dirigidas por orixás principais. Cada linha é composta por sete falanges ou legiões. O número sete é devido ao seu 
valor cabalístico. Algumas dessas linhas são: Linha de Oxalá, Linha de lemanjá, Linha de Xangô, Linha de Ogum, Linha de Oxóssi, linha das Crianças e Linha dos Pretos Velhos. Não existe, entretanto, um consenso entre os vários terreiros e codificadores da umbanda a respeito da composição dessas linhas e falanges. Em muitos casos, por exemplo, juntam-se às linhas dirigidas pelos orixás a Linha do Oriente (da qual fazem parte as ciganas), a Linha das Almas etc. (SILVA, 2005, p. 121).

Ainda de acordo com Silva, para formar uma religião nacional colocaram os elementos fundantes da sociedade brasileira, os caboclos (indígenas) e pretos velhos

\begin{abstract}
Abaixo dos orixás encontram-se os espíritos um pouco menos evoluídos, como os caboclos e os pretos velhos. Pode-se dizer que essas entidades, embora tenham nomes próprios (caboclos Sete Flechas, Rompe Mato, preto velho Pai João, vovó Maria Conga etc.) e sejam espíritos de indivíduos como na concepção kardecista -, remetem muito mais aos segmentos formadores da sociedade brasileira. Os caboclos representam o indígena enaltecido na literatura romântica e popularizado na pajelança, no catimbó e no candomblé de caboclo. Quando incorporados, apresentam-se como "católicos", e frequentemente abrem seus trabalhos espirituais com orações do tipo pai-nosso e ave-maria (SILVA, 2005, p. 121).
\end{abstract}

Já de acordo com Silva, os pretos velhos, ou seja, o africano que foi submetido ao regime de trabalho forçado vigente na formação da nossa sociedade, tem uma importante missão na umbanda

\begin{abstract}
O preto-velho, quando incorporado nos médiuns, apresenta-se como o espírito de um negro escravo muito idoso que, por isso, anda todo curvado, com muita dificuldade, o que o faz permanecer a maior parte do tempo sentado num banquinho fumando pacientemente seu cachimbo. Esse estereótipo representa a idealização do escravo brasileiro que, mesmo tendo sido submetido aos maus-tratos da escravidão, foi capaz de voltar à Terra para ajudar a todos, inclusive aos brancos, dando exemplo de humildade e resignação ao destino que Ihe foi imposto em vida (SILVA, 2005, p. 121/123).
\end{abstract}

Após as Linhas e os espíritos intermediário, temos os espíritos das trevas, de acordo com Silva (2005), entidades que os médiuns incorporam para serem, de acordo com o ideal de caridade e ajuda da umbanda, doutrinados. São os exus e pombagiras. Os exus na umbanda carregam o estereótipo que o catolicismo atribuiu ao orixá Exu associado ao diabo, à morte e a sexualidade desenfreada. A 
pombagira, versão feminina do Exu, geralmente, está associada ao estereótipo da prostituta, da vulgaridade da mulher da rua com todos os seus trejeitos.

As entidades das trevas, segundo Silva (2005), são solicitadas para a resolução de problemas de saúde, desemprego e outras aflições. As pombagiras auxiliam nos problemas amorosos, afetivos ou sexuais, por estarem relacionadas as questões do coração e do desejo.

Ainda de acordo com o autor, as entidades das trevas não são aceitas nos terreiros de umbanda ligados as bases do kardecismo. Contudo, nos terreiros que utilizam de práticas africanas mais populares, as giras dessas entidades realizadas pelos menos uma vez ao mês, geralmente às sextas-feiras depois da meia-noite, são conhecidas no meio umbandista como giras de quimbanda.

Existem outras entidades, conforme Silva (2005), que podem se situar no mesmo plano ou evoluídas espiritualmente, com relação aos exus e pombagiras. Nesta situação temos: zé-pelintra, baianos, ciganas, marinheiros etc. Representantes dos segmentos marginalizados durante a sua existência na terra, ao ingressarem no plano superior, encontram-se evoluídos e ajudam aqueles que, porventura, sofrem dos mesmos estigmas aos quais sofrem os vivos, ou ainda, essas entidades sofreram na vida real.

A umbanda devida a todas essas características elencadas se desenvolveu para uma religião que carrega uma brasilidade na sua prática religiosa.

\section{O CONCEITO DE TOLERÂNCIA}

A tolerância é uma das molas mestras da concretização de políticas concernentes aos Direitos Humanos. Ao nos depararmos com o termo, verificamos que não é algo muito aceito na sociedade brasileira, dada a dificuldade de 
adentrarmos em um processo de Modernidade ou de uma interpretação equivocada da mesma, pois, como elenca Estramiana e Severiano, a tolerância foi criada a partir da Modernidade, portanto, é um conceito que, quando verificado na prática, resulta em uma concessão do poder constituído e dos grupos dominantes, religiosos ou laicos, majoritários ou não (ESTRAMIANA; SEVERIANO, 2003, p. 17).

A vida em um ambiente democrático requer tolerância e liberdade como valores básicos, pois sem estes critérios fica difícil vislumbrarmos uma harmonia nas relações e, consequentemente, surgirão problemas, restrições e atos de intolerância, principalmente a religiosa, que é a questão motivadora deste trabalho devido aos constantes ataques intolerantes aos praticantes das religiões de matriz africana no Brasil.

A tolerância deverá ser analisada para compreendermos a sua utilização como dimensão crítica na luta contra a intolerância e o fanatismo religioso. Tolerar é algo anterior aos pensadores da ilustração, pois leva a conceitos usados por Berger (2017), como o pluralismo, que aparenta ter sido algo atual, mas apareceu em diversos contextos históricos elencados por este teórico do pluralismo que o conceitua desta forma: "o pluralismo é uma situação social na qual pessoas de diferentes etnias, cosmovisões e moralidades vivem juntas pacificamente e interagem amigavelmente" (BERGER, 2017, p. 20). Dessa forma, antes de apresentarmos a tolerância e suas relações com a ilustração, devemos demonstrar o quanto os valores do pluralismo, de acordo com Berger, existiu em diversos contextos históricos, primeiro na Antiguidade

O pluralismo, tal como eu defini, existiu em diferentes formas em vários momentos da história. Ele constitui uma longa tradição nas culturas da Ásia Oriental, especialmente na China e no Japão. A Índia pré-islâmica exemplificou o pluralismo de uma maneira um pouco diferente. Durante vários séculos, os países ao longo da Rota da Seda demonstraram um 
pluralismo religioso exuberante, com cristãos, maniqueus, zoroastrianos, hindus, budistas e intelectuais confucianos interagindo uns com os outros, frequentemente no contexto dos Estados helenistas deixados para trás como um legado das conquistas orientais de Alexandre o Grande." (...)

O helenismo, que floresceu nos centros urbanos do Império Romano tardio, era uma forma muito característica de pluralismo e foi muito importante para o curso da civilização europeia (BERGER, 2017, p. 24).

No islã e na Idade Média, Berger (2017) cita casos de pluralismo e de certa maneira tolerância com aqueles que professavam uma fé diferente daqueles que controlavam o poder nos contextos históricos referidos

Houve períodos (alguns curtos, outros mais longos) na história do islã em que os governantes permitiam e mesmo incentivavam o pluralismo religioso e cultural, como na Espanha muçulmana, na Índia mongol e no Império Otomano; no primeiro caso, um termo especial, convivência, foi cunhado para indicar a coexistência amigável entre muçulmanos, cristãos e judeus. A Idade Média cristão na Europa, um período histórico não famoso pela tolerância, também apresentou episódios pluralistas. Um exemplo disto é o governo dos Hohenstaufen na Sicília; outro é Langue d'Oc naquilo que é agora o sul da França, que foi governado pelo Conde de Toulouse, que era ele próprio católico, mas tolerou e mesmo protegeu os albigenses, até que uma cruzada particularmente feroz vinda do norte exterminou a heresia albigense e neste processo destruiu a cultura pluralista (BERGER, 2017, p. 25).

Conceito importante para a compreensão da tolerância é a questão da modernidade, que Berger aborda com propriedade e indica um caminho ligado a organização das cidades, dos governos e do desenvolvimento de determinadas tecnologias necessárias para a diminuição de distâncias e de certa maneira, a facilitação da apropriação do conhecimento, como podemos notar

A modernidade pode ser definida muito sucintamente como um produto das mudanças provocadas pela ciência e pela tecnologia criadas nos últimos séculos - um processo cada vez mais acelerado, com consequências que afetam um número cada vez maior de áreas da vida humana. De certa forma, a modernização significa uma espécie de urbanização em expansão, de modo que cada vez mais pessoas em todo o mundo vêm respirar o "ar da cidade", ainda que muitas delas ainda vivam em lugares que não - ou ainda não - são cidades. Assim, o pluralismo se torna globalizado. De certa forma, todo o planeta se torna uma enorme cidade (BERGER, 2017, p. 24).

A tolerância nem sempre foi aceita e adotada pelos homens, constatamos a sua acepção como corolário de uma vivência pacífica somente após diversos conflitos religiosos e com decisões traumáticas e desfavoráveis ao ambiente de 
diversidade de escolhas religiosas que foi surgindo com o Século das Luzes e a virtude da tolerância como um fator para impedir os desmandos e as bases ideológicas do Antigo Regime, ou seja, o absolutismo monárquico e as diversas tentativas de imposição da vontade do rei sobre os súditos dos seus respectivos reinos (ESTRAMIANA; SEVERIANO, 2003, p. 17).

Nos estudos sobre a tolerância como valor ilustrado, Estramiana e Severiano destacam os exemplos louváveis dos autores da ilustração, como o francês Voltaire em seu Ensaio sobre a Tolerância (1763) e o inglês John Locke, em à sua Carta sobre a Tolerância (1689). Ambos os autores abordam textos que desqualificam os usos e abusos da religião como exercício de poder para as autoridades que a utilizavam como ferramenta para a manutenção de suas respectivas autoridades e o que é pior, o uso da Lei para a imposição da religião nos Estados europeus e as circunstâncias agravantes de abusos dessas autoridades, tanto políticas quanto religiosas, oprimindo o povo, as minorias religiosas e criando um ambiente de violência religiosa autorizada pelos homens e implementada pelos governantes e autoridades elencadas (BERGER, 2017, p. 17).

Para verificar a tolerância como conceito, utilizaremos como base de referência os conceitos de John Locke sobre tolerância em sua obra Carta acerca da tolerância, que foi elaborada durante o seu exílio na Holanda, que durou cinco anos e meio. Quando decidiu sair da Inglaterra em 1683, seus receios estavam na prisão e morte, devido à sua visceral ligação política como conde de Shaftesbury, ligado aos whigs, partido ligado a Câmara dos Comuns que defendia um Parlamento forte. Os realistas ou defensores do absolutismo real, representado pelos tories, tinham motivos para perseguir Locke, principalmente após as suas críticas ao absolutismo monárquico expostas em suas obras, Dois tratados sobre o governo (LOCKE, 1983, 
p. 7). Locke retornou após a consolidação da Revolução Gloriosa na Inglaterra (1688). A carta sobre a tolerância foi dedicada a Philip van Limborch, que a publicou no ano de 1689 (LOCKE, 1983, p. 8/9).

O contexto histórico vivido por Locke sugere a utilização de sua Carta, devido aos constantes atritos entre as autoridades civis e as autoridades religiosas. A interferência dos políticos nas questões religiosas e vice-versa transformaram o Reino Unido do século XVII em um local hostil e conflituoso.

Para informar sobre o que Locke desejava com a Carta, devemos refletir acerca de suas crenças ao elaborar sua obra, isto é, acreditar na solução do problema dos conflitos de sua época era simples, desde que ocorresse a separação dos assuntos do Estado daqueles referentes à Igreja. Ou seja, enquanto os interesses de um se misturavam ao outro não haveria um passo adiante para a um ambiente de tolerância. Locke acreditava em uma separação radical entre a política e a religião, o que não era o objetivo dos reis ingleses que ocupavam o trono no momento de elaboração de sua obra e antes da confecção dela. O absolutismo pretendido pelos reis ingleses chocava com os interesses do Parlamento, que desejava a limitação do poder real e a sua submissão aos interesses dos representantes do povo que estavam colocados na casa parlamentar.

Locke tinha concepções a respeito do poder estatal bem diferentes dos interesses reais, isto é, o Estado nascia da necessidade de o homem obedecer a Lei Natural, ou seja, assegurar a vida, a liberdade e os bens. Neste caso, o objetivo seria conservação e a promoção do patrimônio material, bem como da ação do magistrado, que utiliza da força pública na coação - tudo garantido pelo conjunto de leis validada por uma autoridade que permitisse um ambiente de paz e a integridade de cada um. 
Já a Igreja, segundo Locke (1983), é uma associação livre e não tem obrigações com a Lei Natural, ou seja, a função de uma Igreja é afirmar uma fé de maneira pública e cultuar a Deus por meio de um acordo comum entre os fiéis. A defesa da fé, ainda de acordo com Locke, é o direito de discutir de argumentar e de exortar. A única forma de sanção de uma Igreja é para com aqueles que, fazendo parte de sua comunidade de fiéis passa a desobedecer ou mesmo instrumentalizar divisões e afrontas às autoridades doutrinárias e aos processos de liturgia ou catecismo.

Segundo Locke (1983), Estado e Igreja são entes distintos e que não deveriam ter laços. A tolerância deveria ser a essência de qualquer igreja, pois ela não possui poder de coação. Essa coação por parte da Igreja contrariava Locke que acreditava na verdadeira potência do aspecto religioso, a fé. Conversão não deveria ser pela imposição de força e sim pela paz e pelo amor anunciados pelos Evangelhos, nos quais o fiel encontraria a verdade que se impõe por meio espirituais e não por meios diversos (LOCKE, 1983).

A importância da Carta sobre a tolerância é oriunda da maneira como ela enfoca a separação dos assuntos seculares dos religiosos e ajuda na instauração do Estado secular e no direito à liberdade religiosa presente nas cartas constitucionais americana (1787) e francesa (1791) (LOCKE, 1983, p. 7/8)

O que Locke desejava em suas cartas sobre a tolerância era a defesa da liberdade de consciência religiosa, ou seja, o Estado deveria cuidar das necessidades básicas dos cidadãos e não defender uma religião e ficar refém das vontades dela (LOCKE, 1983).

Segundo Locke, a verdadeira religião não está no domínio e na força, mas deve regular a vida dos homens segundo a virtude e a piedade. A religião cristã, 
ainda de acordo com Locke, deve ser colocada dentro do próprio coração, vivida através dos exemplos dos apóstolos expostos no Evangelho, ou seja, ninguém poderá ser cristão sem o auxílio da fé atuante, não pela força e sim pelo amor. Adverte àqueles que perseguem aos demais homens em nome da religião, já que sua ação é baseada na bondade e amizade aos perseguidos. Aos que prestam esse desserviço de imposição da religião àqueles de fé diversas e aos que são julgados indignos de viverem como cristãos, as atitudes vis de perseguição não os elevará à condição de mártires (LOCKE, 1983, p. 3).

Ao preocupar-se com o reino de Deus, de acordo com Locke, o homem pensa em ter o dever de lutar para o seu engrandecimento, entretanto, ele quer perseguir os opositores estabelecido nas seitas e esquece de lutar contra os seus próprios vícios; não adianta ser implacável para com os que discordam de sua opinião e ter tolerância com os pecados que não são condizentes com as atitudes cristãs (LOCKE, 1983, p. 4).

Cada um, segundo Locke, entra em uma religião por acreditar que ela seja a portadora de uma salvação e uma religiosidade aceitável por Deus. Essa é uma forma de união voluntária do indivíduo à dominação ao qual escolheu. Não existe transmissão de fé por hereditariedade, a qualquer cidadão é permitido a livre escolha religiosa, conforme a defesa de Locke (LOCKE, 1983, p. 6). No entanto, esse mesmo autor, defende a liberdade de entrada e a de saída de uma religião, a união de um determinado fiel a uma determinada denominação não configurará um laço indissolúvel. E, mais uma vez, ele sustenta a ideia de uma união voluntária para formar uma sociedade religiosa, nunca de maneira forçada, arregimentação de fiéis por violência ou grave ameaça não deve ser feita em nenhuma hipótese (LOCKE, 1983, p. 7). 
Devemos destacar a defesa inconteste de Locke à tolerância mútua não só entre os indivíduos de diferentes denominações como também aos diferentes credos religiosos, relacionando-se através da harmonia e respeito, mesmo que determinada denominação tenha o apoio do governo ou o governante apoie, ou seja, ligado a determinada religião que queira se valer desse seu partidarismo religioso para impor essa determinada fé, prejudicando as minorias religiosas. Isso só levará a conflitos e desordens sociais, a religião não deve ser imposta pelas armas. A autoridade eclesiástica deve estar concentrada na religião, ou seja, nos limites da Igreja, não assumindo e controlando o mundo civil, pois a religião é algo diferenciado da comunidade e de sua organização, como afirma Locke, o céu e a terra não devem ser misturados (LOCKE, 1983, p. 10).

Locke enfatiza a questão do pretexto do governante ao querer impor uma religião visando a salvação das almas de seus governados, isto é, ninguém deve ser forçado a se salvar, ou seja, tudo deve ser feito para que cada um tenha a liberdade de escolher o que é melhor para si. A liberdade de reunião pública para testemunhar aos demais membros da sociedade que são cultuadores de Deus devem ser incentivados e não embaraçados pelo legislador (LOCKE, 1983, p. 14).

Locke admitiu que a religião poderia ser usada como justificativa da dominação e espoliação de outros povos, como foi usada no caso da colonização inglesa em terras americanas e na expulsão dos nativos de suas terras por não aceitarem viver como os cristãos e adotarem costumes idólatras (LOCKE, 1983, p.18). Sobre essa questão, ele faz uma distinção clara entre a comunidade dos judeus que não admitiam a idolatria, pois era uma teocracia, ou seja, as leis estabelecidas por Deus eram leis civis, o que não é de forma alguma estabelecida 
no evangelho dos cristãos, isto é, aos cristãos não deve ser feito leis de supremacia religiosa e de aceitação dos princípios cristãos pela força (LOCKE, 1983, p. 19).

Locke assegura que aos "que negam a existência de Deus não devem ser de modo algum tolerados". Ao acreditar que ao ateu não se deve aceitar a tolerância, ele considera que o ateísta destrói a religião com o seu negacionismo, retirando a base do aspecto religioso que para o autor é a crença no Deus único (LOCKE, 1983, p. 23/24).

Uma lei da tolerância evitaria, segundo Locke (1983), sedições e liberdade reprimida que costumam ser as bases para os casos de intolerância e a busca de imposição religiosa que leva fatalmente aos conflitos religiosos. Essa lei deveria obrigar a ensinar o estabelecimento para todas as igrejas de uma liberdade como princípio de respeito de uma denominação para com as outras, mesmo quando não concordam entre si nas questões sobre fé. Assim, ninguém deveria ser obrigado a seguir uma religião ou doutrina religiosa, mesmo que seja estabelecida por lei ou por ameaça. Isso evitaria os conflitos e estabeleceria um regime de paz e entendimento dos cidadãos, mesmo que eles não concordem com esse princípio de trégua na questão religiosa (LOCKE, 1983, p. 24).

Com relação às revoltas ou conspirações tramadas, mesmo que num ambiente religioso, Locke foi enfático em alertar contra este tipo de discurso dentro de uma denominação religiosa ou em uma praça pública. O governante tem o direito de reprimir ambas devido às intenções sediciosas as quais inspiram a perturbação da paz pública. O autor ainda completa que aqueles que são pacíficos e de condutas corretas devem ter tratamento equânime aos demais cidadãos independentes se são pagãos, maometanos ou judeus. (LOCKE, 1983, p. 26). Locke vai no cerne da questão da intolerância ao considerar que 
Não é a diversidade de opiniões (o que não pode ser evitado), mas a recusa de tolerância para com os que têm opinião diversa, o que se poderia admitir que deu origem à maioria das disputas e guerras que se tem manifestado no mundo cristão por causa da religião (LOCKE, 1983, p. 27).

A sua visão acerca dos conflitos religiosos parece uma previsão do que ocorre na atualidade na sociedade brasileira, foco de nosso interesse sobre as razões que levam ou levaram aos indignos atos de intolerância religiosa e à falta de um diálogo e respeito aos demais pelas opiniões diversas ao qual possuem

Tem sido este o curso dos eventos comprovados com abundância pela História, sendo, portanto, razoável supor que o mesmo ocorrerá no futuro, se o princípio de perseguição religiosa prevalecer, tanto por parte do magistrado como do povo e se os que devem servir de escudeiros da paz e da concórdia incitarem os homens às armas ao som da trombeta de guerra, soprada com toda força de seus pulmões. E de admirar que os magistrados tolerem esses incendiários e perturbadores da paz pública, se não transparecesse terem sido convidados para participar dos espólios, usando frequentemente da própria cobiça e orgulho como meio de aumentar o próprio poder (LOCKE, 1983, p. 27).

Locke aponta para um acordo entre Igreja e Estado como a fonte desses conflitos e aponta como solução para esse problema que cada um cuide de sua respectiva função: "- um cuidando apenas do bem-estar material da comunidade, outro da salvação das almas - possivelmente não haveria entre eles nenhuma discórdia" (LOCKE, 1983, p. 27).

Na obra de Voltaire, Ensaio sobre a Tolerância (1763), o autor contestou o julgamento sobre o caso Jean Calas, um jansenista, acusado de um crime que não foi cometido por um tribunal manipulado pelo fanatismo e pela volição de um justiçamento para vivificar o bicentenário do Massacre de São Bartolomeu, onde milhares de huguenotes, calvinistas franceses, foram executados (ESTRAMIANA; SEVERIANO, 2003, p. 18). Voltaire condena o fanatismo na Europa relatando essas disputas e suas motivações 
Sabe-se bem demais quais foram os custos desde que os cristãos começaram a disputar por dogmas: correu sangue, seja nos cadafalsos, seja nas batalhas desde o século IV até os dias de hoje. Vamos nos limitar às guerras e aos horrores que as querelas da Reforma excitaram e veremos quais foram as fontes disso na França. Talvez um quadro detalhado e fiel de tantas calamidades possa abrir os olhos de algumas pessoas pouco instruídas e tocar os corações bem-orientados (ESTRAMIANA; SEVERIANO, 2003, p. 24).

Ainda relatando sobre os excessos cometidos em nome da religião na Europa e que proporcionaram aberrações fanáticas, vejamos

(...) A filosofia, unicamente a filosofia, irmã da religião, desarmou as mãos que a superstição havia ensanguentado por tanto tempo; e o espírito humano, ao despertar de sua embriaguez, assombrou ante os excessos 0 que o havia lançado o fanatismo (ESTRAMIANA; SEVERIANO, 2003, p. 18).

A razão é um excelente remédio contra a insensatez das disputas religiosas, como afirma Voltaire, "a razão é doce, é humana, inspira a indulgência, abafa a discórdia, fortalece a virtude, torna agradável a obediência às leis, mais ainda que a força pode obrigar a cumpri-las" (ESTRAMIANA; SEVERIANO, 2003, p. 45).

O direito de ser intolerante poderia ser considerado como algo natural e dentro do reconhecimento humano de querer para o próximo o melhor para a sua salvação, de acordo com a vontade do intolerante. No entanto, Voltaire considera que

O direito da intolerância é, portanto, absurdo e bárbaro; é o direito dos tigres, sendo bem mais horrível também, porque os tigres dilaceram suas presas para comer, enquanto nós nos exterminamos por causa de alguns parágrafos.

A intolerância é uma alternativa que desonra o cristão como assegura Voltaire: "Quanto mais a religião cristã é divina, tanto menos pertence ao homem dirigi-la: se foi Deus que a fez, Deus a sustentará sem a nossa ajuda." (ESTRAMIANA; SEVERIANO, 2003, p. 84). E, ainda, sobre as atrocidades praticadas e suas consequências, não permitem uma salvação ou mesmo um livramento dos delitos praticados aos que não comungam da mesma fé do fanático 
Se a perseguição contra aqueles que discutem conosco fosse uma ação santa, seria preciso admitir que aquele que tivesse causado a morte do maior número de heréticos seria o maior santo do paraíso." (Ibid., 88 e 89) A intolerância e o povo escolhido por Deus, segundo Voltaire, "A Escritura nos ensina, portanto, que Deus não só tolerava todos os outros povos, mas que também lhes demonstrava cuidados paternais. $E$ nós ousamos ser intolerantes! (ESTRAMIANA; SEVERIANO, 2003, p. 102).

Talvez os perseguidores utilizassem do Novo Testamento e na desculpa para

seus excessos na expulsão dos comerciantes do templo e a expulsão dos demônios realizadas por Jesus Cristo, ou seja, se Cristo utilizou da ação contra os inimigos da Boa Nova, os fanáticos sentiram nessa passagem um álibi para suas ações persecutórias e aniquiladoras dos que carregam ou pertencem as hostes das trevas. Vejamos o que Voltaire trata sobre essas questões

O espírito perseguidor, que abusa de tudo, busca ainda sua justificação na expulsão dos vendilhões do templo e na legião de demônios que foram expulsos do corpo de um possuído e enviados para corpos de dois mil animais imundos. Mas será que não se vê que esses dois exemplos não são outra coisa senão uma justiça que Deus se digna a realizar por si mesmo em uma contravenção da lei? Era uma falta de respeito para com a casa do Senhor transformar o seu recinto em uma loja de comerciantes. Não importa que o sinédrio e os sacerdotes permitissem esse negócio para a comodidade dos sacrifícios: o Deus a quem se sacrificava poderia, sem dúvida, mesmo que disfarçado em figura humana, impedir tal profanação, ele poderia até mesmo punir os que introduziam rebanhos inteiros de animais proibidos por uma lei que ele se dignava a observar. Esses exemplos não têm o menor relacionamento com perseguições motivadas por dogmas. É necessário que o espírito da intolerância seja apoiado por razões muito más, uma vez que busca em toda parte pretextos mais vãos (ESTRAMIANA; SEVERIANO, 2003, p. 113/114).

Voltaire utilizou diversas frases para demonstrar como a intolerância religiosa deveria ser esquecida e a tolerância para com aqueles que não professam a mesma fé, praticada e observada por aqueles que se proclamam cristãos, principalmente, onde estaria o exemplo de Cristo em atos de intolerância religiosa? Vejamos algumas frases importantes

É uma impiedade tirar a liberdade dos homens em matéria de religião, impedir que eles tenham a sua própria escolha de divindade; nenhum homem, nenhum deus gostaria de ser servido à força. (Apologética, Capítulo XXIV). 
Uma religião forçada não é religião: é necessário persuadir e não obrigar. Não se ordena absolutamente a adoção de uma religião. (Lactâncio, Livro III).

É uma heresia execrável querer atrair pela força, por espancamentos, por aprisionamentos aqueles que não se pôde convencer pela razão. (Santo Atanásio, Livro Primeiro). Nada é mais contrário à religião do que a violência. (São Justino Mártir, Livro V). Aconselhai e não forçai. (Carta de São Bernardo). Nós não pretendemos de maneira alguma destruir os erros mediante a violência. (Mensagem dos clérigos da França a Luís XIII). Nós sempre desaprovamos os métodos de rigor. (Assembleia dos Clérigos, 11 de agosto de 1560). Sabemos que se persuade à fé, mas não se obriga a ela. (Fléchier, bispo de Nimês, Carta Dezenove). Não se deve sequer usar de termos insultuosos. (Bispo Du Bellay, em uma Instrução Pastoral de 1688). Concedei a todos a tolerância civil. (Fénelon, Arcebispo de Cambrai, comunicação ao duque de Borgonha). A fé não se inspira a golpes de espada. (Cerisiers, Sobre os reinados de Henrique IV e de Luís XIII) (ESTRAMIANA; SEVERIANO, 2003, p. 119/121).

Em uma de suas observações, Voltaire considera que o fanatismo é uma das molas mestras para os atos de intolerância. Os legisladores não podem ser omissos diante das repetidas e anunciadas demonstrações de fanáticos religiosos no Brasil, se pretendemos viver em um país onde a liberdade religiosa seja devidamente respeitada, não se deve permitir espaços para fanáticos que não só discursam livremente, estimulam o ódio e perseguições aos que não comungam de sua respectiva fé proporcionando uma beligerância no ambiente de nossa frágil democracia brasileira. Senão vejamos

Para que um governo não tenha o direito de punir os erros dos homens, é necessário que esses erros não sejam crimes; os erros são crimes quando perturbam a sociedade; eles perturbam a sociedade desde que inspirem fanatismos: é preciso, portanto, que os homens comecem por deixar de ser fanáticos a fim de merecer a tolerância (ESTRAMIANA; SEVERIANO, 2003, p. 136).

Para Estramiana e Severiano (2003), Locke tinha uma "concepção liberal de tolerância, vinculado à noção de indivíduo". Já para Voltaire, "a tolerância respaldase sobre o princípio básico da igualdade entre os homens". Ainda, "Voltaire ao partir da tradição racionalista da ilustração francesa, transcende as concepções empiristas de Locke, ao fazer do caso de Calas um manifesto da tolerância como direito e valor universal" (ESTRAMIANA; SEVERIANO, 2003, p. 18). 
Voltaire com sua obra faz da defesa de um injustiçado uma ferramenta contra os abusos dos intolerantes que se valem das normas autoritárias para justificar o julgamento com base na intolerância religiosa. Para isso, ele revelou três dimensões da tolerância, a saber: "luta contra a intolerância, universalidade e reciprocidade." Vejamos o que considera Estramiana e Severiano neste contexto

\begin{abstract}
Obviamente, a tolerância supõe a erradicação da intolerância: a tolerância como valor somente se consegue através da supressão do fanatismo, da superstição, do dogmatismo, do abuso do poder, da imposição pela força das ideias. Em segundo lugar, supõe a existência de um nós distinto do nós tribal, grupal, nacional; supõe conceber o outro não enquanto membro do 'meu' grupo religioso, étnico ou nacional, mas em perceber-lhe como um outro igual a mim mesmo, reconhecendo-lhe como pessoa e não como membro intercambiável de um grupo social. Finalmente, Voltaire estabelece uma condição de tolerância, qual seja, a reciprocidade. A tolerância supõe por parte do outro não apenas a aceitação da defesa das minhas ideias, mas também a renúncia a impor-las mediante o uso de quaisquer formas de poder (ESTRAMIANA; SEVERIANO, 2003, p. 19).
\end{abstract}

Kant, alertava sobre o uso da tolerância como uma concessão arrogante daquele que controla o poder. A primazia da razão do ideal kantiano leva a questão da tolerância como um dever ético de promoção da igualdade entre os povos para a construção da democracia e das liberdades civis (ESTRAMIANA; SEVERIANO, 2003, p. 19).

Os pensadores da Escola de Frankfurt condenaram os pressupostos das sociedades industrializadas, isto é, a dominação e a conquista do poder, tendo por base o requisito da eficiência e o uso de técnicas que resultaram no fracasso do lado democrático e tolerante e na ascensão de regimes totalitários, levando o mundo aos horrores de duas Guerras Mundiais. O resultado dessas constatações levou-os à condenação da razão iluminista como triunfo de uma ditadura tecnicista.

A razão não seria mais a solução para os problemas da humanidade? Onde a ilustração estava equivocada? De acordo com a obra de Adorno e Horkheimer, Dialética do Esclarecimento, escrita em 1944, temos 
No sentido mais amplo do progresso do pensamento, o esclarecimento tem perseguido sempre o objetivo de livrar os homens do medo e de investi-los na posição de senhores. Mas a terra totalmente esclarecida resplandece sob o signo de uma calamidade triunfal. O programa do esclarecimento era o desencantamento do mundo. Sua meta era dissolver os mitos e substituir a imaginação pelo saber (...), contudo, a credulidade, a aversão à dúvida, a temeridade no responder, o vangloriar-se com o saber, a timidez no contradizer, o agir por interesse, a preguiça nas investigações pessoais, o fetichismo verbal, (...) impediram um casamento feliz do entendimento humano com a natureza das coisas (Adorno e Horkheimer, 1944, p. 19).

Nesta situação, ao se colocarem como senhores, os homens focaram em uma razão utilitarista capaz de revirar os rincões do mundo no intuito de explorá-lo e dominá-lo e não só a utilização das coisas, bem como a coerção do humano presunçoso de seu saber sobre uma maioria temerosa e titubeante.

O desenvolvimento de uma "razão instrumental" fornece o desenvolvimento da intolerância e o rompimento com os princípios éticos necessários para o desenvolvimento de uma "razão crítica" no que se refere as bases do lluminismo. A ação aética, o descalabro da busca dos contatos e dos relacionamentos, vislumbrando os lucros e adição de medidas para ideologizar a razão instrumental, transformam-nos em meros números e busca-se, com essa nova forma de agir, uma formação de elementos capazes de agir por agir e propícios a colocarem a intolerância como regra de convívio social.

A pluralidade de elementos ligados à personalidade etnocêntrica e fascista como: "a frustração, o isolamento, a projeção, a paranoia e a rigidez cognitiva", dentre outras, levam o indivíduo, fatalmente, ao desenvolvimento de traços autoritários (Estramiana; Severiano, 2003, p. 21) Os estudos sobre a "Personalidade Autoritária" indicam que

(...) o autoritarismo e o dogmatismo possuem características em comum, tais como a rigidez e a inflexibilidade de pensamento, tendo como fundamento a intolerância. O fanatismo, a discriminação, a distância social, o preconceito, as atitudes racistas e o etnocentrismo frente aos negros, aos judeus, ou aos estrangeiros revelam formas de intolerância características 
da personalidade autoritária e dogmática (ESTRAMIANA; SEVERIANO, 2003, p. 22).

Não desenvolvemos somente aspectos negativos da personalidade, psicólogos sociais procederam estudos sobre a "personalidade democrática, tolerante ou produtiva". Como demonstrado

(...)Gordon W. Allport (1954: 458ss) assinala que um nível educativo alto, capacidade empática, autocompreensão ou conhecimento de si mesmo, capacidade de auto culpabilidade e de simpatia pelos oprimidos, a tolerância à ambiguidade e valores estéticos, sociais, religiosos e teóricos sobre os econômicos e políticos constituem-se em traços característicos do que ele tipifica como personalidade tolerante, em oposição à personalidade autoritária (ESTRAMIANA; SEVERIANO, 2003, p. 22).

Os estudos que Marcuse desenvolveu sobre a questão da tolerância, ao analisar as sociedades industriais modernas que utilizaram uma tolerância passiva diante dos abusos e do autoritarismo ou mesmo de uma certa resignação diante de atos intolerantes, proporcionam um efeito de falsa tolerância, produto de uma falsa consciência. No entanto, ele propõe uma tolerância com base em uma reflexão crítica que produziria uma tolerância libertadora, que consiste em adotar uma máxima: "intolerância com os intolerantes" (ESTRAMIANA; SEVERIANO, 2003, p. 22/23). Para Habermas, a proposta de uma "ética comunicativa" ajudaria na autonomia de uma ação baseada na vontade e não da coação. A proposta de Habermas de uma razão dialógica ajuda na promoção de um sistema democrático e utiliza a tolerância como base fundamental. O conceito de ação comunicativa é construído por Habermas a partir de

a) Uma reformulação da dimensão interpretativa da ação social de Weber, como processo de negociação das definições da situação susceptíveis de consenso. Neste ponto é importante assinalar que, para Habermas, o tipo de interação a que se refere o conceito de ação comunicativa, apesar de se coordenarem mediante atos de fala, não podem ser subsumidos a estes. Tampouco a ação comunicativa se esgota no ato de entendimento efetuado em termos de interpretação.

b) Uma incorporação dos conceitos de ação racional com respeito a fins de Weber, de ação social regulada por normas de Parsons e Durkheim e de ação dramatúrgica de Goffman y Garfinkel, assim como de pressuposto 
wittgensteiniano de um meio linguístico no qual se refletem como tais as relações do ator com o mundo. Este pressuposto implica a acessibilidade da problemática da racionalidade pelo próprio agente (ESTRAMIANA; SEVERIANO, 2003, p. 22 apud HABERMAS, 1981, p. 37-38).

O pensamento de Habermas e dos demais pensadores frankfurtianos é uma crítica ao lluminismo a partir da razão com elemento crítico, constituidor da história e que não deve ser negligenciada pelos irracionalismos. Sua crítica dirigir-se à razão instrumental, positivista, mas não à totalidade da razão, a qual, de acordo com Marcuse (1978), representa a mais alta potencialidade da existência humana. A tolerância tem como função regular as relações entre os indivíduos e entre estes e as instituições tanto religiosas, como do Estado, constituindo-se, pois, numa construção histórica e cultural. A tolerância, como luta contra a intolerância, busca a superação da falta de ética de nossas sociedades nos últimos acontecimentos históricos.

Os que militam pelos Direitos Humanos acreditam que é a forma de lutar contra as injustiças que afligiram e afligem a humanidade, tais como ficou demonstrado por Sérgio Gomes da Silva: "formas de discriminação, preconceito, desigualdades, injustiças sociais, políticas e econômicas, violência física ou psicológica e impunidades de toda sorte". Podemos incluir a questão da intolerância religiosa contra àqueles que são fiéis das religiões afro-brasileiras e a escalada de violência praticada por grupos intolerantes que rotulam os afro religiosos de adoradores de demônios, cultuadores de ídolos e serviçais das hostes do mal. Enfim, os crimes que são reiteradamente praticados pelos cristãos contra as religiões de comunidades tradicionais de terreiro caracterizam uma falta de tolerância para com o próximo, um desafio às autoridades nacionais ao utilizarem de meios de abordagem próprios ou o auxílio de criminosos para expulsarem lideranças 
afro religiosas de seus terreiros e a busca de uma supremacia política para implementar o domínio dos desígnios de suas lideranças para toda a sociedade.

Quando Sérgio Gomes da Silva elaborou seu artigo o Brasil havia uma perspectiva de construção de um país que objetivava "recrudescer a solidariedade, a dignidade, o respeito e a tolerância pelo outro, independente da raça, cor, sexo, cultura, partido político, crença religiosa ou status social na mesma sociedade dita democrática" (GOMES, 2009, p. 79). A democracia no Brasil, mesmo durante aquela época, já estava sendo descaracterizada a cada ataque aos praticantes das religiões de matriz africana. Daí devemos indagar se os direitos à liberdade e a tolerância religiosa são realmente respeitados neste quadro de perdas de direitos que foi formado neste país. A modernidade incluía a questão dos direitos humanos para a melhoria das relações sociais conforme escrito Sérgio Gomes da Silva

(...) a compreensão de dignidade e respeito pelo seu semelhante e a compreensão das nossas diferenças através do princípio de igualdade, sobretudo de igualdade de direitos (e de deveres), do respeito mútuo, da cidadania, dos ideais democráticos, dos princípios humanitários, da compreensão e aceitação do outro como um de nós, mesmo que este seja diferente em suas singularidades. (GOMES, 2009, p. 81).

A questão da igualdade é refutada, segundo Gomes, pela filósofa Hannah Arendt, que demonstrou que não somos iguais; essa igualdade ocorre desde que tenha uma decisão ao qual garanta a todos direitos iguais, isto é, uma construção por convenção coletiva da comunidade ao qual pertença o indivíduo que queira a igualdade, a soma dessas vontades individuais levou ao constructo coletivo de igualdade (GOMES, 2009, p. 81).

Devido às desigualdades presentes na sociedade brasileira e, principalmente, aos atos intolerantes dos praticantes das religiões afro-brasileiras, que sofrem uma 
perseguição e demonização de suas práticas religiosas, Gomes evidencia as afirmações de Peter Fry, que ressalta

\begin{abstract}
Nas sociedades que se apresentam como democracias liberais, o ideal de igualdade de todos perante a lei é regularmente ameaçado pela distribuição desigual de poder e influência e pela hierarquia moral das categorias sociais e grupos com base em características especificas, reais e assumidas. A riqueza pode corromper e, a despeito da superação da criminologia lombrosiana, mulheres e pessoas de cor, membros das "minorias sexuais" e imigrantes tendem a sofrer tratamento distinto da polícia e do judiciário geralmente contra seus interesses (GOMES, 2009, p. 82 apud FRY, 2000, p. 207).
\end{abstract}

Gomes orienta que as desigualdades ressaltam no Brasil devido a nossa sociedade das aparências, que estabelece no consumismo a característica de escancaramento de nossas dessemelhanças. Nisso, a nossa sonhada igualdade parece distante, devido ao nosso passado de escravização escancarada para uma escravização modernizada. O fato é que, apesar de todos os problemas, os homens lutaram e lutam para obter uma igualdade jurídica que evitaria um aumento considerável de pessoas desamparadas e sem acesso a uma real cidadania (GOMES, 2009, p. 82).

A privação da cidadania afeta o estatuto político, afasta a possibilidade de uma igualdade respeitando as diferenças e, uma vez afastado o princípio de igualdade, surgem os totalitarismos e a capacidade de minimização das condições de tratamento do humano, levando-o a descaracterização da espécie humana. O princípio de igualdade de todos perante a lei, de acordo com Sérgio Adorno, é a garantia de que todos os cidadãos serão submetidos às mesmas leis sem exclusão e a inclusão de todos os atores sociais da sociedade que pretenda ser igualitária. Essa igualdade visa uma isonomia de todos e a garantia de que todo e qualquer ser humano tenha a sua condição de humano assegurada (Gomes, 2009, p. 83). 
A questão da violência, segundo Gomes (2009), ela é um "subproduto da decantação do preconceito, da discriminação e da intolerância contra as minorias identitárias", o autor utiliza uma expressão de Burke (2000) que resume essa questão de uma violência específica, isto é, "violência das mínimas diferenças". Gomes (2009) entende que o desrespeito destas minorias está na desconsideração das identidades, ao citar Hall (2000), aponta para a questão: “(...), quem precisa de identidade em um mundo onde ao invés da corrosão do caráter verificamos agora a corrosão das identidades sociais?".

Ao concentrar-se na sua identificação identitária, isto é, grupos de indivíduos despertando no seu processo identitário, provocará conflitos com outros grupos, principalmente, o grupo dominante, como comprova Gomes, demonstrando que "outros grupos que toleram pouco esse fechamento identitário, o que desloca o foco da violência, do preconceito da discriminação para o problema da intolerância, apesar de não justificá-la."

Gomes citará Freitas (s/d) na qual afirma que: “(..), a definição do que seja 'intolerável’ pode variar na mesma medida em que variam as identidades sócio culturalmente construídas". Portanto, essa é uma discussão promovida com a intenção de apontar para a questão da tolerância ou intolerância dependente dos problemas ligados as diferenças identitárias e da manifestação de grupos identitários que causam repulsa por grupos ditos "superiores" e que menosprezam ou atacam a manifestação dessa identidade grupal a ser hostilizada pelo bem da identidade de um grupo dominante (GOMES, 2009, p. 84).

A questão da inclusão é algo que deve ser considerado problemático em uma sociedade que não respeita a questão da igualdade e muito menos tolera as diferenças, ou seja, "(...) a inclusão não é a eliminação da diferença, mas o 
reconhecimento da diferença; a exclusão, essa sim, é o não reconhecimento do outro (...)" (PINTO, 1997 apud FREITAS, s/d).

A sociedade brasileira tem mecanismos de exclusão que utilizam de ferramentas aos quais subjugam muitos sujeitos excluindo-os através do uso da violência, para formar nessa sociedade o que o psicanalista Jurandir Freire Costa chamou de um recurso denominado "ética do alheamento do outro", isto é, o alheamento é uma atitude de distanciamento cuja hostilidade e a perseguição de muitos são substituídos pela desqualificação moral de um sujeito. Mesmo que esse sujeito obedeça às leis, contribua para o bem comum e não prejudique a coletividade com suas ações ele passa a ser desqualificado, hostilizado e subjetivado, com o apoio dos dominantes que incentivam essas ações para continuar o processo de exclusão das minorias neste país.

Gomes (2009) cita Umberto Eco que sugere uma única ética possível no mundo moderno é a ética do respeito aos nossos corpos, ou seja, nosso relacionamento com um mundo é extremamente desigual e a única coisa que temos é o nosso corpo, ao qual não aceitaríamos nenhuma forma de violação daquilo que nos restou como referência de individualidade (GOMES, 2009, p. 85).

Cabe nesse momento verificar a nota de Gomes que citará Zigmunt Bauman que estudou o conceito de tolerância na teoria liberal retomando os conceitos de Susan Mendus, onde ele afirma que

(...) a tolerância implica na repreensão moral da coisa tolerada e que pode ser alterada, ou seja, tolerar o outro implica que é para descrédito dele o fato de não mudar aquela sua característica que é o objeto da própria tolerância." Cito Bauman: "A tolerância não implica a aceitação do valor do outro; ao contrário, é mais uma maneira, talvez mais sutil e astuta, de reafirmar a inferioridade do outro e oferecer um pré-aviso da intenção de eliminar a alteridade do Outro - junto com o convite ao Outro para cooperar na realização do inevitável. A famosa humanidade da política da tolerância não passa de consentimento em adiar o acerto final de contas - com a condição, no entanto, de que o próprio ato de consentimento reforce ainda 
mais a ordem de superioridade vigente" (GOMES, 2009, p. 93 apud BAUMAN, 1999, p. 300).

O que está em jogo na construção de uma política de tolerância, aqui no Brasil, é apenas rebaixar as religiões afro-brasileiras aos parâmetros de idólatras e adoradores de tudo, menos do Deus único e verdadeiro, o que configuraria na situação proposta por Bauman de tolerar para depois de um determinado momento acertar as contas e rebaixar as comunidades tradicionais de terreiro demonstrando a superioridade dos cristãos em comparação com os que não aceitam a verdade cristã.

Enquanto vivenciamos um cotidiano de violência e desprezo por parte da sociedade em relação às religiões afro-brasileiras, devemos compreender que os atos violentos aos afro-religiosos é como Arendt confirma de "resultante do ódio irracional contra os seres humanos". Ainda, de acordo Arendt

(...) a violência frequentemente pode ser associada ao ódio irracional ou patológico, do mesmo modo que qualquer outro sentimento humano. Porém, sugere a autora, é possível criarmos condições de desumanização do ser humano como, por exemplo, nos campos de concentração, nas ações de tortura, em estados de fome ou de miséria humana absoluta, mas isto não significa que a desumanização seja resultante única e exclusivamente do ódio ou da violência (GOMES, 2009, p. 85).

Em nota, ao final do artigo, Gomes cita o filósofo Giorgio Agamben, que cunhou o termo "estado de exceção", ou seja, a intolerância e a violência funcionam para perseguir os indesejáveis submetendo-os à desumanização

\footnotetext{
um estado absoluto no qual o ser humano é destituído do seu status de cidadão, podendo vir a sofrer qualquer tipo de violência física, chegando à morte sem que o seu agressor possa ser punido pelo seu crime. É um estado sem lei, na qual a figura do "homem sagrado" (homo sacer) assume na contemporaneidade o lugar do poder soberano. (GOMES, 2009, p. 94 apud AGAMBEN, 2008)
}

Ao citar Norberto Bobbio (1992), em sua obra "A era dos direitos", Gomes (2009) revela que Bobbio faz referência a dois tipos de tolerância: "a tolerância 
religiosa e a tolerância por motivos sociais e étnicos", que estão ligados aos problemas da discriminação e do preconceito. Ainda de acordo com Bobbio (1992), a tolerância religiosa deriva da crença de possuir a verdade e, no caso da tolerância por motivos étnicos e sociais, derivaria de um preconceito. Para Bobbio, tanto tolerância e quanto a intolerância têm aspectos positivos e negativos

Em sentido positivo, tolerância se opõe a intolerância em sentido negativo;
e, vice-versa, ao sentido negativo de tolerância se contrapõe o sentido
positivo da intolerância. Intolerância em sentido positivo é sinônimo de
severidade, rigor, firmeza, qualidades todas que se incluem ao âmbito das
virtudes; tolerância em sentido negativo, ao contrário, é sinônimo de
indulgência culposa, de condescendência com o mal, com o erro, por falta
de princípios, por amor da vida tranquila ou por cegueira diante dos valores.
[...] Tolerância em sentido positivo se opõe a intolerância (religiosa, política,
racial), ou seja, à indevida exclusão do diferente. Tolerância em sentido
negativo se opõe a firmeza nos princípios, ou seja, à justa ou devida
exclusão de tudo o que pode causar dano ao indivíduo ou à sociedade
(BOBBIO, 1992: 210-211) Para Gomes, o que está no cerne do conceito de tolerância é o reconhecimento do outro como semelhante, irmanado e humanizado. É ter ética ao relacionar com o próximo e buscar um mundo pautado no igualitarismo. Espera-se que essa igualdade funcione como ideal regulador do que uma prática totalitária. Tolerar é aceitar o homem de acordo com sua definição de homem que desenvolveu uma consciência individual e ao mesmo tempo uma consciência coletiva que não permita o ensino do ódio. O que Gomes espera, neste caso, é um homem sem defeitos e sem incongruências. Em muitos casos, o ser humano tem demonstrado falhas, principalmente, os crimes violência, que, no caso específico, a intolerância religiosa contra os praticantes das religiões afro-brasileiras tem sido uma constante na sociedade brasileira (Ibid., 86). Gomes citará Bauman para demonstrar a relação entre tolerância e solidariedade

Não há solidariedade sem a tolerância da alteridade do outro. Mas a tolerância não é condição suficiente para a solidariedade. Nem a solidariedade uma consequência predeterminada da tolerância. Certo, não 
se pode imaginar crueldade praticada em nome da tolerância; mas há um monte de crueldade que a tolerância, através da arrogante despreocupação que alimenta, torna mais fáceis de cometer. A pós-modernidade é um lugar de oportunidade e também de perigo - e ambas as coisas pelas mesmas razões (GOMES, 2009, p. 94 apud BAUMAN, 1999:277-278).

Gomes vai enfatizar, através de Bobbio, que o intolerante não dá importância à verdade, não quer saber do dilema tolerância ou intolerância e não considera as opiniões de outros válidas, enfim, tolera por esconder as suas reais intenções. As ações intolerantes não devem ser alvo de elogios e muito menos aceitáveis em uma sociedade que presume ser democrática. Gomes sugere a proteção de liberdades individuais e coletivas das minorias, que pode ser feito através de ações coletivas na sociedade civil (grupos, ONG's, associações de bairros) na promoção de políticas públicas com a ajuda de mecanismos nacionais e internacionais para a promoção da tolerância religiosa e combate à discriminação e, também, a violência que contribui para os atos de intolerância aos adeptos das religiões de matriz africana no Brasil.

Ao considerar que, da Revolução Francesa até os dias atuais, pouco se escreve sobre a solidariedade e a defesa dos Direitos Humanos, Gomes aponta o filósofo norte-americano Richard Rorty com a melhor proposta sobre a questão de a solidariedade como dever moral a todos os seres humanos, além dos questionamentos sobre a modernidade. De acordo com Rorty, "o sentimento de solidariedade depende necessariamente das semelhanças e das diferenças que surgem em função de um determinado grupo," ou seja, a solidariedade não é um mero amor ao próximo ou os ideários humanistas de Rousseau, a solidariedade é o reconhecimento da ideia de pertencimento a uma comunidade tradicional.

A solidariedade, para Rorty, proporciona um progresso moral, pois admitimos que o Outro sofre, tem problemas diversos e é humilhado. Ao incluir o "diferente" do 
nosso grupo social, aumentamos a nossa possibilidade de acordos e o referencial sobre nós mesmos solidificando nosso progresso moral (GOMES, 2009, p. 87).

Gomes vai citar Bauman, que reforça os conceitos de Rorty ao incluir a gentileza para com o Outro, no intuito de evitarmos problemas e criarmos um ambiente propício para a tolerância. Então, a cultura da tolerância é para Bauman

\begin{abstract}
Ser gentil e a tolerância que isso representa como símbolo de comportamento e linguagem podem muito bem significar a mera indiferença e a despreocupação que resultam da resignação (isto é, da sina, não do destino); o Outro não irá embora e não vai ser como eu, mas eu não tenho meios (pelo menos no momento ou no futuro previsível) de forçá-lo a ir-se ou mudar. Como estamos condenados a dividir o espaço e o tempo, vamos tornar a nossa coexistência suportável e um pouco menos perigosa. Sendo gentil, eu atraio gentileza. Espero que a minha oferta de reciprocidade seja aceita; tal esperança é minha única arma. Ser gentil é apenas uma maneira de manter o perigo à distância; como a antiga ânsia de proselitismo é resultado do medo. (GOMES, 2009, p. 88 apud BAUMAN, 1999, p. 248).
\end{abstract}

A solidariedade proporciona a tolerância através da gentileza, evitando a diminuição do Outro, respeitando suas diferenças e considerando a sua alteridade, o que Gomes ressalta citando Bauman

Para revelar o potencial emancipatório da contingência como destino, não
bastaria evitar a humilhação dos outros. É preciso também respeitá-los -e
respeitá-los precisamente na sua alteridade, nas suas preferências, no seu
direito de ter preferências. É preciso honrar a alteridade do outro, a
estranheza no estranho, lembrando (...) que o único é universal, que ser
diferente é que nos faz semelhantes uns aos outros e que só posso
respeitar a minha própria diferença respeitando a diferença do outro
(GOMES, 2009, p. 88 apud BAUMAN, 1999, p. 249).

Gomes revela que Bauman entende que a solidariedade ocorre através de um agrupamento de sujeitos livres, o sentimento de pertencimento é coletivo e não identitário. O Reconhecimento, neste caso, é o da cidadania de um grupo de sujeitos livres e pertencentes a uma comunidade que reconhece as diferenças individuais e aceitam-nos como sujeitos com direitos (GOMES, 2009, p. 88).

A ideia de liberdade defendida por Bauman é citada por Gomes, na qual é colocada desta forma: "Só uma sociedade livre pode propor que as diferenças 
hierárquicas não imponham um sentido de valor entre os hierarquizados", isto é, isso aparece na "ideia de hierarquia social", formando grupamentos ou segmentos sociais e os indivíduos em dois novos grupos: "os incluídos" e os "excluídos". A noção de liberdade, conforme Bauman (1989), "é uma criação histórica e social", essa noção deve estar condicionada a integração do indivíduo na sociedade com o devido reconhecimento do grupo humano que tem os mesmos direitos, valorização e oportunidades. De acordo com Bauman

\begin{abstract}
A liberdade pressupõe uma relação social, uma assimetria de condições; essencialmente implica em diferença social - pressupõe e implica a presença da divisão social. Alguns podem ser livres somente na medida em que exista uma forma de dependência a que possa esperar fugir. Ser livre significa poder ir para onde for (...), significa também que há pessoas que estão presas à sua casa e a quem é negado o direito de se deslocar livremente (GOMES, 2009, p. 89 apud BAUMAN, 1989, p. 21/22).
\end{abstract}

O sentido de "reconhecimento" entre os humanos aumenta a nossa tolerância, amplia a capacidade melhorar a condição de evitar os conflitos e os atos de intolerância dada a possibilidade de 'sentimento de tolerância mútua", dessa forma objetiva-se um ideal de igualdade, de humanidade e de solidariedade humana, o que, para Bauman, significa "ser responsável pelo Outro também significa ser um pouco responsável por si mesmo".

Gomes considera que uma sociedade liberal ideal surgirá do aprendizado para construir novos laços discursivos, surgindo um "desejo de solidariedade" onde reconheceríamos nos outros, nós mesmos, aprendendo a tolerância com esse Outro que é nosso semelhante.

A solidariedade ajuda a construir julgamentos éticos e ter responsabilidade pelas ações, respeitando o Outro e suas crenças para que as nossas também sejam respeitadas, mantendo o ideal de solidariedade e humanidade na construção de uma sociedade tolerante e viável para a convivência democrática, pareceria utópico 
caso não houvesse leis ou organizações governamentais ou civis (GOMES, 2009, p. 89). Contudo, a resistência do povo de santo está presente nos tribunais e cobra os seus direitos de liberdade de religiosa e de respeito às suas formas expressão religiosa para que não sejam constrangidas pelo primeiro cidadão que se acha no direito de quebrar objetos rituais no afã de livrar aquele local do domínio dos demônios e dos seus serviçais.

A sociedade liberal ideal proposta por Richard Rorty, segundo Gomes, é possível, utilizando a solidariedade para com o próximo e romper com as divisões entre diferença e igualdade, tolerância e intolerância para não reproduzirmos atos de violência e aviltamento deste Outro. Compreender que somos seres humanos e que podemos ser solidários e compreensivos com o sofrimento desse Outro que é um de nós colocando me no lugar dos que sofrem e descrevendo o tratamento desumano aos quais foram submetidos para superar esses entraves ao surgimento de uma comunidade solidária e livre.

O tolerar não é a submissão do próximo aos ditames estabelecidos ao tolerado. Ao tolerar, passo a impor condições ao que acredito, aos meus conceitos, enfim, não é possível o estabelecimento de uma tolerância incondicional, não possuímos a capacidade de aceitação do outro incondicionalmente devido a nossas limitações e necessidades da vida.

Devemos considerar que, independentemente das diferenças desse Outro com relação a nós, isso não nos permite agirmos de forma violenta com esse próximo como se fosse alguém a ser eliminado para que sobrevivêssemos. Gomes considera que a aceitação incondicional não deve ser uma espécie de caridade que o tolerante exerce para demonstrar seu controle e autoridade sobre aquele que é tolerado. 
A sociedade livre deve ser uma meta para os cidadãos, só que essa liberdade não deve ser sobre diferenças hierárquicas gritantes, as diferenças devem ser minimizadas para que não ocorra uma situação como a da sociedade brasileira, onde o abismo entre aqueles que ganham pouco em relação àqueles que obtêm melhores rendimentos é algo visível e não representa uma sociedade irmanada e fraterna, e, o que é pior, longe de uma meta próxima a igualdade. A igualdade é o que mantém os lutadores por justiça social nas trincheiras contra a intolerância religiosa contra os fiéis das religiões de comunidades tradicionais de terreiro (GOMES, 2009, p. 90).

Para mudar e transformar Gomes lembrará do ideal de solidariedade que sirva de norte para todas as sociedades no mundo para diminuirmos as diferenças gritantes das injustiças sociais e levar os seres humanos a relações mais éticas e a possibilidade da utilização da igualdade e da tolerância sejam utilizadas para transformações reais e não para uma justificativa burguesa de lucro acima dos interesses da maioria (GOMES, 2009, p. 91).

O problema da liberdade é que ela foi confundida com o liberalismo econômico e o seu atrelamento ao desenvolvimento do capitalismo com as novas formas de relações de produção, determinando uma sociedade que tem os seus processos conforme os ditames do mercado. A liberdade derivada do consumismo, da competitividade e do individualismo, isto é, o indivíduo é aquilo que pode adquirir e o que pode obter como consumidor, de acordo com Barroco (BARROCO, 2014, p. 469).

O condicionamento da liberdade aos ditames da sociedade, voltada para a produção de mercadorias que satisfaçam as necessidades de consumo do indivíduo livre, para consumir, na obtenção de bens e propriedades que garantam uma 
situação de superioridade em relação a maioria de não possuidores é arcabouço para a proteção dessa liberdade do rico proprietário e de sua continuidade de legitimação de suas posses mediante leis de um Estado que forneça uma legitimação para as suas formas de obter o lucro e demais bens.

Por fim, essa estrutura montada para garantir a liberdade e legitimidade das propriedades e, ainda, de individualismo possessivo tornam um campo fértil para uma moral burguesa, uma ideologia mercantil e de uma alienação dos seres pela reprodução de um sistema que funciona graças às normas de convivência baseadas em uma liberdade burguesa e na ocultação de uma liberdade para todos e da falta de um respeito mútuo. (BARROCO, 2014, p. 470).

A tolerância presume 0 direito de ser diferente nas relações sociais e da aceitação dessas diferenças. Contudo, ao propor substituir o termo tolerância por alteridade, Barroco citará Jacquard: "é necessário tomar um rumo completamente diferente e tomar consciência da contribuição dos outros, que se torna tanto mais rica quanto for a diferença em relação consigo mesmo" (BARROCO, 2014, apud JACQUARD, 1997, p. 4). A autora, também, ao citar Cortella, não aceita o uso do termo tolerância que demonstra, ao ser utilizado, que suporto, aguento; ele prefere o termo "acolhimento", isto é, acolho as suas convicções, recebo alguém diferente como eu mesmo. Barroco demonstra que o reconhecimento não é mudar de opinião ou o jeito de ser do outro, e conforme é demonstrado por Vásquez, aceitar o direito do próximo a ser diferente e nisso nunca haverá consenso (BARROCO, 2014, p. 471).

A relação social da tolerância não é de enfrentamento com o diferente, a diferença é respeitada, mas uma relação social também ocorre na intolerância, só que de atitudes opostas à da tolerância, com negação da diferença, a exclusão da 
identidade do próximo com a nossa verdade sobre esse outro e suas intenções maléficas. Barroco voltará a questão da liberdade liberal com a máxima que a define, ou seja, "a liberdade de um indivíduo termina onde começa a do outro", onde a autora identifica a atitude intolerante do liberal burguês. Ela considera que esse tipo de liberdade individualista não aceita o Outro e a sua presença ou as suas ideias, essa é uma forma de impossibilitar qualquer possibilidade de convivência. Portanto, Barroco define essa liberdade individualista de uma imposição de norma de convivência intolerante. Ao que parece, essa constatação da autora, revela o caráter intolerante da sociedade brasileira, que aceita a pobreza, desde que não venha pedir esmolas ou favores, e mantenha distância (BARROCO, 2014, p. 472).

Outro caso, podemos verificar, é o caso dos fiéis das religiões afro-brasileiras, aceito a sua presença, desde que não porte seus símbolos e não faça seus rituais num espaço público, ou seja, a nossa sociedade intolerante, tem nojo da "macumba", acha um desaforo ter bebidas e danças para louvar suas entidades, orixás e voduns, que para muitos que não entendem veem como demônios ou coisas para serem evitadas e que causam malefícios, os frequentadores são pessoas estranhas e que, não são permitidos dentro dos templos, igrejas e casas de oração que comportam a sociedade cristã que não suporta o homossexual, o travesti, a prostituta e tantos outros atores sociais que frequentam as religiões de tradição de terreiros por serem excluídos da nossa sociedade brasileira. O que é até estabelecido pelas leis brasileiras que excluem expressão religiosa afro-brasileiras ao rotulá-los de crimes como charlatanismo, curandeirismo e perturbadores da ordem e da saúde da população, como demonstramos ao citar a legislação que reforça a guetização dos atores sociais ligados às religiões de comunidades tradicionais de terreiro. Enfim, o desejo da sociedade brasileira e de seus governos 
sempre foi impedir os afro-religiosos de demonstrarem suas crenças. No entanto, veremos que a reação do povo de santo está na busca pela sua liberdade religiosa, da vitória no STF que permite o abate religioso, nas indenizações sobre a IURD, devido a publicações das fotos de mãe Gilda e tantas outras reações que dariam obras e mais obras sobre a reação afro em relação aos ataques intolerantes da sociedade brasileira e de setores mais radicais do neopentecostalismo brasileiro que trava a sua "batalha espiritual" contra o que eles acham de serviçais dos demônios.

Barroco lembrará de Marcuse e seu conceito de "falsa tolerância", muito comum nas ditas democracias capitalistas que possuem organizações e atores totalitários promovendo uma desigualdade regida por instituições. Essas instituições funcionam para manter a repressão aos indesejáveis e aqueles que aspiram por liberdades e transmitem a sensação de paz e de imparcialidade, porém o controle ideológico e a falsa tolerância permitem uma manutenção dos ditames fascistas nos episódios diários de repressão e divulgação destes atos, principalmente, por um mídia venal que veicula programas para agradar os intolerantes e divulgar ações de repressão no uso da força pelo Estado contra aqueles que reivindicam direitos. A autora remete a autoria desses ataques a democracia no Brasil e o levantamento desse Estado de "falsa tolerância" por teóricos da direita que promovem na mídia nacional essa perseguição aos Outros, que representam os movimentos sociais, os setores progressistas, as forças políticas de esquerda e os militantes dos direitos humanos, como os inimigos da paz e da família brasileira, enfim, um mal a ser eliminado (BARROCO, 2014, p. 470).

Barroco indaga sobre tolerar o intolerável, isso é possível? Ela responde essa questão utilizando Bobbio, "a tolerância absoluta é uma pura abstração" (BARROCO, 2014, apud BOBBIO, in VÁZQUEZ, 1999, p. 120). A autora aponta para 
as práticas culturais que, infelizmente, aconteceram e pode vir a ocorrer devido a essa tolerância aos atos intoleráveis como: genocídio, racismo, etnocídio, tortura, fome, guerra, trabalho escravo, fundamentalismo religioso e diversas formas de violações dos direitos humanos (BARROCO, 2014, p. 475).

De acordo com Barroco, a ética possibilita o ser sair da individuação e ligar-se a um humano genérico através de uma atividade universalizante. A liberdade de escolha possibilita a valoração de escolhas que possibilitam uma ação ética. A liberação de forças dos valores que permitem a humanidade lutar contra as situações deploráveis que são sustentados por irracionalistas e amantes da violência e da degradação do humano. A autora pondera sobre a riqueza humana trabalhada por Marx, que foi a dominação do homem sobre a natureza e sobre a sua própria natureza, isto é, a riqueza é o desenvolvimento das capacidades criativas do homem para o seu crescimento ao longo de suas conquistas realizadas no decorrer do tempo histórico (BARROCO, 2014, p. 476).

Ao concretizar conquistas como a Declaração dos Direitos Humanos de 1948, após a Segunda Guerra Mundial (1939 - 1945), permitiu-se a construção de limites para ações intoleráveis praticadas pelos apoiadores do nazifascismo, as violações dos direitos humanos possibilitou a criação de leis nos âmbitos nacionais e internacional baseados nas conquistas emancipatórias e de valores construídos pelos homens alicerçados na tolerância que não tolerará atitudes desumanizantes como necessárias e fundamentais para as conquistas expansionistas dos imperialistas capitalistas (BARROCO, 2014, p. 477).

A defesa da liberdade e da diversidade de práticas e ideias dos indivíduos é proposta por Barroco em contradição as práticas que negam a liberdade e a humanidade do outro com um posicionamento neutro diante de crimes e violações 
da dignidade humana. A proposição de leis e documentos acerca dos direitos humanos deve ser abrangente de reivindicações dos movimentos sociais, das diversas formas de manifestações culturais permitindo a emancipação humana, onde a noção de humano é medida pelo próprio homem. Segundo Barroco, o relativismo ético com a negação irracionalista e niilista da ética, anula a capacidade de escolha e de demandas sobre escolhas de valor. Ética, razão e ação política, não têm sentido quando vigora uma liberdade individualista. A multiplicidade das capacidades humanas pode produzir, ao mesmo tempo e ao longo da história, riquezas e desigualdades, humanização e barbárie (BARROCO, 2014, p. 478).

A autora conclui que a liberdade liberal tem uma falsa noção de respeito ao outro e, que, na verdade, ela exclui o outro. A liberdade real requer sociabilidade, o enfrentamento das condições adversas a liberdade real em que todos são respeitados na sua diversidade com uma igualdade que não nega o pluralismo da sociedade, admite a diversidade de opiniões, mesmo sendo conflituosas e complexas, mas voltadas para a construção de um projeto societário de universalização dos valores plurais considerados (BARROCO, 2014, p. 479).

A tolerância, de acordo com Thomas M. Scanlon, requer a aceitação dos outros mesmo que não tenhamos concordância com as suas formas de ser ou agir. O necessário é ter uma atitude de aceitação e uma outra ação de oposição descomedida. Essa ação intermediária transforma a tolerância em ato complexo, parece algo comum entre os diversos autores, mas não há como tolerar tudo (SCANLON, 2009, p. 31).

Scanlon abordará a tolerância religiosa que ele considera como uma forma de tolerância difícil. Ele considerará a tolerância religiosa como algo recomendável por não achar relevante a questão religiosa. Entretanto, nossa sociedade leva a questão 
religiosa muito a sério. O Brasil é um país em que a religião é algo que gera muitas desavenças e desentendimentos. Scanlon citará os termos dos dois princípios da Primeira Emenda da Constituição dos Estados Unidos: "Não poderá o Congresso legislar no que diz respeito à oficialização de uma religião, ou proibir a livre prática religiosa" (SCANLON, 2009, p. 32). As questões levantadas pelo autor são pertinentes e ao mesmo tempo necessárias: qual a necessidade de instituir um credo oficial? A tolerância como aceitação ou trégua aos conflitos religiosos é viável? Quais os custos da tolerância religiosa? O que a tolerância religiosa requer?

Respostas para essas questões existem, mas qualquer resposta trará uma será vaga em aspectos fundamentais. Entrementes, o Estado não poderá dar privilégios a um grupo em detrimento do outro, ou seja, o Estado não pode apoiar, direta ou indiretamente, organizações religiosas. A questão da "não-oficialização" é uma forma de tolerância religiosa, pois não o privilégio de nenhuma forma de religião (SCANLON, 2009, p. 33).

De acordos com Scanlon, uma sociedade que promove a qualificação religiosa como critério de ocupação de cargos públicos não pode ser considerada justa ou tolerante. A ocupação de cargos públicos motivadas por esta indicação religiosa desagrada a sociedade e provoca a sensação de um Estado teocrático ou um Estado que privilegia o religioso nas formas de consagração de práticas de tratar os desiguais como pessoas fora da vontade dos iguais. O autor considera que a tolerância é "aceitar como iguais" os diferentes de nós. Uma ideia de igualdade seria a questão eleitoral, votar, buscar votos e, talvez, ser votado, isto é, disputar cargos. No entanto, o que o autor busca é a política informal da vida social (SCANLON, 2009, p. 34). 
O que Scanlon defende uma sociedade tolerante como aquela que tem a sua política informal democrática, que para Ele envolve atitudes e, em alguns casos, essas atitudes não são aceitas. Para o autor o uso de determinadas atitudes de "imposição da moral" para evitar que ações das pessoas aos quais discordamos manifestem seus atos na sociedade, neste caso, a ação de censura visará uma proteção da sociedade. A liberdade de expressão não justifica permitir tudo e não restringir absolutamente nada, ou seja, o agir privado não pode ser totalmente público, por mais desejos libertários que o indivíduo possa ter (SCANLON, 2009, p.35). No entanto, Scanlon vê riscos na tolerância religiosa e tem preocupações sobre a imposição legal da moral ou a restrição para impedir que a sociedade seja deteriorada. Ele não concorda com restrições da vida particular dos indivíduos como forma de controle dos costumes. A moral aplicada de forma legal funciona como uma armadilha que resulta em intolerância, daí a crença do autor nos perigos da tolerância, devido a altos valores em jogo.

Segundo Scanlon (2009), ao indagar se vale a pena valorizar a tolerância, e, ao considerar ela uma saída satisfatória na relação com os concidadãos, ele dará preferência as atitudes tolerantes. Ele considerou essa preferência devido aos intolerantes recusarem a convivência e reivindicarem os seus próprios valores e sua forma de vida. A tolerância envolve uma relação mais interessante e atraente para grupos opostos em uma sociedade. O autor considera que qualquer sociedade terá conflitos, mas a tolerância pode representar um reconhecimento comum, mesmo com as diferenças e a possibilidade de conflitos, o fato de reconhecermos os demais membros da sociedade com os mesmos direitos afasta as rivalidades e disputas (SCANLON, 2009). 
O que a intolerância faz, de acordo com Scanlon, é a negação da plena filiação aos "outros", ou seja, rejeitar a tolerância seria uma alienação aos direitos dos concidadãos, isso só serve para a questão da convivência pública. Quanto a um partido político ou determinado grupo religioso tem a sua organização conforme os ditames dos membros internos, quem não concorda com esses ditames, pode ser expulso, nesse caso não configurará uma intolerância a atitude grupal particular (SCANLON, 2009, p. 38)

O que Scanlon quer demonstrar com a tolerância é questão dela aplicada na sociedade política, o que está em jogo nesta situação são bens preciosos para a constituição de uma cidadania plena, tais como: "o direito de voto, de ocupar cargos públicos e de participar no fórum público", o problema de acordo com o autor é a retirada de direitos e a negação da cidadania por motivos religiosos. As limitações ao exercício da cidadania por motivações religiosas são práticas intoleráveis dentro de uma nação e para todos os nacionais, mas não é um problema caso as proibições configurem normas privadas de grupos privados e regras privadas (SCANLON, 2009, p. 39).

Scanlon é crítico da ascensão da direita cristão e suas implicações contra os direitos das minorias e a insistência em fazer valer a vontade dos cristãos. Ele evidencia uma questão importante, é fácil ver intolerância nos adversários, mas é difícil verificá-la em nós mesmos. Daí a reação do autor a questão ensino do criacionismo nas escolas, a proposta de orações nas escolas, a defesa de retirar "In God WeTrust"19 das notas estadunidenses e apoio ao fim da prática de orações em eventos públicos. Scanlon defende um Estado mais secular, e não esconde a

19 “Acreditamos em Deus” (tradução livre) 
tomada de partido em defesa de uma "não-oficialização" da religião na prática do Governo dos Estados Unidos (SCANLON, 2009, p. 40).

De acordo com Scanlon, caberiam algumas questões: "seria impor o comportamento tolerante e impedir que o intolerante aja conforme suas crenças?". Neste caso não, pois demandar por tolerância não significa uma autorização para realizar tudo o que acredito ser o certo. Ainda, "é intolerante adotar a tolerância como doutrina oficial?" Outra indagação: "É intolerante se ensinar a tolerância nas escolas públicas e promovê-la em campanhas de conscientização patrocinadas pelo Estado?" O autor acredita que não há problema dada a legitimidade da defesa da tolerância na sociedade e nos benefícios que a tolerância traz para pessoas e grupos sociais.

Uma outra questão, "é contrário à tolerância negar aos intolerantes a oportunidade que outros possuem de enunciar seus pontos de vista?" Segundo Scanlon (2009), tolerar os intolerantes é algo irrealizável. Como podemos aceitar a opinião de um grupo que deseja a sua eliminação e a dos demais que comungam de sua fé ou ideias. A tolerância só terá sentido, de acordo com o autor, com a distinção entre a atitude tomada por nós com relação aos nossos opositores e a atitude com relação ao que é defendido por quem nos opõem, não que os opositores tenham razão, mas como concidadãos terão o direito de serem ouvidos.

Scanlon (2009, p. 42) citará Voltaire e sua questão do direito à fala, ou seja, o direito de voz, isto é, o reconhecimento de cada um pela capacidade voz e vez, oportunidades, o que o autor chama de direitos específicos, o que pode levar a indeterminação dos direitos mais formais, que envolverá dois problemas. Uma questão conceitual. Tolerância não é um sistema particular de direitos, não é apenas direito à livre expressão e associação, direito à privacidade e direito ao livre 
exercício da religião. Isso, segundo Scanlon, não é o ideal, apenas aceitável. O autor prefere um espírito da tolerância que seria uma forma de espírito de conciliação.

Outra questão é política. Scanlon considera que há pouco incentivo na política para a conciliação, pois existem razões para não a buscar devido as fronteiras da tolerância são fluídas e ao tentar demarcá-las são auferidos poderes aos opositores. As regras de tolerância funcionam como uma importante estratégia política (SCANLON, 2009, p. 43).

Para Scanlon, a ideia de tolerância pode provocar reações: o desejo de proteger excluídos e o desejo de proteger o sistema. Esse sistema de tolerância só funcionará se for valorizado e protegido contra a erosão. O sistema uma vez guardado terá que ser fortemente abastecido de referenciais fortes e abrangentes, mesmo que pareça uma questão aberta, vale defender um grupo de contestações às regras de tolerância (SCANLON, 2009, p. 44).

Scanlon finaliza com uma questão: há outras formas, não prejudiciais ao sistema de tolerância, pelo qual o respeito pelos grupos ameaçados pudesse ser demonstrado? Ao concluir, o autor considera que a tolerância religiosa tem custos e riscos mesmo dentro de uma democracia constitucional e laica. Na política formal apresenta riscos baixos devido aos ditames legais, já na política informal há riscos devido a redefinição da natureza da sociedade. A atitude de tolerância tem dificuldades para ser implementada e aceita quando não há respeito aos direitos do cidadão, mas essa atitude e a busca da conciliação, mesmo sendo difíceis de se manter tornam-se desejáveis para a sociedade.

Já para Bernard Williams, a natureza da tolerância é complexa e difícil de se colocar em prática devido a sua atitude de tolerância baseada na teoria liberal 
(WILLIAMS, 2009, p. 47). O autor explica que as práticas de tolerância motivaram ceticismo e indiferença em relação as religiões. E, para Williams, isso motivou o crescimento de atitudes de tolerância realizadas após o final das guerras de religião. A sensação de que não havia verdade, ou verdade descoberta para os humanos, para validar um credo em relação às outras. Já algumas pessoas compreenderam os desígnios de Deus, ou seja, Deus não determina como é a forma ritual que seja ideal a Ele, desde que os indivíduos o venerem com fé e de maneira adequada a um cristão, não há uma expressão religiosa única e muito menos uma forma especial de cultuá-lo.

A tolerância, desde então, passou a ser uma atitude. Mas, de acordo com Williams, o ceticismo e a indiferença, não requerem uma atitude de tolerância, exige o que Scanlon afirma a respeito da tolerância "requer de nós aceitar as pessoas e consentir suas práticas mesmo quando as desaprovamos fortemente" (SCANLON, 2009, p. 31).

O que Williams quer demonstrar é que a tolerância estabelecida é invocada por um grupo mais poderoso que tolera um grupo menos poderoso, configurando uma relação assimétrica. Neste caso, o autor demonstra o uso da tolerância na prática e não como uma atitude. E a respeito da prática esse autor estabelece que

É a prática da tolerância ou intolerância como um empreendimento político
que introduz a assimetria associada ao conceito, e não as atitudes
subjacentes, quaisquer que possam ser. Uma atitude tolerante, e do mesmo
modo uma disposição tolerante nascida da indiferença, podem ser ambas
obtidas entre grupos que são iguais em poder (WILLIAMS, 2009, p. 48).

Ele considera que uma prática de tolerância é estabelecida quando ocorre uma opinião equivocada sobre um determinado assunto e quando o agente acredita que os equivocados divergem de suas concepções, mas, mesmo com as divergências acha que os equivocados podem manifestar as suas opiniões 
publicamente (WILLIAMS, 2009, p. 49). De certa forma, a tolerância, segundo Williams, implicará na certeza de que o outro não pode sofrer censura pelas opiniões que defende e publica.

Williams (2009) aponta para dois tipos de natureza do direito que concebem a tolerância com diferenças, um direito moral e um direito político. O autor coloca que o liberalismo e os princípios de tolerância permitiriam uma superioridade com relação às perspectivas morais particulares, fazendo desta parte de uma estrutura de respeito e tolerância mútua, que desemboca numa sociedade pluralista estável como a descrita por Rawls, em sua obra Liberalismo político (1993). Ao colocar o ideal de autonomia moral, Williams demonstra que nem sempre um agente público deverá reprimir ou persuadir o indivíduo por atitude pecaminosa, dependera de sua iniciativa moral para mudar de atitude (WILLIAMS, 2009, p. 50). Em outro caso, Williams, coloca uma interpretação na qual a atitude pecaminosa levaria o agente atuar de qualquer forma para persuadir ou mesmo pressionar o indivíduo pecaminoso com ações visando mudança de atitude do pecador para não pecar mais. Contudo, o Estado não deveria atuar nesse sentido dada a sua prática liberal. A crença na autonomia funcionará como uma demonstração de que é possível uma pressão pela mudança do pecador sem uma interferência política direta (WILLIAMS, 2009, p. 51).

Há o caso do agente que desaprova os valores do outro sentindo-se na obrigação de atitudes de censura diante dos fatos apresentados pelas ações repugnantes e pecaminosas. Para ocorrer uma censura moral a argumentação deverá ter um forte ingrediente racional e de atuação privada, para contemplar os requisitos de uma atitude tolerante. Mas, qualquer atitude tolerante dentro da autonomia encerrará uma questão conflituosa de desaprovação ou contenção. 
Williams mostra-nos que os Estados liberais são favoráveis a escolha individual (liberdade de consumo), cooperação social, secularismo (Williams, 2009, p. 52) e eficiência nos negócios. O fato é que a sociedade liberal pode prejudicar valores religiosos e tradicionais, mesmo que ocorra na prática liberal a tolerância em relação a esses valores.

A tolerância religiosa foi fundada na ideia de que a coação das crenças não geraria boas consequências devido a incapacidade do Estado de atingir as convicções mais intimas do indivíduo, no máximo o que se pode fazer um conformismo da pessoa, mas os objetivos dos intolerantes eram obter muito mais que isso. O que Williams confirma é a questão das desavenças entre aqueles que apoiavam a tolerância e os que a rejeitavam, tudo girava em torno da salvação da alma, e, é, neste ponto, que o autor vê uma inflexão da autonomia, que, neste caso, é defendida por aqueles que invocam-na com relação entre os indivíduos e Deus (WILLIAMS, 2009, p. 53).

Para aqueles que acreditam na tolerância, a questão da fé coagida não faz sentido, e, de acordo com Williams, "a tentativa de fundamentar a prática da tolerância numa atitude moral orientada pelo valor da autonomia está condenada ao fracasso". Ainda, segundo o autor, o poder político não pode influenciar decisões de foro íntimo, como a questão relacionada a fé de cada um, ou que cada um deveria ter ou não ter, o poder do Estado não deve interferir nessas questões. A defesa da não interferência do Estado sobre essa questão demonstra a tolerância aplicada na prática (WILLIAMS, 2009, p. 54).

De acordo com Williams, a exigência básica de legitimação é o pressuposto para a autoridade agir na interferência sobre um determinado segmento religioso ou não. Esse "algo a dizer", conforme o autor, não significa que a pessoa ou grupo irá 
aceitar passivamente a ação estatal, nem sempre a decisão de legitimação do poder é algo passível de aceitação e conformismo de todos os atores sociais (WILLIAMS, 2009, p. 55).

Williams apresenta o problema da tolerância liberal que pode ser esclarecido da seguinte forma: a questão de controvérsias de crença religiosa ou moral e a relação com o Estado liberal e as minorias, que uma vez no poder passariam a impor sua crença. A aceitação desse grupo será de acordo com a sensatez do Estado liberal, ao aceitar os ditames destes grupos, desde que as liberdades não sejam tolhidas. Quando o grupo minoritário não reconhece o Estado e atente contra ele, a tolerância ao referido grupo deixa de existir e o grupo minoritário passará a ser reprimido.

No caso de uma maioria tentando impor a sua crença ao Estado liberal, segundo Williams, esse tipo de organização estatal estaria correndo risco, caso essa maioria não concordasse com a existência de um Estado liberal através de sua crença. Mas, se a maioria não concordasse com a imposição da crença é possível a continuidade de um Estado liberal (WILLIAMS, 2009, p. 56).

Ainda, segundo Williams, o Estado liberal tem um problema com um grupo que não deseja impor suas crenças, mas as práticas violam os princípios liberais fundamentais. Ele cita o exemplo de um grupo que violaria a igualdade de gênero. Vejamos o que Williams apresenta

\footnotetext{
Mas, neste âmbito, a tolerância liberal se enfraquece de todo modo, e nos encontramos no plano da divergência substantiva (sobre o papel dos gêneros e sobre a natureza da sexualidade, por exemplo), onde o liberalismo simplesmente não consegue evitar se apresentar como "mais uma doutrina sectária". Neste ponto, não há como esperar que o liberalismo possa recorrer a um fundamento superior indiscutível. As únicas considerações de ordem superior que o liberalismo pode usar para pensar sobre o que fazer são os recursos do bom senso político: considerar como as coisas parecem da ótica da minoria (algo em que, de fato, os liberais não são os melhores especialistas); ponderar os custos da coerção em questões
} 
controversas sobre a moralidade, como parte do respeito geralmente saudável do liberalismo pelos efeitos não intencionados do poder coercitivo. Não existe nenhuma razão do porquê de essas considerações deverem prevalecer num determinado caso. No entanto, prevalecem à medida que as práticas de atitudes que produziram isso expressam o tipo de atitude e compreensão políticas já mencionadas (WILLIAMS, 2009, p.57).

Caso ocorra, ainda segundo Williams, a abordagem da tolerância como uma questão política e não como uma questão moral, há dificuldade para uma atitude única para fundamentar a prática liberal.

O Estado liberal apresenta padrões de legitimação e tolerância adequada e características demonstráveis por atitudes como virtudes sociais, tais como: "o desejo de cooperar e de conviver pacificamente com seus concidadãos e a capacidade de ver como as coisas Ihes parecem". O bom senso político, custos e limitações do uso da força coercitiva. Um certo ceticismo, a ausência de fanatismos religiosos, enfim todos esses requisitos ajudam na prática da tolerância.

Enfim, ao encerrar Williams, destaca a questão da tolerância com relação à concepção fortemente moralizadora do liberalismo que tem bases na autonomia do indivíduo e no ceticismo. Na atualidade o liberalismo teria melhores condições legitimadoras sob a ótica da estabilidade modernizadora, de acordo com o autor. No entanto, esse liberalismo de fato, enfrentou e enfrenta crises que certificaram o seu descrédito na aplicação de regras de tolerância, os trabalhos dos psicólogos sociais Estramiana e Severiano (2003) sobre os mecanismos que levam à intolerância certificam essa sensação de desesperança no ser humano e das evidências de um problema de inferiorização para a subsequente dominação do homem pelo homem e com todas as bençãos das religiões cristãs. 


\subsection{AS BASES PSICOSSOCIAIS DA (IN)TOLERÂNCIA}

A intolerância é um fenômeno que ocorre com uma certa frequência no século XX e no nosso século XXI: a hostilidade e crueldade de um grupo frente a outro grupo social devido a diferenças étnicas, culturais, raciais, religiosas e/ou políticas.

O que leva a desumanidade ter uma face e ações empreendidas pelo próprio ser humano? O que levam as pessoas a tomarem atitudes tolerantes ou intolerantes?

Os escritos de Estramiana e Severiano (2009) concernem sobre as raízes da intolerância em sociedades ditas superiores e com os principais traços de evolução e desenvolvimento, demonstrados nos saberes e representações dos Ocidentais, isto é, no seio das sociedades democráticas e tolerantes foram desenvolvidas as principais fórmulas de atrocidades perpetradas no século passado e vivenciadas com certos saudosismos na conjuntura atual. Devemos verificar as possibilidades de atingirmos níveis de intolerância e genocídios, elencados pela teoria proposta por Estramiana e Severiano.

\subsubsection{A submissão à autoridade}

A obediência com uma submissão acrítica à autoridade, que rompe com a tolerância, com o respeito pelo outro, levando-o a provocar danos ao próximo sem quaisquer questionamentos. O estrito cumprimento do dever, sem a devida avaliação da ordem dadas e as consequências nefastas dessas atitudes sugeremnos uma descrença no ser humano.

Os elementos que cometem atrocidades, geralmente, são considerados cidadãos normais. Hannah Arendt, ao observar o julgamento de Eichmann, em 
Israel, em 1961, publicando o livro Eichmann, em Jerusalém (1963), relata que Eichmann não era nenhum monstro, mas uma pessoa normal. O criminoso de guerra que defendia o nazismo acreditava que deveria obedecer às ordens de seus chefes, pois a obediência e o cumprimento do dever são sagrados (ESTRAMIANA; SEVERIANO, 2003, p. 27).

\subsubsection{A banalização do mal}

A banalização do mal, de acordo com Hannah Arendt estava "nos diversos atos rotineiros que tornaram possível o holocausto".

"O que mais nos surpreende e aterroriza é que sujeitos como Eichmann e tantos outros são 'normais'". A normalidade de atos sádicos, como os evidenciados por Zimbardo na prisão de Stanford, levam-nos a detectar condutas sádicas em sujeitos normais (ESTRAMIANA; SEVERIANO, 2003, p. 28).

A normalidade dos atos intolerantes contra as religiões de tradição de terreiro e a respectiva depreciação dos rituais é rotineiro no Brasil o que confirma a banalização das atitudes de setores envolvidos na violência aos praticantes das religiões afro-brasileiras como ato contra as forças do mal.

\subsubsection{Desvinculação entre o ato e suas consequências}

Devemos analisar este aspecto como uma forma de abandono dos princípios éticos e a execução da ordem como "razões de segurança", "crimes de obediência", enfim, o funcionamento do sistema é o que importa as consequências destes atos, mesmo sendo irracionais, isso não vêm ao caso 
Outro pressuposto psicossocial da intolerância é a tendência a ver-se absorvido pelos aspectos técnicos de um ato imoral ou antiético." Quando ocorre o desligamento "entre meios e fins, entre o ato e suas consequências é um aspecto fundamental na inibição dos princípios morais e éticos que deveriam coibir o dano à outra pessoa (ESTRAMIANA; SEVERIANO, 2003, p. 29).

A preocupação apenas com aspecto "técnico-burocrático", independentemente da situação de outras pessoas, atos extremados e eivados de violência e irracionalidade justificando o "progresso técnico" ou "razões de segurança", leva-nos a uma "ditadura da racionalidade tecnológica" sobre o lado humanitário (ESTRAMIANA; SEVERIANO, 2003, p. 29).

"A delegação do pensamento a uma suposta racionalidade do sistema parece ser um fator decisivo na desculpabilização individual (...), mesmo quando são perpetrados atos inumanos", Marcuse define que: “(...) a neutralidade da racionalidade tecnológica se manifesta sobre a política e acima dela, e novamente se revela espúria, pois em ambos os casos serve à política da dominação".

\subsubsection{Degradação da vítima}

Tornar alguém indesejável, merecedor do seu destino e por retirar-lhe a condição de humano "Somente assim é possível explicar como a depreciação pelo outro pode conduzir ao seu aniquilamento" (ESTRAMIANA; SEVERIANO, 2003, p. 30).

O "bode expiatório" é eleito através dos "mecanismos de projeção e frustração da personalidade autoritária".

Por que alguns grupos sofrem maior hostilidade do que outros?

(...) os determinantes internos e externos, ou seja, para além dos traços individuais de personalidade, é de suma importância a consideração a certos fatores socioculturais que nos levam a entender por que, por exemplo, determinados grupos têm sido, historicamente, objeto de maior hostilidade do que outros. Neste sentido, o exemplo dos judeus é 
paradigmático, uma vez que nele confluem uma mescla de elementos religiosos étnicos de forte persistência e, com isto, uma legitimação histórica da intolerância.

Ao negar o tratamento igualitário, tratar determinadas categorias sociais como inferiores, caminhamos a passos largos para o ato intolerante e na total degradação da vítima, como no caso de nossos estudos, qualificá-lo como um "demônio" ou auxiliares dele. Como podemos constatar

\begin{abstract}
Segundo Allport (1954: pp 270-288) há discriminação somente quando negamos a outros indivíduos ou grupos de pessoas a igualdade de tratamento que eles podem desejar, com a condição específica de que esta desigualdade não está baseada em qualidades individuais, mas em categorias sociais. Esta desindividualização das vítimas da intolerância como meros membros de categorias sociais inferiores nega sua condição humana, e, com ela, seus direitos sociais elementares.
\end{abstract}

\title{
3.1.5. Processos de influência social
}

A tolerância não é adquirida por processos simples, como discursinhos vazios e com mero palavrório rebuscado e determinados vernizes de bondade nas palavras.

Uma personalidade autoritária ou mesmo um desses agentes aptos para uma ação intolerante que, por mais absurdo que pareça, cruzamos com um logo na esquina, execrando e vilipendiando um "bode expiatório" fabricado no interior de sua frustração enquanto humano malformado, jamais reuniria condições de tolerar ou mesmo de tratar com dignidade aquele ser odiado por ele.

A tolerância é objeto de aprendizado por influência social, com socialização e convivência saudável para aquele que aprende. Ser tratado com dignidade deveria ser obrigação de todos e quaisquer seres humanos, independentemente de sua origem, condição social, gênero ou religião.

A influência da maioria, segundo Asch (1951), levam, geralmente, a atitudes de submissão diante do apelo do julgamento majoritário. O comprazimento com o 
julgamento leva à adoção de consentimento diante da intolerância, da identificação e de uma internalização certos grupos agem de forma intolerante com base sistema de valores que guiam a conduta do indivíduo. Em outras palavras, o moralismo e o discurso dos "cidadãos exemplares" justificam as insanidades perpetradas contra os indesejáveis.

Já para Moscovici, uma minoria bem firme em seus propósitos provocará mudanças sociais. Esta teoria surge no contexto dos movimentos sociais, nos protestos de 1968. Estas teorias ficaram conhecidas como teoria das minorias ativas e, posteriormente, como teoria da conversão. No entanto, os autores advertem sobre a possibilidade de as minorias transformadoras promoverem tanto atos tolerantes como atos intolerantes.

As seitas e seus processos de convencimento repressores representam riscos para a democracia, a racionalidade crítica e a tolerância como um valor do indivíduo e da sociedade. Os métodos de cerceamento das liberdades dos frequentadores das seitas e estratégias de influência como: o isolamento dos membros frequentadores com relação aos parentes, amigos ou grupos anteriores que frequentavam; a dependência do membro para com os tramites e normas da seita; oferecer meios de diminuição da capacidade de decisão racional e a extrema dependência racional e emocional diante do líder propagador das ideias da seita.

O grupo possui uma força na questão de mudanças, no comportamento dos indivíduos pertencentes ao coletivo com funções de desmanchar a eticidade, a responsabilidade e até mesmo a tolerância e o respeito ao próximo, levando seus membros aos comportamentos distantes da responsabilidade e atos delirantes e malefícios travestidos de ações dignas e responsáveis. 
Fica demonstrado "o poder que o grupo possui na modificação da conduta individual" modificando os "comportamentos e reações distintas daquelas expressas quando estão separados." Atitudes "grupais" permitem um "sentimento de força" e retiram "os sentimentos de culpabilidade" e o "distanciamento" entre os "atos e suas consequências" (ESTRAMIANA; SEVERIANO, 2003, p. 32).

Ao analisar "processos" ligados "ao preconceito e à hostilidade frente a outros grupos distintos do nosso", Sherif (1967) aborda

O primeiro demonstra como a pertença a um grupo com traços distintivos provoca uma identidade endogrupal e uma consequente coesão dos membros do referido grupo. A existência de competências, necessárias à consecução de metas, que encerram posteriores recompensas provoca, em geral, uma hostilidade intergrupal, acarretando a consideração dos membros acabam por não se tolerarem como consequência de sua adesão a grupos diferenciados (ESTRAMIANA; SEVERIANO, 2003, p. 32 apud SHERIF, 1967).

Ao analisar "processos" ligados "ao preconceito e à hostilidade frente a outros

grupos distintos do nosso", Tajfel (1981) aborda

Tajfel, por sua vez, com seu paradigma do grupo mínimo, demonstrou que não é necessário ter competência para que a pertença a um dado grupo provoque um favoritismo frente ao próprio grupo e discriminação intolerância - com relação ao exo-grupo. Os grupos nos provêm de uma identidade social e contribuem para a manutenção de uma imagem positiva de nós mesmos. Esta imagem positiva de si mesmo é mantida pelos grupos através do estabelecimento de comparações seletivas com outros grupos sociais. Os processos de comparação social com outros grupos levam a favorecer a imagem que os membros do grupo têm de si mesmos e a discriminar aos membros de outros grupos com os quais se comparam, especialmente se a imagem do grupo está ameaçada. A intolerância em relação a membros de outros grupos, expressa em termos de preconceito étnico, racial ou de classe, têm sua explicação nos processos de categorização, identidade e comparação intergrupal antes descritos. Perceber o outro como membro de uma categoria estereotipada ou vê-lo como pessoa independente tem consequências claras sobre a (in) tolerância frente a esta pessoa (ESTRAMIANA; SEVERIANO, 2003, p. 32/33 apud SHERIF, 1967).

Freud (1921), na obra "Psicologia de grupo e análise do Ego", propõe que "é somente através da identificação mútua entre os membros da massa e do controle da expansão narcísica que pode haver possibilidade de coesão social". Através da 
“Teoria da libido', ou seja, os 'vínculos dos membros de um grupo e entre estes e seu líder é de natureza libidinal", isto é, os membros sentem-se "amados pelo seu líder". A questão da "idealização" trata-se de colocar o líder na perfeição, "sendo dotado de todas as qualidades ideais do ego" e sobretudo, "isento de toda crítica." A base para essa fascinação vem da "adesão irrestrita observada nas seitas religiosas." No caso do "narcisismo das pequenas diferenças", essa questão assemelha-se ao fenômeno do "bode expiatório", nessa situação "a exacerbação das pequenas diferenças intergrupais", com isso buscavam acabar com as "ambivalências de sentimentos" e formar um mecanismo de "coesão interna" (ESTRAMIANA; SEVERIANO, 2003, p. 33).

Freud afirma sobre a questão da (in) tolerância

Fundamentalmente, na verdade, toda religião é, dessa mesma maneira, uma religião de amor para todos aqueles a quem abrange, ao passo que a crueldade e a intolerância para com os que lhes pertencem, são naturais a todas as religiões. (...) As pessoas que são descrentes ou indiferentes estão psicologicamente em situação muito melhor nessa questão (da crueldade e da intolerância). Se hoje a intolerância não mais se apresenta tão violenta e cruel como em séculos anteriores, dificilmente podemos concluir que ocorreu uma suavização nos costumes humanos. A causa deve ser antes achada no inegável enfraquecimento dos sentimentos religiosos e dos laços libidinais que eles dependem. Se outro laço grupal tomar o lugar do religioso - e o socialista parece estar obtendo sucesso em conseguir isso -, haverá então a mesma intolerância para com os profanos que ocorreu na época das Guerras de Religião, e, se diferenças entre opiniões científicas chegassem um dia a atingir uma significação semelhante para grupos, o mesmo resultado se repetiria mais uma vez com essa nova motivação (ESTRAMIANA; SEVERIANO, 2003, p. 32 apud FREUD, 1921, p. 125)

Os processos indicam que a tolerância e a intolerância são fenômenos ligados à influência social, isto é, de uma maioria ou de uma minoria, ou seja, caracterizados por manifestações ambivalentes, uma dualidade, do bem e do mal. O problema está na concepção de uma ortodoxia racional que não permite uma racionalidade baseada na crítica e, é claro, na formação de grupos que tem como exemplo os moldes de um pensamento religioso. No entanto, os grupos poderiam 
ser até contra as religiões, mas, se na base de sua formação permitir-se o fascínio, a rigidez cognitiva e a razão acrítica, não temos um grupo a serviço do progresso da ciência e da humanidade.

\subsection{PRIVAÇÃO, MUDANÇA SOCIAL E INTOLERÂNCIA}

A intolerância surge devido às frustrações nas expectativas de mudanças dos sujeitos intolerantes.

A intolerância diante do diferente, do ameaçador e, principalmente de grupos excluídos historicamente, como judeus e negros, surgem em momentos de crise financeira ou mudanças sociais, proporcionadas por aqueles que eram excluídos e aparecem como uma ameaça para aqueles que detinham uma situação favorável. As atitudes intolerantes cumprem funções normativas para uma sociedade conservadora e nomeia os "bodes expiatórios" para "normalizar" a convivência no meio social. No entanto, essa privação proporcionará críticas aos padrões dominantes e as atitudes violentas tomadas para a manutenção do status quo desembocará em transformações significativas do ordenamento social.

Podemos inferir que é a natureza humana e depende da cultura. A "essência humana" não define o estado bom ou mal do homem. Dependente de uma relação de difícil solução com a cultura e seus valores, de suas formas de interiorizadas e das condições desta cultura para providenciar atributos aos homens a alcançar a idealização que a cultura produzirá.

Estas relações complexas do modo como a cultura e seus valores ajudam na capacidade de tolerar, criticamente, e não acatar passivamente o ordenamento instrumental das lideranças autoritárias e suas consequências nefastas para a 
humanidade, como aquelas que foram produzidas no século passado e que, por teimosia, persistem atualmente.

\section{INTOLERÂNCIA NO BRASIL CONTRA OS AFRO-RELIGIOSOS}

O objetivo inicial da colonização dessas terras na América por Portugal foi a intenção de impor a fé católica no Brasil. Como relata Santos et. al.

\footnotetext{
Para os colonizadores, as grandes navegações para a América eram como "cruzadas". Essa era uma mentalidade já marcada pela conquista e reconquista de seu território dominado antes pelos árabes, quando, então, empreenderam "guerras santas" contra os infiéis (SANTOS et al., 2018, p. 106).
}

O catolicismo foi imposto pelos portugueses no Período Colonial (1500-1822) e essa imposição proporcionava uma obediência à Coroa Portuguesa e, ao mesmo tempo, a fé católica na América Portuguesa. A aliança da Coroa Portuguesa com a Igreja Católica consistia na adoção Padroado, que significava uma autorização da Igreja Católica ao Estado lusitano; em contrapartida, a Coroa fomentaria e confirmaria os direitos e a estruturação da Igreja nas possessões ultramarinas portuguesas (SANTOS et al., 2018, p. 106).

A conversão dos nativos da América portuguesa ao catolicismo ficou na incumbência dos padres jesuítas que, ao catequizá-los, evitariam as contendas entre os colonos e os nativos pela posse da terra.

A Igreja e seus representantes na Colônia, os padres jesuítas, convertiam os nativos e colocavam-nos para trabalhar forçadamente em terras que a Ordem dos Jesuítas acumulava e lucrava, com o aval da Coroa Portuguesa, o que provocou conflitos entre os colonos e os padres, que estavam contra a escravização dos nativos pelos colonos e os utilizavam como mão de obra em seus empreendimentos. 
A conversão dos indígenas foi um fator de apoio para a Coroa Portuguesa contra os invasores, como no caso da tentativa dos huguenotes franceses e da formação da França Antártica, no Rio de Janeiro, em 1555 (SANTOS et al., 2018, p. 107) e da invasão do Nordeste pelos holandeses, primeiro na Bahia, em 1624, que sofreu resistência daqueles que fugiram de Salvador, com emboscadas sobre os holandeses e o envio de tropas espanholas.

A Espanha, na época, era inimiga dos holandeses e havia controlado Portugal devido à União Ibérica - que teve início em 1580 e foi encerrada em 1640, na Restauração Lusitana. Já na invasão holandesa em Pernambuco, os holandeses dominaram boa parte do Nordeste e ficaram na região de 1630 até 1654, quando foram expulsos.

No Brasil holandês, os governantes flamengos, devido à sua religião reformada, foram tolerantes com os senhores de engenho, maioria católica, e permitiram aos judeus a construção de uma sinagoga - a primeira das Américas, cujo nome era Kahal Zur. No entanto, a retomada dos portugueses de suas possessões na América permitiu a perseguição aos judeus, que fugiram para a América Central e do Norte (SANTOS et al. 2018, p. 108).

A Igreja controlava a religiosidade de colonos, de nativos e dos escravizados africanos, que passaram a configurar como mão de obra forçada em um sistema que visava o lucro através do trabalho daqueles seres transportados para a realidade hostil e desumana da produção açucareira do Nordeste brasileiro.

Aos escravizados que não podiam cultuar seus ancestrais e deuses africanos, restava a simulação de sua religiosidade com a adoração dos santos católicos, isto é, o sincretismo religioso, que, de uma forma ou outra, ajudou na preservação da cultura trazida do continente africano, mesclando-a com a religiosidade católica, 
formando o embrião do que seria a religiosidade afro-brasileira (SANTOS et al. 2018, p. 109).

Devido aos atritos entre colonos e jesuítas gerados pela escravização de indígenas catequizados, pelos gastos com a Restauração portuguesa e pela expulsão dos holandeses, bem como pela consequente concorrência antilhana holandesa do açúcar, fatalmente, levou a Coroa portuguesa ao confisco dos bens dos jesuítas na decisiva expulsão da Companhia de Jesus da América portuguesa, em 1759.

No Período Imperial, a Igreja Católica terá um status de religião oficial do Estado Imperial, implementado e imposto pela Constituição de 1824, outorgada pelo Imperador Pedro I. A Lei permitia as outras religiões, desde que não fossem exteriorizadas em templos e reduzidas ao espaço doméstico (SANTOS et al. 2018, p. 110). Dessa forma, fica caracterizada a falta de liberdade religiosa no Brasil. Isso provocou o embate da Maçonaria ao exclusivismo Católico e pelas liberdades.

A Igreja Católica defendia o Império brasileiro devido à questão do padroado, mas, devido a questões internas da Igreja que passaram a incomodar o imperador Pedro II, os atritos entre a Igreja levaram à questão religiosa do Segundo Reinado e da crise da Monarquia brasileira, um dos fatores que levaram a ascensão dos republicanos ao poder, em 1889.

A implantação da República no Brasil vai trazer a separação entre Igreja e Estado, com a Constituição de 1891. A questão da laicidade foi colocada como principal fator de impulsionamento de uma diversidade religiosa (SANTOS et al. 2018, p. 111), no entanto, a questão da higienização e do branqueamento não permitiram uma aceitação das religiões de comunidades tradicionais de terreiro e muito menos das características culturais desenvolvidas pelo negro no Brasil. 
Devemos ressaltar a importância dada pelo novo regime republicano ao Código Penal em 1890, um ano antes da nova ordem constitucional.

A intolerância religiosa era escancarada na legislação do início da República, exemplo disso é a imposição de um padrão eugênico e Europeu na questão de crimes como crime de capoeiragem (art. 402); crime de curandeirismo (art. 158) e crime de espiritismo (art. 157). Contudo, a Constituição de 1891 e todas as subsequentes mantiveram a questão da liberdade religiosa com ressalvas, como a manutenção da ordem pública e dos bons costumes (SILVA JR., 2015, p. 309).

O episódio conhecido como "Quebra de Xangô", segundo Almeida e Silveira, teria ocorrido no dia $1^{\circ}$ de fevereiro de 1912 , na cidade de Maceió, capital do Estado de Alagoas, e seria uma demonstração de que a República foi iniciada sob o signo da repressão às religiões a afro-brasileiras e defendia o Estado laico apenas para demonstrar modernidade legal, e, na verdade, mantinha a continuidade da violência contra o negro (resquícios do pós-abolição), confirmando a política de embranquecimento da nação, da predileção do cristianismo como religião e a aversão a tudo que lembrasse o passado escravista e as origens africanas, principalmente as religiões de comunidades tradicionais de terreiro.

O grupo responsável pelas ações intolerantes contra os terreiros de Maceió na "Quebra de Xangô" foi a milícia chamada de Liga dos Republicanos Combatentes, que atuava na oposição ao Governador alagoano Euclides Malta. Esse governador estava no poder há muitos anos e, com a ajuda do principal partido de oposição, os democratas, os milicianos aproveitaram a insatisfação com o Governo para atacar os terreiros da capital (ALMEIDA; SILVEIRA, 2020, p. 129).

A tensão em Alagoas era cada vez mais intensa, o Governador passou a ser alvos de críticas cada vez mais intensas realizadas pela oposição, pela imprensa e 
pelos católicos. As principais reivindicações dos opositores eram: retirar dos negros as atividades das curas (prática ilegal da medicina), repressão à violência dos negros e a retirada do monopólio do comércio pelos negros. Resumindo, atacar as Casas de Xangô e propiciar seu banimento por apoiarem o Governo, dar poderes ao governador e serem os responsáveis pelas mazelas (feitiçarias) no Estado, de acordo com os opositores. No ataque aos terreiros, o principal alvo dos milicianos era o terreiro de Tia Marcelina, por ter sido a fundadora do candomblé em Maceió (ALMEIDA; SILVEIRA, 2020, p. 131).

A violência sofrida por Tia Marcelina foi devido a esse triste episódio da História da Intolerância Religiosa no Brasil. Contudo, o falecimento da religiosa não foi o fim das religiões afro-brasileiras nesse Estado: mudanças ocorreram, dada a continuidade da repressão da polícia alagoana diante das religiões de matriz africana. O termo "candomblé em silêncio" foi elaborado por Gonçalves Fernandes (1941), demonstrando o surgimento de uma nova expressão religiosa, devido aos riscos das batidas policiais. Mas Almeida e Silveira demonstram que esse silêncio não impediu um ressurgimento (ALMEIDA; SILVEIRA, 2020, p. 132)

Se durante quarenta anos pouco se ouviam os atabaques, hoje, o tambor é ouvido nos quatro cantos do estado; e Marcelina faz parte desse barulho. Sua memória queima, cada vez mais se intensifica. Duvidar da sua existência ou desacreditar na potência que sua imagem criou parece-nos deixar de lado o principal fio que tece o violento episódio que levou dezenas de pais e mães de santos a abandonarem suas casas e migrarem para outras cidades (Bastide, 1960).

O apagamento não ocorreu, ele foi tentado no ano de 1912, naquele triste episódio. Os autores atestam que sua lembrança ocorre todo dia $1^{\circ}$ de fevereiro, quando os terreiros se manifestam e saem em carreata pelo centro de Maceió, celebrando o movimento de resistência ao Quebra de Xangô (ALMEIDA; SILVEIRA, 2020, p.134) 
A imagem de Tia Marcelina, de acordo com Almeida e Silveira, precisava ser revisitada e enaltecida, como nos relatos

\begin{abstract}
Segundo Duarte (1974, p.12), tia Marcelina, africana pura "negra da costa" (expressão popular), gozava de enorme respeito e estima. "Era em Maceió uma espécie de Menininha do Gantois na Bahia". Fora contemplada com a coroa de Dada, irmão mais moço de Xangô, na liturgia africana; da África proviera a distinção que a sagrara. Seu terreiro era o mais antigo de Maceió, fundado ainda no século XIX. Situava-se na rua da Aroeira, na conhecida, atualmente, praça Sinimbu (ALMEIDA; SILVEIRA, 2020, p.135).
\end{abstract}

A imprensa, na época do Quebra, ao contrário, não apresentava uma imagem positiva da líder religiosa, de acordo com os autores. O Jornal de Alagoas, em seu artigo do dia 8 de fevereiro de 1912, intitulado Bruxaria, ligava a figura do exgovernador aos terreiros. Neste caso, estamos diante de um dos setores que apoiavam o Quebra, na época em questão, a imprensa.

De acordo com Almeida e Silveira, a religiosa sofrerá o maior dano à sua imagem, ou seja, "É sob os rótulos de bruxa, feiticeira e megera que o periódico Jornal de Alagoas perpetua a imagem de Marcelina" (ALMEIDA; SILVEIRA, 2020, p.136). Para os autores, a imagem de Marcelina resistiu e foi colocada a partir de informações da memória registrada fora do tempo e que passam a fazer parte desta trama que surgiu após o "Quebra de Xangô" (ALMEIDA; SILVEIRA, 2020, p.138).

Ao concluir, Almeida e Silveira enaltecem a importância do resgate da memória e da imagem de Tia Marcelina e de sua força como mulher, negra e liderança religiosa

\begin{abstract}
Nesse emaranhado, a memória de Marcelina assume um lugar de extrema importância, ao ser responsável pela continuidade da história e do legado africano em terras caetés e, de forma paradoxal, desmistifica o que outrora negaram e deturparam, sua imagem e existência. Marcelina é um emblema necessário para Alagoas. Precisa ser vista na história desse estado. Precisa ser enaltecida, e não folclorizada (ALMEIDA; SILVEIRA, 2020, p.143).
\end{abstract}

Dessa questão da manutenção da ordem pública e da não aplicação de golpes nos cidadãos ou mesmo o uso de artifícios para simular cura de doenças, o 
legislador, mesmo posteriormente, em 1940, utilizava, no Código Penal, das infrações de charlatanismo (art. 283) e curandeirismo (art. 284) (SILVA JR., 2015, p. 309). Isso foi demonstrado através de pesquisas de Ana Lucia Pastore Schirtzmeyer (1997), que dá ênfase, ao verificar os delitos de charlatanismo e curandeirismo, aos praticantes das religiões de matriz africana, geralmente associadas ao primitivismo e ao barbarismo.

O direito estadual, no Estado da Bahia, obrigou as casas de religiões afrobrasileiras a obterem o registro na Delegacia de Polícia da região. Já na Paraíba, uma lei de 1966 condicionava o funcionamento dos "cultos africanos" à permissão dos Órgãos de Segurança Pública e, o que mais constrange, à apresentação de exame provando a saúde mental do responsável pela casa, isto é, um laudo psiquiátrico (SILVA JR., 2015, p. 309).

A liberdade religiosa no Brasil não foi considerada e respeitada quando se tratava de religiões de matriz africana. A perseguição ou mesmo a desqualificação perante as leis fica marcada como uma forma de desqualificação da cultura e dos saberes afro-brasileiros e a sua comparação com algo maligno ou criminoso, caracterizado pelos legisladores e pela imprensa. O branqueamento e o tratamento das religiosidades no Brasil, na forma de demonização ou enganação, estavam caracterizados pelos textos legais e pela higienização da população, através de tratamento ligados à medicina estabelecida pelos órgãos de Saúde do Governo. A cura alternativa sempre foi encarada e taxada como uso ilegal da medicina, curandeirismo e charlatanismo.

A Constituição de 1891, tendo por princípio a laicidade, ampliou a liberdade religiosa. O financiamento público de atividades religiosas estava vedado e inovou 
com a introdução a objeção de consciência ${ }^{20}$ (art. 72 , § 29, primeira parte), o objetor, no caso, condicionava-se a perder os direitos políticos à época.

$\mathrm{Na}$ Constituição de 1934 foi colocada a previsão de assistência religiosa nas instalações militares, hospitais e penitenciárias, sem tributos ou despesas para o Governo. Além disso, previu-se a existência de cemitérios particulares mantidos por assembleias religiosas, a validade do casamento religioso com efeito do casamento civil e a adoção do ensino religioso com presença facultativa (SILVA JR., 2015, p. 311).

Na Carta de 1937, a mudança foi na questão do ensino religioso, que era facultativo. Na Constituição de 1946, foi feita a introdução da imunidade tributária do templo e o aperfeiçoamento da objeção de consciência, propondo que fosse vedada a perda de quaisquer direitos, desde que o agente cumprisse prestação alternativa, de acordo com a lei. Na Carta de 1967, foi acrescentado o princípio de igualdade à vedação de distinção em razão do credo religioso.

A Constituição de 1969 excluiu a obrigatoriedade da assistência religiosa nas forças armadas. Como as anteriores, esta carta condicionava a liberdade religiosa e a expressão religiosa à preservação da ordem pública e à questão dos bons costumes, o que foi vedado na Constituição de 1988 (SILVA JR., 2015, p. 312).

O Estado laico e a vedação de alianças - ou relação de dependência com qualquer religião em detrimento de outras - são conquistas da atual Constituição de 1988. No famoso art. $5^{\circ}$, dos direitos e garantias fundamentais, no inciso $\mathrm{VI}$, é

20 A Constituiç̃̃o Federal de 1988 assegura a objeção de consciência, como decorrência do previsto em seu artigo $\underline{\underline{5}^{\circ}}$, inciso $\underline{\text { VI, }}$ onde se lê que "é inviolável a liberdade de consciência"(...) Além disso, a CF dispõe em seu artigo $\underline{5^{\circ}}$, inciso VIII que é vedada a privação de direitos em decorrência de crenças pessoais (religiosas, científicas ou filosóficas). Na hipótese de eventual recusa à realização de obrigação legal genérica, por objeção de consciência, é possível ao Estado cominar obrigação alternativa (por meio de lei). Apenas se a pessoa recusar essa obrigação alternativa é que poderia ocorrer qualquer punição. Uma das situações em que esse direito é expressamente previsto diz respeito à obrigatoriedade do serviço militar (artigo 143, $\S 1^{\circ}, \mathrm{CF}$ ). Consulta em 05 de maio de 2020. Disponível em: <https://joaorodrigostinghen.jusbrasil.com.br/artigos/661583853/o-direito-aobjecao-de-consciencia> 
apresentada a liberdade de crença, a liberdade religiosa, liberdade de liturgias e de organização religiosa. No inciso VIII, é vedada a privação de direitos devido ao credo religioso e são estabelecidas regras no plano infraconstitucional

\begin{abstract}
O Código Penal, que pune o ultraje a culto e impedimento ou perturbação de ato a ele relativo (art. 208). O Código de Processo Penal, que inscreve o ministro religioso no elenco das pessoas às quais é deferido o direito à prisão especial (art. 295). A lei 4898/65, que pune o abuso de autoridade decorrente de atentado à liberdade de associação, à liberdade de consciência e de crença e ao livre exercício do culto religioso (art. $4^{\circ}$ alíneas "d" e "e"). A lei n $n^{\circ} 7716 / 89$, que pune a prática, a incitação e a indução à discriminação ou ao preconceito por motivo de religião entre outros (art. 20). A lei 8212/91, que equipara, para fins previdenciários, o ministro religioso aos trabalhadores autônomos (art. 12, inciso V, alínea "c") (SILVA JR., 2015, p. 313/314).
\end{abstract}

O art. 19 deixa clara a organização estatal não atrelada a expressões religiosas ou a igrejas, não devendo haver ligação ou aliança, ressalvado o interesse público. Temos o art. 150, que trata da tributação e sua vedação por todos os entes da federação, que deixa claro, no seu inciso VI, impostos sobre templos de qualquer religião. Já o art. 226 dispõe sobre o "Casamento Religioso", ou seja, o casamento religioso passou a ter efeito civil (SANTOS et al., 2018, p. 113).

As mudanças no campo religioso brasileiro permitiram o surgimento de novos algozes e perseguidores mais eficazes do que a Igreja Católica e o Estado. O surgimento dos grupos neopentecostais e a sua expansão tem provocado, como eles mesmos usam o termo, uma "batalha espiritual" contra as forças do mal, isto é, o diabo e os seus representantes na Terra. O problema de enfrentar o mal, neste caso, não é apenas falar mal, humilhar o diabo e seus seguidores em seus templos. A luta deles vai a qualquer lugar da sociedade e acaba provocando agressões, xingamentos e hostilidades contra o que os neopentecostais afirmam ser os seguidores do diabo - principalmente, os seguidores das religiões de matriz africana no Brasil. 
O surgimento desses grupos neopentecostais radicais remonta à formação da Igreja Nova Vida do MacAlister. A polêmica da "batalha espiritual" demonstra a belicosidade e a falta de uma possibilidade de abertura ao entendimento e à construção de um ambiente de conivência tolerante e respeitosa. Ao que ainda demonstra Reinhardt

\begin{abstract}
A tendência desse grupo a alimentar um ambiente inter-religioso tenso e exclusivista, atitude rotulada por diversos setores da opinião pública brasileira como "intolerante", pode ser entendida se atentarmos ao terceiro dos aspectos antes destacados: a função gramatical ocupada pelo mal em sua cosmologia, em que se assentaria a noção de "batalha espiritual (REINHARDT, 2007, 30 e 31).
\end{abstract}

A "batalha espiritual" pode ser definida como uma metanarrativa construída através da bricolagem de elementos clássicos da narrativa bíblica, como o maniqueísmo, a existência do diabo e das suas hordas e dos modos de explicação de infortúnios tidos como "arcaicos", como a feitiçaria, a possessão e a transferência do mal através do contato ${ }^{21}$. Unidos numa espécie de "drama bélico", esses elementos textuais teriam a finalidade de encenar metonimicamente a subjetividade e o cotidiano dos fiéis neopentecostais como um perene campo de batalhas entre forças "do bem" e "do mal".

Porém, ao analisarmos as razões para os ataques sofridos pelos afroreligiosos, é a "demonização" de seus atos o motivo pelo qual atuam os intolerantes. Ao argumentarem suas razões para agirem dessa maneira, notamos suas características específicas que alimentam as ações intolerantes, como assinala Santos et. al

\footnotetext{
$21 \quad$ Mariano (1999) aponta que o verdadeiro demiurgo da batalha espiritual no Brasil seria o missionário canadense Walter Robert McAlister, fundador da Igreja Pentecostal de Nova Vida, nos anos 1960. Tal fato pode ser confirmado pela evidente aproximação entre as ideias e práticas defendidas pela IURD e o livro "Mãe de Santo", de McAlister, como destaca Silva (2007). Não por acaso os dois grandes líderes do movimento neopentecostal, Edir Macedo e Roberto Romildo Soares, da Igreja Internacional da Graça de Deus, são dissidentes na Nova Vida.
} 
De acordo com Mariano (1999), as principais características do neopentecostalismo são: i) a influência da "teologia da prosperidade", que potencializa as dimensões econômicas não-ascéticas do cristianismo pela ênfase na realização cotidiana de milagres tendo em vista "uma vida abundante";22 ii) a liberalização dos "usos e costumes", que desmonta o controle estrito do comportamento, que antes distinguia os pentecostais clássicos como um grupo "à parte" ante a sociedade envolvente (fato geralmente ratificado pela aparência pessoal, pela moralização da esfera sexual e pelas restrições de lazer desses indivíduos); e iii) o papel central ocupado em sua cosmologia pelas entidades demoníacas, de onde resulta o frequente recurso ritual ao exorcismo e os intensos conflitos com as religiões mediúnicas, principalmente as afro-brasileiras, como o candomblé, a umbanda e a quimbanda (SANTOS et al., 2018, p. 30).

Ao verificarmos que a questão da imposição de uma religiosidade através da força tem levado aos diversos conflitos por questões e motivações religiosas, observamos que aqui no Brasil não é diferente, mas a desculpa dos neopentecostais sobre suas atitudes é simplesmente disputa por mercado religioso. Daí, devemos indagar: que disputa é essa que leva a agressões, torturas, destruição do objeto sagrado e conflitos territoriais constantes?

A estratégia dessas religiões, principalmente a IURD, é a de ressaltar a negatividade das religiões afro-brasileiras. O resultado é um maniqueísmo, uma ação de discurso contra a ética do protestantismo histórico e do Deus mudo, ao contrário, eles reforçam um constante contato com o mundo sobrenatural, demonstrando as curas e as expulsões do demônio ou, melhor dito, dos encostos.

A contenção dos conflitos, atribuição do Estado, tem sido deslocada para uma questão de organização dos afro-religiosos por demandas na Justiça contra os atos intolerantes. Em alguns casos, utilizam-se dos meios legais justificando-se, principalmente, como citado por Santos et al.

\footnotetext{
22 Apesar da origem norte-americana da "teologia da prosperidade", veremos, ao longo do primeiro capítulo, como a IURD (Igreja Universal do Reino de Deus) insere em sua aplicação ritual a contraparte de uma lógica de reciprocidade em que o dízimo dos fiéis passa a ocupar a função de meio intra-religioso dinamizador das trocas com o polo sobrenatural, viabilizando-se assim uma troca sacrificial mediada pelo dinheiro.
} 
i) o artigo $5^{\circ}$ da Constituição Federal 1988, em seu parágrafo Vl: "é inviolável a liberdade de consciência e de crença, sendo assegurado o livre exercício dos cultos religiosos e garantida, na forma da lei, a proteção aos locais de culto e suas liturgias"; ii) a Lei $7716 / 89$, de combate ao racismo modificada em maio de 97 de modo a incluir a "intolerância religiosa" como prática discriminatória em seu artigo primeiro: "Serão punidos, na forma desta Lei, os crimes resultantes de discriminação ou preconceito de raça, cor, etnia, religião ou procedência nacional"; 23 além iii) do Artigo 275, da Constituição Estadual, que define que é dever do Estado "preservar e garantir a integridade, a respeitabilidade e a permanência dos valores da religião afro-brasileira". A partir do sucesso desses contra-ataques via poder judiciário, observa-se a visível rotinização de uma abordagem jurídica da realidade por parte das comunidades de terreiro de Salvador (SANTOS et al., 2018, p.152/153).

A disputa, na cidade de Salvador, no Estado da Bahia, provocou uma reação por parte dos afro-religiosos, que passaram a utilizar-se de processos e da atuação do Ministério Público do Estado, que reforçou a defesa do povo de santo com a criação de um departamento específico para casos de intolerância religiosa. Esse órgão tem atuado no interior da $2^{\mathrm{a}}$ Promotoria de Justiça e da Cidadania e foi criado no ano de 1997.

Quando observamos os casos que ocorreram no passado e os mais recentes, eles têm em comum uma questão pertinente aos estudos aos quais estamos propondo: inicialmente, entender as razões para a demonização das religiões afrobrasileiras e de seus seguidores e até mesmo frequentadores.

Utilizando dos estudos de Bento, foi verificado que a questão da "exclusão moral pode assumir formas severas, como genocídio; ou mais brandas, como a discriminação". Para Bento, guardamos solidariedade e empatia com família e amigos, quanto aos inimigos e grupos estereotipados negativamente, não temos os mesmos sentimentos. Pelos mecanismos da exclusão social, os excluídos de nosso grupo devem ser condenados com dureza e as falhas cometidas por esses grupos permitem o tratamento desumano e degradante (BENTO, 2002, p. 30).

\footnotetext{
23 O texto original era: "Serão punidos, na forma desta Lei, os crimes resultantes de discriminação ou preconceito de raça ou de cor".
} 
Bento cita Said e sua obra Orientalismo: Oriente como invenção do Ocidente (1990) ao analisar a europeização e o olhar do europeu sobre aqueles que não são, ou seja, a identidade do homem europeu tornou-se universal e invejada pelos nãoeuropeus, sempre considerado o "outro". Ao colocar-se como modelo de humanidade e projetar sobre o outro o que não se quer assumir, desenvolvemos um modelo narcísico e projetamos sobre os outros nossos medos, principalmente o medo do diferente (BENTO, 2002, p. 31).

O medo do negro no Brasil é histórico, como aponta o estudo de Célia Marinho de Azevedo em sua obra Onda negra, medo branco (1987), que considera o nascimento do ideal de branqueamento do medo da elite branca da maioria negra no final do século XIX e início do século XX, daí a solução do branqueamento via imigração europeia. Enfim, o medo do negro, como demonstra Azevedo, pode ser considerado como medo da sua cultura e de sua religiosidade, obviamente, o que não pode ser descartado (BENTO, 2002, p. 32).

O medo foi trabalhado por Jean Delumeau (1989) em sua história do medo no ocidente, principalmente o medo das elites em relação aos despossuídos. O medo gerado pelo negro não deve ser descartado, se considerarmos o medo da elite branca brasileira e de suas teorias importadas da Europa - divulgadas pela elite, através de sua imprensa, e atacada pelos poderes repressivos usados pelos detentores do poder como higienização da sociedade e do cotidiano no Brasil (BENTO, 2002, p. 33).

Ao perseguir o outro satanizado, na forma diferente dos negros e indígenas no ultramar, focalizava-se a destruição do mal, que, no Velho Continente, também tinha os seus elementos que seriam perseguidos e eliminados. Quando necessário, as mulheres eram satanizadas e perseguidas através da caça às bruxas, os 
mendigos sofriam perseguições legalizadas e autorizadas através de estatutos que impediam a mendicância no campo e nas cidades (BENTO, 2002, p. 34).

A coletividade insuflada por uma elite maniqueísta e preconceituosa justificara injustiças aos criminosos e aos que, geralmente, têm transferido todo o ódio e raiva contra si. Tal sentimento, muitas vezes, é escondido por essas mesmas elites da sociedade como um todo, encontrando bodes expiatórios para suas próprias atitudes condenáveis e absurdas, que, fatalmente, levam a ascensão do fascismo e do nazismo - como ocorreram e ocorrem nas manifestações baseadas no ódio, na intolerância e levadas a cabo pelas violências e os genocídios praticados.

O medo e a projeção forçam a estigmatização de grupos e a perpetuação das desigualdades, até o extremo do genocídio. Ao tratarmos das religiões afrobrasileiras, percebemos a questão do medo e da perseguição destes como uma legitima defesa dos escolhidos de Deus contra as forças do mal e seus representantes (BENTO, 2002, p. 35).

A imigração europeia, devido ao terror que a elite depositava nos remanescentes dos negros após a abolição, excluía o povo negro e, como solução para o problema, investia em sistema carcerário e prisão psiquiátrica.

Esse período higienista confinava mulheres negras no asilo Juquery, como registrado no livro O espelho do mundo - Juquery, a história de um asilo, de Maria Clementina Pereira Cunha. A criação deste asilo foi próxima ao período abolicionista.

Nesse período, a psiquiatria brasileira funcionava como uma ferramenta da política higienista, racista e embranquecedora do regime republicano que se apoiava na antropologia criminal de Lambroso, psiquiatra italiano que defendia a questão das proporções do corpo como espelho da alma. 
Para enfatizar sua teoria racista, Lambroso elege o negro como o criminoso nato, daí a ideia de encarcerar para evitar o aumento de crimes (BENTO, 2002, p. 3).

A psiquiatria, ao colocar hospitais no Brasil, no início da República, visava a exclusão, o confinamento e o extermínio dos indesejáveis para a sociedade. 0 pesquisador Patto (1997) aponta que a Liga Brasileira de Higiene Mental, formada por psiquiatras do Rio de Janeiro, era favorável à esterilização dos desajustados, isto é, negros alcoólatras, tuberculosos, sifilíticos, loucos e infratores. A intenção desses profissionais de saúde era inviabilizar o crescimento da população negra no Brasil. Já os políticos, no afã de embranquecer a população brasileira, incentivava a imigração massiva de europeus e, com a miscigenação e assimilação, desapareceria o negro e, efetivamente, a cultura e religiosidade dos negros no Brasil.

Citando Schwarcz, com sua obra O espetáculo das raças (1993) os cientistas sociais desejavam o desenvolvimento do Brasil nos moldes do modelo civilizacional dos europeus, mas o modelo de desenvolvimento do País foi proporcionado pela escravização do negro. Para solucionar este imbróglio, foi adotada a questão da transição, a assimilação do negro pelo branco e a depuração racial brasileira (BENTO, 2002, p. 37).

A assimilação tem ingredientes que, de acordo com Bento, levam ao amor canibal, que parte da premissa de incorporar ou devorar o outro, teoria elaborada por Freud. Tal teoria pode ser utilizada no entendimento dos planos da elite branca no final do século XIX no Brasil.

Ao utilizar de conceitos como ódio narcísico aos elementos de fora, Adorno e Horkheimer (1985) vislumbram a questão da paranoia, baseada nas defesas 
primordiais que signifiquem uma expulsão das ameaças à integridade egóica. A "falsa projeção", isto é, o meio pelo qual um sujeito tenta desvencilhar dos impulsos ao qual não os admite, despejando-os no outro. Enfim, ocorre a escolha da "vítima em potencial". Esse outro passa a ser demonizado.

No caso do negro brasileiro, estudiosos como Octavio lanni (1972), Fúlvia Rosemberg (1985), Ana Célia da Silva (1991), entre outros, revelam que a comunicação visual não só demoniza, estigmatiza, deprecia e desumaniza, mas também transformam o indivíduo na própria encarnação do mal: obviamente, tudo que lembre o negro brasileiro.

O que é evidenciado por nossos estudos é a transformação da religiosidade afro-brasileira na própria manifestação satânica, quando ritualizada ou lembrada; até mesmo a cor predominante nos rituais afro-brasileiros é criticada e motivo de temor ou ataques. Esse processo não ocorre agora, evidenciam-se essas atitudes depreciativas e persecutórias no passado e no presente (BENTO, 2002, p. 38).

Ao analisar Fanon, Bento (2002) focaliza nos estudos deste psicanalista negro, que trabalha a questão da projeção na elaboração do preconceito racial do branco contra o negro. A conclusão destes estudos leva à equiparação do negro, à fobia do biológico, da força, do sexo, do forte, do potente, do animal, do diabo, do pecado, do terrível, do sanguinário, entre outros. Resumindo, estas constatações de Fanon levam o negro à esfera biológica. Isso demonstra a mente do europeu com relação ao africano: um combinado de elementos marcadamente sexualizados e culpabilizados, pois ao africano a sexualidade não é marcada por proibições como aos europeus, mas sim considerada uma necessidade vital, assim como respirar, alimentar-se ou descansar. Fanon coloca o negro como um perigo biológico, ou seja, quando se trata de sexualidade, o negro domina, principalmente tratando-se de 
desvios sexuais, como a violência do estupro, isto é, estupro é especialidade do negro (BENTO, 2002, p. 39).

A projeção é um problema quando ocorre a "projeção patológica ou falsa projeção" que é "a transferência dos impulsos condenáveis do sujeito para o objeto". Já para Kaes (1997), a projeção a partir do grupo carrega uma fantasia coletiva de atacar e ser atacado. O mau está no inimigo, que poderá ser atacado ou discriminado cotidianamente (BENTO, 2002, p. 40/41). Essa ênfase na projeção do outro engloba os grupos neopentecostais - que buscam a supremacia religiosa e o outro "demonizado", humilhado e inferior, pois abraçou o mau: os fiéis das religiões afro-brasileiras.

Bento, ao abordar a questão da problemática racial brasileira, demonstra a questão das desigualdades resumida aos problemas de uma herança negra da escravização. No entanto, o silêncio sobre a interferência do branco para a manutenção da escravidão é notório, ela confirma essa questão como uma intervenção da branquitude guardando silenciosamente a manutenção dos privilégios.

Bento aponta exceções sobre os pesquisadores, como Edith Piza (1998), que é branca, brasileira e estuda a questão do branco. De acordo com Piza, os brancos, em seus discursos, mantêm distância, não tratam sobre a questão racial e não enxergam o outro. O branco só vê a si mesmo e o negro, para o primeiro, não é visível; a questão racial não é tratada pelo branco, a raça é posição hierárquica, isto é, acredita-se na supremacia racial branca e, caso um negro tenha destaque, está "querendo aparecer".

Ao perceber a dificuldade do racismo sobre os negros, Bento identificou uma pesquisadora que elencou a evolução de uma identidade racial branca não-racista, 
desde que a pessoa aceite a sua branquitude. A evolução passa por seis estágios: "contato, desintegração, reintegração, falsa independência, imersão/emersão e autonomia" (BENTO, 2002).

No estágio ou contato inicial, há uma curiosidade com as pessoas negras e, por medo de estereótipos aprendidos entre grupos de familiares, amizades ou pela mídia, evitavam contatos com pessoas negras ou abordagens sobre questões raciais.

Novos contatos e esclarecimentos sobre racismo levam ao rompimento desse estágio inicial e o início de um estágio de desintegração, ou seja, a culpa e a raiva, dada a verificação das vantagens dos brancos e da manutenção do racismo. Com o desconforto da nova situação, alguns se convencem de que racismo não existe e, se existe, é culpa do próprio negro. A vítima do racismo passa a ser culpada pela situação, é o que demonstra Munanga, em suas considerações sobre o racismo brasileiro, quando considera que "o Brasil criou seu racismo com base na negação do mesmo" (MUNANGA, 2005/2006, p. 53).

A questão, aqui, fica complexa, devido ao sistema escravista e suas vantagens e desvantagens serem peremptoriamente negadas. Munanga, em uma entrevista, definiu bem a questão do racismo no Brasil: existe racismo, sim, mas o racismo não é assumido pelo racista no Brasil

Quando a Folha de S. Paulo fez aquela pesquisa de opinião em 1995, perguntaram para muitos brasileiros se existe racismo no Brasil. Mais de $80 \%$ disseram que sim. Perguntaram para as mesmas pessoas: "você já discriminou alguém?". A maioria disse que não. Significa que há racismo, mas sem racistas. Ele está no ar... Como você vai combater isso? Muitas vezes o brasileiro chega a dizer ao negro que reage: "você que é complexado, o problema está na sua cabeça". Ele rejeita a culpa e coloca na própria vítima. Já ouviu falar de crime perfeito? Nosso racismo é um 
crime perfeito, porque a própria vítima é que é responsável pelo seu racismo, quem comentou não tem nenhum problema ${ }^{24}$.

Para Bento, "Helms (1990) sugere que é realmente fácil para os brancos ficarem paralisados no estágio de reintegração", evita-se o negro, havendo o questionamento da definição de branco e justificando-se o racismo.

A situação de incômodo das vantagens da branquitude passa a provocar o indivíduo na busca por respostas, o que conduz ao estágio de desenvolvimento imersão/emersão. Estudos sobre mudanças de brancos com relação ao racismo provocará uma internalização de uma situação nova e a busca de um estágio de autonomia, o que levará a ações de enfrentamento à opressão e ao racismo na vida cotidiana. Nesse estágio, a pessoa está aberta a informações e admite variações sobre a cultura e o racismo, culminando em atitudes antirracistas e em denúncias sobre atitudes racistas e promotoras da manutenção de uma mentalidade racista (BENTO, 2002, p. 44).

O objetivo do nosso trabalho é contribuir para a autonomia dos brancos sobre os problemas relacionados à rejeição das religiões afro-brasileiras e ao processo de demonização e ridicularização dessas. Temos em mente que nosso objetivo não é proselitismo e, muito menos, uma busca da expansão religiosa de matriz africana, o fato a se buscar nestes estudos é o desenvolvimento de uma autonomia do pensamento, configurando uma manifestação de sentimento antirracista somado a uma visão de importância histórica e cultural da religiosidade de matriz africana para a sociedade brasileira.

Analisando os pactos narcísicos, Bento cita René Kaes (1997) e o silenciamento sobre a questão racial, que poderá provocar mudanças ou gerar

\footnotetext{
24 Disponível em: $<$ https://revistaforum.com.br/revista/77/nosso-racismo-e-um-crime-perfeito/>. Acesso em 12 de mar de 2020.
} 
descontentamentos, devido, justamente, ao fato de o ocultamento do racismo e do pacto da culpabilidade das desigualdades serem do próprio negro. Tais fatos promoverem justificativas para a situação privilegiada como uma construção de um discurso de promoção por mérito e competências para o branco estabelecer-se como superior hierarquicamente. O problema da desigualdade, portanto, é deixado para o negro, que não acompanha o ritmo do branco ou mesmo tem as suas habilidades, sempre falseadas pela meritocracia e empenho deste e pela indolência ou falta de iniciativa dos negros de superarem suas problemáticas (BENTO, 2002, p. 45/46).

Bento analisa o problema do branqueamento, abordado de forma a pautar como um problema de exclusividade do negro. Sua formação tem início no temor da elite branca, no final do século XIX e início do século passado, e objetivava a extinção do negro brasileiro e, obviamente, de sua cultura e religiosidade.

Ela aponta que diversos estudiosos apontaram para a construção de uma nação miscigenada e, num processo de transição, a esperança da elite era a formação, com o tempo e através do cruzamento das raças, de um país branco. Uma imagem retrata bem essa expectativa como a pintura do quadro $A$ redenção de $\mathrm{Cam}^{25}$, na qual é retratada uma expectativa da elite, em uma imagem premiada na época, por colocar em uma tela o desejo dos gestores em suas ações para tornar o Brasil uma nação com um futuro embranquecido.

O início da colonização portuguesa carecia de mão de obra e de colonos dispostos a desbravar as novas terras que se revelavam ter dimensões imensas, em relação à metrópole portuguesa. Aos colonos portugueses, que ficaram por estas

25 A Redenção de Cam. In: ENCICLOPÉDIA Itaú Cultural de Arte e Cultura Brasileiras. São Paulo: Itaú Cultural, 2020. Disponível em: <http://enciclopedia.itaucultural.org.br/obra3281/a-redencao-de-cam>. Acesso em: 12 de Mar. 2020. Verbete da Enciclopédia. ISBN: 978-85-7979-060-7 
terras, dada a falta de mulheres brancas, foi permitido procurar mulheres indígenas e, após algum tempo, as escravizadas oriundas da África. Bento cita Gilberto Freyre (1980), em sua obra Casa grande e Senzala, na qual a miscigenação era a saída para o povoamento e colonização dos portugueses nessas terras. Ao suavizar o conflito e buscando afirmar conciliação racial, Freyre negará o preconceito racial e fornecerá à elite brasileira os argumentos para a manutenção do seu domínio, ou seja, cria-se o "Mito (ou ideologia) da Democracia Racial Brasileira", uma legitimação do racismo e uma salvaguarda das elites para propor ao Brasil o seu branqueamento como política pública.

Ao citar estudiosos como Florestan Fernandes, Octavio lanni, Fernando Henrique Cardoso, Roger Bastide, todos ligados a Universidade de São Paulo, Bento diz que eles desenvolveram estudos relacionados às relações raciais no Brasil e contestaram a ideologia da democracia racial (BENTO, 2002, p. 48).

A contribuição de Florestan Fernandes é de denúncia do racismo, da violência da escravidão e da deformação do negro, diante dos abusos do cotidiano laboral do escravizado. No entanto, o referido autor não considera as deformações que o sistema escravocrata provocou no branco, deixando-o com os campos da moral e da ética deformados, tanto pela omissão quanto pela decisão de utilizar do trabalho e do lucro proporcionado pelos escravizados. Bento considera que, ao deformar o negro, Florestan Fernandes inferiorizou-o e a elite aproveitou da riqueza produzida, não tendo essa sido apenas omissa com relação ao trabalho do escravizado, mas, também, dele tirado lucro (BENTO, 2002, p. 49).

Bento verifica que Florestan Fernandes não atribuía ao recém liberto uma condição de homem livre, o que o faz indagar se o senhor que utilizava da mão de obra escravizada tinha atributos e comportamentos de homem livre. Ainda citando 
Fernandes, Bento analisa a tentativa de branquear do negro e de participar do mundo dos brancos.

Ao citar Octavio lanni (1972), Bento demonstra o branqueamento como desejo do negro e lanni afirma: "branquear é uma aspiração universal. Negros, mulatos escuros e mulatos claros, todos querem branquear". Bento conclui que tanto Fernandes quanto lanni não abordavam sobre o branco, o problema da questão racial, portanto, estava centrado no negro, na escravidão ao qual estava submetido e nas desigualdades oriundas deste tipo de utilização de mão de obra, isentando o branco pela escolha e pelos lucros oriundos desta opção econômica para os brancos brasileiros (BENTO, 2002, p. 50/51).

A questão do branqueamento atinge a todos os nacionais, pois o branco não assume a culpa pelas vantagens que o sistema escravocrata the auferiu e o negro é manipulado pelos argumentos da sociedade branca de que a saída é a integração e ascensão sociais. Bento cita Hasenbalg (1979), “o Brasil não é um terreno fértil para o surgimento do orgulho racial, parece também não ser para o florescimento do orgulho nacional!"

Bento conclui que a ascensão do negro incomoda e que os estudos sobre branqueamento estão associados ao desejo de ascensão social ao "mundo dos brancos" (BENTO, 2002, p. 52/53).

Bento destaca que o lugar de fala de muitos pesquisadores representa o olhar masculinizado do europeu dominador, que desvalorizou o colonizado e o escravizado. Citando Montánhez (1990), ela propõe a mudança do opressor pelo oprimido, compreendendo a dominação pelo ponto de vista do dominado, "permitindo-lhe explicitar seus próprios mecanismos de defesa e ataque à dominação." 
Não dá para esconder a influência do branqueamento sobre o negro e o abatimento sobre a personalidade do negro, como afirma a pesquisadora negra Neuza Souza (1983), isto é, o negro é coagido a aceitar uma identidade branca.

Bento considera que o Movimento Negro e sua militância têm encontrado dificuldades de identificação racial, dada a baixa-estima, que dificulta a mobilização contra o racismo (BENTO, 2002, p. 54). A atuação desse movimento possibilita a denúncia de violações de direitos do povo negro e explicita o que é, na verdade, o Brasil - um país onde o racismo é tolerado, fomentado e é escancarado, quando se trata da religiosidade afro-brasileira. Mesmo se tornando religiões universais ou religião para todos, como relata Prandi (2005), não é uma tarefa fácil escancarar e denunciar o racismo, mas a formação de uma identidade e o encontro do país com sua própria história perpassa o conhecimento da contribuição das religiões de comunidades tradicionais de terreiro na construção de um campo religioso brasileiro e de uma identidade nacional.

O problema atual é o crescimento de setores mais beligerantes e decididamente mais organizados e atuantes na esfera política, proporcionando um aumento significativo de atos intolerantes contra os fiéis das religiões afro-brasileiras e das representações culturais que remetem às comunidades tradicionais de terreiro. De acordo com Oro (1996), não há uma definição nítida sobre o pentecostalismo e o seu modo de agir, que apresenta características: liderança forte, não ecumênico, liberal, cura e libertação divina, proselitismo eletrônico e organização empresarial.

Ao apontar determinadas denominações como responsáveis pelas mudanças no próprio movimento pentecostal, Mariano (2003) cita a "Universal do Reino de Deus, a Internacional da Graça de Deus, a Renascer em Cristo e a Comunidade 
Evangélica Sara Nossa Terra." As mudanças no campo neopentecostal são constantes e as dissidências produzidas por estas denominações permitem perceber que a fórmula de sucesso já foi dada, que o mercado religioso é prospero, no Brasil, e que as características comuns, grosso modo, ainda de acordo com Mariano, são

1) Pela ênfase na guerra espiritual contra o diabo e seus representantes terrenos;

2) Pela difusão da Teologia da Prosperidade;

3) E pelo abandono de grande parte dos tradicionais e estereotipados usos e costumes puritanos de santidade (MARIANO, 2003, 21).

O uso da Teologia da Prosperidade é o meio mais utilizado no proselitismo neopentecostal e modificou o quadro religioso no Brasil, causando um crescimento vertiginoso dos neopentecostais. O crescimento dos evangélicos no Brasil tem essa ligação enfática da solução para os problemas do momento, do agora, nesse instante e não para uma vida eterna. A salvação em outro plano é trocada, como afirma Mariano (2003), por uma salvação terrena. Em um mercado competitivo, os produtos religiosos dos neopentecostais procuram atrair um maior número de fiéis cansados das promessas de vida em abundância para após a morte, como afirma o autor

\footnotetext{
Pragmáticos, escolados em técnicas de marketing e livres do tradicionalismo denominacional, os líderes neopentecostais das igrejas numericamente mais bem sucedidas não titubearam em submeter sua oferta religiosa à lógica do mercado religioso. Para tanto, dedicaram-se avidamente a atender às preferencias das massas pobres, diminuindo suas exigências éticas e comportamentais, adaptando sua mensagem às demandas mágico-religiosas dos estratos populares e prometendo na menos que a panaceia. "Pare de sofrer: nós temos a solução", alardeia o lema proselitista da Igreja Universal (MARIANO, 2003, p. 23).
}

As vantagens decorridas das campanhas constantes de vitórias contra os problemas em geral e de sucesso individual; das demonstrações de conquistas no plano terreno e de um Deus que não deseja o seu sofrimento e a sua pobreza, e sim melhorias e sucesso financeiro, indicam a sua associação com os valores 
decorrentes de uma fé imediatista e terrena, uma lógica de mercado da fé, no qual o interesse é o de ser bem-sucedido nos negócios da fé e, consequentemente, alcançar conquistas materiais.

O sucesso dos neopentecostais está na captação de pessoas em situações complexas. O alvo é, no geral, o pobre e desamparado pelos planejamentos inadequados e pela ausência do Estado. Ao crescer nas periferias do Brasil e conseguir aumentar, drasticamente, sua rede de apoiadores dentro e fora dos seus respectivos templos, os neopentecostais cresceram de forma demasiada na política, contando com diversos cargos. Além disso, colocaram em prática uma lógica de Estado mínimo, para, com isso, aumentar o número de necessitados que, obviamente, lotarão suas respectivas concentrações de fé, no apelo constante da Teologia da Prosperidade - que diz que você só fica na pobreza no caso de ser aliado das forças do maligno.

O fiel neopentecostal, que fica em dia com seus pagamentos de dízimos e ofertas, de acordo com essa lógica da Teologia da Prosperidade, pode exigir de Deus prosperidade, felicidade, vida saudável, enfim, exigir ser parte da sociedade de consumidores. A lógica instrumental de fé passa a ser um grande aliado de uma sociedade perversa, individualista e materialista, como a sociedade brasileira.

Ao romper com o ascetismo e abraçar o mundo do consumo e de possibilidades, as igrejas neopentecostais buscam atrair a clientela de classe média e demonstrar a conquista do mundo pelos seus propósitos de convivência com as várias modalidades de atividades mundanas: assistir programas televisivos, comprar roupas caras e até mesmo acessórios sensuais ou produtos de embelezamento, participar de eventos diversos, dançar ao som de música gospel (música que utiliza 
de baterias, guitarras, entre outros instrumentos, para atrair o público jovem ao que ficou conhecido como movimento gospel).

Devemos esclarecer o que é o bem e o mal na visão neopentecostal, de acordo com Mariano

Para eles, o mal consiste, sobretudo, nas doenças, nos baixos salários, no
desemprego, na briga entre cônjuges, no desentendimento entre pais e
filhos, na separação amorosa, no alcoolismo, no vício, na solidão, na
depressão, enfim, nos mais distintos problemas que afetam os seres
humanos. (...) O Bem, para eles, consiste, grosso modo, na prosperidade
material, na saúde física, na felicidade pessoal e familiar, no sucesso
profissional, na vitória nos empreendimentos terrenos (MARIANO, 2003, p.
24).

A guerra espiritual é um capítulo que merece destaque, devido à importância deste pressuposto para a reafirmação da fé neopentecostal: reafirmam essa guerra na Bíblia, mas colocam o campo de batalha para a humanidade. O envolvimento dos seres humanos nesta batalha dá a dimensão de cuidados e recomendações e, principalmente, do exorcismo para derrotar o diabo dentro de seus templos e estender essa luta contra as forças das trevas fora de seus templos.

Dois dos principais líderes dos neopentecostais apontam os sinais que indicam os campos de atuação das forças do mal, senão vejamos:

Edir Macedo (2002: 64-70): "nervosismo, dores de cabeça constantes, insônia, medo, desmaios ou ataques, desejo de suicídio, doenças cujas causas os médicos não descobrem, visões de vultos ou audição de vozes, vícios e depressão". A ação do diabo para as lideranças neopentecostais é sem limites.

Para R. R. Soares, da Internacional da Graça de Deus, "não existe nada que esteja fora da ação demoníaca. No futebol, na política, nas artes e na religião, nada escapa do cerco do diabo" (SOARES, 1984, p. 24). "Satanás tem milhares de agências no mundo" (Soares, 1984, p. 83). "Por trás da religião, do intelectualismo, 
da poesia, da arte, da música, da psicologia, do entendimento humano e de tudo com o que temos contato, Satanás se esconde" (Soares, 1984, p. 103). "O diabo controla tudo", resume Soares (SOARES, 1984, p. 114).

O resultado da ação dos demônios são "todos os males da humanidade", entre eles "doenças, misérias, desastres e todos os problemas" (MACEDO, $2002 / 2003$, p. 20; 25/26). Na ação de Macedo contra os demônios deve ser a "pregação plena". E, ainda, diz

A igreja atual tem que agir. Temos de sair da mera pregação pentecostal, que está na moda, para a pregação plena. Temos que sair por aí dizendo que Jesus Cristo salva, batiza com o Espírito Santo, mas também, e antes de tudo, que liberta as pessoas que estão oprimidas pelo diabo e seus anjos (MACEDO, 2002, p. 20).

O trabalho da Universal, para Macedo, é o de demonstrar poder contra Satanás e seus servidores do mal. No entanto, os adoradores do diabo têm as suas organizações religiosas sendo, segundo os neopentecostais, as religiões afrobrasileiras e kardecista os "principais canais de atuação dos demônios" (MACEDO, 2002, p. 102). Macedo não esconde sua preocupação ao exagerar no tamanho dos seguidores de Satanás, calculando que mais de um terço da população brasileira seja espírita e, com isso, vítimas das "garras" do enganador (MACEDO, 2002, p. 71).

Ludibriado pelas forças do mal que atuam na umbanda, na quimbanda, no candomblé, no kardecismo entre outras religiões, o "povo brasileiro", de acordo com Macedo, está limitado e tem barreiras para a nação se tornar um "país bem mais desenvolvido" (MACEDO, 2002, p. 62).

De acordo com Mariano (2003), "Soares e Macedo, investem pesadamente na demonização dos adversários religiosos". O que Soares declara sobre o candomblé é confirmatório sobre as questões da exposição do grupo a ser aviltado e escolhido como aqueles a serem perseguidos e ridicularizados, isto é, para ele o 
candomblé "é uma das religiões mais diabólicas que a humanidade já conheceu" (SOARES, 1984, p. 34). Já na umbanda, "os demônios são até adorados como deuses", revolta-se (SOARES, 1984, p. 70) e finaliza "O espiritismo é a maior agência que satanás estabeleceu neste mundo para extraviar e perder os homens" (SOARES, 1984, p. 84).

No mesmo embalo, Edir Macedo vê as religiões espíritas, afro-brasileiras e orientais como lugares de perdição que promovem "estupidez, ignorância e idolatria" (MACEDO, 2002). E, ainda para Macedo, tais religiões são verdadeiras fábricas de loucos e agências nas quais se tira o passaporte para a morte e se faz uma viagem rumo ao inferno (MACEDO, 2002, p. 75).

Como resultado desse ponto de vista, acredita-se que "os demônios se apossam das pessoas", dada a participação direta ou indireta em centros espíritas, por hereditariedade, pelos trabalhos ou despachos, por envolvimento com praticantes do espiritismo, pela ingestão de comidas sacrificadas a ídolos (MACEDO, 2002. p. 36/43). As crenças, principalmente das igrejas "Universal do Reino de Deus e Internacional da Graça de Deus, é de combate incessante contra os cultos afro-brasileiros, aos exus, guias, preto-velhos, encostos e orixás". (MARIANO, 2003, 27)

A aceitação dessa estratégia de combate foi corroborada pelo medo do feitiço e da magia negra, reforçando certos temores da população brasileira sobre o "baixo espiritismo", tão reforçado pelo passado das práticas afro-brasileiras e por outros atores que agora só aguardavam essa guerra ocorrer para aparecerem também como algozes das religiões afro-brasileiras.

$\mathrm{Na}$ atualidade, o reacionarismo tem somado esforços para destruir os poucos canais de diálogo inter-religioso que restam na sociedade brasileira, culpando-os 
pelo atraso da nação e abraçando uma imposição dos atuais mandatários e de lideranças conservadoras cristãs de impor um cristianismo, de declarar-se cristão como maioria e, como maioria, de impor sua vontade sobre as minorias ${ }^{26}$.

O discurso de combate ao mundo das trevas, já que o inimigo é visível e é atuante na sociedade, passa a ser a lógica beligerante aos demônios e seus seguidores. Como afirma Macedo, "os cristãos é que devem perseguir os demônios. Nossa luta é muito mais de combate do que de defesa (...) A igreja deve ser triunfante e estar sempre na ofensiva" (MACEDO, s/d, p. 114).

Mariano (2003) constata que dessa ofensividade resultará, no Brasil, um aumento das hostilidades dos neopentecostais às religiões afro-brasileiras, principalmente a partir da segunda metade dos anos oitenta do século passado. No processo de ataques à iniciativa e ao engajamento eficaz na luta contra o diabo, teve uma maior participação a Igreja Universal do Reino de Deus. As ações fora dos templos foram marcadas por invasões de centros e terreiros, de imposições forçadas da Bíblia, agressões físicas aos praticantes das religiões afro-brasileiras e espíritas e, também, atos extremos como cárcere privado.

A estratégia das igrejas pentecostais sempre se deu através da esfera discursiva, identificavam as religiões afro-brasileiras como aliadas das trevas, mas não partiam para ataques diretos. Quando se adentra o cenário religioso nacional, o "neopentecostalismo macumbeiro", como afirma Oro (2006), da Igreja Universal, liderada por um ex-umbandista, como afirma Mariano (2003), o jogo passa a ser outro. A razão da hostilidade encontra-se logo no prefácio da obra, que divulgou a declaração de guerra, no que já configura o título da obra Orixás, Caboclos e Guias:

\footnotetext{
26 Disponível em: <https://extra.globo.com/noticias/rio/grupo-conservador-tenta-impedir-missa-afro-emigreja-catolica-na-zona-sul-do-rio-24091011.html>

https://jamilchade.blogosfera.uol.com.br/2019/08/29/igrejas-denunciam-uso-do-fundamentalismocristao-pelo-governo/>. Acesso em 14 de mar de 2020.
} 
Deuses ou Demônios? Macedo vendeu milhões de exemplares da obra e revela a sua dedicação "toda a sua vida a lutar contra os demônios, por quem tem repugnância, raiva" (MACEDO, 2002, p. 7). Para moderar sua raiva, ele tratou de soltar uma demonstração de que é com violência que se combate o diabo, não é uma mera disputa por mercado da fé, ou seja, "uma verdadeira guerra santa contra toda obra do diabo" (MACEDO, 2002, p. 8).

Mariano (2003) faz um destaque do termo que está provocando muitas vítimas nessa guerra, mas cabe destacar que esse termo foi retirado por Macedo e seus seguidores por inquéritos policiais e processos judiciais movidos pelos fiéis das religiões afro-brasileiras.

Mariano observa dois objetivos dessa guerra santa dos neopentecostais contra as religiões afro-brasileiras. A primeira, o proselitismo, isto é, converter os adeptos das religiões de comunidades tradicionais de terreiro para demonstrar poder espiritual. A segunda é "fechar centros espíritas, tendas de umbanda e terreiros de candomblé, sobretudo os existentes nas proximidades dos templos evangélicos" (MARIANO, 2003). O que parece ser uma disputa de mercado religioso é uma demonstração de beligerância e de se dedicar à dizimação da concorrência nos estratos populares. É uma demonstração de força e imposição do poder de Cristo sobre o diabo e da ostensividade do seu grupo religioso sobre os concorrentes.

Nos programas religiosos, fica patenteado essa exibição de poder no ritual de exorcismo, principalmente durante a programação de rádio e TV dos neopentecostais. Dramatização de casos, disputas entre as forças do bem e do mal e a eficácia do poder divino sendo exibida a todos os que desejam acompanhar essas divulgações. Como confirma Macedo, "Em nossas reuniões, os demônios são 
humilhados e até mesmo achincalhados, numa prova de que o Senhor está conosco" (MACEDO, 2002, p. 122).

O que Mariano (2003) destaca desse combate à umbanda, ao candomblé e ao kardecismo é o efeito de que a legitimação dessas práticas passou a ser incorporadas pela lógica de combate, isto é, ao expulsar demônios, encostos e exorcizar os possuídos, as Igrejas neopentecostais acabam incorporando e assimilando crenças práticas e termos utilizados nas religiões que querem combater. O que Mariano (2003) aponta são as principais religiões que estão na linha de frente dessa batalha espiritual contra as forças do mal, no caso a Universal do Reino de Deus e a Internacional da Graça de Deus.

A questão da possessão demoníaca é indissociável das práticas e da autenticidade desses sistemas de crença. Não é apenas a questão da possessão e da libertação dos possessos. As apropriações sincréticas da religiosidade popular e, principalmente, de religiões afro-brasileiras. Mariano resume esses casos de visível sincretismo (MARIANO, 2003, 30):

Tal sincretismo, cumpre frisar, decorre da deliberada disposição dessas igrejas a se adaptarem à mentalidade e ao simbolismo religioso brasileiros. Atitude deliberada que encerra clara estratégia para maximizar a eficiência de seu proselitismo (MARIANO, 2003, p. 30).

O curioso dessas constatações é perceber que o mal, o diabo, os encostos, enfim, todas as hostes do inimigo, são aliados na realização das manifestações religiosas de cura e libertação, pois passam a ser invocados para manifestarem diante das sessões de descarrego para depois serem expulsos.

A ética é minimizada pelas denominações neopentecostais, pois o indivíduo não recebe a culpa pelos seus atos, a pessoa é uma vítima das artimanhas das forças do mal, sem uma autonomia e faltando determinação. Neste sentido, a 
responsabilidade do sujeito perante a sociedade é diluída por uma concepção de responsabilização dos demônios pelos transtornos ocasionados na vida da pessoa, o que leva a uma constante busca pela libertação ritual e não a uma chamada do fiel para uma reflexão e mudança comportamental.

Mariano inclui a Renascer em Cristo e a Comunidade Evangélica Sara Nossa Terra e outros grupos evangélicos que, no começo dos anos 90, difundiram a crença na batalha espiritual e que, agora, também é travada contra espíritos territoriais e hereditários.

Os demônios territoriais são elevados na hierarquia das trevas, para os neopentecostais e evangélicos do Brasil, os santos católicos têm essa função, principalmente Nossa Senhora Aparecida, por ser a padroeira da nação. Os pastores organizam os seus fiéis para lutar contra essas influências em intercessões coletivas e públicas, como grandes concentrações de fé e libertação e as Marchas para Jesus, para demonstrar força e fé dos neopentecostais pelas cidades do Brasil.

A luta contra os espíritos hereditários, de acordo com Mariano (2003), que são os responsáveis pelos problemas familiares, traz a ideia de que indivíduos, crentes ou não, têm um problema com ancestrais que pecaram ou tinham laços com os espíritos imundos ou, ainda, com práticas demoníacas. A libertação é possível com a renúncia do poder do mal e a quebra das maldições pela intercessão do poder divino.

Há reuniões religiosas de "cura interior", ou seja, a libertação de demônios, na qual priorizam aqueles que sofreram traumas. A cura é obtida através da confissão, roga-se o perdão pelos pecados dos ancestrais, pelas suas faltas cometidas e pelo ódio àqueles que os prejudicaram. Após a purificação e libertos dos demônios herdados, eles usufruem das bençãos de Deus. 
A clientela de classe média não gosta dos exorcismos e prefere psicologizar os problemas pessoais, daí a utilização das reuniões de cura interior. O que Mariano (2003) enfatiza são as atribuições dos demônios no seio do neopentecostalismo, todos os problemas cotidianos vivenciados pelos fiéis recebem o rótulo de espiritual, devido à ação do diabo e de suas legiões infernais. Portanto, Satanás é o protagonista dos rituais e religiões dos neopentecostais.

Aos fiéis neopentecostais resta cerrar as fileiras das Tropas Celestiais para guerrear contra o demônio e seus seguidores e obterem sucesso terreno e uma vida bem-sucedida para a honra é glória do Deus, que dá vida em abundância.

A mudança no cenário religioso brasileiro trouxe a violência para a pauta diária, em episódios marcantes para a sociedade brasileira. O caso do "chute na santa", episódio evolvendo o bispo da Igreja Universal do Reino de Deus, Sérgio Von Helder, que chutou uma réplica da imagem da padroeira do Brasil, Nossa Senhora Aparecida no programa do dia 12 de outubro de 1995, exibido pela Rede Record de Televisão, uma das redes de TV concedidas à IURD que tem a segunda audiência das redes abertas do país ${ }^{27}$, é um dos exemplos. Amplos setores da sociedade se manifestaram contra o ato, resultando no afastamento do bispo Sérgio do Brasil e numa enxurrada de críticas à Record, à IURD e aos neopentecostais, naquele momento.

$\mathrm{O}$ ato intolerante que provocou problemas para o povo de santo foi o ligado à lalorixá Gildásia dos Santos, a Mãe Gilda, da Casa Ilê Axé Abassá de Ogum. O terreiro de Candomblé fica nas imediações da Lagoa do Abaeté, bairro de Itapuã, na cidade de Salvador, no Estado da Bahia, que, obviamente, tem frequentadores e

\footnotetext{
27 Disponível em: <https://observatoriodatv.uol.com.br/audiencia-da-tv/2020/03/record-tv-fecha-o-mesde-fevereiro-em-segundo-lugar>. Acesso em 15 de mar de 2020.
} 
adeptos da comunidade e outros oriundos de outros estados, devido à força e tradição do Candomblé da Bahia - Estado que representa a formação e visibilização cultural do Candomblé como força dos afrodescendentes contra a opressão escravocrata e a união dos negros contra o projeto de branqueamento do início da República. No entanto, o Candomblé obteve uma maior visibilidade e tornou-se uma religião com características universais, recebendo adeptos de diversos níveis sociais e culturais, extrapolando o um aspecto de resistência racial para ser uma religião que fornece melhorias para todos aqueles que a buscam.

Mãe Gilda atuou nas manifestações públicas que reivindicavam o impedimento do então presidente da república do Brasil, Fernando Collor de Mello. O Presidente havia cometido atos lesivos aos cofres públicos e recebido vantagens indevidas para a posição que ocupava, quebrando o decoro do cargo e motivando a abertura de um processo de impeachment e de uma campanha popular, o "Fora Collor", que ocorreu em 1992.

A mídia repercutia os protestos contra o presidente e a revista Veja publicou uma capa onde aparecia a "Mãe Gilda" com as vestes sacerdotais, deitando oferendas para suplicar aos orixás uma solução para aquele triste momento da História do Brasil.

Os inimigos do povo de santo usaram a foto para o proselitismo costumeiro de suas práticas de aviltamento dos praticantes das religiões afro-brasileiras. Após sete anos, a Igreja Universal do Reino de Deus e seu jornal, a Folha Universal, publicaram a foto associando-a ao crime de charlatanismo, com o título: "Macumbeiros charlatões lesam o bolso e a vida dos clientes". O objetivo da reportagem era demonstrar o crescimento no Brasil do "mercado de enganação", 
isto é, afirmando que o mercado da adivinhação do futuro lesava os brasileiros ("Mãe Gilda" aparecia na foto de capa do jornal com uma tarja preta nos olhos).

O jornal era distribuído de graça e tinha uma ampla divulgação e, ao parar nas mãos dos frequentadores do terreiro da região, provocou uma crise, culminando no descrédito de "Mãe Gilda" e numa equivocada conclusão de que a religiosa havia se convertido à IURD, o que levou ao afastamento de fiéis. As agressões verbais e físicas a lalorixá e ao seu marido dentro do Terreiro e a quebra de objetos sagrados das dependências provocaram problemas graves que resultaram na fragilização da saúde de Mãe Gilda, que sofreu de depressão e morreu por enfarto, no dia 21 de janeiro de 2000.

As consequências da morte de Mãe Gilda provocaram uma reação que Reinhardt (2007) assinalou como "o inimigo que faltava" para provocar uma união dos afro-religiosos e o surgimento do Movimento Contra a Intolerância Religiosa (MCIR), que surge no ano 2000. No ano em questão, também foi criado o Fórum Baiano Contra a Intolerância Religiosa. A defesa do povo de santo contra a intolerância religiosa dos grupos neopentecostais que, aos participantes do Fórum, foram identificados como segregacionistas, religiosos agressivos e proselitistas, proponentes de uma modernização opressiva e homogeneizante, autoritários e falsos evangélicos, vem crescendo e tomando formas de ações para diminuir os ataques e atuar na defesa e respeitabilidade das religiões afro-brasileiras. Já as religiões de comunidades tradicionais de terreiro foram apontadas como religião espiritualista e não expansionista, os intelectuais defenderam a "cultura baiana", sincrética e aberta ao outro; as lideranças religiosas defendiam a "liberdade religiosa" e as lideranças do Candomblé desejavam a paz para cultuar os orixás e os ancestrais. 
Com o reforço do movimento negro e a política partidária local, a temática da intolerância religiosa saiu do âmbito religiosos e iniciou um contorno político, isto é, os afro-religiosos achavam que essa perseguição era um movimento político e outros denominaram esses ataques a um racismo comum na cidade de Salvador.

A vitória dos povos de santo no caso de Mãe Gilda teve o apoio de diversos atores sociais, como relata Reinhardt

\begin{abstract}
O apoio do Ministério Público foi acrescido pela ONG ecumênica Koinonia, e pela Associação dos Advogados dos Trabalhadores Rurais (AATR), que disponibilizaram a assessoria jurídica para a abertura do processo, em janeiro de 2000. A partir de então, a causa é progressivamente divulgada, e passa a receber apoio de instituições a princípio alheias ao problema, como a imprensa e setores do movimento negro. Vindo a tornar-se o ícone do Movimento Contra a Intolerância Religiosa, mãe Gilda tem o dia da sua morte instituído pela Câmara dos Vereadores, em 2004, como o "Dia Municipal de Combate à Intolerância Religiosa", demonstrando que a essa época o termo já se estabilizara enquanto categoria política, até mesmo dentre o povo de santo, fazendo-se presente no tradicional terreiro Axé Opó Afonjá, em 2003, como principal tema de debate do Alaindê Xirê daquele ano, a Semana da Herança Africana ${ }^{28}$ (REINHARDT, 2007, p. 157/158).
\end{abstract}

O dia 21 de janeiro de 2000 passou a ser o Dia Nacional de Combate à Intolerância Religiosa.

A Justiça, no início do ano de 2004, condenou a IURD na primeira instância, tanto a Igreja quanto a gráfica (Gráfica Universal), a pagar indenização à família de Mãe Gilda no valor de $\mathrm{R} \$ 1.372 .000$, correspondendo à tiragem dos exemplares do jornal Folha Universal, que estampou a foto da lalorixá na capa, no ano de 1999.

Os dados do Relatório Intolerância Religiosa no Brasil (2016), informando como fonte Secretária de Direitos Humanos (SDH), atestam que, de 2011 a dezembro de 2015, foram registrados 697 casos informados através do disque 100, serviço criado para quantificar as denúncias de práticas de discriminação.

\footnotetext{
28 A reunião contou com a presença do bispo Gilio Felício, responsável pela implantação da Pastoral Afro na Bahia, e que viria, naquele ano, a assumir a Diocese de Bagé. A despedida de bispo Felício da cidade ainda resultou em um encontro com representantes de 20 terreiros, cuja tônica continuou sendo "uma manifestação de repúdio aos segmentos das igrejas evangélicas que têm criticado o sincretismo religioso na Bahia" ("Afros e católicos unidos contra a intolerância." A Tarde, 16/01/03), que conteve a negritude como eixo inter-religioso e o racismo como principal categoria de acusação.
} 
O ponto máximo das denúncias foi no ano de 2013, uma baixa em 2014 e no ano seguinte um novo incremento dos casos (SANTOS et al., 2018, p. 22).

O caso do Estado do Rio de Janeiro merece destaque, pois foi o Centro de Promoção da Liberdade Religiosa e Direitos Humanos (CEPLIR) que acompanhou o atendimento as vítimas dos ataques intolerantes pela forma presencial e telefone, com os números: 1014 atendimentos, entre julho de 2012 a setembro de 2015; e 66 atendimentos de setembro a dezembro de 2015 (SANTOS et al., 2018, p. 23).

O primeiro período apresenta um total de $71,5 \%$ de denúncias de ataques direcionados aos seguimentos das religiões de comunidades tradicionais de terreiro e uma maior incidência de vítimas contra o povo de santo. O segundo período tem números diferenciados: $32 \%$ de ataques aos muçulmanos; $30 \%$ dos candomblecistas; $6 \%$ indígenas; $5 \%$ agnósticos; $5 \%$ pagãos e $3 \%$ kardecistas. No segundo relatório, devido ao trabalho de campanhas intensivas para o aumento do prestígio religioso do povo de santo, os números foram diferenciados em relação ao primeiro relatório. No balanço do segundo relatório, cabe destacar que o cenário de intolerância contra muçulmanos, dada a conjuntura internacional de avanço do Estado Islâmico somado à Guerra Civil na Síria e ao aumento do extremismo de direita no Brasil, provocou um incremento dos casos contra os muçulmanos (SANTOS et al., 2018, p. 24).

Já a Comissão de Combate a Intolerância Religiosa (CCIR) registrou, no período de 2008 a 2014, 57 denúncias, com 39 registros em boletins de ocorrência e início de processos. O maior número de ataques sofridos foram aqueles contra as religiões de comunidades tradicionais de terreiro, com um total de 15 ocorrências (Ibid., 25). Os casos de intolerância surgiram a partir dos denunciantes e tendo como bases a Secretaria de Direitos Humanos através do disque 100, CEPLIR (Centro de 
Promoção da Liberdade Religiosa e Direitos Humanos), o CCIR (Comissão de Combate à Intolerância Religiosa) FIERJ (Federação Israelita do Estado do Rio de Janeiro), totalizando 1407 denúncias.

O relatório apresenta a questão dos atos de intolerância registrados em notícias impressas ou virtuais. As instituições responsáveis por estes dados são a Sociedade Beneficente Mulçumana do Rio de Janeiro (SBMRJ) e a Presença Ecumênica em Serviço (KOINONIA). As instituições coletaram fontes nas notícias impressas e virtuais totalizando 133 casos. O relatório aponta que a SBMRJ denunciou ataques islamofóbicos virtuais e de ataques aos mulçumanos no Brasil. No entanto, o que foi informado não apontou quais casos foram registrados em boletim de ocorrência (BO). Os casos de intolerância religiosa praticados nos meios virtuais sofreram um incremento dada a uma certa "liberdade de expressão" reivindicada pelos intolerantes nos meios virtuais (SANTOS et al., 2018, p. 27).

O relatório traz informações preciosas sobre as vítimas dos atos intolerantes por Grupo Sócio Etário (GSE), de 2011 a 2015, no Brasil. Os autores chamam a atenção para grupos que são vítimas em questão, no caso temos: "crianças e adolescentes, comunidade LGBT, idosos e deficientes físicos". O auge desses ataques neste período considerado pelos autores são os anos de 2012 e 2013 (SANTOS et al., 2018, p. 29). O critério de cor/raça, de acordo com o relatório, foi relatado três grupos: "brancos, pardos e negros." Pardos e negros correspondentes ao percentual de $34,66 \%$ e os brancos têm um total de $22,38 \%$, inferior ao de pardos e negros. No tocante ao gênero das vítimas, temos uma equivalência, até o ano de 2013; já no ano de 2014, há uma presença maior de homens denunciantes dos ataques intolerantes (SANTOS et al., 2018, p. 30). 
Quanto a orientação sexual, entre 2011 e 2015, foi observado uma presença da categoria "não informado" bem elevado. A declaração das orientações de bissexuais, gays, lésbicas, travesti possui uma baixa presença no relatório. Os autores do relatório constataram que uma elevada declaração de "não informado" talvez seja por não ter a categoria heterossexuais e também porque os denunciantes não declaram a orientação sexual por fatores como medo ou vergonha (SANTOS et al., 2018, p. 31).

Há um total de 891 dos indicadores de suspeitos e agressores, constatado pelos autores do relatório, um número total de atendimentos do SEPPIR (Secretaria de Políticas de Promoção da Igualdade Racial) inferior em relação aos casos contatados no total de suspeitos/agressores. Os tipos característicos dos agressores ou suspeitos são os vizinhos, com um total de $26,94 \%$ e desconhecidos $29,40 \%$. A categoria "não informado" tem um valor elevado, na constatação dos autores do relatório. Uma explicação possível para esse número seria a forma de coletar informações, já que o atendimento por telefone, devido a rapidez, levaria à supressão de questionamentos e à situação de constrangimento ao qual se encontra a vítima.

A intolerância religiosa observada pelos autores atinge as residências, locais de trabalho e ensino dos brasileiros. Chama a atenção dos autores a presença desse tipo de atos intolerantes praticados num ambiente que deveria ajudar na formação cidadã e tolerante do indivíduo, e não no reforço de problemas arraigados desde a sua formação, o que, de certa forma, dificulta o combate à intolerância religiosa no Brasil (SANTOS et al., 2018, p. 32)

Os novos inimigos das religiões afro-brasileiras são mais empenhados e mais decididos. A grande perseguição que as religiões afro-brasileiras sofreram pela 
imprensa, polícia e demais agentes fez parte do passado de luta do povo de santo. Contudo, as religiões que passam a competir com os terreiros, as igrejas evangélicas, particularmente, as denominações neopentecostais, procuram, através de uma ligação com o Estado, causar transformações nas leis para fortalecerem as suas organizações proselitistas e altamente competitivas no atual cenário religioso brasileiro (PRANDI; JÁCOMO; BERNARDO, 2019, p. 107).

Mesmo com as liberdades religiosas da Constituição de 1988, os novos atores e inimigos declarados das religiões de comunidades tradicionais de terreiro buscam criar regras legais que dificultem 0 abate religioso nos terreiros interrompendo a ligação entre homens e entidades, atributo vital para os rituais do panteão afro-brasileiro.

Prandi identifica a década de 1990 por muitos trabalhos de pesquisadores ligados às religiões que identificam a temática do confronto entre evangélicos e afrobrasileiros. As pesquisas apontam para as agressões constantes e sistematizadas aos afro-religiosos por parte de setores evangélicos comprometidos com o que eles chamam de "conflito", "batalha", "batalha espiritual" e "guerra santa", de acordo com os pesquisadores como se fossem dois lados medindo forças.

O mal, já não estava apenas na figura do diabo do cristianismo, mas das representações das entidades e divindades sagradas das religiões afro-brasileiras. Portanto, nos locais comunidades tradicionais de terreiro estava o mal e a luta contra o diabo, que deveriam obedecer a uma lógica do extermínio (SANTOS et al., 2018, p. 108). Um desses pesquisadores, Ricardo Mariano, em sua investigação, demonstra o avanço sobre os terreiros afro-brasileiros (MARIANO, 2003), onde, nessa "batalha espiritual", revela um lado perdedor muito bem definido. $\mathrm{O}$ alvo das investidas evangélicas eram as religiões afro-brasileiras. Nessas pequenas religiões 
de comunidades tradicionais de terreiro conseguiram, ao longo do tempo, uma visibilidade impressionante graças a sua influência cultural no Brasil.

Ações dos evangélicos sobre denominações católicas revelam um caráter menos belicoso. Exceto o caso do "chute na santa", ocorrido no ano de 1995 durante um programa rede Record de televisão. Um bispo da Igreja Universal do Reino de Deus (IURD), diante da imagem de Nossa Senhora Aparecida, padroeira do Brasil, não se conteve em dizer que era apenas uma imagem, ou seja, passou a xingar e a desferir pontapés na santa, o que causou uma enorme comoção na sociedade brasileira. Mas quando as religiões afro-brasileiras, seus símbolos e rituais, sofrem todos os tipos de agressões, por mais que seja estranho, não há nenhuma comoção e há até a alegria de muitos (SANTOS et al., 2018, p. 109).

Os ataques dos evangélicos tem as características parecidas com ações isoladas, isto é, ataques diretos, ofensas dirigidas aos seguidores e a destruição dos templos, parecido com uma ação terrorista, onde procura-se danificar o máximo possível os objetos religiosos, a quebra, e, de preferência, o fogo no local religioso do povo de santo.

De uma outra maneira, os representantes evangélicos que atuam nas casas legislativas municipais, estaduais e da União, buscam maneiras legais para criar barreiras e prejudicar os afro-religiosos, na sua prática e no seu ritual. Outros legisladores, ligados aos católicos e aos que advogam em prol dos direitos dos animais, procuram obstaculizar os rituais, isto é, o sacrifício votivo, o abate para fins religiosos, uma forma ritualística na qual as divindades precisam ser alimentadas. Estes sacrifícios têm seus rituais presentes no judaísmo, no cristianismo e em várias religiões no mundo. Todavia, a associação do sacrifício à magia negra, que 
popularmente recebe o nome de "macumba" 29 - conotação carregada de preconceito - demonstra a forma de ataque constante aos rituais afro-brasileiros.

Aqueles que defendem o fim do abate religioso utilizam a Constituição de 1988, em seu artigo 225 , parágrafo $1^{\circ}$, inciso $\mathrm{VII}$, que determina a responsabilidade do Estado "proteger a fauna e a flora, vedadas na forma da lei, as práticas que coloquem em risco sua função ecológica, provoquem a extinção de espécies ou submetam os animais a crueldade".

Já os que recorrem aos tribunais superiores, anulando as leis municipais e estaduais de vedação de sacrifícios, também através da Carta Magna atual, se utilizam do artigo $5^{\circ}$, inciso VI, que diz que "é inviolável a liberdade de consciência e de crença, sendo assegurado o livre exercício religioso e garantida, na forma da lei, a proteção aos locais religiosos e a suas liturgias".

Os autores lembram que essa defesa dos animais não tem atuação prática, dada a ineficiência deles em relação à ação dos pecuaristas e dos frigoríficos, isto é, a "indústria da carne", que leva os animais a crueldades imensas só para a satisfação de consumidores exigentes de proteína animal (SANTOS et al., 2018).

O preconceito religioso (SANTOS et al., 2018, p. 111) fica disfarçado de proteção aos animais. Essa situação, de acordo com os autores, foi resolvida pelo Supremo Tribunal Federal (STF), no mês de março do ano passado, pela votação do Recurso Extraordinário 494601. A garantia dada pelo pleno do Supremo foi que a liberdade religiosa e do ritual do abate, seguindo as tradições, é superior à defesa dos direitos dos animais.

\footnotetext{
${ }^{29}$ A expressão macumba vem muito provavelmente do quicongo kumba: feiticeiro (o prefixo "ma", no quicongo, forma o plural). Kumba também designa os encantadores das palavras, poetas.

Macumba seria, então, a terra dos poetas do feitiço; os encantadores de corpos e palavras que podem fustigar e atazanar a razão intransigente e propor maneiras plurais de reexistência pela radicalidade do encanto, em meio às doenças geradas pela retidão castradora do mundo como experiência singular de morte. (SIMAS \& RUFINO, $2018,4)$
} 
A crueldade com os animais, principal alegação dos defensores do fim do abate, caiu por decisão da maioria da mais alta corte do Judiciário Brasileiro, que definiu a legalidade do sacrifício votivo das religiões afro-brasileiras.

De acordo com Prandi (2017), as religiões de matriz africana são uma reprodução da família africana reconstituída de forma simbólica, isto é, cada terreiro reproduz uma pequena dimensão da família africana. Portanto, o racismo estava escondido na legalidade de não maltratar os animais e impedir o abate e, ao lograr o acatamento da lei, o ritual votivo impedido seria o mesmo que não realizar a adoração aos orixás (SANTOS et al., 2018, p. 112).

De acordo com os autores, estudos atuais tratam da temática intolerância religiosa (SILVA, 2007), dizendo que, devido às dificuldades de uma formação originária e organizacional em pequenos grupos, sem uma centralização os terreiros, estes esboçam uma reação através dos meios jurídicos, enfrentando situações processuais que esbarram na morosidade e nas diversas instâncias do Judiciário.

Devemos destacar a liderança do Doutor Hédio Silva Júnior, que atua na defesa do povo de santo (SILVA JR., 2007). Devido ao constante acionamento da justiça, dada a intensidade dos ataques aos afro-religiosos, Silva Jr. busca capacitar os seguidores na defesa das religiões afro-brasileiras. Sua atuação na promoção de palestras, reuniões, cartilhas, folhetos e a atuação nos tribunais e sua atuação no STF na defesa do abate votivo das religiões de comunidades tradicionais de terreiro merecem destaque (SANTOS et al., 2018, p. 113).

Outros atores sociais têm mobilizado esforços para defender, dar visibilidade e continuar processos contra as agressões sofridas, devido ao seu vínculo religioso afro-brasileiro. No ano de 2018, a Secretaria Nacional de Cidadania do Ministério dos Direitos Humanos realizou a publicação da obra "Estado laico, intolerância e 
diversidade religiosa no Brasil: pesquisas, reflexões e debates, organizado por Alexandre Brasil da Fonseca, que traz o Relatório sobre Intolerância e Violência Religiosa no Brasil (Rivir)".

Os números do relatório tratam de um período compreendido entre 2011 e 2015, somente casos registrados e com processos caracterizados pelos atos de intolerância religiosa, denúncias e notícias na imprensa brasileira crescem constantemente. Num total de 965 casos

$35 \%$ das vítimas pertencem a religiões afro-brasileiras, $19 \%$ são
evangélicas, $8 \%$ são católicas, $4 \%$ são espíritas, $2 \%$ são muçulmanas e $9 \%$
são de outras religiões, não havendo informações sobre religião para $23 \%$
dos casos (FONSECA, 2017, tab. 2).

Ao demonstrar os segmentos religiosos, temos o percentual como vítimas: "os afro-brasileiros aparecem como vítimas em $98 \%$ dos casos, os espíritas em $87 \%$, os católicos em $69 \%$ e os evangélicos em $51 \%$ dos casos (FONSECA, 2017, tab. 2)."

No levantamento dos números percentuais dos agressores, temos: " $49 \%$ dos evangélicos, $31 \%$ dos católicos, $13 \%$ dos espíritas e $2 \%$ dos afro-brasileiros (FONSECA, 2017, gráf. 3)".

A identificação do agressor não é fácil e quando se trata da sua religião temos dificuldades de uma caracterização, dadas as circunstâncias às quais temos o fato da intolerância religiosa, a forma da abordagem e do ataque desferido. Em muitos casos, a ação intolerante foi praticada quando os afro-religiosos se encontravam fora do horário das manifestações religiosas e do recinto e o agressor aproveitou-se do anonimato e, às vezes, da conivência da comunidade que não deseja aquela casa funcionando no local. Mas quando analisamos os casos da religião da vítima e do agressor como fatores conhecidos, a definição dos números e da proporção dos 
atos intolerantes aos quais os fiéis das religiões afro-brasileiras são vítimas, tudo fica evidente

\begin{abstract}
As vítimas afro-brasileiras são agredidas por evangélicos em $78 \%$ dos casos, por católicos em $16 \%$, por ateus em $4 \%$ e por outros afro-brasileiros em $2 \%$ dos casos. Quando as vítimas são evangélicas, seus agressores são classificados: $70 \%$ são outros evangélicos, $15 \%$ são católicos, $10 \%$ são espíritas e $5 \%$ são ateus. No caso das vítimas católicas, seus agressores assim se classificam: $73 \%$ são evangélicos, $20 \%$ são outros católicos e $7 \%$ são ateus. Não há registro de agressores das religiões afro-brasileiras contra evangélicos, católicos ou espíritas (FONSECA, 2017, gráf. 4).
\end{abstract}

Outra publicação do ano de 2018, em edição bilíngue (português e inglês), da obra "Intolerância religiosa no Brasil: relatório e balanço", coordenada pelo Babalaô Ivanir dos Santos e outros autores, apresenta uma diversidade de casos de intolerância (FONSECA, 2017, p. 115).

O relatório surgiu de uma contribuição de diversas entidades que registraram ocorrências e passaram a contabilizar dados de intolerância religiosa, principalmente no estado do Rio de Janeiro (SANTOS et al., 2018). As religiões de comunidades tradicionais de terreiro lideram os índices de vítimas da intolerância religiosa. Os autores chamam a atenção por um dado da pesquisa que é o "Mapeamento de terreiros" realizado pela Pontifícia Universidade Católica do Rio de Janeiro (PUC $\mathrm{RJ}$ ), onde foi identificado um percentual significativo

Quase $70 \%$ dos casos de intolerância atingem terreiros pequenos, com até 50 frequentadores" apresentando, neste caso, uma alta taxa de vulnerabilidade. Desse total, "apenas $15 \%$ dessas agressões levaram a algum tipo de representação na polícia ou em entidades de denúncias (SANTOS et al., 2018, p. 34/36)

Ao apontar os resultados dos relatórios, os autores constataram que, liderando os atos intolerantes, aparecem os evangélicos como responsáveis pelas supostas ações; já os fiéis das religiões de matriz africana, as vítimas das ações intolerantes. Essa perseguição aos afro-religiosos remontam a um trágico drama do passado que parecia ter acabado, mas as suas reações iniciais são de esconderem, 
como no passado, a confissão religiosa, nas escolas principalmente, onde as "crianças iniciadas no candomblé ou umbanda são obrigadas a ocultar a pertença religiosa," deixam de usar os símbolos que marcam a identificação religiosa e calando diante das piadas dos colegas e, muitos casos, da omissão dos professores no cotidiano escolar de intolerância religiosa (FONSECA, 2017; BERNARDO et al., 2017).

A intolerância já está bem evidenciada, após a demonstração desses dados alarmantes e preocupantes com o futuro dos fiéis das religiões afro-brasileiras. $\mathrm{O}$ período posterior aos relatórios, conforme os autores constatam, revela uma situação bem pior. De acordo matéria do jornal Folha de São Paulo, os autores revelam um período comparando os meses de agosto a outubro de 2018 - época da campanha para Presidência, trazendo questões polêmicas para a sociedade - com os meses de maio a julho de 2019. Ficou constatado o aumento dos casos de intolerância nos diferentes aspectos considerados: 15\% com relação a raça ou cor, $75 \%$, por se tratar de homofobia ou transfobia, $83 \%$ questões ligados à origem geográfica e de nacionalidade e, para piorar, $171 \%$ de aumento dos casos de intolerância religiosa ${ }^{30}$.

Demonstra-se, com os estudos de Prandi, Jácomo e Bernardo, uma mudança de características das pesquisas relacionadas as religiões afro-brasileiras, isto é, investigar a ligação dessa religião com os aspectos da triste realidade nacional. $O$ que interessa é pesquisar e entender como a religião de comunidades tradicionais de terreiro vislumbra a realidade que a cerca: marginalidade social, criminalidade,

\footnotetext{
${ }^{30}$ Matéria completa disponível em: https://www1.folha.uol.com.br/cotidiano/2019/01/registros-de-intoleranciatriplicaram-em-sp-na-ultima-campanha-eleitoral.shtml. Acessado em: 12 de abril de 2019
} 
questões identitárias fora do padrão, questões de gênero e situações conflitivas raciais nas escolas e instituições não religiosas (BERNARDO et al., 2017, p. 116).

As religiões afro-brasileiras entram no esquema explicativo como um dado independente e, a partir desse dado principal, busca-se explicar aspectos nacionais, inclusive aspectos negativos para servir de munição para aqueles que querem inferiorizá-las (PRANDI, 2005). A tendência atual é colocar as religiões de comunidades tradicionais de terreiro como vítimas da expansão dos evangélicos em todos os níveis e, principalmente, no poder político. Entretanto, a reação afrobrasileira está nos projetos de defesa, nas vitórias jurídicas, mas, na política, o crescimento é ínfimo ou inexistente, poucos representantes.

O atual governo federal, de acordo com os autores, não projeta um futuro confortável e de menos intolerância para as religiões afro-brasileiras, mormente se for considerado a influência evangélica nos diversos escalões do Governo.

Desde a caminhada eleitoral até os atos do governo de Jair Bolsonaro, a democracia tem perdido espaço e a defesa das minorias, das liberdades, do pensamento crítico, do pluralismo político, da diversidade de gênero, das conquistas feministas, das novas visões de família, dos indígenas e quilombolas, dos sem-teto, dos sem-terra e, é claro, das tradições religiosas afro-brasileiras e do seu rico legado. Resumindo, os direitos das "minorias", receberam, após as escolhas do pleito de 2018, uma resposta que representa bem o sentimento dos atuais mandatários para com todas essas demandas sociais e direitos humanos. $\mathrm{Na}$ voz da dita maioria vencedora: - As minorias? Elas que se adaptem a não ter direitos, ou seja, elas que se danem! (PRANDI, 2005, p. 117). 


\section{O RACISMO RELIGIOSO}

Sobre essa temática do racismo Djamila Ribeiro diz, em sua obra Pequeno Manual Antirracista

O racismo é, portanto, um sistema de opressão que nega direitos, e não um simples ato da vontade do indivíduo." Assim como o "racismo é um sistema de opressão", a sua faceta religiosa, o racismo religioso, não é um ato individualizado e muito menos de pequenas denominações religiosas e muito menos, disputa religiosa, é um sistema de opressão que impede a pessoa de ser livre na sua escolha religiosa e que seja respeitada a sua fé, sem ofensas e sem demonizações (RIBEIRO, Djamila, 2019, p. 12).

Ao depararmos com os insistentes atos intolerantes, que parecem não ter fim, mesmo após todos os apelos, o rigor da lei e as mobilizações dos praticantes das religiões de comunidades tradicionais de terreiro, uma saída aceitável para as constantes ações repulsivas contra o povo de santo está na questão do racismo religioso e a sua raiz em nosso passado colonial, como atesta a autora do artigo e a defesa de sua hipótese

O que sustenta a hipótese de racismo religioso, nos casos de manifestações contra religiões de matriz africana, é exatamente a afirmação da africanidade que a prática religiosa carrega - o contexto no qual os africanos foram trazidos ao país, e as representações do negro (fenótipo, cultura e cosmovisões) são o fator gerador - a característica grupal - da discriminação (FERNANDES, 2017, p. 132).

Essa transformação do ambiente não é uma novidade, a história de colonização e imposição de uma mão de obra escravizada permitiu a construção desse ambiente hostil para com os nativos e o africano e com o que eles representavam no projeto de nação.

O racismo no saber proporciona a deslegitimização dos saberes afrobrasileiros e no ambiente acadêmico, por consequência no cotidiano escolar, e, também, no cotidiano dos brasileiros em geral, como afirma Oliveira em sua dissertação 
A estratégia da leitura desta dissertação vai no sentido de dizer que o racismo epistêmico atua na discriminação das religiões afro-brasileiras por si, respaldando as violações, os ataques, a criminalização dessas religiões e suas práticas e não somente isentando o seu aparecimento como válido dentro de ambientes acadêmicos (OLIVEIRA, 2017, p. 12).

Ela também demonstra que a colonialidade do poder é estruturada pelo racismo e ele não concebe como religiosidade práticas, que não condizem com os padrões estéticos e elitistas da sociedade moderna ocidental ao qual o Brasil busca como referência de padrão para nortear a sociedade em questão

\begin{abstract}
A colonialidade do poder tem como eixo estruturante o racismo e esse racismo finda por hierarquizar de forma a inferiorizar tudo o que não é derivado do padrão eurocêntrico da racionalidade moderna ocidental. Nesse processo, as religiões afro-brasileiras e suas práticas foram excluídas do arcabouço considerado válido tendo seu modo de produção e transmissão de conhecimento e toda a sua forma de compreensão e expressão de seu cosmo próprio rechaçados por não corresponderem aos padrões da racionalidade moderna, o que caracterizou, por sua vez, o racismo epistêmico com relação a essas religiões (OLIVEIRA, 2017, p. 15).
\end{abstract}

A necessidade de compreender a intolerância religiosa sofrida pelos praticantes das religiões de matriz africana leva a triste constatação de que ele é um fenômeno resistente e recorrente na história do Brasil e, desde a formação dessas religiões até o atual estágio constatado, devido à base da sociedade - que é movida pelo racismo - e as violências perpetradas aos afro-religiosos é fruto do racismo religioso, que está presente em grande parte da sociedade brasileira, como constata Ariadne Moreira Basílio de Oliveira, em sua dissertação

Tendo como base a compreensão de que a discriminação que as religiões afro-brasileiras sofrem é racismo, a categoria de intolerância se mostra insuficiente para categorizar este fenômeno. A intolerância é tratada como reflexo de um ato individual, o reflexo de um indivíduo como intolerante, ou no máximo o de um grupo, direcionado contra outro indivíduo. As violências que as religiões afro-brasileiras sofrem são, por outro lado, direcionadas à sua configuração e as influências afro-ameríndias que representam, sendo, além disso e consequentemente, reflexo de um racismo estrutural brasileiro. Não se trata de um ato individual contra outros indivíduos, se trata de um racismo basilar em nossa sociedade, presente também nas instituições estatais e se reflete, entre outros momentos e formas, nos preconceitos, discriminações, ataques e violações que aqueles que vivem as religiões afro-brasileiras sofrem (OLIVEIRA, 2017, p. 15/16). 
Sobre a questão racial podemos observar, de acordo com Oliveira, e ao citar Mbembe, que faz uma crítica a modernidade e a questão da raça, que ao não ser questionada, não contestará as dominações racistas que tem como base a formação de uma sociedade moderna e excludente para as raças ditas inferiores e as suas expressões culturais e religiosas

(...) raça é uma categoria construída histórico-socialmente e que há uma especificidade na ideia de raça forjada na modernidade que associa a diferenciação cultural e os valores morais de acordo com características fenotípicas e biológicas para a justificação da dominação. Para Mbembe, a crítica à modernidade não será realmente efetiva se não for questionado o princípio de raça: Permanecerá inacabada a crítica da modernidade, enquanto não compreendermos que seu advento coincide com o surgir do princípio de raça e com a lenta transformação deste princípio em paradigma principal, ontem como hoje, para as técnicas de dominação (OLIVEIRA, 2017, p. 19/20 e 23 apud MBEMBE, 2014. p. 102).

O processo de inferiorização tem como categoria a questão racial e não se deve negar que este critério ajudou na construção da modernidade e na exclusão e destruição dos dominados para justificar a expansão imperialista e da "superioridade cristã", como afirma a autora, que citará Rita Segato

A classificação da raça é proveniente de uma leitura de traços fenotípicos, ou seja, da assunção de que características físicas, como em especial a cor da pele, diz sobre a característica de uma população em desconsideração total das construções históricas que, inclusive, originaram dominantes e dominados. Aos dominados foi relegada a inferioridade, contudo associada a uma característica física e não como consequência de uma situação histórica. Rita Segato, situa, por sua vez, o racismo historicamente ao dizer: El racismo es siempre un producto de la historia, es decir, de relaciones que se dieron, históricamente, entre pueblos, con sus respectivas marcas raciales. El racismo es la consecuencia de la lectura, en los cuerpos, de la historia de un pueblo. Es la lectura del aspecto físico de los pueblos en tanto que vencedores y vencidos, y la atribución automática, prejuiciosa, de características intelectuales y morales que, de forma alguna, son inherentes a esos cuerpos ((OLIVEIRA, 2017, p. 24 apud SEGATO, 2007a, p. 72).

A ambição dos europeus somado ao fanatismo dos contra reformistas transformaram a América em um ambiente marcado pelo racismo, e o racismo religioso tem usas origens nesta montagem da estrutura colonial aqui no continente americano, principalmente, nas porções conquistadas pelos Ibéricos e sua ânsia de 
moldar as estruturas da Igreja Católica aos povos nativos e aos africanos escravizados e forçados a trabalharem nestas terras, conforme defende a autora

O regime senhorial da península ibérica foi dominado pela Contrarreforma e pela Inquisição que decretaram a expulsão dos chamados mouros e judeus impondo um colonialismo interno, em detrimento das expressões identitárias dos povos que conviviam nessa sociedade. A violência e a rigidez da Contrarreforma geraram uma pretensa homogeneização social que foi replicada na conquista da América e que serviu como molde, sendo parte do processo do posterior desenvolvimento dos Estados-nação europeus. Ou seja, a conquista da península ibérica criou padrões de poder e violência que puderam ser replicados aqui na América, assim como os preconceitos impetrados a partir dessa visão estrita de como deve ser forjada a sociedade ora dominada (OLIVEIRA, 2017, p. 20).

A dominação racial não pode ser uma categoria esquecida ou não lembrada

neste aspecto de formação de nossa sociedade racista e elitista, e que não renunciará ao fator dominação tão facilmente. O modelo de modernidade trazido para as colônias transforma essas terras em fornecedoras de riquezas para a Europa, que, com as conquistas colônias, transformam-se em centro do mundo, conforme ressalta a autora, de acordo com quem, ao citar Quijano, isso formará a colonialidade do poder

A construção do centro-norte europeu, caracterizado pelos por países como Alemanha, França e Inglaterra, como a representação do ápice civilizatório da humanidade decorre da perda de poder da península ibérica que foram os países que principiaram a colonização de outras regiões e que despontaram na acumulação de riqueza devido à exploração de suas colônias. O centro-norte europeu, que conseguiu desenvolver uma classe média atuante e impetrar trocas comerciais com outros países assim como na colonização de outras regiões, passa a despontar, portanto, como o centro do mundo. Fato que também foi possível devido à conquista e colonização da América que se tornou a primeira periferia da Europa e, ao mesmo tempo, constituiu a Europa enquanto centro. Para Quijano este processo de colonização da América Latina colocou a Europa como o centro do poder de forma mundial e deu início a dita modernidade. A modernidade, segundo a perspectiva decolonial, é iniciada com a chegada a América, pois é a partir da América que a Europa se constrói como centro mundial e se consolida com a propagação, através da colonização de outras regiões, o seu padrão de poder (OLIVEIRA, 2017, p. 21 apud QUIJANO, 2005a).

Nessa "conquista da América", o outro não é tratado como um outro e sim

como alguém conhecido, de acordo com a autora, que cita Dussel (1994, p. 23) 
chamando esse outro de "invenção do ser-asiático na América" (OLIVEIRA, 2017, p. 21).

Na modernidade, a América Latina continua com essa provedora de riquezas para os países desenvolvidos, tendo como base uma exclusão e repressão constante de todos os que se opõem ao padrão de ser humano, ou seja, o eurocentrismo e as suas consequências nefastas na vida cotidiana e na religiosidade em questão, ao qual a religiosidade do outro é inferiorizada e somente é aceitável o padrão correspondente ao imposto pelos europeus, como afirma Oliveira

\begin{abstract}
Mesmo que Colombo tenha sabido de que as terras em que havia desembarcado não fosse as índias, com a confirmação posterior da chegada a uma outra terra, feita por Américo Vespúcio, de que a terra a qual ele e Colombo chegaram não era conhecida pelos europeus, o Outro ainda é visto como ele, que necessita ser dominado, colonizado, civilizado. Isto porque este foi o momento da construção do modelo europeu como padrão universal que as outras sociedades deveriam seguir. Era o nascimento do eurocentrismo, em que o outro é rechaçado, inferiorizado e só tem valor à medida que é identificado com o padrão ocidental. Os europeus se tornam, então, os missionários, empenhados no mito salvacionista que justificou a empreitada das conquistas nessas terras (OLIVEIRA, 2017, p. 22).
\end{abstract}

Fora da salvação proposta pelos europeus, tudo é perdição e está ligado ao mal, daí a inferiorização das religiões afro-brasileiras e de seus seguidores, que sempre está identificada como algo que levará a pessoa à loucura e a insanidade, ou ainda, falta de cultura. Como demonstra a autora, que assertivamente constata a destruição promovida por critérios fenotípicos levaram à destruição da cultura e da racionalidade do subjugado - que, para os europeus, é desprovido de razão e de fé. Ou seja, um racismo epistêmico, que Quijano chama de "colonização dos imaginários"

Com a categorização da raça, como mostrado anteriormente, há uma associação da diferença biológica, fenotípica e associação de que essa diferença reflete também em uma diferença implícita cultural. Isso é estabelecido a partir do desenvolvimento da racionalidade-modernidade, ou 
racionalidade moderna, estruturada a partir da hierarquização das (povos) populações, seus conhecimentos e saberes, e da colonização do imaginário dos povos indígenas e africanos trazendo uma imbricação entre a colonialidade do saber, a destruição do imaginário e o racismo epistêmico. A partir do desenvolvimento do padrão de poder europeu e sua expansão para os cinco continentes, houve também a expansão da forma de dominação utilizando de forma estratégica a racialização e colonização dos imaginários, da subjetividade, da cultura, da produção e transmissão de conhecimento (OLIVEIRA, 2017, p. 24 apud QUIJANO, 2014b, 2014c).

\title{
A Europa é rotulada como o continente da superioridade em todos os sentidos
}

e imprime a sua dominação de todas as formas, em todos os meios, e, principalmente, subjuga os povos dominados não só militarmente, irá impor a sua cultura e a sua religião, como "missão civilizadora e salvacionista" aos selvagens, como atesta a autora ao citar Quijano

\begin{abstract}
Quijano afirma que o termo Europa indica uma identidade que foi forjada a partir de relações com outros povos e culturas, já que as identidades são relacionais, contudo essas culturas não europeias, não ocidentais, não foram reconhecidas como tal, mas sim associadas a natureza, já que, segundo essa forma de conhecimento que estava se desenvolvendo naquele momento, o único povo que poderia ter indivíduos, sujeitos, ser racional, seria o europeu, os demais foram categorizados como diferentes e a diferença é associada a uma hierarquia de inferiorização. Portanto, os outros povos só poderiam ser objetos de conhecimento ou de dominação. A partir disso se bloqueia todas as formas de trocas interculturais, já que na relação entre sujeito - objeto só é possível uma relação de exterioridade (OLIVEIRA, 2017, p. 25 apud QUIJANO, 2014b).
\end{abstract}

A pior forma de dominação é a cultural, ou seja, a "colonização do imaginário",

destrói o outro, imprime a inferiorização total, descaracterizando-os em seus

conhecimentos, expressões culturais e suas práticas religiosas. Como afirma

Oliveira, essa colonização imprimia a dominação totalizante e a produção do saber

nos moldes europeus

Em consequência dessa racional-modernidade em que o outro só poderia ser objetificado e dominado, houve a repressão das formas de produção de conhecimento de sociedades colonizadas, assim como suas crenças, sua produção imagética, suas expressões artísticas, o que gerou a colonização do imaginário desses povos. A colonização do imaginário foi feita a partir de uma repressão de todo o conhecimento, de crenças, imagens e símbolos que não fossem úteis aos padrões coloniais com uma repressão maior sobre as formas de conhecimento e sua produção. Concomitantemente foram impostas formas de produção e conhecimento nos moldes ocidentais que colaboraram como meios de controle social e cultural, especialmente 
quando a repressão direta não era mais tão frequente (OLIVEIRA, 2017, p. 25).

O resultado dessa subjugação colonial e dessas artimanhas de dominação é uma forma de "epistemicídio", no qual o extermínio de pessoas não é necessário a alma é subjugada, ou seja, o conhecimento é colonizado

\begin{abstract}
Assim, o padrão ocidental de conhecimento torna-se universal e influi de forma diferenciada de acordo com cada região. Essas destruições do imaginário e das formas de produção de conhecimento caracterizam o epistemicídio na medida em que não é necessário que haja o extermínio de pessoas para que haja o extermínio do conhecimento ${ }^{31}$ (OLIVEIRA, 2017, p. 25).
\end{abstract}

A resistência aos padrões de extermínio impostos pelos colonizadores aos colonizados no Brasil não auferiu uma vitória esmagadora e definitiva, pois, ao resistirem os padrões culturais e religiosos dos dominados, no caso indígenas e africanos, verifica-se uma luta que não cessa. O que gerou a confecção dessa proposta de trabalho, a resistência das religiões afro-brasileiras, diante a ferocidade e das demonstrações de poder ilimitados daqueles que desferem os ataques e a permanência das expressões religiosas de comunidades tradicionais de terreiro, mesmo com todo poder e da histórica desigualdade dos dominantes e dos dominados, como atesta a autora, que citará Segato e Bhabha, nessas permanências de padrões culturais e religiosas, mesmo com a força e a brutalidade do racismo

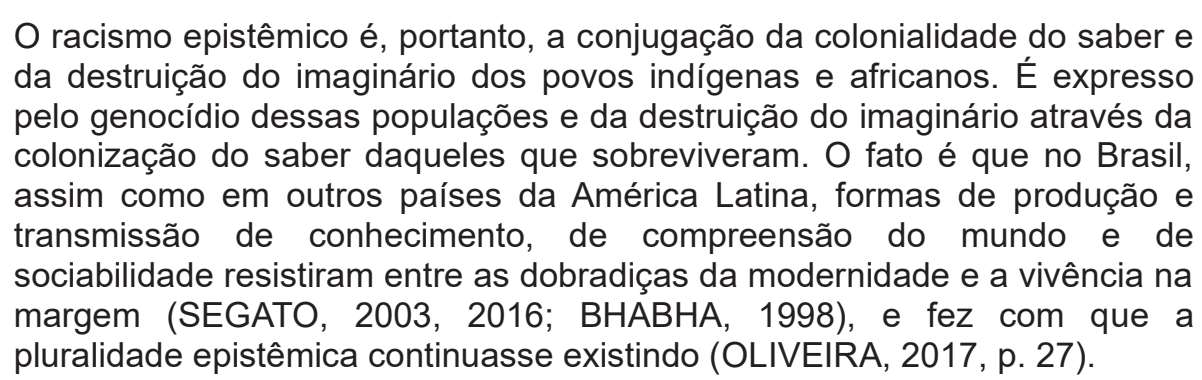

\footnotetext{
31 Sobre a categoria de epistemicídio ver: De Sousa Santos, Boaventura. 2010. Una Epistemología del sur. México: Siglo XXI.
} 
O colonialismo provocou e provoca diversas mazelas nas sociedades dominadas pelas formas de subordinação do ser e do saber atreladas ao eurocentrismo, que destruía e destrói tudo que não esteja relacionado ao padrão Europeu de poder que tem no racismo a sua base de sustentação e orientação. Como afirma Oliveira

Com a continuidade do padrão colonial de poder e sua projeção global, o racismo, como seu eixo estruturante, continua a existir e violar os povos e comunidades que possuem outras formas de saber, ser, de conviver e comercializar que não as ocidentais. Essa é a realidade em que vivenciam as religiões afro-brasileiras distribuídas em suas comunidades de terreiro pelo Brasil. São vítimas do racismo que embasa as violações, a discriminação, os ataques, as criminalizações e os preconceitos contra essas religiões (OLIVEIRA, 2017, p. 27).

Os ataques aos praticantes das religiões de comunidades tradicionais de terreiro e a destruição de seus símbolos e/ou de terreiros e os seus pertences sagrados tipificam uma continuidade do genocídio do negro brasileiro e de suas formas religiosas e de seus saberes e conhecimentos sagrados. Essa destruição tem por objetivo purificar o Brasil dos elementos que, de acordo com seus perseguidores, atrapalham o país rumo ao futuro cristão. Como demonstra a autora da dissertação sobre o racismo religioso, citando Rita Segato e Wanderson Flor do Nascimento

\begin{abstract}
A grande sacada aqui é que a questão do racismo epistêmico extrapolar os limites raciais estabelecidos pela cor da pele e findar por condenar à inferiorização todos aqueles e aquelas que estabelecem uma relação com o mundo a partir de um "cosmos" (SEGATO, 2016) que se difere da racionalidade-modernidade, independentemente da cor da pele (FLOR DO NASCIMENTO, 2016). Com isso, uma pessoa tida como branca socialmente, também é passível de sofrer discriminações quando se apresenta como pertencente a comunidades afro-religiosas (OLIVEIRA, 2017, p. 27).
\end{abstract}

Como constatou a autora, existe no Brasil um racismo diferenciado, isto é, o nosso racismo não é como o estadunidense. Para chegar a essa constatação, a autora utilizou como referência Oracy Nogueira, que concluiu que temos um 
"preconceito racial de marca" e não um "preconceito racial de origem", que caracteriza o racismo dos estadunidenses. Esse preconceito de marca caracterizase por "tudo aquilo que possa ser observado incluindo a aparência física, a gesticulação e o sotaque e, acrescento, qualquer outro característico cultural", conforme citou (OLIVEIRA, 2017, p. 28/29 apud NOGUEIRA, 1985. p. 31).

Ariadne Moreira Basílio de Oliveira (2017), em sua feliz constatação sobre a verdade do racismo religioso, demonstra a especificidade desses atos contra essas religiões afro-brasileiras como uma clara ação do racismo contra os fiéis independentemente da cor do fiel, ele, ao se declarar como praticante das religiões de comunidades tradicionais de terreiro, já declara a sua opção pela cultura dita inferior e demonizada pelos intolerantes e racistas que praticam os atos de violência aos terreiros e aos seguidores das religiões afro-brasileiras. Esses intolerantes foram colonizados na alma, quando a pessoa prática uma religião tendo como base o ódio e a perseguição as outras ele passa a ter a alma colonizada pelo fanatismo religioso que o transforma em mais um integrante das perseguições históricas promovidas pela Igreja Católica e o seu "Tribunal do Santo Ofício", ou seja, são inquisidores que repetem os atos de violência aos seus desafetos da fé.

Vivendo nas margens da sociedade, escondidas em residências, estrategicamente, formados, localmente, como quilombos urbanos, os terreiros, enfrentam e desafiam a ordem imposta pelo padrão do racista epistêmico, que quer subjuga-lo a aceitar a salvação dita única como resposta para todas as mazelas dos dominadores, que mesmo na atualidade, não descansa, na sua "Cruzada de imposição epistêmica", desdenhando dos saberes e das formas de resistência dos praticantes das religiões de comunidades tradicionais de terreiro, que como resposta, tímida, por sinal, cura e recebe esse "cruzadista e racista", na sua 
comorbidade e no seu momento de fraqueza, curando e reestabelecendo o seu equilíbrio. No entanto, a força do racismo e da dominação racista é uma força que derruba governos, promove guerras e elimina opositores aos seus parâmetros de dominação. A resistência é marginal e, ao mesmo tempo, permanente. Contudo, ao resistir, não há pretensões proselitistas e desejos dos padrões de dominância e de ataques como aqueles realizados pelos seus perseguidores, o que confere aos praticantes das religiões de comunidades tradicionais de terreiro, uma resistência de paz e não de guerra, a paz e o entendimento do outro como subjugado por forças incompreensíveis para aqueles que desferem os ataques racistas e extremados contra a fé dos afro-religiosos. Essa incompreensão dos demais setores, diante da tibieza da resistência afro-brasileira está na não compreensão da grandeza e da capacidade de atravessar o tempo como "quilombos da fé".

No Brasil, a ideia de miscigenação e assimilação dos negros, visando o branqueamento e a integração de sua cultura ao do nacional, demonstra a força do racismo brasileiro, que busca apagar as características negras da sua população, a autora aponta para Lélia Gonzalez, que denuncia o embranquecimento da cultura negra quando tratada como cultura popular

Isso aponta para o racismo epistêmico como uma das fortes características
do racismo no Brasil. O fato da existência de uma ideologia
miscegenacionista e do assimilacionismo expresso como uma forma de
tornar as contribuições e influências africanas como características de uma
cultura popular ou de um folclore nacional, como apontam Abdias
Nascimento (1978) e Lélia Gonzalez (1988), é característica de um racismo
epistêmico na medida em que não pode ignorar a sua existência, a assimila
retirando a sua origem negra e, coetaneamente, rechaça as diferenças
culturais expressas sob formas africanas de estruturação social. Segundo
Lélia Gonzalez (1988), as influências africanas na formação histórica -
social do Brasil tem sido negligenciadas. Ao falar das influências africanas
sobre o português brasileiro, por ela denominado "pretoguês", como sendo
um aspecto pouco explorado, ela continua: Similaridades ainda mais
evidentes são constatáveis, se o nosso olhar se volta para as músicas, as
danças, os sistemas de crença etc. Desnecessário dizer o quanto tudo isso
é encoberto pelo véu ideológico do branqueamento, é recalcado por
classificações eurocêntricas do tipo "cultura popular", "folclore nacional" etc., 
que minimizam a importância da contribuição negra (OLIVEIRA, 2017, p. 30/31 apud GONZALEZ, 1988, p. 70).

No caso apontado por Abdias do Nascimento, o branqueamento leva ao genocídio do negro no Brasil, o que podemos constatar com os números da violência contra os negros no país. A violência não é apenas física, ela busca homogeneizar a população negando a cultura de origem e massificando tudo em uma dita cultura nacional, conforme é indicado por Oliveira

Para Abdias Nascimento (1978), a ideologia do branqueamento corresponde a uma estratégia do genocídio da população negra na medida em que através do miscigenacionismo, que busca a homogeneidade da população a partir de seu branqueamento, e do consequente assimilacionismo, na medida em que na mesma medida que se quer homogeneizar a população racial quer que ela seja homogênea culturalmente (OLIVEIRA, 2017, p.31).

Oliveira aborda a questão do uso dos termos negro ou afrodescendente, como o nosso racismo não é o mesmo do estadunidense, que discrimina a origem negra, o nosso tem características de peculiaridades fenotípicas e não na origem, quanto mais traços fenotípicos, mas a pessoa tende a ser discriminada e rechaçada dos padrões racistas impostos pela sociedade embranquecida brasileira, assim afirma a autora, citando Rita Segato

Ao se referir ao uso do termo negro em detrimento do termo afrodescendente, já que a maioria da população brasileira é afrodescendente, Segato (2005) alude a uma forte característica do racismo no Brasil em que se luta para não se ver reconhecido no "outro", ou seja, não ser reconhecido como negro: Esse menosprezo das elites pode ser um efeito do racismo à brasileira, isto é, um racismo marcado pelo medo da familiaridade. O termo 'racismo' denomina e confunde, a meu ver, operações distintas de discriminação. Porque, enquanto os racismos nórdicos excluem o negro justamente por percebê-lo como um 'outro', ou seja, como alguém verdadeiramente alheio e desconhecido, entre nós o negro é discriminado e os rituais de distanciamento em relação a ele são incansavelmente encenados na vida pública justamente por uma motivação oposta: o que se teme é ser "o mesmo", o que ameaça é a possibilidade de desmascaramento da mesmidade. Portanto a exclusão do negro no Brasil é a exclusão de alguém precisamente por estar imbricado, por ser próximo e de dentro e, por isso mesmo, numa nação insegura da sua modernidade, acenar com o perigo da contaminação pelo signo da derrota histórica do povo africano e sua subsequente sujeição (OLIVEIRA, 2017, p. 31 apud SEGATO, 2005a, p. 15- 16). 
A construção do estado-nação é um problema que envolve uma reprodução do padrão europeu e, consequentemente, o desrespeito aos povos que ajudaram na implementação do Estado brasileiro, ou seja, aos nativos e aos africanos que ajudaram na formação o Brasil, assimilacionismo e invisibilidade. No entanto, a exclusão dos elementos formadores é visível no cotidiano dos brasileiros, de acordo com a autora, que cita Quijano

\begin{abstract}
A construção dos Estados-nação nos países na América Latina foi colocada como uma mera reprodução do desenvolvido na Europa, configurando-se um padrão de homogeneidade social que não corresponde com a composição diversa das sociedades aqui presentes, sociedades marcadas, portanto, pela racialização e pelo colonialismo. Os grupos dominantes desses países estavam interessados na nacionalização, mas sem querer abrir mão do compartilhamento do poder com os demais segmentos sociais, o que impossibilitou a real nacionalização desses territórios (OLIVEIRA, 2017, p. 32 apud QUIJANO, 2014a).
\end{abstract}

O branqueamento e a branquitude da elite nacional configuraram como meta dessa camada dirigente, que segundo Oliveira, é insegura de sua brancura devido a elevada miscigenação da sociedade brasileira, a descendência de europeus, africanos e indígenas é visível em nossa formação social. Porém, para permanecer com esses projetos o racismo e a colonialidade do poder e do saber permanecem como forma de afastamento e de exclusão da maioria da população de instrumentos necessários para uma vida digna e cidadã. Para ajudar no branqueamento da sociedade, foram incentivadas as imigrações de populações que diferenciassem do nativo e do africano, teóricos racistas afirmavam que a mistura com os elementos brancos trazidos, preferencialmente da Europa, proporcionaria a evolução para um padrão civilizacional europeu.

Esteticamente confusa e receosa de sua branquitude, essa elite, enojada do povo, buscava uma solução para os problemas nacionais através de teorias racistas 
e assimilacionistas que buscavam homogeneizar e padronizar os tipos físicos, através da eliminação de nativos e de africanos.

A justificativa para a política do branqueamento teve a participação de intelectuais brasileiros na construção de uma nação que evoluía aos patamares do padrão europeu. Esse processo, de acordo com esses teóricos, deveria durar um século ou menos para uniformizar a população brasileira ao padrão europeu. A maioria desses intelectuais acreditavam que nativos e negros eram inferiores e que os mestiços carregavam a degenerescência de padrões raciais inferiores. Assim, a justificativa para a continuidade do racismo no Brasil está na manutenção da colonialidade do poder, como afirma a autora, na condução da ideologia de branqueamento

\begin{abstract}
A construção da ideologia de branqueamento foi, portanto, uma estratégia conscientemente tomada pela elite que governava com o intuito de permanecer nas referências forjadas a partir da conquista e da colonização das Américas pelos europeus, já que essa elite se percebe como herdeira da branquitude e seus ideias dando continuidade assim, apesar da independência do Brasil de Portugal, a colonialidade do poder e a exterioridade do governo com relação à população brasileira (OLIVEIRA, 2017, p. 33).
\end{abstract}

A nacionalidade brasileira, para a maioria dos intelectuais brasileiros, após o abolicionismo, seguiu tendências europeias, mas desenvolveu lógicas originais e, de acordo com a autora, diversos autores inferiorizavam os negros e indígenas e acreditavam na incapacidade do mestiço de melhorar a nação (OLIVEIRA, 2017, p. 34/35).

Autores com Alberto Torres e Manuel Bonfim não abordavam uma visão exclusivamente racista, mas desejavam uma padronização social atrelada ao higienismo e intervenção autoritária nos campos político e cultural. Desejavam uma 
educação enquadrada ao evolucionismo moderno, desviando o critério racial para o cultural, justificando e fortalecendo o racismo epistêmico (OLIVEIRA, 2017, p. 35).

Os demais pensadores defendiam a degenerescência do mestiço e do negro para o projeto de formação da nacionalidade e todos esses intelectuais ganharam destaque para a ciência e política do período inicial da República. Sílvio Romero acreditava na predominância biológica e cultural do branco sobre indígenas e negros e a consequente homogeneização social após um período entre seis e sete séculos, conforme a autora que citou Munanga (2006) e Nascimento (1978).

Já João Batista Lacerda, de acordo com Oliveira (2017), acreditava na inexistência de negros, índios e mestiços num período de um século. Este acreditava na miscigenação imediata e instantânea dada a crença na predominância da superioridade do branco sobre as demais raças. Enquanto aquele, dada a uma temporalidade maior do processo de branqueamento, recebeu muitas críticas.

O pesquisador Raymundo Nina Rodrigues era defensor de um purismo e acreditava que o mestiço herdava os problemas da raça inferior. O negro, de acordo com Rodrigues, era atrasado em relação ao europeu, logo o mestiço, sofreria problemas ao ter contato com "espíritos atrasados" e, ainda, propõe uma "responsabilidade penal atenuada" devido as diferenças entre negros, brancos e mestiços, no que transforma Rodrigues em um defensor da pureza nagô, devido à complexidade da organização ritual elaborada dos iorubanos, de acordo com Munanga (2006), ao ser citado pela autora em questão (OLIVEIRA, 2017, p. 36 apud MUNANGA, 2006). Para Rodrigues os Bantos não traziam a preservação de sua língua e a sua cultura, com isso havia uma classificação e hierarquização dos negros que foram forçados a vir para o Brasil, conforme as teorias de Nina Rodrigues. 
A miscigenação não produziria um tipo racial único, como defendido pôr em contrapartida por Sílvio Romero. Neste caso, Euclides da Cunha não acreditava em uma homogeneização racial defendida por Romero, daí a crença em uma instabilidade do mestiço que oscilaria entre as características do branco e do negro. A partir dessa defesa, Euclides não dava ao Brasil uma condição de nação, principalmente, pelo resultado dessa mistura que levava aos graves problemas nacionais.

João Batista Lacerda considerava os mestiços seres intermediários entre o negro e o branco. Apostava no fim da raça negra, com a relação de brancas e mulatos.

Oliveira Vianna destaca-se como o principal representante da ideologia do branqueamento. Traz uma divisão entre mulatos inferior e superior e que estes eram superiores ao mestiço do branco com índio, por considerá-lo com um físico fraco. Os mulatos superiores auxiliariam num remoto branqueamento da população brasileira, o mestiço estaria, segundo Vianna, mais próximo do branco ou do negro. De acordo com a autora, que obteve essas informações com Munanga (2006) (OLIVEIRA, 2017, p. 37 apud MUNANGA, 2006).

De acordo com Oracy Nogueira, Vianna promoveu o protagonismo do branqueamento como ideologia e confirma o tipo de racismo característico do Brasil, o preconceito de marca, ou seja, a aparência de negro é o que caracteriza o racismo do brasileiro, quanto mais negroide mais sofrerá com o racismo que é uma desclassificação da pessoa, do cidadão pela sua cor.

A autora cita Munanga (2006), que compreende a miscigenação como uma estratégia da elite governante de tirar a superioridade numérica do povo negro e dar 
aos mestiços participação na sociedade em construção, permitindo a incorporação dos mestiços aos valores eurocêntricos.

Após a República Velha, as mudanças políticas levam a preocupação com o social e não continuar na lamúria dos teóricos raciais. Mas a interpretação da questão racial sofre uma mudança significativa, pois o foco não seria mais a raça e sim a cultura, com as propostas de Gilberto Freyre. Neste caso, a ideologia do branqueamento não suporta a montagem da identidade nacional do desenvolvimento da nação com relações não conflituosas entre as raças, isto é, o mito da democracia racial. Freyre não evidencia os conflitos e traz romance e amenidades nas relações raciais no Brasil, ou seja, as escravizadas gostavam de seus senhores, daí o surgimento dos mestiços, uma imitação do paraíso na terra devido a bondade dos portugueses, conforme Oliveira, que cita Munanga (2006) (OLIVEIRA, 2017, p. 38 apud MUNANGA, 2006).

Cabe ressaltar que a cultura ideal não é a do negro e, muito menos, a do indígena, a cultura que prevalece nesse destaque cultural é portuguesa. E, para evidenciar o epistemicídio, a cultura nacional absorve a contribuição de negros e índios para a formação da nação, conforme Oliveira (2017), citando Munanga (2006).

Já para Abdias Nascimento, todo esse processo de branqueamento faz parte de um planejado genocídio da população negra no Brasil. O branqueamento segue um padrão de colonialidade das elites que querem permanecer no poder seguindo os padrões impostos pelos colonizadores portugueses.

Oliveira passa a considerar a tolerância como uma criação, após as disputas entre reformistas e contrarreformistas na Europa (OLIVEIRA, 2017, p. 39). A religião dos europeus, após a Reforma Protestante, passa a depender da autoridade secular 
para ser estabelecida como religião hegemônica. Isso leva a disputas e guerras pelo poder político e ao mesmo tempo religioso. Onde Weber (1967) sintetiza: "A reforma queria, portanto, apenas substituir o poder da Igreja Católica pelo clero, também estruturado e hierárquico, das igrejas protestantes. No fundo os reformistas desejavam o poder da imposição de suas doutrinas esmagando os dissidentes ou movimentos contra hegemônicos dentro do Estado (OLIVEIRA, 2017, p. 40).

Mesmo com as repressões, alguns grupos dissidentes se sobressaíram e passaram a ter muitos seguidores que não poderiam passar por um processo repressivo sem uma alteração das regras sociais. A partir desse impasse surge a tolerância religiosa, desde que, o grupo hegemônico não fosse ameaçado. Buscavase trazer a paz interna da nação e expandir para a colonização de territórios ultramarinos. De acordo com Dussel (2004):

O conceito de tolerância foi historicamente impulsionado no contexto da discussão sobre liberdade religiosa pelo iluminismo moderno, como uma forma de afirmação de direitos subjetivos.

Surgem, a partir dessa política de tolerância, duas situações: uma hegemônica, que tolera, e uma não hegemônica, que é tolerada. No que Dussel (2004) afirma:

Tolerar não compreende ou envolve o respeito pelo outro, mas sim uma permissão de sua existência tutelada, que está sempre limitada à vontade e interesse da imposição hegemônica na medida em que não a ameaça.

Já a intolerância religiosa é o não reconhecimento ou não acatamento da religião não hegemônica, isso resultou em perseguições dos inquisidores católicos na Idade Média e na condução da Reforma Católica.

Oliveira considera a prática da intolerância como algo que o Estado busca isentar-se associando o ato intolerante aos episódios de cunho individual daquele 
que faz determinada ação de intolerância (OLIVEIRA, 2017, p. 42). A lógica dos direitos humanos, de acordo com a autora, busca individualizar e responsabilizar o indivíduo pelos desvios cometidos nos atos intolerantes. O que ela concebe é que atitudes intolerantes e discriminação religiosa podem ter uma base estrutural na sociedade e não apenas o reflexo de atitudes isoladas por pessoas ou pequenos grupos religiosos contra outros. Ela busca em Blancarte (2003) a razão para o antissemitismo ser mais complexo do que uma simples discriminação religiosa, ou seja, a autora vê uma possibilidade de interpretação além da intolerância religiosa. Nisso Oliveira é categórica ao informar que o termo "intolerância religiosa" não é o suficiente para demonstrar os momentos críticos que as religiões afro-brasileiras sofreram durante a sua trajetória histórica no Brasil (OLIVEIRA, 2017, p. 43).

Oliveira (2017) destaca o valor das comunidades tradicionais afro-religiosas como resistência à colonização e à colonialidade, por preservarem os saberes espirituais oriundos do continente africano. Lembra que as violações aos terreiros refletem o racismo dada ao tratamento desumanizado e ojeriza que os racistas têm da forma como essas religiões se manifestam, demonizando-as e ridicularizando-as, tudo com a total falta de interesse do Estado em resolver o problema. A autora lembra que a existência da Lei Caó (Lei 7716/89), tem como tipificação o crime de racismo. Mas, na maioria dos casos de racismo ocorre o enquadramento em "injúria racial", que diminui o ato racista a uma ofensa com baixo teor penal para o racista, demonstrando a estrutura racista de nossa sociedade.

Em sua argumentação, Oliveira destaca que o racismo religioso é mais completo que a intolerância religiosa por evidenciar as perseguições que essas religiões têm sofrido e sofrem e que são encaradas pela Justiça como injuria racial, o 
que não é um fato isolado e sim todo um sistema que desclassifica o povo de santo e suas práticas religiosas (OLIVEIRA, 2017, p. 44).

A autora afirma que o Estado participa da estrutura, que privilegia uma sociedade racista e que não considera as religiões de comunidades tradicionais de terreiro como religiões, no máximo seitas e que os ataques sofridos são apenas casos isolados ou ações extremadas de fundamentalistas religiosos. Os mandantes das ações intolerantes calcadas no racismo religioso não são incomodados pela justiça e muito menos respondem, juridicamente, pelas ordens dadas aos seus fiéis durante suas práticas religiosas, tudo é parte de um repertório aceito pela maioria da população e pela justiça como fé hegemônica cristã, o que está fora desse fator predominante, não é aceito como prática aceitável por Deus.

De acordo com a autora (OLIVEIRA, 2017, p. 45 apud DO NASCIMENTO, 2016), os elementos africanos presentes nas religiões de comunidades tradicionais de terreiro provocam as reações racistas daqueles que sequer entendem ou menosprezam os rituais, e não só a questão religiosa, toda a organização de uma comunidade de terreiro que foge dos valores aceitos em uma sociedade embranquecida e que não respeita a forma africanizada das comunidades tradicionais de terreiro. Daí a defesa da autora para o racismo religioso, dado o desrespeito e o aviltamento das comunidades e das mortes, agressões e destruição de objetos pertencentes ao espaço físico dos terreiros.

O racismo no Brasil tem peculiaridades que não são explicitadas e formou o mito da democracia racial algo muito desejado pelos ideólogos do branqueamento. No entanto, esse racismo expressa através da assimilação e absorção do negro, ao mesmo tempo que rejeita através da discriminação, miscigena e dissolve as influências africanas no folclore e cultura popular homogeneizante (OLIVEIRA apud 
GONZALEZ, 1988). Outrossim, a autora confirma a diferença explicitada das religiões afro-brasileiras que tem como base influências africanas e indígenas que diferem da padronização eurocêntrica do ser movida pelos setores dominantes que inviabilizam outras leituras do mundo que não a hegemônica cristã (OLIVEIRA, 2017, p. 47).

Ao contrariarem os desejos evolucionistas e higienistas das elites branqueadas, as religiões de comunidades tradicionais de terreiro passaram pelo processo de repressão, criminalização e perseguições oficializadas pelo nascente Estado republicano brasileiro. Na atual conjuntura, a explicitação do branqueamento, não se faz com perseguições estatais, mas com o descaso, a não contemplação e respeito a religião afro-brasileira, não alcançando essa categoria no meio jurídico brasileiro. Oliveira lembra da decisão do juiz de direito Eugênio Rosa de Araújo, da $17^{\text {a }}$ Vara Federal, dando a sentença na qual não conferia as religiões de comunidades tradicionais de terreiro a consideração de religião, ocorrido no dia 28 de abri de 2014.

O posicionamento de Oliveira (2017) com relação aos atos intolerantes deixa claro que não é uma mera questão de concordar ou não com as religiões afrobrasileiras, mas sim de práticas calcadas na discriminação, criminalização, perseguição oficializada pelo Estado e declarada de grupos neopentecostais que vislumbram as religiões de comunidades tradicionais de terreiro como portadoras do mal na sociedade brasileira. Não é uma simples intolerância é racismo religioso enfatiza a autora (OLIVEIRA, 2017, p. 48).

Para Oliveira, a modernidade não alcança as concepções afro-brasileiras, que apresentam situações de não conformidade com a racionalidade excludente e 
racista que deriva do padrão europeu de pensamento hegemônico e fatalista (OLIVEIRA, 2017, p. 49).

A colonização da América Latina trouxe o proselitismo cristão calcado na contrarreforma, o patriarcado, a moral cristã, a colonização exploradora e o acúmulo de riquezas para a metrópole. A forma europeizada de pensar e de ver as colônias é uma forma padronizada e pretensamente universal baseada no dualismo e no evolucionismo, formas que desprezam o outro e coloca como parâmetro o indivíduo isolado (OLIVEIRA, 2017, apud QUIJANO).

O europeu é a referência, é o racional, o sujeito, as demais culturas são inferiores, exóticas e precisam ser estudadas. Com esta forma de pensar e agir a dominação europeia espalhou a modernidade como uma semente de inferiorização e subjugação de povos e culturas.

O colonialismo travestido de fé em uma religião universal e dominadora proporcionou a inflexibilidade com relação as religiões não-cristãs. Ao demonizar as religiões de comunidades tradicionais de terreiro, o processo de dominação colonial estava conduzindo as perseguições contra todas as manifestações religiosas que diferissem do dogmatismo cristão.

A racionalidade ocidental tem como base a separação do objeto e do sujeito na qual Descartes formulou. Isso foi resultado de um desenvolvimento da conquista das Américas, ou seja, a diferença entre dominador e dominados. Como consequência uma hierarquização com base no critério racial.

O uso da oposição e da hierarquização, a dualidade excludente que tem como mote a diferença entre corpo e razão, onde o corpo é o objeto e a razão ligada à alma pelos cristãos e ao indivíduo racional a civilização, ao qual, privou os povos 
considerados inferiores e ligados ao corpo e a natureza como seres excluídos numa relação sujeito-objeto (OLIVEIRA, 2017, p. 51 apud SABINE; QUIJANO, 2005).

A autora cita Rita Segato (2012), que entende essa separação entre razão e objeto, faceta da modernidade, como uma "lógica binária", onde o que seria imposto pela colonização teria como característica a padronização e a imposição desse modelo rechaçando e marginalizando as demais formas de ser e viver no mundo.

Oliveira, citando Quijano, evidencia o padrão de racionalidade moderna como uma negação total do "outro", ou seja, classificando com "padrão dual" de poder colonial, Quijano difere de Segato, na definição do que seria essa racionalidade moderna. Ela confirma o conceito de verdade ao qual é elucidado através desta citação

Com a racialização da população, a destruição de seus meios de produção de conhecimento e consequente colonização do imaginário que constrói uma racionalidade moderna com apreço de estruturas patriarcais e capitalistas de poder sob a égide de um estado que governa a partir da exterioridade de sua população, esse complexo formado durante o período da conquista e da colonização da América Latina, finda por interferir na percepção da história dos países que foram colonizados, impondo uma maneira de percebê-la e a admitindo como Verdade (OLIVEIRA, 2017, p. 52 apud DUSSEL, 1994; MIGNOLO, 1996; QUIJANO, 2005).

A relação patriarcal, de acordo com Oliveira (2017), pautada na base racional e moderna que opõe o sujeito/razão e o corpo/natureza, o lugar que a mulher ocupa é associada à natureza, ao corpo e ao sexo e os homens associados ao lado racional. Essa visão binária foi a base para perversidades nas colônias, o que demonstra o alto índice de violência racial e de gênero na América Latina.

A conquista colonial, para Oliveira (2017) (apud DUSSEL,1994), funcionou como uma violência de gênero, ou seja, o estupro primeiro de nativas e depois das africanas e, também, das mulheres brancas casadas com colonos era uma regra, a conquista era sinônimo de violações de todas as formas possíveis. 
As violações garantiram a formação de relações hierarquizadas e ao inferiorizar o sexo e as raças, supostamente inferiores, isso foi decisivo para acelerar as economias vinculadas ao mercado, pré-capitalistas para capitalistas, gestadas pela acumulação que foi produto de uma exploração do trabalho forçado de indígenas e africanos escravizados e da extração de produtos e bens das colônias graças a exploração exaustiva dos escravizados nas colônias (OLIVEIRA, 2017, p. 53).

A divisão racial do trabalho, conforme Oliveira (apud QUIJANO, 2005), está associado a raça e estabelecem uma relação que controla e ao mesmo tempo impede o acesso de cargos de controle ou remunerados aos nativos, escravizados e mulheres. A dominação ficava com homens brancos portugueses e espanhóis e é esse padrão de relação social que temos até o presente momento

(...) o processo de conquista e da colonização da América Latina por países europeus fez com que, a partir do eurocentrismo, da destruição dos modos de produção de conhecimento, da colonização do imaginário, da violência patriarcal, da escravidão, do capitalismo, a racional-modernidade tornou-se um eixo estruturante do padrão de poder. $E$ suas consequências prevalecem até o presente (OLIVEIRA, 2017, p. 54).

O padrão de modernidade imposto na América Latina não conseguiu e não controlará são as resistências ao poder colonial, e, Oliveira destacou a forma como as religiões de matriz africana e o "povo de santo" organizam-se diante de imposições por parte de governos e de universalidades cristãs.

O padrão ocidental de neutralidade cientifica que promove e sustenta 0 racismo epistêmico, inviabilizando conhecimentos sobre as religiões de matriz africana, a sociedade patriarcal, o padrão colonial de poder e a demonização da religiosidade afro-brasileira, que é latente na forma de demonização dos afro religiosos pela dita universalidade da matriz cristã ao qual impede outras visões 
sobre o Sagrado que não a imposição de um Deus único e que é o portador da verdade única. Mas, as comunidades organizadas localmente preservam o modo de vida de origens africanas e não foram moldadas com base nas racionalidades modernas (OLIVEIRA, 2017, p. 55 apud NASCIMENTO, 2017).

Uma comunidade de terreiro está organizada em forma doméstica na família de santo. Não é uma família patriarcal colonialista, utiliza os termos da família biológica. Contudo, a formação tem laços rituais e depende da iniciação na religião. Nesse caso, a Mãe de Santo (lalorixá) e o Pai de Santo (Babalorixá) coordenam a família com os iniciados, chamados de filhas e filhos de santo (iaôs) (OLIVEIRA, 2017, p. 56).

Segundo Oliveira, na lógica moderna com o modelo hierárquico e excludente, a família é algo privado e o espaço público propício para a política e as relações econômicas e sociais. No entanto, toda a estrutura social encontra-se nas religiões afro-brasileiras, isto é, relações econômicas, sociais, de gênero e, também, a produção e transmissão de saberes dentro de um respeito à natureza e de uma simplicidade e objetividade no relacionamento comunitário (OLIVEIRA, 2017, p. 57).

Para Oliveira, o espaço do terreiro funciona para os ritos e para a esfera social onde funcionam de maneira harmoniosa e influenciam uma à outra. No tocante ao gênero, as funções são exercidas e não existem distinções de gênero, mas não há hierarquizações entre uma lalorixá ou um Babalorixá, ambos possuem um mesmo poder. Com relação as filhas e aos filhos de santo, não há relações hierarquizadas e ambos exercem funções basilares no terreiro como limpeza de locais comuns, os banheiros e a cozinha. Devemos considerar a divisão dos cargos de ogans (cargo exclusivo para homens) e ekedis (cargo exclusivo para mulheres), mas ambos os cargos têm importância hierárquica para o terreiro, contudo são 
equivalentes. No que Oliveira (apud SEGATO, 2005): "O espaço do terreiro torna-se, portanto, o local religioso e também um locus de uma unidade social". Sobre as questões de gênero nos terreiros, Oliveira (apud SEGATO, 2005) conclui: As tarefas desenvolvidas por ambos os sexos, em seus cargos rituais, atuam de forma complementar".

O importante para o indivíduo nas religiões afro-brasileiras não é a preocupação com a salvação, ou com o pecado, ou muito menos com o que pensam a seu respeito, a pessoa deve interagir com o seu orixá.

Os orixás, de acordo com Oliveira (apud SEGATO, 2005) possuem determinadas propensões, dons e falhas, agindo com modos próprios de autoridade e ostentando habilidades especificas. As divindades ficam caracterizadas de acordo com a personalidade de cada um, caso seja masculina aspecto duro, caso seja feminina, aspecto afável. Portanto, "o orixá dita a personalidade, e não a sexualidade. Também as personalidades e a orientação sexual estão livres de determinações biológicas" (OLIVEIRA, 2017 apud SEGATO, 2003, p. 342). E, finalmente, Oliveira enfatiza que, um orixá masculino pode ser o dono de cabeça de uma mulher, assim como um orixá feminino pode ser a de um homem e essas questões não interferem na orientação sexual da pessoa. No que Segato conclui: "De fato, o santo da pessoa é independente não só do seu sexo anatômico, mas também da forma preferencial que ela expressa a sua sexualidade, isto é, da sua preferência por parceiros homo ou heterossexuais" (OLIVEIRA, 59, apud SEGATO, 2005, p. 427).

A família de santo, em sua estrutura e funcionamento no terreiro, serve de abrigo permanente ou temporário para a diversidade de público ao qual recebe, ou seja, muitos homossexuais, travestis e transexuais são amparados e refugiados nos 
terreiros após expulsões de suas respectivas famílias carnais e, obviamente, da sociedade machista, homofóbica e transfóbica brasileira (OLIVEIRA, 2017, p. 60).

A autora destaca a economia dos terreiros como uma forma potente de resistência diante da sociedade excludente capitalista, ou seja, ela enfrenta o argumento de que o candomblé seja uma religião mercantilizada devido a estudos na qual é apontada uma forma de busca do lucro, isto é, "Oro diz que o candomblé é uma religião em que os deuses são ricos e os seus adeptos são pobres e para que haja a sustentação dos rituais, haveria muita 'caridade e cooperação' dentro dos terreiros" (OLIVEIRA, 2017 apud ORO, 1999, p. 133/134). Ao justificar a partilha do axé e a fabricação e doação de muitos dos materiais necessários para o xirê, ela desmonta o argumento de pobreza do povo de santo e de riqueza dos orixás. Em outro argumento feito por Oliveira critica-se a leitura moderna da tradição dos orixás (OLIVEIRA, 2017, p. 61). Sua leitura deste aspecto moderno é feita utilizando os argumentos de Carvalho (2011) na qual as redes de solidariedade entre os membros da comunidade promovem a manutenção e ritmo da vida comunal em suas amplitudes.

Terreiro não é sinônimo de empresa é vivência comunitária, isto é, as relações não visam ao lucro e sim a manutenção dos vínculos comunitários. O que movimenta os terreiros não é o comércio e muito menos os vínculos com interesses financeiros e expansionistas econômicos. O dinamismo das trocas que geram aumento da sociabilidade e não acúmulo de capitais ou coisas, ou seja, a diferença é nítida relaciona-se nos terreiros pelas pessoas e melhoria de todos através do axé que é a força vital presente em tudo enquanto nas relações capitalistas relaciona-se em busca dos interesses cumulativos e materialistas, o ter objetos a posse é o essencial no relacionamento capitalista. (OLIVEIRA, 2017, p. 62). O axé não é 
sinônimo de acúmulo, pois é uma força vital e essa força não está disponível e não é compreensível pela lógica cartesiana. Portanto, o axé pressupõe responsabilidade e reciprocidade nas trocas que, as vezes leva o dinheiro, mas não no sentido de sujeito objeto, mas entre sujeitos, o que não contraria a dinâmica de troca que possibilita o axé, conforme Oliveira (apud DO NASCIMENTO, 2016). O senhor do mercado, ou Olojá, é o orixá regente das interações e é um Exu, este mercado é chamado por Flor do Nascimento de mercado-ojá que tem como característica principal de "um local de troca e circulação do axé, de modo a fortalecer o caráter recíproco e complementar da dinâmica do próprio axé" (DO NASCIMENTO, 2016c, p. 32). Mas, essa dinâmica pode sofrer ameaças devido à importância dada aos clientes, isto é, pessoas que buscam o auxílio de uma lalorixá ou de um Babalorixá com interesses específicos ou necessidades momentâneas, pagando pelos serviços espirituais e não estabelecendo ligações com a comunidade de terreiro (DO NASCIMENTO, Flor, 2016c, p. 63). No entanto, a relação com o cliente satisfaz necessidades financeiras da comunidade de terreiro, funcionaria como estratégia de resistência ao capitalismo, dado os gastos e a especulação imobiliária e o interesse na terra sagrada ao povo de santo como mera mercadoria a ser vendida pelos corretores imobiliários, devido ao crescimento urbano. Portanto, o dinheiro não é uma subjugação ao modo de produção capitalista é sim uma sobrevivência e manutenção da dinâmica do terreiro (DO NASCIMENTO, Flor, 2016c, p. 64). Oliveira finaliza as críticas de uma mercantilização dos terreiros e disputas entre líderes para atrair mais clientes e por consequência mais dinheiro, proposta no trabalho de Oro (1999), o que não é uma sujeição ao capital e há, na verdade, um modo diferenciado de lidar com o dinheiro e não uma dependência de inserção na economia de mercado. 
A autora defende uma economia diferenciada com base no trabalho de Jorge de Carvalho (2011) que é uma base solidária, ou seja, uma economia do axé, uma forma de resistência afro-brasileira que resulta na manutenção do povo de santo em meio as desigualdades na distribuição da renda em nosso país. Como podemos verificar

\begin{abstract}
A economia do axé é caracterizada por uma extensa rede econômica e social estruturada a partir de uma lógica de produção em pequena ou média escala que prioriza a personalização da produção, conservando, assim o axé, ou seja, a energia positiva dos objetivos e alimentos, que são fundamentais para as dinâmicas dos terreiros, criada a partir das demandas destes. "A economia do axé, fixe-se bem, não se limita ao povo de santo, mas se estende ao circuito de bens e serviços que servem as demandas dos terreiros" (DO NASCIMENTO, Flor, 2016c, p. 65/66 apud CARVALHO, 2011, p. 40)
\end{abstract}

A alimentação dentro de um terreiro não é apenas para os afro-religiosos vivos, serve aos orixás, principalmente, e aos eguns (espíritos ancestrais pertencentes a comunidade de terreiro). Daí a importância da alimentação na vida comunal dos terreiros, não se trata de relação cruel como a da produção do abate industrial, os animais abatidos nos terreiro devem ser bem tratados para serem consumidos e devem passar por rituais próprios do povo de santo, no que fica caracterizado como abate religioso e não um abate comum, é o sacrifício ritual nas religiões afro-brasileiras que causa polêmica, mas o abate da indústria da carne não sofreu processo por parte dos defensores dos direitos dos animais (OLIVEIRA, 2017, p. 66).

A confecção de objetos, a venda de acarajé e outros alimentos sagrados e a promoção de eventos públicos para arrecadar dinheiro para os terreiros. Na economia do axé não é necessário ter materiais ou bens para a execução de melhorias nos terreiros, aqueles que possuem habilidades ou boa vontade para realizar as atividades necessárias nas reformas, também, ajudam na manutenção, 
reforma e ampliação dos espaços construídos na comunidade de terreiro. A solidariedade e simplicidade do povo de santo, sempre é destacada nas atividades que combinam interação com o entorno da comunidade e a promoção de rodas de samba, feijoadas ou venda de acarajés, como destaca Oliveira (OLIVEIRA, 2017, p. $67)$.

O racismo epistêmico desvaloriza, deprecia e desestimula a produção e a formação de saberes de terreiros e que conquistem espaço e reconhecimento no meio acadêmico e intelectual. O processo de colonização do conhecimento persiste e determina que as práticas afro-brasileiras não devem ser reconhecidas como parte da construção da sociedade brasileira. Como demonstra Oliveira

\begin{abstract}
A transmissão da produção de conhecimento nas religiões afro-brasileiras está relacionada com os mitos, itãs, orikis, histórias que são passadas de forma oral e que, segundo Segato (2007b), expressam uma compreensão profunda da sociedade na qual estão imersos inclusive demonstrando uma leitura política. Todo esse arcabouço, próprio de produção e transmissão de conhecimento estão associados a compreensão de um cosmos próprio e tem como reflexo saberes próprios e a formação e atuações relacionadas a sociabilidades que se diferem da racionalidade moderna (OLIVEIRA, 2017, p. 68/69).
\end{abstract}

A autora defende que o capitalismo, ao interferir nas comunidades de terreiro, gera consequências nefastas para as tradições de terreiro verificando um processo de racismo epistêmico nessa relação desigual, onde o capitalismo mexe com as comunidades de terreiro, mas, ao contrário, não ocorre, levando a um desmerecimento das práticas comunitárias para as sociedades ocidentalizadas. Oliveira finaliza essa parte

Apesar das interações entre a racional modernidade, o capitalismo e o patriarcalismo nas comunidades de terreiros, essas ainda seguem sendo resistência a esse sistema. Não deixando de considerar que são tradições, mas isso não significa que estejam paradas no tempo, são dinâmicas, porém guardam consigo a resistência e uma outra forma de compreender e ser no mundo (OLIVEIRA, 2017, p. 69). 
Sobre a liberdade de crença e de expressão a Constituição de 1988, em seu artigo $5^{\circ}$, em seus incisos VI e VIII, e, também, o artigo $19^{\circ}$ em seu inciso I, que: garantem a liberdade, a não privação de direitos e não expressão religiosa, com a liberdade de consciência, filosófica ou política. Essa liberdade deveria objetivar o respeito e a não violência religiosa, pois o legislador deixa claro a liberdade e a não interferência por motivações religiosas. No artigo $19^{\circ}$, está claro a não interferência do Estado nas religiões e a sua respectiva ligação a religiões ou mesmo, preferências religiosas. Senão vejamos como está o texto constitucional

Art. $5^{\circ}$ Todos são iguais perante a lei, sem distinção de qualquer natureza, garantindo-se aos brasileiros e aos estrangeiros residentes no País a inviolabilidade do direito à vida, à liberdade, à igualdade, à segurança e à propriedade, nos termos seguintes:

VI - e inviolável a liberdade de consciência e de crença, sendo assegurado o livre exercício dos cultos religiosos e garantida, na forma da lei, a proteção aos locais de culto e a suas liturgias;

VIII - ninguém será privado de direitos por motivo de crença religiosa ou de convicção filosófica ou política, salvo se as invocar para eximir-se de obrigação legal a todos imposta e recusar-se a cumprir prestação alternativa, fixada em lei;

Art. 19. É vedado à União, aos Estados, ao Distrito Federal e aos Municípios:

I - estabelecer cultos religiosos ou igrejas, subvencioná-los, embaraçar-lhes o funcionamento ou manter com eles ou seus representantes relações de dependência ou aliança, ressalvada, na forma da lei, a colaboração de interesse público;

II - recusar fé aos documentos públicos;

III - criar distinções entre brasileiros ou preferências entre si.

Oliveira destaca que o Brasil é signatário de diversos tratados internacionais, como a Declaração Universal dos Direitos Humanos, a Convenção sobre os Direitos da Criança, O Pacto Internacional pelos Direitos Econômicos, Sociais e Culturais e a Convenção Americana de Direitos Humanos, que servem como garantias a liberdade religiosa e respeito à diversidade cultural (OLIVEIRA, 2017, p. 70, apud DINIZ; LIONÇO; CARRIÃO,2010).

Ao trazer que a Organização das Nações Unidas (ONU) aprovou, no dia 25 de novembro de 1981, uma Declaração sobre a Eliminação de Todas as Formas de 
Intolerância e Discriminação Fundadas na Religião ou nas Convicções, afirmando, logo no preâmbulo, que a religião ou as convicções constituem elementos fundamentais para a constituição da vida dos que professam, devendo as convicções e a liberdade de crença serem garantidas e respeitadas integralmente, Oliveira, deixa claro que o regime de tolerância religiosa e a garantia de liberdade religiosa, legalmente estabelecidas, foram colocadas e gestadas por legisladores, mas será que todas essas legislações impediram os ataques intolerantes e problemas ligados ao não respeito às liberdades de crença e convicção religiosa (OLIVEIRA, 2017 apud BLANCARTE, 2003).

Oliveira destaca o nosso precário Estado laico, pois temos: Bancada Evangélica (cristã) lutando pelos interesses desses grupos e dificultando a vida do povo votando em peso nas principais formas de prejudicar o trabalhador e o pobre na atual conjuntura. Os crucifixos pendurados e os exemplares de Bíblias em repartições públicas, demonstram a imposição hegemônica do cristianismo no Brasil. Portanto, as leis e os ordenamentos jurídicos não são suficientes para evitar a criminalização e a exclusão das religiões minoritárias que não englobam os interesses dos cristãos.

Oliveira traça um panorama histórico da criminalização de práticas e das religiões afro-brasileiras, isto é, desde o início da colonização do Brasil, os portugueses, através de normas jurídicas derivadas das Ordenações Filipinas, primeiro conjunto de normas jurídicas que regeu Portugal desde 1603 e vigorou no Brasil até 1916, com forte influência do catolicismo romano, que serviram para regulamentar a escravidão, a conversão dos cativos ao catolicismo, a adoção do nome cristão pelo escravizado recém-convertido, a proibição de manifestações coletivas dos africanos e seus descendentes e a criminalização da feitiçaria. 
Já em 1824, pelo regime do padroado, a única religião oficial era a Igreja católica apostólica romana e as demais religiões estavam livres, desde que fossem reuniões domésticos. Quaisquer manifestações públicas de outras religiões estavam enquadradas como crime no Código Criminal do Império do Brasil.

O advento da República em 1889 e a primeira constituição republicana de 1891 trazia a separação da Igreja e do Estado e o fim do regime do padroado. Contudo, na legislação criminal, isto é, o Código Penal da República (1890), previa em seus artigos 156, 157 e $158^{32}$ os crimes de prática ilegal da medicina; o espiritismo, a magia e sortilégios e o curandeirismo, respectivamente (OLIVEIRA, 2017, p. 72 apud MAGGIE, 1992; GIUMBELLI, 2008).

Pela autora a criminalização das práticas e rituais afro-brasileiros escancara uma política higienista, positivista e comteana que serviria de base para a formação do Estado republicano, onde o racismo das leis e dos discursos da época apoiavam

\footnotetext{
32 Art. 156. Exercer a medicina em qualquer dos seus ramos, a arte dentaria ou a pharmacia; praticar a homeopathia, a dosimetria, o hypnotismo ou magnetismo animal, sem estar habilitado segundo as leis e regulamentos:

Penas - de prisão cellular por um a seis mezes e multa de $100 \$$ a $500 \$ 000$.

Paragrapho unico. Pelos abusos commettidos no exercicio ilegal da medicina em geral, os seus autores soffrerão, além das penas estabelecidas, as que forem impostas aos crimes a que derem causa.

Art. 157. Praticar o espiritismo, a magia e seus sortilegios, usar de talismans e cartomancias para despertar sentimentos de odio ou amor, inculcar cura de molestias curaveis ou incuraveis, emfim, para fascinar e subjugar a credulidade publica:

Penas - de prisão cellular por um a seis mezes e multa de $100 \$$ a $500 \$ 000$.

$\S 1^{\circ} \mathrm{Si}$ por influencia, ou em consequencia de qualquer destes meios, resultar ao paciente privação, ou alteração temporaria ou permanente, das faculdades psychicas:

Penas - de prisão cellular por um a seis annos e multa de $200 \$$ a $500 \$ 000$.

$\S 2^{\circ}$ Em igual pena, e mais na de privação do exercicio da profissão por tempo igual ao da condemnação, incorrerá o medico que directamente praticar qualquer dos actos acima referidos, ou assumir a responsabilidade delles.

Art. 158. Ministrar, ou simplesmente prescrever, como meio curativo para uso interno ou externo, e sob qualquer fórma preparada, substancia de qualquer dos reinos da natureza, fazendo, ou exercendo assim, o officio do denominado curandeiro:

Penas - de prisão cellular por um a seis mezes e multa de $100 \$$ a $500 \$ 000$.

Paragrapho unico. Si o emprego de qualquer substancia resultar á pessoa privação, ou alteração temporaria ou permanente de suas faculdades psychicas ou funcções physiologicas, deformidade, ou inhabilitação do exercicio de orgão ou apparelho organico, ou, em summa, alguma enfermidade:

Penas - de prisão cellular por um a seis annos e multa de $200 \$$ a $500 \$ 000$.

Si resultar a morte: Pena - de prisão cellular por seis a vinte e quatro annos.
} 
as práticas limpas cristianizadas e eurocentradas, ou seja, separar as práticas religiosas reconhecidas pelo Estado das que deveriam ser criminalizadas e evitadas.

O Código Penal de $1940^{33}$, de acordo com Oliveira, herdou dispositivos da legislação anterior criminalizando o charlatanismo e o curandeirismo. (OLIVEIRA, 2017, p. 74). Além da manutenção dessas leis racistas, a autora, cita os casos de registros dos terreiros em delegacias de polícias, a criminalização dos sacrifícios de animais, a lei do silêncio e a falta de regularização imobiliária de muitos terreiros (OLIVEIRA, 2017, p. 75).

No seu trabalho, Oliveira discute, o papel da mídia na imposição de uma religiosidade europeizada e representando as opiniões dos grupos dominantes. Nesses periódicos não faltam racismos, higienismos e demonização das religiões afro-brasileiras, no passado e na atualidade com as mídias nas mãos dos grandes grupos religiosos detentores do poder político e midiático, onde as perseguições as religiões afro-brasileiras são constantes.

Ela aborda o contexto das escolas como uma iniciação das práticas racistas da sociedade embranquecida e colonialista brasileira. A obrigatoriedade do ensino religioso, segundo Oliveira, aumenta a discriminação. As crianças adeptas do Candomblé e da Umbanda, escondem as suas para não sofrer bullying ou melhor racismo religioso, quando, em muitos casos, os ataques são orquestrados pelos que deveriam ensinar a não proliferação do racismo religioso e evitar o proselitismo

\footnotetext{
${ }^{33}$ Charlatanismo Art. 283 - Inculcar ou anunciar cura por meio secreto ou infalível: Pena - detenção, de três meses a um ano, e multa. Curandeirismo Art. 284 - Exercer o curandeirismo:

I - prescrevendo, ministrando ou aplicando, habitualmente, qualquer substância;

II - usando gestos, palavras ou qualquer outro meio;

III - fazendo diagnósticos:

Pena - detenção, de seis meses a dois anos.

Parágrafo único - Se o crime é praticado mediante remuneração, o agente fica também sujeito à multa.

Forma qualificada Art. 285 - Aplica-se o disposto no art. 258 aos crimes previstos neste Capítulo, salvo quanto ao definido no art. 267.
} 
cristão em seus locais de trabalho. A religiosidade afro-brasileira é um espaço onde a diferença não é rejeitada aprendemos a lidar com os diferentes em seus espaços de tradições e ao mesmo tempo de inovações para muitos aprende a lidar com a diversidade (OLIVEIRA, 2017, p. 82 apud QUINTANA, 2013).

Para Oliveira, os ataques neopentecostais crescem já na década de 1980, a discriminação ocorre nas expressões religiosas e no discurso proselitista da "Batalha Espiritual", uma polarização entre o bem (Deus) contra o mal (diabo) (OLIVEIRA, 2017, p. 82). A guerra santa dos neopentecostais é uma demonstração clara do racismo religioso presente no proselitismo das igrejas neopentecostais, principalmente na Igreja Universal do Reino de Deus (IURD), essa denominação religiosa resgata o branqueamento, higienismo e um argumento teológico central na ideia luta de um Deus cristão em evidente oposição as religiões de comunidades tradicionais de terreiro (OLIVEIRA, 2017, p. 84 apud PETEAN, 2011).

Oliveira refere essa base de construção das religiões neopentecostais de preconceito as religiões afro-brasileiras como uma ligação uma visão hierarquizada da sociedade em que os praticantes das religiões e todo o universo afro-brasileiro como inimigos da ordem e fazedores de males para a nação. Isso tudo, com o papel omisso do Estado diante dos atos intolerantes e do discurso religioso belicista e demonizador das religiões de matriz africana (OLIVEIRA, 2017, p. 85).

A autora, que é candomblecista da região do Distrito Federal e entorno, percebeu que após diversos ataques o povo de santo do qual pertencia discutia sobre o casos e não eram conversas animadoras, o clima era tenso, contudo a esperança e a fé nos orixás permitia uma reação diante das ocorrências, de roubo, destruição, incêndio e omissão por parte das autoridades que tentaram acobertar um 
ataque forjando o laudo da perícia como fogo por curto circuito, o que foi contestado pelos afro religiosos (OLIVEIRA, 2017, p. 87/88).

O descaso das autoridades policiais diante dos ataques reflete a faceta cruel do racismo religioso, onde para esses agentes o terreiro violado não é um crime como roubo ou homicídio, porém, para o povo um terreiro não é um lugar qualquer, é um local sagrado é um espaço de convivência e de vida para os praticantes, um atentado a uma terra sagrada para os seus praticantes é uma cena muito traumática para eles.

A Lei Caó ${ }^{34}$, que trata dos crimes resultantes de discriminação ou preconceito, denuncia a inoperância da sociedade embranquecida em aplicar a lei. Após os

\footnotetext{
${ }^{34}$ LEI N ${ }^{\text {o }}$ 7.716, DE 5 DE JANEIRO DE 1989

Define os crimes resultantes de preconceito de raça ou de cor.

Faço saber que o Congresso Nacional decreta e eu sanciono a seguinte Lei:

Art. $1^{\circ}$ Serão punidos, na forma desta Lei, os crimes resultantes de preconceitos de raça ou de cor.
}

Art. $2^{\circ}$ (VETADO).

Art. $3^{\circ}$ Impedir ou obstar o acesso de alguém, devidamente habilitado, a qualquer cargo da Administração Direta ou Indireta, bem como das concessionárias de serviços públicos.

Pena: reclusão de dois a cinco anos.Art. $4^{\circ}$ Negar ou obstar emprego em empresa privada.

Pena: reclusão de dois a cinco anos.Art. $5^{\circ}$ Recusar ou impedir acesso a estabelecimento comercial, negando-se a servir, atender ou receber cliente ou comprador.

Pena: reclusão de um a três anos.Art. $6^{\circ}$ Recusar, negar ou impedir a inscrição ou ingresso de aluno em estabelecimento de ensino público ou privado de qualquer grau.

Pena: reclusão de três a cinco anos. Parágrafo único. Se o crime for praticado contra menor de dezoito anos a pena é agravada de $1 / 3$ (um terço).

Art. $7^{\circ}$ Impedir o acesso ou recusar hospedagem em hotel, pensão, estalagem, ou qualquer estabelecimento similar.

Pena: reclusão de três a cinco anos. Art. $8^{\circ}$ Impedir o acesso ou recusar atendimento em restaurantes, bares, confeitarias, ou locais semelhantes abertos ao público.

Pena: reclusão de um a três anos.Art. $9^{\circ}$ Impedir o acesso ou recusar atendimento em estabelecimentos esportivos, casas de diversões, ou clubes sociais abertos ao público.

Pena: reclusão de um a três anos.Art. 10. Impedir o acesso ou recusar atendimento em salões de cabeleireiros, barbearias, termas ou casas de massagem ou estabelecimento com as mesmas finalidades.

Pena: reclusão de um a três anos.Art. 11. Impedir o acesso às entradas sociais em edifícios públicos ou residenciais e elevadores ou escada de acesso aos mesmos:

Pena: reclusão de um a três anos.Art. 12. Impedir o acesso ou uso de transportes públicos, como aviões, navios, barcas, barcos, ônibus, trens, metrô ou qualquer outro meio de transporte concedido.

Pena: reclusão de um a três anos.Art. 13. Impedir ou obstar o acesso de alguém ao serviço em qualquer ramo das Forças Armadas.

Pena: reclusão de dois a quatro anos.Art. 14. Impedir ou obstar, por qualquer meio ou forma, o casamento ou convivência familiar e social.

Pena: reclusão de dois a quatro anos.Art. 15. (VETADO).

Art. 16. Constitui efeito da condenação a perda do cargo ou função pública, para o servidor público, e a suspensão do funcionamento do estabelecimento particular por prazo não superior a três meses.

Art. 17. (VETADO). 
ataques aos terreiros no Distrito Federal e entornos, audiências públicas foram realizadas e até um lançamento de uma frente parlamentar dos povos de comunidades tradicionais de terreiro, ao qual Oliveira participou. Nos eventos instituições como a Fundação Palmares e a extinta Secretaria de Promoção da Igualdade Racial (SEPPIR) auxiliaram as comunidades de terreiros que sofreram os ataques. Contudo, as mudanças conjunturais e a falta de políticas de diálogo e ajuda aos povos de terreiros passaram a não existir e não funcionar, no que a autora conclui, o Estado não é um aliado das comunidades de terreiro. Ao contrário, ajuda nos ataques. O Estado promove o racismo religioso via racismo institucional (OLIVEIRA, 2017, p. 90 apud SEGATO, 2007b).

Os ataques não cessaram as atividades das religiões de comunidades tradicionais de terreiro, muitas comunidades resistem e (re)existem, lutaram e continuam lutando com simplicidade e solidariedade, o que faz uma história de luta e resistência mesmo contra uma sociedade regida pelo racismo e estruturada pelo poder colonialista.

As lutas das comunidades de terreiro proporcionaram em conjunto com os movimentos sociais conquistas no âmbito jurídico, a Lei Caó, o racismo como crime inafiançável; a Lei 10.639/03, que tornou obrigatório o ensino de história e cultura africana e afro-brasileira nas escolas públicas e privadas. E a Lei 11.645/08, que inclui a obrigatoriedade do ensino de história e culturas indígenas, demonstra a importância da contribuição deles para a construção da sociedade no Brasil.

Art. 18. Os efeitos de que tratam os arts. 16 e 17 desta Lei não são automáticos, devendo ser motivadamente declarados na sentença.

Art. 19. (VETADO).

Art. 20. Esta Lei entra em vigor na data de sua publicação.

Art. 21. Revogam-se as disposições em contrário. 
O dia 21 de janeiro, o dia de combate à intolerância religiosa, é uma data que nasceu do luto e da resistência do povo de santo diante das perseguições de seus principais algozes, os terroristas da IURD. Nessa mesma data, 21 de janeiro de 2000, ocorreu o falecimento de Mãe Gilda, do terreiro de Salvador na Bahia, llê Axé Abassá de Ogum, vítima do racismo religioso perpetrado pela IURD. Imagens da religiosa foram usadas no jornal da IURD com o anúncio: "Macumbeiros charlatões lesam o bolso e a vida dos clientes", essa publicação ocorreu em outubro de 1999. A religiosa teve acesso ao jornal e a comunidade, também, o que trouxe transtornos para a mãe de santo (OLIVEIRA, 2017, p. 91). A filha e herdeira Mãe Jaciara de Oxum, associou o episódio de racismo aos problemas e a consequente morte de sua mãe. O caso foi levado para justiça baiana e, no dia 06 de julho de 2005, o Tribunal de Justiça da Bahia condenou a IURD à indenização por danos morais a família de mãe Gilda. Uma vitória da resistência do povo de santo diante do poder dos conglomerados da fé proselitista da IURD. Oliveira destaca, também, a luta contra os que condenam os abates nas religiões afro-brasileiras para defesa dos animais e o mesmo mote de defender as frágeis criaturas não é usado contra a famigerada indústria da carne e a crueldade na busca do lucro a qualquer custo, é racismo essa pretensa defesa dos animais feita de maneira seletiva e não total (OLIVEIRA, 2017, p. 92).

A autora acredita na possibilidade de um incremento nos trabalhos sobre o racismo religioso com novas pesquisas

A própria questão basilar do racismo religioso, que é o racismo na sociedade brasileira, pode e deve ser mais aprofundada tendo em vista a complexidade de sua estrutura e das formas negativas, discriminatórias e prejudiciais que afetam a construção de uma sociedade onde haja além do direito o real respeito ao outro (OLIVEIRA, 2017, p. 93). 
Oliveira, finalmente, reflete sobre a necessidade de estudar as comunidades de terreiros e as religiões afro-brasileiras, não com olhares cartesianos, e sim com um olhar decolonial:

A realidade é que as tentativas de tradução dessas comunidades em termos da racionalidade moderna não são possíveis. Trata-se de outra coisa, de outro modo, outra compreensão. E por se tratar de outro cosmos é que essas comunidades são discriminadas e sofrem tentativas de destruição diárias com violências racistas simbólicas e físicas (OLIVEIRA, 2017, p. 94).

\section{OBSERVAÇÃO DO CAMPO RELIGIOSO E ENTREVISTAS}

As visitas aos terreiros e locais de reuniões de umbandistas e de candomblecistas passaram a ser o objetivo. Inicialmente, foram realizadas visitas para o conhecimento e o reconhecimento do campo religioso afro-brasileiro da cidade de Juiz de Fora. Devido às contingências de deslocamento, não foi possível conhecer muitos terreiros, não atendendo à orientação para visitar o máximo de locais possíveis.

Após as visitas, com o reconhecimento e a permanência no local, foram realizadas entrevistas com integrantes e frequentadores de religiões de comunidades tradicionais de terreiros. De forma a manter o anonimato das informações cedidas, os nomes dos entrevistados foram mantidos sob sigilo no presente trabalho. Assim os entrevistados serão tratados aqui como A, B, C, D, E F, G, H, I, J, K, L e M.

O roteiro utilizado para as entrevistas foi padronizado, minuciosamente elaborado e simplificado para orientar na transcrição de objetivos da pesquisa e está dividido em duas partes: uma relacionada aos dados pessoais do entrevistado, e a outra, contendo questionamentos sobre a intolerância religiosa. Neste roteiro, o entrevistado poderia fazer um breve relato de sua vivência na religião, destacando 
questões como os problemas ligados a intolerância religiosa, atitudes tomadas frente aos ataques intolerantes, discussão do tema dentro dos grupos e principais os setores que poderiam desferir os ataques intolerantes. Com relação a organizações de defesa do povo de santo, as indagações foram sobre o conhecimento e existência de determinados grupos na cidade, no Estado e no Brasil.

A ajuda do Comitê de Ética em pesquisas humanas da Universidade Federal de Juiz de Fora colaborou com o concurso das entrevistas e na simplicidade dela, pois ao lidarmos com o campo afro-brasileiro devemos ser objetivos e claros em nossas propostas. Essa forma de abordar e realizar entrevistas nesse campo religioso requer do entrevistador uma observação maior do local dos rituais. Se possível, não devem ser utilizados anotações e gravadores. O uso destes recursos deve ser autorizado pelos entrevistados, o que na maioria das vezes, não foi permitido. Daí uma boa dose de observação e conhecimento prévio do campo de trabalho e de utilização de conversas para adentrar melhor no cotidiano da casa ou do terreiro em questão.

Os questionários foram respondidos por entrevistas face a face ou remotas, sendo enviados àqueles que se dispuseram a respondê-lo, podendo ser respondidos de forma escrita ou oral. A necessidade de realizar a pesquisa proporcionou uma mudança na utilização dos meios eletrônicos para a realização das entrevistas. Os questionários respondidos por escrito, foram reenviados ao pesquisador por e-mail ou foram respondidos por aplicativos, como Instagram e Messenger. Aqueles respondidos oralmente, tiveram suas respostas por telefonema ou enviadas em arquivos de áudio pelo aplicativo de mensagem WhatsApp, sendo posteriormente transcritos para arquivos de texto. Como desvantagem, muitos solicitados não 
responderam à entrevista, com as mensagens não passando de um monólogo por parte do pesquisador.

As pesquisas usando meios eletrônicos repercutiram e a obtenção de respostas vem crescendo a cada dia que passa. Assim um banco de dados sobre intolerância vem sendo realizado por meios que surgiram como alternativa, mas que poderão resultar em mais informações para estes e outros esforços para registrar a intolerância ou racismo religioso no Brasil. Talvez uma organização em defesa do povo de santo com o auxílio dessas ferramentas não teria uma forma de registrar e arquivar esses dados para futuras pesquisas utilizando essa temática do desrespeito a religiosidade de comunidades tradicionais de terreiro.

Ao todo, foram entrevistadas 11 pessoas, com idades entre 32 e 76 anos e alta escolaridade, como Ensino Médio, Superior Completo e Pós-graduação Latu Sensu. Os terreiros frequentados por eles estavam localizados nas cidades de Belo Horizonte (MG), Juiz de Fora (MG), Rio Novo (MG), Rio de Janeiro (RJ), São Paulo (SP) e Embu das Artes (SP), existindo há, no mínimo 2 anos. O terreiro mais antigo existe há 52 anos.

Quanto à filiação, os entrevistados afirmaram ocupar diferentes posições, como médium, ogã e babalorixá. Os entrevistados classificam seu tipo de filiação, identificando suas posições. O entrevistado A se coloca como "liderança de terreiro babalorixá" (ENTREVISTADO A, 2020) e o entrevistado B, como "Ogã. Médium são os que incorporam entidades. Ogãs e Ekedges não incorporam" (Entrevistado B, 2020).

Os entrevistados apresentaram tempo mínimo de 2 e máximo de 33 anos de filiação ao terreiro que frequentam. O tempo de filiação nem sempre coincide com o tempo de prática na religião, como relatado pelo entrevistado A, que diz estar filiado 
há "três anos. No total tenho dez anos de iniciado no candomblé de nação Ketu" (ENTREVISTADO E). O entrevistado B afirma ter mudado de terreiro desde o início de sua prática

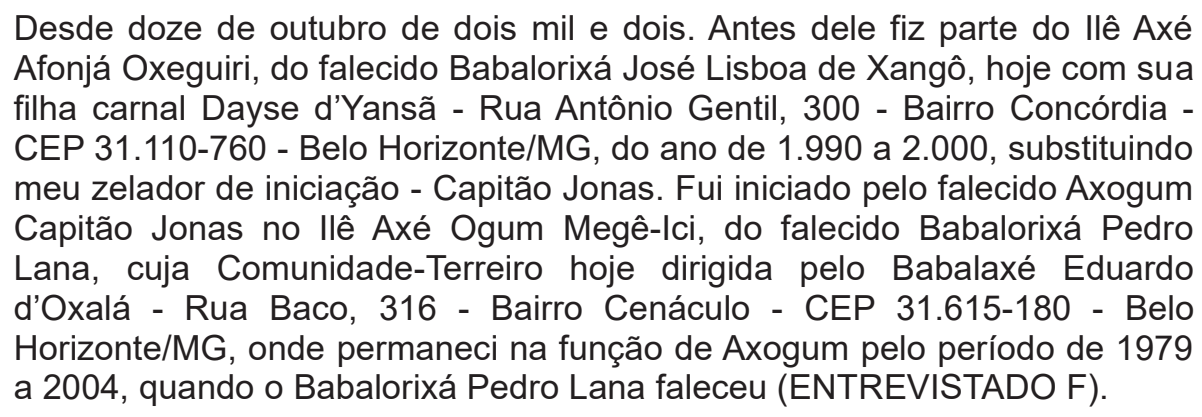

Quanto à pesquisa de campo, foram visitados quatro locais da religião de Umbanda, sendo dois na região central da cidade; e três próximos à Universidade Federal de Juiz de Fora (UFJF) - dois no Bairro Dom Bosco e um no Bairro Jardim Casablanca. Também foram visitados dois terreiros de Candomblé ou Cruzados, pois têm o funcionamento de alguns dias da semana dedicado as cerimônias de Umbanda. Um deles está localizado em Igrejinha, e atua como referência para pesquisas universitárias sobre as religiões de comunidades tradicionais de terreiro. O outro fica próximo à UFJF e é dirigido por um pai de santo jovem, numa região conhecida como "Cidade Alta". Em ambos os locais, a presença física do pesquisador e o contato com o povo de santo dessas casas proporcionaram as entrevistas necessárias para o complemento do trabalho. No entanto, o pedido de extensão do prazo de pesquisa e a chegada da pandemia de COVID-19 estacionou os respectivos relatos e surgiram dificuldades para realizar entrevistas dado a não realização de sessões e festas promovidas pelas casas e pelos terreiros.

Adentrar no campo, conhecer as formas rituais na prática é o recomendável quando se trata de comunidades tradicionais de terreiro. Mas a pandemia impediu, de certa forma, de contribuir com mais visitas em diversos terreiros e locais que 
diferenciam do padrão Umbanda e Candomblé da cidade de Juiz de Fora. Não foi possível conhecer a Quimbanda e os rituais após a meia noite em terreiros que trabalham com as linhas direita e esquerda de Umbanda.

Sobre os locais visitados, serão abordados aqui os casos da Religião de Umbanda e dos locais centrais da cidade. A localização de terreiros e tendas umbandistas em regiões de alta densidade demográfica permite-nos refletir sobre os aspectos que possibilitaram a utilização destes espaços sem comprometer as estruturas da sociedade repressiva e das proibições como a "Lei do Silêncio". Por exemplo, os terreiros centrais, não utilizavam tambores em seus rituais, ou canto ou som de um pequeno aparelho de som.

A primeira entrevista foi realizada em um horário noturno e antes da reunião na casa. A casa é simples, com poucas imagens, e no dia poucos membros frequentaram a sessão. A entrevista foi conduzida de forma rápida, aprazível e sem complicações ou receios sobre as perguntas, o que demonstra que o questionário elaborado é fácil e rápido de responder.

Nesta casa, homens e mulheres sentavam-se em lados opostos. A entrevista não foi realizada direto com um responsável pela casa, mas com uma médium, branca, com mais de cinquenta anos, denominada de Entrevistada A. Ela respondeu de forma bem sucinta as questões principais para a pesquisa. Entretanto, não respondeu sobre o tempo de existência do terreiro e apresentava cinco anos de filiação ao terreiro. Contudo, foi cirúrgica ao responder sobre o que entendia a respeito da intolerância religiosa, isto é, uma falta de respeito com a sua religião.

Em outra casa de Umbanda, que foi visitada por diversas vezes, não houve a necessidade de utilização do questionário. As conversas com o presidente e outros membros da casa, e um que utiliza da benzeção e atende no domicílio, foram úteis 
para a conclusão de que não ocorreram ataques intolerantes nesta casa que atua na região central. Nos principais dias para trabalhos de desenvolvimento, desobsessão, caridade e fé, as entidades que atuam na casa promovem a harmonização e o controle das atividades de caridade.

A casa apresenta capacidade para um total de cem pessoas sentadas e as auxiliares e os auxiliares, onde ficam lotadas as cadeiras. Não há discussões sobre o tema intolerância religiosa, visto que frequentei por meses e o assunto não foi discutido uma vez sequer. Conhecimento sobre associações e federações não há comentários, também. Sobre aqueles que realizam intolerância religiosa, não há espaço para discussão. As palestras lembram a de uma casa espírita e os temas são parecidos com os trabalhados nas palestras kardecistas, utiliza-se os livros de Kardec e outros autores espíritas e umbandistas, no centro há uma pequena biblioteca e venda de livros. A festa de Cosme e Damião nessa casa fica lotada antes do início da palestra. O presidente é branco e maioria dos auxiliares, também. O médium que faz a benzeção é pardo e poucos trabalhadores e trabalhadoras da casa são negros e pardos.

As visitas realizadas ao terreiro do Dom Bosco foram antes da pandemia e pela forma como foi desenvolvido os trabalhos da casa não permitiram a retirada de documentos ou outros recursos para a entrevista. Mas, situações fortuitas como o falecimento de um parente de um médium da casa, oportunizaram o diálogo sobre a casa e as especificidades dela. Antes de quaisquer trabalhos que venham a ser feitos, a pessoa que visita ou até mesmo a que frequenta deve utilizar de rituais de purificação como banhos de limpeza para não carregar o ambiente. O trabalho é feito com o gongá aberto e o chão é de terra batida. Em uma conversa com a dirigente da casa, uma mulher negra, Entrevistada B, ela revelou que a terra batida 
no terreiro não é uma terra qualquer é uma terra retirada de cupinzeiros e depois, cuidadosamente, assentada nesse terreiro que guarda características de práticas e costumes dos que criaram a casa. O único caso de ataque que essa senhora relatou foi um roubo praticado no terreiro e que, prontamente, foi recuperado os itens pelos frequentadores. A casa recebe muitos universitários, por estar próxima da UFJF. O bairro tem em sua maioria uma população negra e a maioria dos alunos do ensino médio da escola do Estado onde leciono são moradores desse bairro.

O último local da Umbanda é de um ramo que é conhecido como Omolokô. O responsável pela casa, que de início, parecia abandonada, foi revelando um entusiasta pela transformação do ser em sua plenitude, talvez seja esse o propósito da Umbanda Omolokô, transformar a pessoa e trabalhar nesse sentido restaurador das potências de cada ser humano, sem desconsiderar o próximo e muito menos a natureza e a vida que nos dá as condições para a sobrevivência. Essa liderança, o Entrevistado $C$, tem um trabalho no bairro Jardim Casablanca e imediações de recuperação de jovens com problemas sociais graves, como o consumo de crack e outras drogas ilícitas. O trabalho social e a facilidade dessa liderança de lidar com diversas questões da vida, leva a casa, mesmo que pareça abandonada a ter nenhum relato de ataques contra ela. Nunca houve esse problema e o ritual parece com uma sessão espírita, a liderança recebe as entidades e desenvolve todo um aspecto de conselhos e orientações aos presentes na mesa. Isso mesmo, os ajudantes, a liderança e os frequentadores todos sentados em volta de uma grande mesa. Poucos frequentam, no máximo dez pessoas, mas o trabalho desenvolvido e essencial para o crescimento interior e para a proteção dos frequentadores. Enfim, a liderança atua como se fosse um pai, que orienta, disciplina e organiza a casa conforme as suas determinações. 
O Entrevistado $\mathrm{C}$ possui o superior completo, é branco e tem cinquenta e cinco anos de serviço na Umbanda. Ele presenciou um ato de intolerância, onde uma pessoa na Loja Maçônica de Brasília que a outra era ligada a Umbanda e não poderia frequentar a Loja, pois "a Umbanda é do demônio". Ele buscou resolver o problema com diálogo e não foi em busca de autoridades para dissuadir o fanático religioso. Ele aborda sobre o assunto, intolerância religiosa em sua casa e conhece o trabalho do ex-vereador e atuante em uma federação em defesa das religiões afrobrasileiras da cidade a FREDRETOC e sobre a questão racial.

Abordamos sobre as casas de Umbanda e agora abordaremos os terreiros cruzados Candomblé e Umbanda.

O terreiro próximo do bairro Igrejinha na Zona Norte da cidade, tem um amplo espaço e um trabalho reconhecido na cidade e pela UFJF, onde diversos estudantes frequentam para ter uma referência de um Candomblé Ketu, como afirma o Pai de Santo, liderança do terreiro, denominado Entrevistado D. A organização do terreiro é ímpar, belíssimas festas e uma movimentação constante de diversos ogãs, ekedis, iaôs, lalorixás, Babalorixás e visitantes do terreiro. As festas movimentam a região e dinamizam o comércio local.

Com relação aos tópicos abordados no questionário, em entrevista realizada por telefone, o responsável pela casa afirmou possuir ensino superior completo e vinte anos de filiação à casa, que possui setenta anos de existência. De acordo com este entrevistado, a intolerância é entendida como um desrespeito, opinião corroborada pelo entrevistado $\mathrm{E}$

Intolerância religiosa, para mim, significa a ofensa e a ideologia pela não aceitação das práticas e costumes religiosos, gerando assim o ódio. Nesse caso, como exemplo, os neopentecostais e os seus discursos de ódio, direcionada ao culto e rituais do candomblé (ENTREVISTADO E, 2020). 
O Entrevistado $G$ analisa a intolerância como um sentimento gerado devido às diferenças de crenças

\begin{abstract}
Intolerância religiosa é um sentimento, uma ação de determinados grupos, uma vontade deliberada de desrespeitar a fé e os espaços religiosos dos grupos ligados às religiões de matriz africana, gerando conflitos. Está ligado às religiões "normativas" (Catolicismo e Protestantismo) e seus poderes ao longo da história. Para esse grupo, tudo que difere de suas crenças, é alvo de intolerância (ENTREVISTADO G, 2020).
\end{abstract}

A intolerância foi classificada pelo Entrevistado $\mathrm{H}$ como "...a falta de vontade de pessoas e instituições em respeitar a religião do outro e em nome dessa falta de respeito, perseguem, demonizam, discriminam, agridem" (ENTREVISTADO H, 2020). Para o Entrevistado F, intolerância e racismo religioso são problemas distintos, mas às vezes confundidos

Num primeiro momento, sempre fui contra essa forma de racismo religioso ser tratada como intolerância. Considero subjetiva. Ter intolerância à lactose, ter intolerância ao mau-caratismo. Soa como sentimento e nesse aspecto estaria mais na questão afeta a cada pessoa que um crime ser intolerante. Entretanto, a intolerância hoje funciona como desrespeito. Já sempre defendi que o crime seria o desrespeito e não a intolerância, apesar que ambos só se materializam na ação. A intolerância religiosa, a exemplo do desrespeito religioso, só vai ser considerado como crime conforme o tipo de ato: vilipendiar, usar de preconceito, atacar a dignidade humana no direito de ter sua opção religiosa. Por exemplo, a discriminação religiosa no $\S 3^{\circ}$, do art. 140, do Código Penal, vai gerar uma reclusão de um a três anos e multa. Já o art. 208 do Código Penal assegura detenção de um mês a um ano ou multa para casos graves como o vilipêndio de ato ou objeto religioso ou desrespeito público à crença religiosa (ENTREVISTADO F, 2020).

Dessa forma, é possível encontrar um denominador comum na opinião dos entrevistados: todos concordam com a ideia de que a intolerância é fruto de ideologias, desrespeitos e preconceito.

Tais opiniões comungam, portanto, com as obras de autores nesta pesquisa utilizados. O branqueamento, como foi visto, se tornou o modelo universal para a humanidade (BENTO, 2003), o que reforçou a supremacia econômica, política, social e, principalmente, religiosa da elite branca brasileira. Do outro lado, destarte, 
ficaram aqueles cujas religiões e fé passaram a ser estigmatizadas, atacadas, ofendidas e invadidas constantemente, seja por pessoas ou por instituições. As agressões dos intolerantes, cujo foco não é a verdade (GOMES, 2009), teriam por base uma suposta expulsão e luta contra o mal e o próprio demônio (SILVA, 2007/2015), resultantes, assim, de uma concessão do poder constituído pelos grupos dominantes, no caso do Brasil, os brancos (ESTRAMIANA; SEVERIANO, 2003, p. 17).

De acordo com o relato de uma entrevistada, a intolerância contra os médiuns geralmente é ocultada pela agressividade dos fiéis das religiões ao tratar com o povo de santo. A superioridade em suas convicções religiosas, a arrogância ao lidar com pessoas que não têm a mesma fé cristã, provocam-nos ao ponto de partir para agressões ao que para o fanático religioso é alguém que está a serviço do demônio ou algo relacionado a isso. A Teologia da Batalha Espiritual transforma o cotidiano dos fanáticos das representações evangélicas em seres humanos que não reconhecem a humanidade e a religiosidade que difere da sua.

Ao serem indagados sobre atos de intolerância contra o terreiro ou contra alguma pessoa conhecida do local de reuniões que frequentam, a maior parte dos entrevistados foi capaz de citar exemplos de fatos presenciados ou ocorridos com pessoas conhecidas

Sim. Como a população da cidade é de maioria católica, um filho de nossa casa, que reside na cidade, foi abordado pelo pároco. O mesmo, segundo o filho, diz que aqui, "fazemos macumba para os outros" e que ele deveria sair e ir para a igreja porque lá, está a casa de Deus (ENTREVISTADO E, 2020).

A recordação mais viva em minha mente, foi quando entrei para a minha primeira casa que foi no candomblé, me lembro que sempre éramos assediados por testemunhas de Jeová, que viam quando estávamos realizando as obrigações da casa e iam interferir, querendo fazer estudos e convidar para conhecer a religião. Nunca fui de responder, sempre ouvia e só tolerava, mas uma vez precisei me posicionar firme, quando eles começaram a dizer que "Jesus me amava independente de eu estar 
praticando algo errado, respondi "Ogum também te ama" apesar do seu preconceito, seu racismo com a fé do seu próximo, ele te perdoa, eu não sabia que quando Jesus nos mandou amar o próximo, era pra amar só aqueles que pensam e agem iguais a nós (ENTREVISTADO I, 2020).

O Entrevistado F relatou a ocorrência de diversos casos de intolerância, não

na casa em que frequenta, e justificando o conhecimento devido à posição que ocupa socialmente: "Como Diretor Jurídico do CENARAB - Centro Nacional de Africanidade e Resistência Afro-Brasileira, já fui chamado a intervir em 'n' casos de intolerância religiosa" (ENTREVISTADO F, 2020). O primeiro caso relatado por ele ocorreu no bairro Santo André, no estado de São Paulo

\begin{abstract}
Uma Comunidade-Terreiro no Bairro Santo André, de Mameto Fátima de Yemanjá teve denúncia de cárcere privado de uma garota que estava sendo iniciada. Chegaram várias viaturas com pessoal armado de fuzis e uma tenente tentou entrar no quarto onde a noviça estava recolhida. Denúncia de uma parente da família, de religião neopentecostal. A criança tinha a mãe e a avó de religião de matriz africana e estavam acompanhando a feitura da criança. A tenente foi impedida e só conseguiu ver a criança quando se submeteu a ficar descalça para pisar no local sagrado. Isto foi em torno das treze horas e até às vinte e três horas estávamos em delegacia lavrando o Boletim de Ocorrência quanto ao fragrante desrespeito às normas constitucionais e infraconstitucionais (ENTREVISTADO F, 2020).
\end{abstract}

\title{
Outros casos relatados por ele também ocorreram no mesmo estado
}

$\mathrm{Na}$ Comunidade-Terreiro da falecida Mameto Kitulá, no Bairro Jardim América, vez por outra aparecia evangélicos disfarçados em assistentes para se consultar com as entidades e em dado momento começavam a fazer pregação contra a religiosidade dos presentes. Nossa orientação sempre foi no sentido de fazer a retirada com o menor uso de força possível (ENTREVISTADO F, 2020).

Numa das Festa dos Pretos Velhos no Bairro da Graça já intervi também para evitar linchamento de evangélicos que estavam panfletando contra as religiões de matriz africana, desrespeitando o culto religioso no local (ENTREVISTADO F, 2020).

Este entrevistado deu ênfase especial ao seu último relato, devido à grande repercussão adquirida pelo caso

Temos um caso emblemático em São Joaquim das Bicas, onde um cabo aposentado da polícia militar e evangélico já invadiu uma comunidadeterreiro, com truculência e armado, acompanhado de outros policiais. As providências tiveram que ser tomadas em Belo Horizonte porque o cabo tem apoio da polícia civil da cidade. Então os casos acima são apenas exemplificativos. Tivemos caso de muita repercussão em Santa Luzia 
quando o Ministério Público, provocado por intolerância de vizinhos à comunidade de terreiro, estabeleceu como seriam os dias e as formas de culto de uma Comunidade-Terreiro, porque o vizinho é da Polícia Militar e evangélico. Infelizmente, na época, acionamos até o Ministério Público Estadual e não conseguimos desfazer o Termo Circunstanciado de Ocorrência que os zeladores foram obrigados a assinar. Houve outro caso idêntico no mesmo município e Bairro (Bonanza) onde um vizinho militar e evangélico tentou desrespeitar o culto de outra comunidade-terreiro, essa da Mameto Muiandê que tem uma força política muito grande em Belo Horizonte, onde sua comunidade-terreiro foi tombada como quilombo, e por isso as ameaças dele não foram frutíferas (ENTREVISTADO F, 2020).

Nenhum ato de intolerância foi dito pelos ogãs ou mesmo pelo Babalorixá, apesar da proximidade de denominações evangélicas, nunca ocorreram ataques ou problemas com os membros ou com as visitas. O terreiro até poderia ser atacado por estar numa localidade onde não ocorre um policiamento constante e é muito distante do centro da cidade e com poucas linhas de ônibus urbano para atender. Contudo, o trabalho desenvolvido pelo terreiro na localidade é de vital importância para mesma, tanto que as festas no terreiro, movimentam a região e dão oportunidades de integração e reconhecimento para os membros que moram nas proximidades. Um dos pais pequenos tem uma casa de umbanda em outro bairro que foi frequentado antes mesmo de dar início as atividades de pesquisa. Foram realizadas consultas e só não foi dada continuidade aos trabalhos pela distância da casa.

Apenas uma entrevistada afirmou desconhecer casos de intolerância religiosa em no terreiro que frequenta, por meio da fala "Desconheço que meu Terreiro ou algum membro dele tenha sofrido ataques de intolerância religiosa" (ENTREVISTADA G, 2020).

Neste ano, foi realizada a visita a outro terreiro cruzado, só que este era bem próximo de casa e frequentei uma única vez e fui bem recebido pelo responsável pelo terreiro. Realizei a entrevista com o Babalorixá (Entrevistado $\mathrm{H}$ ), jovem com apenas trinta e cinco anos e vinte anos de trabalhos realizados, tempo que coincide 
com o tempo de existência do terreiro. O rapaz nunca viu atos de intolerância, o terreiro não trabalha com o tema. Contudo, quando indagado sobre os atores que praticam atos intolerantes, ele aponta os evangélicos como responsáveis por determinadas atitudes. O rapaz não conhece sobre associações de Juiz de Fora e há uma espécie de proteção por parte de uma federação do Rio de Janeiro, uma federação umbandista, fato relatado por outro integrante do terreiro.

A discussão sobre e ocorrência de intolerância religiosa foi relatada por todos os entrevistados, exceto pela Entrevistada $\mathrm{M}$, que não respondeu à questão. As discussões sobre o tema ocorrem com frequência, mesmo em casos em que não ocorrem abusos, conforme relatado pela Entrevistada G "Sim. Procuramos sempre debater sobre todos os assuntos que envolvem nossa comunidade e este tema é um deles" (ENTREVISTADA G, 2020). A discussão também ocorre de maneira informal, conforme mencionado pela Entrevistada I "Não, formalmente não. Mas, informalmente nos diálogos entre os médiuns da casa o assunto sempre surge" (ENTREVISTADA I, 2020).

O Entrevistado $E$ faz questão de frisar a busca de solução por meio de autoridades e não por violência física: "Sim. Principalmente quando um filho está fazendo a obrigação dele. Digo a ele que se alguém falar mal de sua religião, que procure as autoridades, mas que não brigue fisicamente" (ENTREVISTADO E, 2020).

O entrevistado $F$ afirma que são realizadas reuniões educativas quanto ao tema pela instituição em que atua

Sim. Temos, através de reuniões do CENARAB, mostrado aos zeladores e zeladoras seus direitos, como se prevenir no caso de recolher menores de idade, como agir quando for desrespeitado seu direito constitucional de culto, entre outras coisas do gênero (ENTREVISTADO F, 2020). 


\title{
Os entrevistados apresentam opiniões a respeito das causas da intolerância
}

\author{
religiosa. Como causas mencionadas estão o desconhecimento das religiões, \\ preconceito e diversas formas de racismo
}

Em minha opinião, as principais causas que levam a prática da intolerância contra as religiões afro, está ligada pela falta de conhecimento, o racismo estrutural e a questão religiosa que muitos indivíduos da classe média alta possuem e fazem parte, respectivamente, levando outros indivíduos de outras classes, como a classe média baixa, a serem usados como "massa de manobra" para os seus atos, levando assim, gerar intolerância junto as religiões afro (ENTREVISTADO E, 2020).

A principal causa é o racismo religioso introjetado nas pessoas, principalmente nos frequentadores das igrejas neopentecostais. Nessas igrejas criam o confronto entre Deus e o Diabo, sendo eles os bons e os religiosos de matriz africanos os maus. São contra os rituais de purificação, de iniciação, da sacralização de animais. $O$ avanço dos evangélicos junto aos militares e marginais fazem com que o vilipêndio de locais sagrados, a destruição de símbolos, o desrespeito à forma de culto, fiquem impunes. Hoje os religiosos de matriz africana contam com o apoio das forças políticas progressistas, a exemplo de partidos políticos como PT, PSOL, PCB; com o apoio das organizações sociais progressistas como Movimento Social dos Negros, Movimentos culturais a exemplo das Escolas de Samba, entre outros. Para se ter uma ideia, eu fui apresentado em sessão pública como iniciado em treze de janeiro de mil novecentos e setenta e nove. Iniciei minha militância junto aos religiosos de matriz africana em torno de mil novecentos e oitenta e quatro. Em mil novecentos e oitenta e seis, comecei minha militância no movimento negro. Na época, não havia um militante do Movimento Negro aqui em Belo Horizonte que fosse de religião de matriz africana. Hoje, deve haver cerca de $80 \%$ do Movimento Negro, incluindo pessoal do Samba, dos Quilombos, da Capoeira, da Dança Afro, do Teatro, da Música, atuando dentro das religiões de matriz africana: Candomblé, Umbanda, Congados (ENTREVISTADO F, 2020).

Para mim e acredito que para a maioria dos adeptos das religiões de matriz africana, as causas desse conflito vão desde o desrespeito, a incapacidade de aceitação da nossa religião, até o racismo e cerceamento do nosso direito (direito esse constitucional) de cultuarmos livremente nossas crenças. Os protestantes (evangélicos) são os mais intolerantes (ENTREVISTADA G, 2020).

Eu acredito que, por ser uma religião de matriz africana, praticada originalmente por pessoas negras... então a causa está diretamente associada ao racismo. Por isso que alguns grupos nem falam mais em intolerância religiosa, falam em racismo religioso, porque a discriminação contra essas práticas religiosas está diretamente relacionada ao racismo. $\mathrm{E}$ por conta de ela possuir valores, tradições e práticas muito diferenciadas do Cristianismo, como por exemplo não ser maniqueísta, é... tratar a sexualidade como uma coisa natural em relação ao ser humano, em relação a homens e mulheres... então é uma religião que tem entidades que trabalham especificamente com essa questão da sexualidade, assim como trabalha também diferenciadamente a questão do... da sedução, como por exemplo o orixá Oxum. Isso ser uma coisa que desde sempre o cristianismo considera como práticas pecaminosas, como tabu, principalmente 
relacionada às mulheres... é possível que essa também seja uma causa da intolerância (ENTREVISTADA H, 2020).

Acredito que a causa da intolerância contra as religiões de matrizes africanas é o racismo, os séculos de escravidão, deixaram heranças inúmeras, que precisam ser discutidas, escancaradas para que assim, sigamos para um dia quem sabe o extermínio. A sociedade tem a tendência a rejeitar e demonizar tudo o que venha do negro e com a religiosidade não é diferente (ENTREVISTADA I, 2020).

Quando questionada sobre quais as causas da intolerância contra as religiões de comunidades tradicionais de terreiro e quais os setores sociais mais intolerantes contra as religiões afro-brasileiras a Entrevistada $G$ afirma serem os evangélicos

Para mim e acredito que para a maioria dos adeptos das religiões de matriz africana, as causas desse conflito vão desde o desrespeito, a incapacidade de aceitação da nossa religião, até o racismo e cerceamento do nosso direito (direito esse constitucional) de cultuarmos livremente nossas crenças. Os protestantes (evangélicos) são os mais intolerantes (ENTREVISTADA G, 2020).

Dessa forma, o racismo foi constantemente citado pelos entrevistados como uma das causas da intolerância religiosa. Isso porque é o racismo epistêmico, pautado na aparência negroide, que respalda todas as deslegitimações, violações, ataques e até mesmo a criminalização das práticas religiosas mencionadas neste estudo e, por que razão, é ainda o racismo religioso a prova e afirmação da africanidade que tais práticas carregam (FERNANDES, 2017).

O entrevistado K, é homem, residente no interior de São Paulo, e tem seu templo na mesma cidade. Como liderança relatou casos interessantes de como enfrenta dificuldades de alugar um imóvel com a finalidade de instalar um centro ou terreiro, devido à intolerância religiosa. Caso afirme isso de imediato, não consegue um contrato de locação

A incapacidade do ser humano, religioso ou não, de compreender que há outras verdades além da sua e respeitá-la, não ultrapassando os limites do bom senso, nem das leis constitucionais, que separam a opinião contrária da oposição violenta, seja verbal, física, ou de outras forças, como política e social. Sim, mas nada que não pudesse ser contornado. É mais fácil um vizinho aceitar um bar ou aglomeração de baile funk do que os sons dos 
atabaques do terreiro. Chamo a atenção também para a dificuldade que os terreiros têm de alugar imóveis quando o objetivo é declarado logo de início. Sim claro. Não só sobre intolerância religiosa, mas também racismo, homofobia, e outras fobias tão presentes na nossa sociedade (ENTREVISTADO K, 2020).

A opinião desse entrevistado sobre as causas da intolerância é interessante e instigante para a nossa pesquisa e para refletir sobre as opiniões de lideranças de comunidades tradicionais de terreiro sobre esse contexto de Batalha Espiritual e suas consequências no Campo Religioso Brasileiro

\begin{abstract}
As causas são endêmicas na nossa sociedade e remontam os tempos atuais. Não aceitar outras religiões vem da história das religiões. E algumas que já estiveram no poder, ensinaram aos seus seguidores essa intolerância em tempos passados e essa herança alcança esses nossos tempos. Há de se observar que muitos religiosos dessas bases tentaram mudar as coisas, mas essas tentativas têm sido infrutíferas. Principalmente as religiões de base cristã tem essa premissa. E parte do princípio que ser cristão, para alguns, é um qualificador de poder. Pense na afirmação: - Sim, sou melhor do que vocês todos pois sou cristão, um homem de Deus e minhas opiniões são as melhores. Estou certo e todos vocês errados! Parte desses religiosos se dedicou à busca do poder, não só religioso, mas político e social (financeiro mesmo). E usam isso para seu próprio benefício. Tem no proselitismo desqualificador do diferente, uma arma das suas armas de conversão. E se servem das brechas de dentro das próprias religiões de matriz afro, que não se preocuparam em se organizar, teológica e socialmente, e se dedicam apenas aos seus interesses particulares, pessoais e de terreiro, e que permitem esses ataques por não explicar de forma coerente e racional a sua teologia, teogonia e doutrina. Temos nas figuras das nossas federações e organizações esse apoio. E na lei vigente, na solicitação às polícias e à justiça. Associações o entrevistado tem conhecimento através dos canais de comunicação e pelas redes sociais (ENTREVISTADO K, 2020).
\end{abstract}

As atitudes tomadas diante de um ato de intolerância foram relatadas. A entrevistada de um dos terreiros centrais informa que não ocorreu ato na casa. O Entrevistado E afirma que o agredido deve "procurar os direitos, junto as autoridades para que atos de intolerância não ocorram mais" (ENTREVISTADO E, 2020). Os Entrevistado F e G também concordam com a resolução por meio da busca judicial por direitos, demonstrando conhecimento sobre associações e federações na cidade e no país, destacando a importância de reagir diante dos ataques intolerantes 
de esclarecer os religiosos sobre seus direitos e as formas de valerem esses direitos. Temos casos de apenas orientar e notificar os autores da intolerância, temos casos de orientar fazer o Boletim de Ocorrência e acompanhar, e casos mais graves temos a parceria com a Defensoria Pública, o Ministério Público Estadual e Ministério Público Federal, temos o apoio das Comissões da OABMG de Direitos Humanos, Igualdade Racial, Direito e Liberdade Religiosa, CPIR da Prefeitura Municipal, entre outros (ENTREVISTADO F, 2020).

No meu Terreiro não aconteceu, mas acredito que a atitude mais correta é procurar a Justiça (advogado) para garantir nosso direito. Como Jornalista acredito que a imprensa também tem um papel importante ao publicizar atos de intolerância. Acredito que a passividade não é o melhor caminho (ENTREVISTADA G, 2020).

O registro formal da denúncia por meio de boletim de ocorrência foi relatado

pela entrevistada I

Acredito que deva ser feito uma denúncia e boletim de ocorrência. Em Juiz de Fora temos também o Conselho de Igualdade Racial, para dar suporte. Afinal existe lei que prevê punições para crimes de discriminação e ofensas e vivemos em um país laico (ENTREVISTADA I, 2020).

A Entrevistada $\mathrm{H}$ afirma que não presenciou a tomada de atitudes nos terreiros que já frequentou

Com relação às atitudes tomadas, nos dois terreiros de que fiz parte, nunca foi tomada e nenhuma atitude com relação aos atos de intolerância. No primeiro terreiro, que era um terreiro de candomblé... é... já houve vários ataques de pessoas evangélicas mesmo, de vizinhança do terreiro e a lalorixá, no caso, nunca reagiu a esses casos de intolerância. E no segundo terreiro, como esses casos não eram nem discutido também nunca foi feito nenhuma ação. Eu já conheci pessoas que me pediram, que sofreram intolerância e que me pediram orientação e eu encaminhei para algum... para advogados que eu conhecia, e também para a Comissão de Direitos Humanos da Câmara Municipal para formalizar uma denúncia e também por conta disso foi realizado uma audiência pública para discutir essa questão (ENTREVISTADA H).

O conhecimento sobre associações e federações de combate à intolerância religiosa não foi relatado pela entrevistada da primeira casa visitada. Além disso, ela desconhece ações de combate à intolerância religiosa na cidade, no Estado e no Brasil, ela, também, não tinha conhecimento e não sabia responder sobre esses órgãos. Essa fala corrobora com a da Entrevistada E, que afirma que existem poucas associações e federações que lutem contra a intolerância religiosa: "Acredito 
que muito pouco" (ENTREVISTADA I, 2020). Os demais entrevistados afirmam conhecer algumas associações localizadas em Juiz de Fora

Sim, a associação espírita de Juiz de Fora, mas infelizmente não conheço a sua estrutura e o modo de trabalho junto as religiões afro (ENTEVISTADO E, 2020).

Existe uma federação em Juiz de Fora (FENACAB - Federação Nacional de Culto Afro-brasileiro). Contudo, não sei sobre as ações desta Federação. Alguns setores e comunidades na cidade realizam encontros, palestras, eventos, voltados a essa temática. Mas, desconheço ações efetivas de combate à intolerância religiosa em Juiz de Fora (ENTREVISTADA G, 2020).

Em relação às associações que realizam trabalho de combate à intolerância religiosa que eu conheço são Comissão de direitos humanos da $O A B$ e eu faço parte também de um grupo de igualdade religiosa, que também trabalha... fazia alguns eventos para discutir essa questão e também tinha uma parceria com advogados da OAB (ENTREVISTADA H, 2020).

O Entrevistado $\mathrm{F}$ ainda informa sobre o conhecimento de associações no estado do Rio de Janeiro ou de atuação Nacional

Temos, além das listadas acima, parceria com a CONEN - Coordenação da Entidades Negra que atua em nível nacional; CEAP - Centro de Articulação de Populações Marginalizadas, do Babalaô Ivanir, do Rio de Janeiro; O IARA - Instituto de Advocacia Racial e Ambiental, do Dr. Humberto Adami; IDAFRO - Instituto de Defesa dos Direitos das Religiões Afro-Brasileiras, do Dr Hédio Silva Júnior; etc. (ENTREVISTADO F, 2020).

Antes da entrada das religiões afro-brasileiras na era digital relatarei sobre a iniciação de uma criança de apenas cinco meses, a mãe é iaô e a criança, cedo, percorrerá os caminhos dos mistérios do Candomblé. Muitos jovens no terreiro e com uma definição sobre a sexualidade muitos homossexuais masculinos e jovens, e, até uma trans, o que demonstra uma abertura do terreiro para as questões de gênero e uma oportunidade completa de pesquisas sobre gênero e religiões de comunidades tradicionais de terreiro.

O Entrevistado $\mathrm{H}$ deu informações sobre o seu canal no YouTube, Instagram e Twitter, esse relato é importante, pois em um vídeo que assisti do seu canal ele relata uma situação de intolerância sobre as suas vestimentas de santo, no que a 
evangélica disse que estava amarrado e ele retrucou que estava amarrado em nome do orixá Exu. Sempre bem-humorado ele relata sobre situações cotidianas no terreiro e aspectos de convivência e relacionamento dentro das religiões afrobrasileiras.

Outra situação que merece destaque é que o mesmo rapaz quer utilizar estes canais para divulgar sobre a religiosidade de comunidades tradicionais de terreiro e o que é interessante, políticos de esquerda ajudam os terreiros e conversam sobre uma maior contribuição dos políticos para evitar o esquecimento e até o abandono dessas comunidades.

O entrevistado J, por meio eletrônico, correspondeu e demonstrou interesse no questionário e na valorização do trabalho de pesquisa. Sendo uma liderança e respondendo por seu terreiro, poderia ter correspondido com mais informações. Talvez as perguntas não tenham estimulado o entrevistado a responder mais, o que uma entrevista, frente a frente com o entrevistador poderia deixar mais seguro para falar mais sobre a temática. Ele entendeu sobre o tema e relatou algo que acontece na sua volta com os relatos de terceiros. Mas, a providência sobre esses boatos pode ser verificada pessoalmente com a liderança religiosa contestadora. No caso uma pergunta direta a autoridade intolerante seria uma forma de comprovar os boatos, pois se o tema é discutido deverá ser comprovado a atitude hostil ao religioso afro-brasileiro, principalmente, devido ao pouco tempo de liderança e de terreiro. Os intolerantes querem o fechamento de terreiro, para eles isso é um prêmio

Entendo que é toda a forma discriminatória, praticada por um indivíduo à uma religiosidade, devido a sua falta de habilidade em reconhecer e respeitar as diferenças de crenças. Como a cidade é em sua maioria católica e pentecostais, ouve, segundo relato, o padre dando conselhos aos fiéis sobre como é errado esse tipo de religiosidade, principalmente no que 
tange o sacrifício. Mas como foi relato de terceiros, não tomamos providência. Junto aos integrantes e filhos da casa. Sempre dizemos e orientamos que qualquer forma discriminatória não condiz com a nossa religião e de nenhuma outra. Sempre se orgulhar e levantar a cabeça pois, somos todos iguais. Em minha opinião, vejo que a principal causa da discriminação, está relacionado ao racismo e a desinformação cultural religiosa. Por ser uma religião não do livro e que chegou ao Brasil com a diáspora africana nos navios negreiros, a intolerância não é só, contra a nossa religiosidade, mas, contra toda a nossa expressão cultural. Levar ao conhecimento das autoridades. Crimes desse tipo não pode ficar calado porque, caso não denunciarmos os, caso puder a ocorrer novamente, nos tornando assim, sujeitos passivos. Na cidade de Juiz de Fora, existe uma associação, mas até então, essa mesma, chegou aos meus conhecimentos informações muito superficiais, tais que relataram que não existem mais. No Brasil, existe todo ano as caminhadas contra a intolerância religiosa, mas acontece nas grandes capitais como em São Paulo e Rio de Janeiro e Salvador. No Sul também acontece essas passeatas, mas as informações chegam até nos de forma vagas (ENTREVISTADO J, 2020).

Na cidade de Juiz de Fora, o cenário de intolerância religiosa existe. Porém, não é complicado como no Rio de Janeiro e em outros locais no Brasil. Mesmo assim, o tema da intolerância religiosa é abordado na cidade e, em breve, após a pandemia, atos deverão selar um respeito às comunidades tradicionais de terreiro. $A$ iniciativa do Legislativo Municipal da cidade reflete a necessidade de tratar da temática ${ }^{35}$, nos comentários o racismo religioso escancarado pelos "cidadãos de bem" e seu vitimismo da "cristofobia". Respeito é o que todos querem, daí não deveria ser usado a questão da intolerância. As lideranças e o povo de santo da cidade deveriam mudar o nome da proposta para o dia de combate ao racismo religioso na cidade.

A entrevista em questão trouxe novidades sobre outros Estados, uma vantagem dessa pandemia, quando ocorre uma boa vontade por parte do entrevistado em dispor de seu tempo para responder algo que é de seu interesse, possui um longo período de filiação no terreiro

\footnotetext{
${ }^{35}$ Disponível em: <https://tribunademinas.com.br/noticias/politica/08-09-2020/vereador-quer-criacao-de-dia-decombate-a-intolerancia-religiosa.html>
} 
Entendo que intolerância religiosa engloba uma serie de atitudes que vão desde ignorar uma pessoa ou grupo em razão e crenças religiosas, atravessar a rua para não passar pelo outro, virar a cara, cuspir, xingar até atos como negar empregos, atirar pedras em pessoas e terreiros, demonizar a religião alheia, desqualificá-la, impedir acessos de seus membros a lugares e postos de trabalho, práticas de silenciamento e apagamento de memória diversas, incluindo as referentes à sua existência e lugar histórico, até as violências físicas mais extremas como destruição de templos e assassinato de membros. Tenho acompanhado alguns casos desde a formação da A Comissão de Combate à Intolerância Religiosa (CCIR) e, por vezes, recebo relatos de diferentes tipos de atos intolerantes em diversos lugares no Brasil. Este me é um tema caro desde 2007 quando comecei atentar para ele. Em primeiro lugar, vejo um projeto de poder e hegemonia que obviamente inclui o lado econômico do mercado religioso, sendo realizado principalmente pelas igrejas neopentecostais que visa às religiões afro-ameríndio-brasileiras por sua maior fragilidade, mas que aos poucos vão também tomando atitudes contra os demais cristãos. Penso que certos grupos neopentecostais (IURD), alguns grupos mais fanatizados da Assembleia de Deus e Testemunhas de Jeová, e um pequeno, mas perigoso grupo de carismáticos e conservadores católicos. No entanto, não se deve esquecer que muito da força que poderia ser obtida pela união das religiões afro-ameríndio-brasileiras se esvai em suas próprias querelas e intra-intolerâncias. No que respeita ao indivíduo intolerante, o medo do desconhecido ou do que o senso comum indica a respeito das religiões de matriz afro, e os religiosos de outras vertentes pregam, faz com que muitas pessoas se tornem fanáticas, incapazes de aprender sobre, sendo por isso um ignorante, e de pensar de forma crítica. Além disso, muitas vezes, aquele fanático que quer converter o outro, livrá-lo do Mal e salvá-lo, realmente acredita nisso e está dando o seu melhor.

Penso que as pessoas que sofrem atos de intolerância religiosa, reagem de formas distintas conforme seu perfil, seus conhecimentos e recursos, seu nível de engajamento e crença de que suas ações terão consequências para quem praticou o ato de intolerância seja ele vindo de pessoas, ou instituições, ou, ainda, do próprio poder público em alguns casos. No geral, quando o caso é grave ou repetitivo, vai-se às redes sociais, aos jornais, à CCIR, à polícia, à justiça, à políticos. Nem sempre obtendo resultados práticos (ENTREVISTADO J, 2020).

O entrevistado L é homem e atua no interior do Rio de Janeiro como liderança

de terreiro. A sua visão sobre a intolerância é fundamental dado a sua visão de liderança, não sofreu ataque intolerante. No entanto, a lalorixá que tem ligação sofreu pela internet. Tal fato demanda uma maior observação das autoridades que deixam as redes sociais como uma terra sem lei e onde todos os tipos de crimes seguem sem sequer serem punidos pela ineficiência das autoridades nas redes sociais

Não aceitar os conceitos, forma de ritualizar o sagrado e seus desdobramentos, atacando as ideias, a moral, a ética de outras religiões ou a falta delas, procurando destruir tudo que tenha relação com pensamentos 
religiosos diferentes. O Terreiro que dirigimos no Rio de Janeiro não sofreu até agora nenhum processo de Intolerância, no entanto, Minha Mãe de Santo foi ofendida na Internet. A intolerância é discutida, dentre outros temas de envolvimento político ou social. $\mathrm{O}$ racismo institucionalizado e estrutural cria uma forma de ser e viver racista e intolerante em todas as esferas de pensamento. Essa intolerância religiosa começa com o Estado ligado intimamente com a Igreja Católica e migra, nos últimos anos, para as Igrejas Protestantes Neopentecostais. Temos apoiado nossos Companheiros de outros Templos presencialmente nos atos de protestos, via internet compartilhando essas notícias com os devidos comentários bem como participando das marchas contra a intolerância que acho que devia ser nomeada como marchas a favor do Respeito a toda forma de pensar e contra o racismo e seus desdobramentos. Há conhecimento sobre as associações e federações e as ações para combate à intolerância religiosa? As associações e federações tem se pronunciado de maneira muito discreta a respeito desses atos criminosos, com exceção do MIRUA cuja página se encontra no Facebook e da comissão contra a intolerância religiosa. Com relação a outros estados, além das notícias de invasões e destruições de Terreiro de matriz Afro-indígena, não sabemos que providências foram tomadas. Nota: Dirijo a Choupana do Caboclo Senhor 7 Montanhas desde dezembro de 1999 que fica em Maricá e ao mesmo tempo sou Médium da OICD (Ordem Iniciática do Cruzeiro Divino) em São Paulo desde 1989 (ENTREVISTADO L, 2020).

\title{
Os entrevistados apresentam conhecimentos sobre ações de combate à
}

\section{intolerância religiosa no Brasil. Eles mencionam ações principalmente fora do}

\author{
município de Juiz de Fora, conforme exemplificado abaixo
}

Sim, em outros estados como Rio de Janeiro, São Paulo e Paraná, as associações e federações são mais atuantes dentro do contexto religioso afro, onde os mesmos, atuam nas denúncias de racismo e intolerância religiosa e auxiliando os terreiros a continuarem com os seus rituais dentro do espaço urbano (ENTREVISTADO E, 2020).

Desconheço ações de combate à intolerância religiosa em Juiz de Fora. No entanto, em vários estados brasileiros existem atividades voltados a essa temática. Como exemplo, vou citar o Advogado Hédio Silva Júnior. Ele é coordenador do IDAFRO (Instituto de Defesa dos Direitos das Religiões Afro-Brasileiras) e esse instituto tem como finalidade, dentre outras questões que envolvem nossa Religião, orientar os Terreiros nas ações de intolerância religiosa e garantir efetivamente nosso direito constitucional de liberdade de culto. Temos também a Caminhada contra a Intolerância Religiosa que acontece todo ano na cidade do Rio de Janeiro e em outras cidades do Brasil. Esse evento fomenta a importância da construção de um diálogo inter-religioso para que possamos conviver com respeito (ENTREVISTADA G, 2020).

Com relação às ações, em todo o Brasil são realizadas marchas de combate à intolerância religiosa, é... eventos, né? O CEAP, que é um grupo de Rio de Janeiro, faz sempre eventos. Eu já fui até convidada para palestrar em um deles. Também para discutir a intolerância religiosa, publicaram um livro, um relatório que eles realizaram de levantamento de casos de intolerância religiosa e, em Juiz de Fora, além dessa audiência pública que eu citei, o MNU também faz a discussão, faz o Feijão do Ogum 
que é um evento no qual sempre se discute a temática da intolerância religiosa. Em novembro também, que é o mês da consciência negra, também são realizados alguns eventos também no qual esse tema costuma ser discutido (ENTREVISTADA H, 2020).

Apenas a Entrevistada I afirmou conhecer ações de combate à intolerância no município

Conheço vários militantes que estão no combate a intolerância religiosa, tanto em Juiz de Fora, quanto em outras cidades. O Babalaô Ivanir dos Santos é uma grande referência que sempre assisto os conteúdos (ENTREVISTADA I, 2020).

O Entrevistado $\mathrm{F}$ demonstrou acompanhar o caso da mãe que perdeu a guarda judicial da filha devido à participação desta no ritual de iniciação no Candomblé

\begin{abstract}
Acompanhamos todos os casos que acontecem em Minas e no Brasil através das parcerias e noticiários, a exemplo da mãe que perdeu a guarda da filha - ambas de religião de matriz africana, para a avó evangélica, com o apoio do Conselho Tutelar e da Polícia Civil. Caso no Rio de Janeiro que o prefeito da cidade onde está localizado a Comunidade-Terreiro do Tateto Joãozinho da Goméia, que queria derrubar o sítio em tombamento e foi barrado pelos defensores da manutenção do local sagrado, entre outros (ENTREVISTADO F, 2020).
\end{abstract}

É neste ponto e a partir dos discursos dos entrevistados que é possível entender a importância do esforço de se normatizar, decodificar, legitimar e racionalizar as práticas das religiões de matriz africana através das federações (NEGRÃO, 1996). A despeito de não existirem federações unificadoras dominantes, como já exposto, as federações são essenciais à organização e desenvolvimento de tais religiões, seja através da assistência de suas religiões afiliadas, especialmente no que se refere à regulamentações de práticas rituais e doutrinárias, seja através da fiscalização e assistência jurídica contra a perseguição e organização (SILVA, 2005).

As notícias sobre os ataques intolerantes, mesmo em meio à pandemia, não cessaram e até foram motivos de matérias jornalísticas nas principais mídias 
televisivas. O caso da mãe que perdeu a guarda da filha por estar na iniciação do Candomblé ${ }^{36}$ demonstra o racismo religioso escancarado e o racismo estrutural da sociedade brasileira e do Judiciário Brasileiro e sua estrutura voltada para proselitistas e oportunistas pró-pautas da direita histérica e do fundamentalismo religioso cristão.

No Brasil, vivemos um misto de máfia miliciana no poder, somado a fanáticos religiosos, que dizem ser atacados e usam e abusam das estruturas do Estado para justificar o proselitismo religioso e impor a ditadura cristã a qualquer preço.

O atual presidente da Fundação Palmares ${ }^{37}$ expõe todo o seu ódio religioso com frases repletas de demonização e de termos depreciativos aos afro-religiosos. O ataque direto a uma lalorixá demonstra a postura dele e do atual Governo Federal com as comunidades tradicionais de terreiro. O cenário de terra arrasada, ou seja, a não disponibilização de verbas para as comunidades de terreiro, deixa claro a intenção dessa gestão de uma necropolítica como afirma Mbembe (2018).

A elitização da sociedade e a exclusão do povo da participação da sociedade pelos conservadores está massacrando a população e aumentando as vítimas da necropolítica (MBEMBE, 2018).

A autorização dos desvarios dos proselitistas está tornando o cotidiano dos praticantes das religiões de comunidades tradicionais de terreiro uma constante problematização e conflitos que extravasam na imprensa com conotações que não ajudam a melhorar o cenário, acabam informando, para o deleite dos fanáticos as

36 Disponível em: <https://www.hypeness.com.br/2020/08/racismo-religioso-faz-mae-perder-guarda-da-filhaapos-participar-de-sessao-de-candomble/

https://www.cartacapital.com.br/sociedade/o-desabafo-da-mae-que-perdeu-a-guarda-da-filha-por-participar-deritual-de-candomble-so-choro-esperando-ela-voltar/

https://revistaforum.com.br/movimentos/mae-recupera-a-guarda-da-filha-retirada-pelo-conselho-tutelar-porparticipar-de-ritual-de-candomble/>

37 Disponível em: <https://noticias.uol.com.br/cotidiano/ultimas-noticias/2020/06/04/mae-de-santo-racismoreligioso-fundacao-palmares.htm> 
suas conquistas $^{38}$. A imprensa deve informar e, principalmente, retirar a depreciação das religiões afro-brasileiras e escancarar a faceta do racismo brasileiro encarnada no racismo religioso assíduo contra a fé dos afro-religiosos.

Entretanto, como aplicar leis duras aos fanáticos, se eles estão no poder? Um deles atua livremente e impunimente pelos corredores do poder e está poderoso, dando unção ao atual presidente e promovendo o seu conglomerado da fé ao poder de uma importante cidade e sendo aceito pela população local como um excelente político e que cuida bem da população da cidade, nem que para isso precise de "guardiões" para defendê-lo39.

O que eles esquecem é que, mesmo no poder, não calarão os tambores e não cessarão as festas. A festa, a confraternização e a diversão já fazem parte da alma brasileira, os terreiros não funcionam como esquemas de lavagem de dinheiro sujo, como escreve Sodré

O contra-espaço é um lugar de não-poder branco, mas que admite o contato, o acerto, desde que não implicasse alguma forma de poder direto sobre a comunidade negra. Intelectuais prestigiados ou em ascensão (Manuel Bandeira, Rubem Braga, João do Rio) e políticos consagrados frequentavam a casa da Tia Ciata ou então escreviam sobre as festas e cultos negros do Rio (SODRÉ, 1988, p. 141).

A cosmovisão negra rompe com o padrão cartesiano de vida e da imposição do "aceita Jesus" dos proselitistas que querem que aceite o Jesus e em troca pague o pedágio para o pastor que cobra muito mais que o dízimo. Sodré informa sobre o

\footnotetext{
${ }^{38}$ Disponível em: $<$ https://www.geledes.org.br/funcionaria-denuncia-empresa-por-demissao-depois-de-raspar-acabeca-em-ritual-religioso-em-cuiaba-e-diz-que-foi-chamada-de-macumbeira/

http://atarde.uol.com.br/portalmunicipios/metropolitana/noticias/2132123-mae-de-santo-denuncia-servidores-daprefeitura-de-lauro-de-freitas-por-intolerancia-religiosa

https://www.tribunapr.com.br/noticias/curitiba-regiao/terreiro-na-regiao-de-curitiba-sofre-ataque-racista-seulugar-e-na-senzala/

https://www.diariodepernambuco.com.br/noticia/vidaurbana/2020/08/sacerdote-da-jurema-denuncia-racismoreligioso-em-olinda.html>

39 Disponível em: <https://g1.globo.com/rj/rio-de-janeiro/noticia/2020/09/01/guardioes-do-crivella-entenda-asdenuncias-sobre-esquema-para-impedir-reportagens-sobre-a-saude-no-rio.ghtml>
} 
indivíduo total que a cosmovisão negra possibilita e não um homem subjugado pela vontade de ditadores e corruptos da fé

Na cosmovisão negra, porém, a ação regula-se pelo padrão do indivíduo total, ou seja, de um sujeito articulado consigo mesmo e com os outros em comunidade. $\mathrm{O}$ que diz a esse sujeito, a intuição de mundo negra é que o jogo, mesmo fora, do poder, tem a força de promover uma certa integração da existência, a exemplo de instancia, quase orgânica, da vida (SODRÉ, $1988,143)$.

\section{CONSIDERAÇÕES FINAIS}

O cenário de terra arrasada promovido pelas atuais gestões conservadoras e apoiadas por líderes proselitistas consolidadas pelo racismo estrutural, contribui para uma geração de destruidores, desrespeitadores e fanatizados pelos termos, sou conservador, cristão, a favor da família, contra a corrupção, patriota, "cidadão de bem", enfim, a tábula rasa dos termos não altera a natureza misógina, racista, intolerante e fascista de uma estrutura destinada a destruir direitos sociais e garantias fundamentais de qualquer cidadão. Aliás, o cidadão brasileiro não existe, existe o cidadão Engenheiro (a), Médico (a), Juiz (a), Militares, Políticos, enfim, corporações que assumiram o poder e o distribuem conforme a vontade dos apadrinhados e beneficiários de um sistema que garante o genocídio da população negra e dos indígenas, o vilipêndio dos direitos dos trabalhadores e dos que não vivem sob as estruturas corporativas e milicianas que ditam as regras de uma destruição, sem precedentes na História do Brasil.

Contudo, autoproclamam-se salvadores, restauradores ou condutores de uma Nova Ordem Nacional, o que chamo de ordem do caos intencional e de um projeto de destruição programado e da Nação e dos direitos que, ainda, existem.

As comunidades tradicionais de terreiro sobrevivem em meio ao cenário de destruição, conduzindo e melhorando a vida de cada qual que a procura para 
equilibrar-se, mesmo, em meio ao caos vigente nesse País que agoniza neste período de pandemia, com muitas vítimas e de descaso com a proteção à saúde, alimentação, emprego, enfim, dos direitos humanos básicos.

O poder do genocídio e da morte reinam no Brasil e a resposta, mesmo que tímida e não veiculada pelas mídias hegemônicas do País, é a existência e a resistência das tradições de terreiro e seu modo peculiar de viver conforme o auxílio da natureza, buscando nela, o equilíbrio e a qualidade de vida que a maioria quer, demonstrado ser uma religião que promove a natureza e ajuda em sua conservação.

Nas religiões de tradição de terreiro a vida deve ser vivida em sua plenitude, e a vida é reverenciada nas festas e nas reuniões que tem como objetivo as saudações aos orixás e das entidades que organizam o ser e o equilibram. $O$ contexto da pandemia, trouxe o isolamento e a dificuldade de reunir e festejar a vida. Mas, as redes sociais e a internet possibilitam o autoconhecimento e consultas a oráculos e videntes de forma remota e a orientação desta maneira está atingindo mais e mais pessoas não só no Brasil e, também, em outros países, proporcionando um maior conhecimento e divulgação dos benefícios das terapias e ebós para diferentes finalidades e gostos pessoais.

Os ataques intolerantes não cessaram, a paz e a tranquilidade para os que pertencem ao povo de santo não são oferecidas, muitos dos entrevistados consideram-na uma conquista e uma forma de demonstrar a sua fé nos orixás e nas entidades afro-ameríndias, independente da demonização e da exclusão causadas pela política genocida vigente no País e dos seguidores fanatizados de líderes proselitistas interessados em enriquecer às custas das benesses governamentais, leis que garantem o sigilo e tranquilidade na lavagem de dinheiro, contravenções e tráfico, que associam-se a esses líderes que propagandeiam um deus personalizado 
e distante dos problemas e das mazelas dessa sociedade racista e incentivadora da morte.

A organização e a melhoria da comunicação dos afro-religiosos estão sendo fundamentais nesses tempos de descaso e abandono intencionais dos atuais gestores da política genocida oficializada após as eleições de 2018. A sensação de destruição e de fim das religiões de tradição de terreiro já não é vista como um horizonte conquistado pelos fanatizados, seus líderes e políticos representantes da gestão da morte, que administram o caos e comemoram as conquistas de vilipendio e de retiradas de direitos, chamando-as de "fim das mamatas". Contudo, a população, já está acordando para a necessidade de união e de enfrentamento das dificuldades, pois, caso não se organizasse e mobilizasse, mesmo remotamente, não teríamos um Sistema de Saúde Público, ele já séria, aos poucos entregues à iniciativa privada e aos interesses dos donos de planos de saúde. Os números de casos e de mortes pela pandemia seriam maiores e auxílios emergenciais que beneficiaram, mesmo que pouco, por pouco tempo, não atingiriam os brasileiros e brasileiras que acreditaram nas mentiras e informações falsas plantadas pela mídia hegemônica, promotoras de um discurso falso de eficiência e de mérito que perpetuam a colonialidade e o poder embranquecido e racista. Mesmo, que esse poder branco venha de um lixo humano enaltecido pelos fanatizados seguidores que comprazem de um discurso de ódio e que favorecem a expansão da visão limitadora e destruidora da nação, por um projeto de desqualificação dos direitos humanos e de destruição das garantias individuais, para oferecer ao povo esmolas e migalhas do que sobram dos banquetes das minorias abastadas e indiferentes ao projeto de nação para todos, e sim de uma perpetuação de seu padrão de poder embranquecido, machista e destruidor. 
Os números da pandemia são assustadores, mas o que mais incomoda e o descaso com a vida e o descompromisso com a saúde da população e de um sistemático sentido de destruição da nação. $O$ alento está na fé afro-brasileira que renova a esperança de uma melhoria do quadro da saúde, da estabilidade financeira e da vida digna para os que acreditam no axé e firmam os pontos e cantam para as entidades protegerem e fortalecerem a vida.

O racismo religioso deve ser encarado como fator primordial para os atos extremados contra as religiões afro-brasileiras, bem como a constância dos ataques. Não é uma questão de tolerar a religiosidade das comunidades tradicionais de terreiro. É fundamental o respeito as religiões que já pertencem ao cotidiano e resistem mesmo diante desse quadro de racismo escancarado na sociedade brasileira.

A intolerância religiosa, termo muito usado pelo mundo midiático e pelo meio jurídico, deverá introduzir o termo, racismo religioso, pois a opressão e a continuidade dos ataques racistas denotam uma sistemática opressão ao povo de santo, que culmina na diminuição de sua autodeclaração como afro religioso.

O respeito às minorias religiosas é constitucional e é um direito do cidadão. Os cidadãos também possuem o direito de sequer ter religião, o que tem provocado um aumento dos ateus e daqueles que declaram não ter religiões, dada ao avanço proselitista e de diminuição de liberdades ou mudanças sociais dada as intervenções da Bancada Evangélica e dos setores conservadores da sociedade brasileira que retrocedem as conquistas sociais e não desejam a modernização da sociedade e o respeito as minorias, mulheres, aos diferentes e aos desamparados.

As vítimas do genocídio negro só aumentam e transformam a realidade dos mais carentes em uma terra arrasada e promovem em realidade as fantasias dos 
piores tipos de seres humanos que já ocuparam o poder no Brasil: torturadores, milicianos, burocratas, proselitistas, fanáticos religiosos, madeireiros, garimpeiros, grileiros, latifundiários, falsos profetas, enfim, a escória da humanidade governa o Brasil e transformam-no em cinzas. Porém, tudo planejado e calculado, assim como os ataques racistas aos praticantes da fé afro-brasileira, devem ser punidos com rigor, as leis devem ser duras aos que promovem atos covardes de invasões de terreiros e a destruição deles.

Após essa leitura das comunidades de terreiro, entendo o silêncio de muitos sobre a não resposta aos questionamentos de racismo religioso e dos ataques dos intolerantes. O segredo da força de resistência das religiões afro-brasileiras está no silêncio, na vida comunitária e, sobretudo, na organização dos mais jovens e no respectivo modo de agir nas redes sociais e nas fotos com trajes iniciáticos, expondo em seus perfis à alegria de pertencer à religiosidade da festa, do uso correto dos recursos naturais, da saúde e da alma brasileira.

O povo de santo está consciente dos problemas enfrentados e da melhor maneira de encará-los, buscando os direitos e a Justiça, o embate, não é uma forma de angariar mais fiéis e sim de demonstrar a credibilidade das práticas religiosas e das autoridades religiosas afro-brasileiras. As federações e associações de defesa demonstram uma luta continua pelo direito de liberdade religiosa e organização, apesar da aparente timidez, diante da ferocidade dos agressores, tem sido uma ajuda nesse momento de isolamento e de descaso governamental. Enfim, os praticantes das tradições de terreiro, buscam explicar e utilizar da natureza, mas sem diminuir a importância da ciência na busca de uma solução para os problemas de saúde. Quem nega a ciência e a minimiza os efeitos da pandemia são os 
governantes e os líderes proselitistas enganadores que usam e abusam dos charlatanismos tão evidenciados até pela mídia hegemônica nacional.

Após a pandemia acredito que mais caminhadas ou passeatas demonstrarão o grau de articulação das religiões afro-brasileiras, federações, associações de combate à intolerância religiosa e movimento negro. Todos esses atores sociais e suas demandas reprimidas pelo racismo. A luta antirracista crescerá e marcará uma etapa de lutas pelo retorno de uma democracia mais participativa e mais igualitária. 


\section{REFERÊNCIAS BIBLIOGRÁFICAS}

AMARAL, Rita. Xirê! 0 modo de crer e viver no candomblé. Rio de Janeiro: Pallas; São Paulo: EDUC, 2005. 119 p.

BARROCO, Maria Lucia S. Reflexões sobre liberdade e (in)tolerância. São Paulo, Serv. Soc., v. 119, p 468-481. 2014.

BASTIDE, Roger. As religiões africanas no Brasil. São Paulo: 1989

BATISTA, Milena Xibile. ANGOLA, JEJE E KETU: Memórias e identidades em casas e nações de candomblé na Região Metropolitana da Grande Vitória (ES). 2014. 245 p. Dissertação (Mestrado em Ciências Sociais), Universidade Federal do Espírito Santo. 2014.

BAUER, Martin; GASKELL, George. Pesquisa Qualitativa com texto, imagem e som: um manual prático. Petrópolis: Vozes, 2017. 508 p.

BENTO, Maria Aparecida Silva. Branqueamento e Branquitude no Brasil. In: CARONE, Maria Aparecida Silva; BENTO, Iray. (Org.). Psicologia social do racismo: estudos sobre branquitude e branqueamento no Brasil. Petrópolis: Vozes, 2002. p. $25-58$.

BERGER, Peter L. Os Múltiplos Altares da Modernidade: rumo a um paradigma da religião numa época pluralista. Editora Vozes. Petrópolis - RJ. 2017.

BIRMAN, Patrícia. O que é umbanda. 2. ed. São Paulo: Brasiliense, 1985. 108 p. . Fazendo estilo criando gêneros. Rio de Janeiro: EDUERJ, 1995.

CAMPOS, Isabel Soares; RUBERT, Rosane Aparecida. Religiões de Matriz Africana e a Intolerância Religiosa. Londrina: Cadernos LEPAARQ, v. 11, n. 22, p. 294-307. 2014.

DANTAS, Beatriz Góes. Repensando a pureza Nagô. Rio de Janeiro, Religião e Sociedade, n. 8, p. 15-20. 1982.

DESLANDES, Suely Ferreira. Pesquisa Social: teoria, método e criatividade. In: DESLANDES, Suely Ferreira; GOMES, Romeu; Minayo, Maria Cecília de Souza. Pesquisa Social: teoria, método e criatividade. Petrópolis: Editora Vozes. 2013.cap. 2, p. 31-60.

DIANA, Brown; CONCONE, Maria Helena Vilas Boas; NEGRÃO, Lísias; BIRMAN, Patrícia e outros. Umbanda e Política. Rio de Janeiro: ISER, [S.I: s.n.], 1985.

ESTRAMIANA, José Luís Álvaro.; SEVERIANO, Maria de Fátima Vieira. Bases psicossociais da (in) tolerância: reflexões políticas. Revista Psicologia Política, p. 15-38, 2003. 
FERNANDES, Nathalia Vince Esgalha. A raiz do pensamento colonial na intolerância religiosa contra religiões de matriz africana. Revista Calundu, v. 1, n. 1. 2017.

FLORIANO, Maria da Graça. Religiões de Matriz Africana em Juiz de Fora: trajetórias, alianças e conflitos. 2009. Tese (Doutorado em Ciência da Religião) Universidade Federal de Juiz de Fora, Juiz de Fora, 2009.

GONÇALVES, Antônio Giovanni Boaes; OLIVEIRA, Rosalira dos Santos. Identidade, tradição e legitimidade afro-brasileiras. Recife: Religiosidades populares, diálogos e interpretações. p. 125-140. 2011.

KILEUY, Odé; OXAGUIÃ, Vera de. O candomblé bem explicado (Nações Bantu, lorubá e Fon). Rio de Janeiro: Editora Pallas. 2009. 554 p.

LANE, Silvia T. M.; CODO, Wanderley. Psicologia Social: o homem em movimento. São Paulo: Brasiliense, 2004. 221 p.

LOCKE, John. Carta acerca da Tolerância: Segundo tratado sobre o governo: Ensaio acerca do entendimento humano. São Paulo: Abril Cultural, 1983.

MACEDO, Bispo. Orixás, caboclos e guias: deuses ou demônios? 18. ed. Rio de Janeiro: Editora Unipro. 2016.

MARIANO, Ricardo. Guerra Espiritual: o protagonismo do diabo nos cultos neopentecostais. Porto Alegre, Debates do NER. n. 4, p. 21-34. 2003.

MARIZ, Cecília Loreto. Reflexões sobre a Reação Afro-Brasileira à Guerra Santa. Porto Alegre, Debates do NER., n. 1, p. 96-103. 1997.

MBEMBE, Achille. Necropolítica: biopoder, soberania e estado exceção, política de morte. N1 edições. 2018.

MORAIS, Mariana Ramos de. Políticas Públicas e a fé afro-brasileira: uma reflexão sobre as ações de um Estado laico. Porto Alegre, Ciências Sociais e Religião, n. 16, p. 39-59. 2012.

Nas teias do sagrado: registros da religiosidade afro-brasileira em Belo Horizonte. Editora Espaço Ampliar, 2010. 123 p.

MOURA, Carlos Eugênio Marcondes. Candomblé - Religião do corpo e da alma. Rio de Janeiro: Pallas: 2000.

NEGRÃO, Lísias N. Magia e Religião na Umbanda. São Paulo, Revista USP, n. 31, p. 76-89, 1996.

. A umbanda como expressão de religiosidade popular. Religião e Sociedade, n. 4, p. 171-190, 1979.

. Entre a cruz e a encruzilhada. São Paulo: Edusp, 1996.

OLIVEIRA, Ariadne Moreira Basílio. Religiões Afro-brasileiras e o racismo: contribuição para a categorização do racismo religioso. 2017. 104 p. 
Dissertação (Mestrado em Direitos Humanos e Cidadania), Universidade de Brasília. 2017.

ORO, Ari Pedro. "As religiões afro-brasileiras: religiões de exportação". In: ORO, Ari Pedro (org.). As religiões afro-brasileiras no Cone Sul. Porto Alegre: Cadernos de Antropologia. 1993.

. Neopentecostais e afro-brasileiros: quem vencerá esta guerra? Debates do NER, v. 1, n. 11997.

Intolerância Religiosa lurdiana e Reações Afro no Rio Grande do Sul. In: SILVA, V. G. (Org.). Intolerância Religiosa: Impactos do Neopentecostalismo no Campo Religioso Afro-Brasileiro. São Paulo: EDUSP, 2007. p. 29-69,

. Religiões Afro-Brasileiras do Rio Grande do Sul: Passado e Presente. Revista Estudos Afro-Asiáticos, n. 2, p. 345-384. 2002.

ORTIZ, Renato. A morte branca do feiticeiro negro. 2. ed. São Paulo: Brasiliense, 1999.

Ética, poder e política: umbanda, um mito-ideologia. Rio de Janeiro, Religião e Sociedade, n. 11, p. 36-53. 1984.

PRANDI, Reginaldo. O Brasil com axé: candomblé e umbanda no mercado religioso. São Paulo, Estud. av.[online], v. 18, n. 52, p .223-238. 2004.

Herdeiras do Axé. São Paulo: Hucitec,1996. 199 p.

Mitologia dos Orixás. São Paulo: Companhia das Letras, 2001. 591 p.

De africano a afro-brasileiro: etnia, identidade, religião. São Paulo, Revista USP, n. 46, p. 52-65. 2000.

Referências Sociais das Religiões Afro-Brasileiras: sincretismo, branqueamento e africanização. Porto Alegre, Revista Horizontes Antropológicos, n. 4, p. 151-167. 1998.

Segredos Guardados: orixás na alma brasileira. São Paulo: Companhia das Letras, 2005. 328 p.

PRANDI, Reginaldo; Jácomo, Luiz; Bernardo, Teresinha. Trinta Anos Depois: Realidade E Pesquisa Das Religiões Afro-Brasileiras Do centenário Da Abolição Aos Dias De Hoje (1988-2018). São Paulo, Revista USP, v. 122, p. 99-120. 2019.

QUEIROZ, Maria Isaura Pereira de. Identidade Cultural, Identidade Nacional no Brasil. São Paulo, Tempo Social - Revista de Sociologia da USP, v. 1, n. 1, p. 2946. 1989.

RIBEIRO, Djamila. Pequeno Manual Antirracista. 1. ed. São Paulo. Companhia das Letras, 2019. 69 p.

SAMPAIO, Dilaine Soares. "A manifestação de religiosidade não contém traços de uma religião": uma análise das relações entre Poder Judiciário e religiões afrobrasileiras. Caicó, Dossiê Religiões Afro-brasileiras, v. 15, n. 34, p. 54-82. 2014.

SANTOS, Ivanir. A Caminhada em Defesa da Liberdade Religiosa e seus desafios para a construção do diálogo inter-religioso. NUMEM, v. 22, p. 26-42. 2019. 
SAWAIA, Bader. As artimanhas da exclusão: análise psicossocial e ética da desigualdade social. 3. ed. Petrópolis, RJ: Vozes, 2008. 82 p.

SCANLON, Thomas M. A Dificuldade da Tolerância. Novos Estudos Cebrap. n. 84, p. 31-45. 2009.

SILVA, Sérgio Gomes da. Direitos Humanos: entre o princípio de igualdade e tolerância. Rio de Janeiro, Revista Praia Vermelha. v.19, n. 1, 79-94. 2009.

SILVA, Vagner Gonçalves. Orixás da Metrópole. Petrópolis: Vozes, 1995.

. Candomblé e Umbanda: caminhos da devoção brasileira. $2^{a}$ ed. São

Paulo: Selo Negro, 2005.

. (Org.) Intolerância Religiosa: impactos do Neopentecostalismo no Campo $\overline{R e l i g i o s o ~ A f r o-b r a s i l e i r o ~-~ 1 . ~ e d . ~ S a ̃ o ~ P a u l o: ~ U n e s p, ~ 2015 . ~} 328$ p.

SILVA, Tomaz Tadeu; HALL, Stuart; WOODWARD, Kathryn. Identidade e Diferença: a perspectiva dos Estudos Culturais. Petrópolis: Vozes, 2000.

SIMAS, Luiz Antônio \& RUFINO, Luiz. Fogo no Mato: a ciência encantada das macumbas. Editora Mórula. 2018. p 124.

SOARES, R. R. Espiritismo: a magia do engano. Rio de Janeiro: Graça Editorial. 1984.

SODRÉ, Muniz. O Terreiro e a Cidade a forma social negro-brasileira. Petrópolis: Vozes, 1988. Petrópolis: Editora Vozes. 1988.

WILLIAMS, Bernard. Tolerância: uma questão política ou moral? Novos Estudos Cebrap. n. 84, p. 47-58. 2009. 


\section{APÊNDICE A - ROTEIRO DE ENTREVISTAS}

\section{Universidade Federal de Juiz de Fora \\ Programa de Pós-Graduação em Ciência da Religião}

Pesquisa: A defesa das religiões de comunidades tradicionais de terreiro: os desafios da luta contra as formas de intolerância religiosa.

Responsável: Ronald Belinassi

Orientadora: Prof. Sônia Regina Correa Lages

I) Dados do entrevistado:

Nome:

Qual sua idade?

Qual a sua escolaridade?

Qual o nome do terreiro e a localização?

Qual seu tipo de filiação?

II) Roteiro:

Qual o tempo de existência do terreiro?

Qual seu tempo de filiação no terreiro?

O que você entende por intolerância religiosa?

Relatos de intolerância religiosa contra o terreiro, ou contra a pessoa afiliada à religião:

O tema da intolerância contra as religiões afro é discutido dentro do terreiro ou não?

$\mathrm{Na}$ sua opinião, quais as causas da intolerância contra as religiões afro e quais os setores sociais mais intolerantes com o referido campo religioso?

Quais as atitudes tomadas diante do ato de intolerância religiosa?

Há conhecimento sobre as associações e federações e as ações para combate à intolerância religiosa?

Conhecimento sobre as ações na região e no Brasil de combate à intolerância religiosa. 